\title{
Een continue zorg : een studie naar het verband tussen personeelswisselingen, organisatiekenmerken, teameffectiviteit en kwaliteit van begeleiding in residentiele instellingen voor mensen met verstandelijke beperkingen
}

Citation for published version (APA):

Buntinx, W. H. E. (2004). Een continue zorg : een studie naar het verband tussen personeelswisselingen, organisatiekenmerken, teameffectiviteit en kwaliteit van begeleiding in residentiele instellingen voor mensen met verstandelijke beperkingen. [Doctoral Thesis, Maastricht University]. Datawyse / Universitaire Pers Maastricht. https://doi.org/10.26481/dis.20041222wb

Document status and date:

Published: 01/01/2004

DOI:

$10.26481 /$ dis.20041222wb

Document Version:

Publisher's PDF, also known as Version of record

Please check the document version of this publication:

- A submitted manuscript is the version of the article upon submission and before peer-review. There can be important differences between the submitted version and the official published version of record. People interested in the research are advised to contact the author for the final version of the publication, or visit the DOI to the publisher's website.

- The final author version and the galley proof are versions of the publication after peer review.

- The final published version features the final layout of the paper including the volume, issue and page numbers.

Link to publication

\footnotetext{
General rights rights.

- You may freely distribute the URL identifying the publication in the public portal. please follow below link for the End User Agreement:

www.umlib.nl/taverne-license

Take down policy

If you believe that this document breaches copyright please contact us at:

repository@maastrichtuniversity.nl

providing details and we will investigate your claim.
}

Copyright and moral rights for the publications made accessible in the public portal are retained by the authors and/or other copyright owners and it is a condition of accessing publications that users recognise and abide by the legal requirements associated with these

- Users may download and print one copy of any publication from the public portal for the purpose of private study or research.

- You may not further distribute the material or use it for any profit-making activity or commercial gain

If the publication is distributed under the terms of Article $25 \mathrm{fa}$ of the Dutch Copyright Act, indicated by the "Taverne" license above,

Download date: 26 Apr. 2023 


\section{EEN CONTINUE ZORG}

Een studie naar het verband tussen personeelswisselingen, organisatiekenmerken, teameffectiviteit en kwaliteit van begeleiding in residentiële instellingen

voor mensen met verstandelijke beperkingen 
Een continue zorg. Een studic naar het verband tussen personeelswisselingen, organisatiekenmerken, teameffectiviteit en kwaliteit wan begeleiding in residentële instellingen voor mensen met verstandelijke beperkingen

W.H.E. Buntin:

Proefschrift Universitcit Mastrich, Maastricht, Nederland

Met samenvatring in het Lingels

ISBN 90-5278433-7

"Trefwoorden" continuiteit van zorg/kwaliteit van zorg/organisatic/teameffectiviteit verlop

\section{Wil H.E. Buntinx}

Universiteit Mastricht

Capaciteitsgroep Beleid, Economie en Organisatic wan de Zorg

Postbus 616

$6200 \mathrm{MD}$ Masstricht 


\title{
EEN CONTINUE ZORG
}

Een studie naar het verband tussen personeelswisselingen, organisatiekenmerken, teameffectiviteit en kwaliteit van begeleiding in residentiële instellingen

voor mensen met verstandelijke beperkingen

\author{
PROEFSCHRIF"T \\ ter verkrijging van de graad van doctor \\ aan de Universiteit Maastricht, \\ op gezag van de Rectot Magnificus, \\ Prof. mr. G.P.M.F. Mols \\ volgens het besluit van het College van Decanen, \\ in het openbaar te verdedigen \\ op woensdag 22 december 2004 om 16.00 uur
}

door

Willy Henri Emma Buntinx

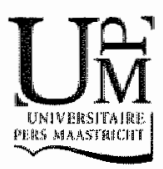




\section{Promotor:}

Prof. dr. A.Th.G. van Gennep

\section{Beoordelingscommissie}

Prof. dr. W.N.J.Groot (voorzitter)

Prof. dr. A.P. Aldenkamp

Prof. dr. B. Maes (Katholieke Universiteit Leuven, België) 


\section{INHOUDSOPGAVE}

1 INLEIDING 9

1.1 Personeelswisselingen als probleem 11

1.1.1 Residentiele instellingen voor mensen met
verstandelijke beperkingen

1.1.2 Woongroepteams in residentiële instellingen 12

1.1.3 Effectiviteit van wroongroepteams 12

1.1.4 Continuiteit, effectiviteit en kwaliteit 13

1.2 Doel en probleemstelling van de studie 14

1.3 Begripsomschrijvingen $\quad 16$

1.3.1 Kenmerken van het woongroepteam als spil van het primaire proces 16

1.3.2 'Verloop' versus 'personeelswisselingen' 18

1.3.3 'Effectiviteit' en 'kwaliteit' 19

1.3.4 'Zorg' versus 'ondersteuning' en 'begeleiding' en het

1.4 Opbouw van de studie en leeswijzer 22

Deel I

2 DE RESIDENTIËLE INSTELLING ALS ORGANISATIE: EEN HISTORISCHSOCIALE SCHETS

2.1 Van de $19^{\circ}$ eeuw tot de AWBZ 30

2.1.1 Achtergrond van de ontwikkelingen 30

2.1.2 Organisatic 33

2.2 Van 1968 tot $1990 \quad 36$

2.2.1 Achtergrond van de ontwikkelingen $\quad 36$

2.2.2 Organisatic 39

2.3 De jaren negentig en de periode 2000 tot 2003

2.3.1 Achtergronden van ontwikkeling 41

2.3.2 Organisatie 46

2.4. Personeelswisselingen in historisch perspectief 51

2.5 Residentiële instellingen: de huidige Nederlandse situatic 53

3 PersoneELsWisselingen

3.1 Personeelswisselingen als praktijkprobleem 59

3.1.1 Het perspectief van de bewoner 59

3.1.2 Het perspectief van ouders en familie 60 
3.1.3 Het perspectief van professionals en brancheorganisatie $\quad 60$

3.1.4 Conclusie 61

3.2 Personeelswisselingen als wetenschappelijk probleem 62

3.2.1 Verband tussen personeelswisselingen en teameffectiviteit 62

3.2.2 Verband tussen 'verloop' of 'personeelswisselingen' en 'kwaliteit van zorg' 65

3.2.3 Correlaten van verloop en personeelswisselingen 68

3.2.4 Het meten van personeelswisselingen 73

$\begin{array}{ll}3.2 .5 \text { Conclusie } & 75\end{array}$

4 TEAMEFFECTVITETT EN KWALITEIT

4.1 De dienstenorganisatie en de effectiviteit van het teamfunctioneren

$\begin{array}{lll}4.1 .1 & \text { Dienstenorganisaties } & 79\end{array}$

4.1.2 De vraaggerichte dienstenorganisatie $\quad 80$

4.1.3 Wie is de cliënt? 82

4.1.4 Cliëntgerichtheid en marketing 84

4.1.5 Cliënttevredenheid en kwaliteit 88

4.1.6 Teameffectiviteit en cliënttevredenheid in
marketingstudies

4.2 De dienstenorganisatie en kwaliteitszorg $\quad 91$

4.2.1 Facetten van kwaliteit $\quad 92$

4.2.2 Aandacht voor kwaliteit in de loop van de tijd 96

$\begin{array}{ll}4.2 .3 \text { Indicatoren, modellen en systemen } & 97\end{array}$

$\begin{array}{ll}4.2 .4 & \text { Continuiteit en kwaliteit } \\ & 102\end{array}$

5 CONCLUSIE LITERATUURSTUDIE EN FORMULERING ONDERZOEKSVRAGEN

$\begin{array}{lll}5.1 \text { Conclusie deel I } & 107\end{array}$

$\begin{array}{ll}5.2 \text { Onderzoeksvragen } & 109\end{array}$

\section{DEEL II}

6 THEORETISCH KADER

6.1 Verstandelijke beperkingen en omgeving

6.1.1 'Handicap': een functionele visie

6.1.2 Verstandelijke beperkingen en omgeving

6.1 .3 Het ecologisch karakter van ondersteuning 
6.2 De sociale ecologie

6.2.1 Conceptualisering ran de ondersteuningsomgeving $\quad 123$

6.2.2 Voorwaarden voor gunstige interacties 126

$\begin{array}{ll}6.3 \text { Organisatietheorie } & 128\end{array}$

6.3.1 Funcrioneren van het dienstenteam $\quad 128$

6.3.2 Het meten van cliënttevredenheid $\quad 131$

6.4 De onderzocksvragen binnen de theoretische context 136

7 OPZET VAN HET ONDERZOEK

7.1 Doelstelling en onderzoeksvragen 141

$\begin{array}{ll}7.2 \text { Onderzoeksgroep } & 142\end{array}$

7.3 Methode 144

7.4 Operationalisering van de onderzoeksvariabelen en gebruikte meetinstrumenten

7.4.1 Personeelswisselingen

7.4.2 Woongroepkenmerken

7.4.3 Teameffectiviteit

7.4.4 Ervaren kwaliteit van begeleiding

7.5 Procedure

7.6 Data analyse 152

7.7 Geoperationaliseerde onderzoeksvagen 153

8.1.1 Medewerkers

8.1.2 Familie

8.1.3 Bias

8.2. Uitkomsten van de drie maten 'personeelswisselingen' (PW)

8.3 Onderzoeksvraag 1: verband russen personeelswisselingen en woongroepkenmerken

8.4 Onderzoeksvraag 2: verband tussen personeelswisselingen on teameffectiviteit

8.5 Onderzoeksvragg 3: verband tussen personeelswisselingen en door familie ervaren $k$ waliteit van begeleiding

8.6. Onderzoeksvraag 4: verband tussen teamfunctioneren en door familie ervaren kwaliteit wan begeleiding

8.7 Onderzoeksvraag 5: personeelswisselingen en het verband tussen teameffectiviteit en door familie ervaren kwalireit van begeleiding 
8.8 Onderzoeksvraag 6: bijdrage van de gecombineerde variabelen organisatiekenmerken, personeelswisselingen en

teameffectiviteit aan de voorspelling van 'ervaren kwaliteit van begeleiding'

8.9 Samenvatring van de resultaten

9 CONClUSIE, DISCUSSIE EN AANBEVELINGEN

9.1 Conclusies 181

9.2 Discussie 186

9.2.1 Methodologische beschouwingen 186

9.2.2 Inhoudelijke beschouwingen 187

9.2 .3 Wetenschappelijke beschouwingen 189

9.3 Aanbevelingen 190

9.3.1 Aanbevelingen in het kader van kwaliteitsbeleid $\quad 190$

9.3.2 Aanbevelingen voor strategisch management 192

LITERATUUR

SAMENVATTING

SUMMARY

BIJLAGEN

Bijlagen bij hoofdstuk 2

Bijlagen bij hoofdstuk 3

Bijlagen bij hoofdstuk 6

Bijlagen bij hoofdstuk 7

250

Bijlagen bij hoofdstuk 8

DANKWOORD 


\section{Inleiding}



Deze studie handelt over wisselingen van groepsleiders in woongroepteams van Nederlandse residentiële instellingen voor mensen met verstandelijke bepetkingen. Frequente personeelswisselingen binnen een woongtoepteam worden algemeen beschouwd als een risico voor de kwaliteit van de geleverde begeleiding. In deze studie wordt verslag gedaan van zowel een literatuurstudie als een empirisch onderzoek naar de organisatorische context van personeelswisselingen, naar cle ant en omvang van deze wisselingen, en naar de samenhang van personeelswisselingen met teameffectiviteit en met kwaliteit van geleverde begeleiding. Deze inleiding begint met een korte beschrijving van het terrein en de aanleidingen voor de studie (paragraaf 1.1). Vervolgens worden het doel en de probleemstelling geformuleerd (paragraaf 1.2). Dan volgt de omschrijving van een atantal belangrijke begrippen in deze studie (paragraaf 1.3). Het inleidend hoofdstuk wordt afgesloten met de formulering van voorlopige onderzoeksvragen, een overzicht van de opbouw van de studie en met een leeswijzer (paragraaf 1.4).

\subsection{Personeelswisselingen als probleem}

\subsubsection{Residentiële instellingen voor mensen met verstandelijke beperkingen}

Volgens de meest recente wetenschappelijke schatring bedragt de prevalentie van mensen met verstandelijke beperkingen per 1 januari 2001 in de Nederlandse bevolking 0,669 procent. In absolute cijfers gaat het om 111.750 mensen (Van Schrojenstein Lantman-deValk, Van Heurn-Nijsten \& Wullink, 2002). Ongeveer de helft woont thuis bij ouders, bij familie, in een pleeggezin of zelfstandig. De andere helft woont in centra voor begeleid wonen ('gezinsvervangende tehuizen") of in instellingen; dit zijn beide voorzieningen op grond van de Algemene Wet Bijzondere Ziektekosten (AWBZ). Er maken 18.175 bewoners gebruik van centra voor begeleid wonen en 35.984 bewoners van residentiële instellingen. Het grootste deel van de instellingscapaciteit (33.694) berteft 133 'Algemene Instellingen voot Verstandelijk gehandicapten'(AIV), wartoe ook de acht instellingen voor meervoudig gehandicapten worden gerekend (Eggink \& Blank, 2001; College Tarieven Gezondheidszorg, 2002).

AIV's bieden ' 7 x. 24 uur' zorg aan mensen met verstandelijke beperkingen van alle leefujden en alle niveaus van zorgintensiteit. De zorg strekt zich hien uir over verschillende AWBZ-functies waronder huishoudelijke en persoonlijke verzorging, verpleging, ondersteunende en activerende begeleiding, behandeling en verblijf. Omdat in algemene instellingen de woonfunctie centraal staat en de overige functies overwegend binnen dezelfde organisatie en vaak op dezelfde locatie worden geleverd, wordt ook gesproken over residentüle instellingen. Residentële instellingen zijn een vorm van langdurige zorg; de gemiddelde verblijfsduur van de huidige cliënten bedraagt achttien jaar (Vereniging Gehandicaptenzorg Nederland, 2002). Deze studie gaat over de begeleiding binnen de woonfunctie vatn residentiele instellingen voor mensen met verstandelijke beperkingen (ATV). 


\subsubsection{Woongroepteams in residentiële instellingen}

Onder invloed van een veranderende zorgvisie zijn residentële instellingen de laarste tien jaren sterk in beweging. Dit belet niet dat het meest voorkomende organisatiepatroon van de woonfunctic in residentiele instellingen tot op heden nog steeds de 'woongtoep' is. Een woongroep bestaat gemiddeld uit negen tot tien bewoners (Vereniging Gehandicaptenzorg Nederland, 2002). Aan een woongroep zijn een aantal professionele begeleiders verbonden: de groepsleiders. Dezen werken in teamverband. De koppeling tussen woongtoep en woongroepteam is in Nederland nog steeds het overheersende organisatiepatroon. De omvang en samenstelling van dit woongrocpteam en de inzet van groepsleiders over de verschillende dagen van de week worden afgestemd op de zorgvragen en de zorgintensiteit van de bewoners. In het kader wan individualisering van zorg heeft een cliënt van een residentiele instelling sinds de jaren negentig ook te maken met een 'persoonlijke begeleider' die de begeleiding rond een bepaalde bewoner coördineert. Een persoonlijke begeleider is meestal een lid van het woongroepteam maar deze koppeling wordt in sommige instellingen bewust niet gemaakt (Van Loon, 2001). Een "persoonlijk begeleider' verricht coördinerende taken, meestal voor meerdere bewoners. De dagelijkse praktische begeleiding komt echter voor rekening van alle teamleden samen en is niet beperkt tot de persoonlijke begeleider. In paragraaf 1.3.1 wordt een beschrijving gegeven van de opbouw van een dergelijk woongroepteam.

In deze studie staan woongroepen van residentiële instellingen en de daarbij horende teams van groepsleiders centraal.

\subsubsection{Effectiviteit van woongroepteams}

Residentiële instellingen worden in deze studie opgevat als dienstenorganisaties. Het team van groepsleiders vormt de front-offce: de plaats waar organisatie en cliënt elkaar dagelijks persoonlijk ontmoeten en waar de dienstverlening daadwerkelijk gerealiscerd wordt. De mate waarin deze succesvol en tot tevtedenheid van cliënten verloopt, dragt bij tot het functioneren van mensen met verstandelijke beperkingen en datmee tot hun kwaliteit van bestaan. De mate van tevredenheid van cliënten met de door hen ervaren begeleiding kan beschouwd worden als cen maat voor de kwaliteit van de begeleiding. De mate waarin het woongtoepteam erin slangt bij te dragen tor positieve kwaliteitservaringen van her cliëntsysteem, kan beschouwd worden als een maat voor de effectiviteit van de begeleiding.

Naarmate de emst van beperkingen, de complexiteit van problematiek en dus ook de begeleidingsvragen meeronvattend zijn, groeit de afhankelijkheid van bewoners van hun groepsleiders in het team van hun woongroep. De effectiviteit van de begeleiding door woongtoepteams is daamee een kritische succesfactor voor de organisatie. Deze teameffectiviteit hangt af van vele factoren waaronder: (1) de afstemming tussen de begeleidingsvragen van de cliënten en de feitelijke activiteiten van de reamleden; (2) de competenties, taken, functies, werkverdeling, bevoegdheden, attitudes en werkreacties van teamleden; (3) de onderlinge communicatie, samenwerking en gebruikte technologicën, (4) de relatie tussen het team en de back-offece 
functies van de organisatie (wijze watop de fronfoffoe ondersteund wordt); en (5) de continuiteit van de begeleiding. Op elk van de genoemde terteinen kunnen zich problemen voordoen. In deze studie wordt gekeken naar de factor continuiteit van begeleiding. Deze wordt opgevat als een aspect wan de interne effectiviteit van de organisatie. De door het cliëntsysteem ervaren kwaliteit vormt hiervan als het ware de tegenpool: een aspect van externe effectiviteit (De Jong, 2003).

\subsubsection{Continü̈teit, effectiviteit en kwalliteit}

Gemiddeld vertrekt op jaarbasis ongeveer 32 procent van de vaste groepsleiders uit een woongroepteam. Daamaast kunnen nieuwe groepsleiders in de loop van een jaar instromen en voor kortere of langere tijd deel uitmaken van het woongroepteam. Dit aantal bedraagt gemiddeld rum 100 procent van de omvang van een woongroepteam (Buntinx, 1994, 2001). Bewoners zien in de loop van cen jaar gemiddeld evenveel 'nieuwe gezichten' als er vaste teannleden zijn. Deze uit- en instroom van groepsleiders wordt als "personelswisselfingen" omschreven. Frequente wisselingen worden beschouwd als een belemmerende factor voor onderlinge samenwerking in het team, voor de communicatie met het cliëntsysteen en voor de kwaliteit van begeleiding in het algemeen. Nieuwe groepsleiders hebben tijd nodig om vertrouwd te getaken met elkaar en met de werkwijze van het team (Arrow, McGrath \& Berdhal, 2000), maar uiteraatd ook met de bewoners zelf, hun sociale netwerk, hun individuele ondersteuningsplannen en met specifieke ontwikkelingsof behandelprogramma's (Vlaskamp, 1993; Zijlstra, Vlaskamp \& Buntinx, 2001). Met het vertrek van groepsleiders verdwijnt veel cliëntspecifieke kennis uit het woongroepteam. Daarnaast zijn frequente of omvangrijke wisselingen nadelig voor de cohesie tussen de groepsleden en voor het vermogen om - na vertrek van collega's en binnenkomst van nieuwelingen - de coördinatiestructuren van het team te herstellen (Arrow, McGrath \& Brendhal, 2000). Personeelswisselingen belemmeren daarmee in functionele zin de effectiviteit wan teams.

Professionele begeleiding wan mensen met verstandelije beperkingen komt tot stand binnen een dialoog tussen zorgyrager en zorgverlener. Dezc dialoog is afhankelijke van wederkerige relaties en van wederzijdse responsiviteit tussen groepsleiders en clientsysteem (Bijlsma, 2003; Maes, 2002; Tronto, 1995; Widdershoven, 1997). Vooral bij langdurige en intensieve dienstverlening ann mensen met verstandelijke beperkingen is her cliëntsysteem in hoge mate afhankelijk van de dienstverleners. Responsiviteit, communicatie, persoonlijke betrokkenheid en wederzijds vertrouwen wormen in die situatie essentiele voorwaarden voor het voeren $\mathrm{en}$ in stand houden van deze dialoog (Hasenfeld, 1992; Meininger, 1998; Roovers, 2004; De Ruyter, 1995). Personeelswisselingen belemmeren daarmee ook in relationele zin de effectiviteit van teams. Verstoring van relaties door personcelswisselingen kan leiden tot ernstige nadelige gevolgen voor het functioneren van bewonets (Van Gemert, 1994; Inspectie voor de Gezondheidszorg, 1996; Janssen, Schuengel \& Stolk, 2002; Vlaskamp, 1.993). 
De door het clientsysteem ervaren kwaliteit van de begeleiding is een aspect van het 'consumentenvertrouwen' en vormt daarmee voor de residentiele instelling als organisatie een strategische factor (Hasenfeld, 1992). Zowel clienten van residentiele instellingen zelf, als ouders en familie maar ook professionals en managers van instellingen wijzen met regelmaat op het problematische karakter wan wisselingen van groepsleiders in het team wan een woongroep. In de vakliteratuur - zoals beschreven in hoofdstuk 3 - zijn vele signalen bekend van cliënten en familie van cliërten die zich beklagen over de omvang en de hardnekkigheid van dit probleem. Dit gegreven vormt de beleidsmarige aanleiding voor deze studie.

Ondanks de talrijke kritische uitlatingen over personeelswisselingen in de vakliteratuur en ondanks de beschikbaarheid van wetenschappelijke studies over verloop van groepsleiders - deze worden eveneens behandeld in hoofdstuk 3 - ontbreekt tot op heden een wetenschappelijke benadering van het verschijnsel personeelswisselingen in dienstverlenende teams. De behoefte aan een theoretisch kader voor de studie van personeelswisselingen en een empirische verkenning van de omvang en de impact van personeelswisselingen in dienstenorganisaties, vormen de wetenschappelijke aanleiding voor deze studie.

\subsection{Doel en probleemstelling van de studie}

Het doel van deze studie luidt: "Inzicht verwerven in het verschijnsel personeelswisselingen in woongroepteams van residentiële instellingen voor mensen met verstandelijke beperkingen."

Vanuit het perspectief van organisatic en management kunnen personeelswisselingen worden gezien als een risicofactor voor de effectiviteit van woongroepteams en voor de door het cliëntsysteem ervaren kwaliteit van zorg. Omdat woongroepteams deel uitmaken van een bredere organisatieomgeving, vormen ook de kenmerken van deze omgeving (de woongroepen zelf en hun context) een relevant aspect van het probleem. De samenhang tussen deze factoren vormt het centrale problecm van ons onderzoek.

De genoemde factoren weerspiegelen drie soorten variabelen uit de groepsdynamica van kleine werkteams: de systeemcondities of de context van het team (zoals grootte en ongevingsfactoren), temporele kenmetken van het team (zoals personeclswisselingen), en effectiviteitaspecten van het team (De La Hera \& Rodriguez, 1999; Arrow, McGrath \& Berdahl, 2000). In paragraaf 3.2.1 wordt nader ingegaan op dit specifieke theoretische model. Zoals eerder aangegeven kan onderscheid worden gemaakt tussen de inteme effectiviteit en exteme effectiviteit van het team. Onder interne effectiviteit wordt verstaan: de mate warin het team erin slaagt hat: doelstellingen te realiseten; onder externe effectiviteit wordt in dit onderzoek verstaan: de door het clientsysteem ervaren kwaliteit van de begeleiding. Beide aspecten staan niet los van elkaar; zij vormen als het ware twee kanten van dezelfde medaille. Daarmee heeft de probleemstelling betrekking op vier kernelementen. De
probleemstelling luidt: "Wat is de samenhang tussen personeelswisselingen (PW),
organisatiekenmerken (A), effectiviteit organisatiekenmerken (A), effectiviteit van het teamfunctioneren (B), en de door 
het clentsysteem ervaren linaliteit wan begeleiding $(\mathrm{C})$ ?" Figuru 1.1 roont schemausch de vier kernelementen en de te onderzocken samenhang.

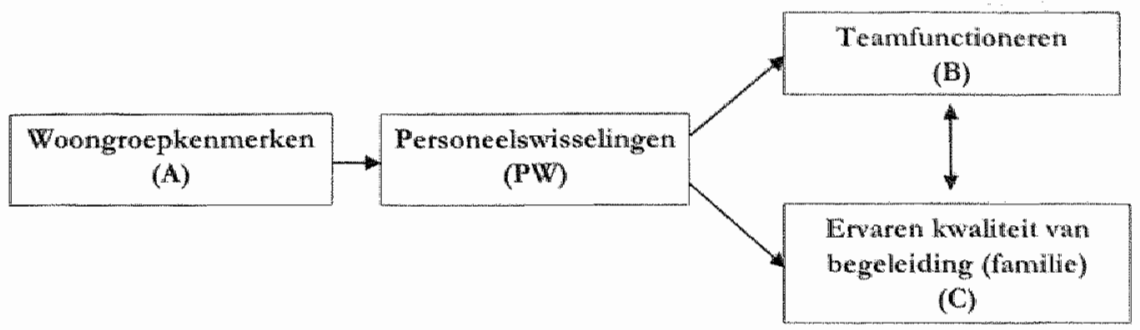

Figuur 1.1 Kernelementen van de probleematelling

De probleemstelling zullen we proberen te beantwoorden in twee stappen. De eerste stap betreft een literatumestudie van de vier kemelementen. Daamee wordt de context van de probleemstelling in kaart gebracht en wordt de literaturur verkend. met het oog op het formuleren van een theoretisch kader en van de onderzoeksvragen voor het empirisch onderzoek naar personcelswisselingen in residentiële instellingen.

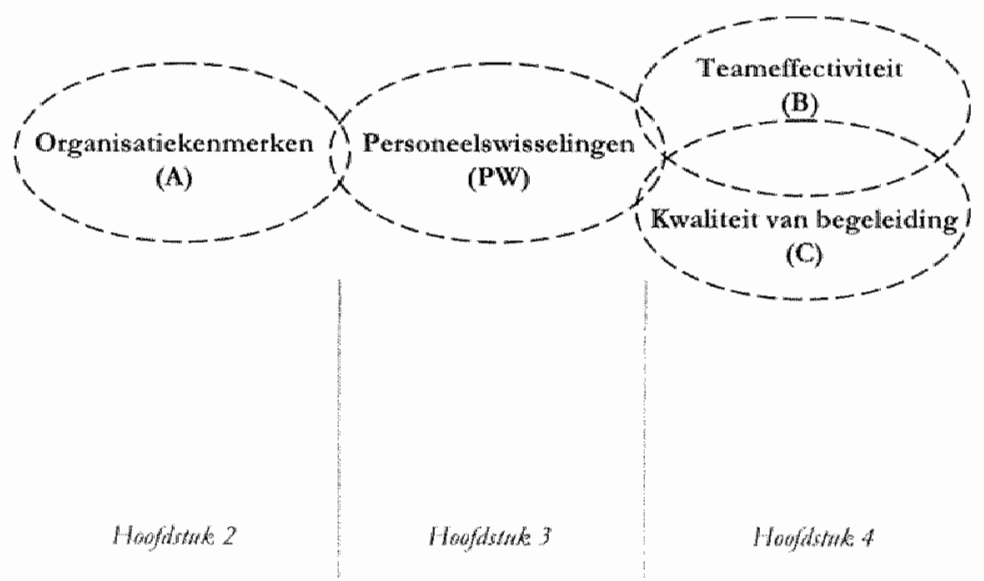

Figuur 1.2 Siructuur stap 1: literatuurstudie (hoofidstukken 2,3 en 4 )

Figmur 1.2 toont de opbouw van deze eerste stap. De eerste stap wordr in hoofdstuk 5 afgesloten met een conclusie en met de fomulering van de vragastelling voor het empirisch onderzoek. De tweede stap betreft cen empirisch onderzoek naar de samenhang tussen de vier kernelementen thoofdstukken $6,7 \mathrm{cn}$ 8. 


\subsection{Begripsomschrijvingen}

Aan het begin van deze studie wordt een omschrijving gegeven van de begrippen die direct verwijzen naar de kernelementen. Het gaat on de centrale begrippen (1) 'woongroepteam', (2) 'personeelswisselingen" als onderscheiden van 'verloop', (3) 'effectiviteit' en 'kwaliteit'. Vervolgens (4) worden omschrijvingen gegeven van de algemene begrippen 'zorg', 'ondersteuning', 'begeleiding' en 'mensen met verstandelijke beperkingen'.

\subsubsection{Kenmerken van het woongroepteam als spil van het primaire proces}

Slechts 1 procent van de cliënten van residentiële instellingen ontvangt een volstrekt individueel zorgarrangement; in 99 procent van de gevallen wonen zij samen met andere cliënten in een woongroep (Vereniging Gehandicaptenzorg Nederland, 2002). Aan een woongroep is in het overgrote deel van de gevallen direct een ream van groepsleiders gekoppeld. Hun begeleidingstaken zijn zeer uiteenlopend en worden bepaald door de aard en de intensiteit van de behoeften en vragen van de bewoners. Zij vatiëren van fysieke hulp bij het wassen, aankleden, eten en mobiliteit, tot het begeleiden van leerprocessen, huiselijke activiteiten, gezondheid, vrije tijd activiteiten, contacten van de bewoner met zijn sociale netwerk en het behartigen wan bewonersbelangen. Gemiddeld driekwart van de dagelijks beschikbare tijd van een team wordt besteed an begeleidingsactiviteiten in aanwezigheid van bewoners. Een kwart van de tijd wordt besteed aan voorwaardenscheppende zaken zoals besprekingen, rapportage, contacten met familie en huishoudelijke zaken zonder participatie van bewoners (Bernard, Buntinx \& Huyer Abu-Saad, 1998). Wanneer de bewoner een school of werkplaats bezoekt is hun directe tijdbesteding bij de domeinen onderwijs en werken uiteraard minder. Dootgaans zijn zij echter wel betrokken bij het traject van toegang tot de dagbesteding. De uitgebreidheid van begeleidingsdomeinen in de woonsituatie brengt met zich mee dat een groepsleider in zijn werk ten overstaan wan de clienten meerdere rollen vervult: van verzorger, tot opvoeder, bemiddelaar, adviseur en belangenbehartiger (Killu, 1994). Vanwege het langdurige, intensieve en wederkerige karakter van de begeleidingstelatie, vervult de groepsleider in de praktijk ook een rol als 'vriend', 'bondgenoot' en 'toeverlaat' van de bewoner (De Groot, 1997; Whiteman \& Jasleulski, 1997; Reinders, 2000; 2002; Roovers, 2004). Uit onderzock naar sociale netwerken van cliënten van residentële instellingen blijken groepsleiders gemiddeld 45 procent uit te maken van het gehele netwerk van hun cliënten (Robertson, Emerson, Gtegoty, Hatton, Kessissoglou, Hallam \& Linehan, 2001).

In de context van een professionele dienstenorganisatie behoren deze uiteenlopende begeleidingsactiviteiten tot de werktaken van groepsleiders. Wetktaken worden gegroepeerd tot functies op basis van complexiteit, vereiste vaardigheden en / of bevoegdheden tot het uitvoeren van bepaalde handelingen. In de sterk geprofessionaliseerde organisatie horen bij bepaalde functies welbepaalde beroepsopleidingen die kwalificeren voor het uitoefenen van de overeenkomstige functie. Globaal betreft het in AIV-voorzieningen (nog steeds) drie functies: 
groepsleider of zorgmedewerker (opleidingsniveau 3 of 4), (2) medewerker of assistent groepsbegeleider (opleidingsniveau 2), (3) hushoudelike medewerkers of groepsassistent. De bij deze functies horende taken zijn niet strak a fgebakend maar vertonen overlap (figuur 1.3). Verder worden binnen het team van een woongroep stagiaires aangetroffen mit de Beroepsbegeleidende Leerweg (BBL) van de opleidingen Sociaal Pedagogisch werk en Verpleging en Verotging; zij verblijen gemiddeld een periode van 9 manden binnen het team. Ook medewerkers met Instroom-Dootstroom banen (ID banen) kunnen deel uitmaken ran het team, meestal als huishoudelijk medewerker. Hun inzet is in principe additioneel. In sommige organisaties heeft éen van de medewerkers de functie van "gastheer" of 'gastrrouw' die zich nadrukkelijk bezighoudt met de praktisch voonwardenscheppende taken in een woongtoep. De taak wan 'persoonlijk begeleider" hoort bij de 'coördinerende taken'.

\begin{tabular}{|c|c|c|}
\hline \multirow[t]{2}{*}{ Functics } & Taken gropsieders & \\
\hline & Coordineren & $\begin{array}{l}\text { P'alkoisch voomwaterden- } \\
\text { scheppend }\end{array}$ \\
\hline
\end{tabular}

Groepsbegeleider

Medewerker groepsegelcider

Huishordelijk medewerker:

\section{Primaite taken \\ Regelmang uigevoerde taken Incidented ungeroete talken}

Figur 1.3 Relatie tussen functies en taken van groepsleiders

De overtap van functies binnen een team van groepsleidets is een kassick spanningsveld binnen de residentiële begeleiding. Medewerkers van cen team wetken in de praktjk gezamenlijk aan de begeleiding van de bewoners zondet strake opsplitsing van taken. In principe is de coördinatie van de begeleiding en het opstellen en bewaken van de uitwoering van individuele zorgplannen vootbehouden. aan niveau-4 medewerkers. In de prakijk wordt daarvan afgeweken. In de moest recente ontwikkeling wotdt bij het samenstellen van een team meer gelet op het bij elkar brengen van de voor die groep bewoners vereiste competenties dan van functies. De achtergrond hiervan is het verdwijnen van specifieke opleidingen (zoals de Z-opleiding) die de vereiste competenties binnen bepaalde beroepen gestandaardiseerd aanboden. Met deze benadering en de daarbij aansluitende wijziging in opleiden en trainen van medewerkers bestaat nog weinig crvaring (Van Hulst, 2003). 
In deze studie word het begrip 'groepsieider' gebruikt als verzamelbegrip voor de professionele medewerkers van een team dat verbonden is aan een woongroep. Dit is inclusief de aan een team toegewezen medewerkers in ID-banen, teamhoofden en meewerkende afdelingshoofden. Samen vormen zij het 'vaste team' var de woongroep. Leerlingen en stagiaires - die ook binnen een woongroepteam functioneren - worden binnen de context van onze studie niet tot de vaste teamleden gerekend.

Een dergelijk team kent een dynamische structuur van taakuitvoering en interacticpatronen tussen teamleden. Deze staan onder invloed van factoren zoals (veranderende) kenmerken van bewoners, ontwikkelingen in begeleidingswragen van bewoners, kenmerken van de organisaticomgeving, gebruikte technologie (bijwoorbeeld voor onderlinge communicatie en coördinatie), de eigen geschiedenis of ontwikkelingsfase van het team en van wisselingen in de teamsamenstelling. Deze wisselingen hebben effect op de effectiviteit van teams (Arrow, 1997).

\subsection{2 'Verloop' versus 'personeelswisselingen'}

Het begrip 'verloop' verwijst naar de beëindiging van het dienstverband met een medewerker. Het betreft dus het vertrek van medewerkers op het niveau van de organisatie. Verloop wordt uitgedrukt als een percentage ('vertrekkers' / totaal personeelsbestand $\times 100$ ). 'Personeelswisselingen' is een ander begrip. Personeelswisselingen doen zich voor op het niveau van een team en hebben betrekking op vertrek of instroom van medewerkers van het woongroepteam dat de zorg heeft over een bepaalde groep cliënten. Personeelswisselingen kunnen worden uitgedrukt als percentage 'vertrekkers' of 'instromers' in relatie tot het totaal aantal medewerkers in desbetreffende team.

Wanneer een lid van een woongroepteam de arbeidsorganisarie verlaat, is dit een geval wan 'verloop' maar ook van 'personeelswisseling'. In cen zorgorganisatie met meerdete (woon)groepen en meerdere zorgfuncties ligt het echter voor de hand dat ook overplatsingen van de ene naar de andere woongroep of naar een andere begeleidingsfunctic binnen dezelfde organisatie plaatsvinden. Dit betreft dan wel een personeclswisseling, maar geen verloop. Deze overplaatsingen zijn een vorm van interne mobiliteit dic al dan niet beleidsmatig - zoals bij job rotation - of door organisatieveranderingen worden aangestuurd (Allaart \& de Voogd-Hamelink, 2001). Groepsleiders kunnen ook uit her team vertrekken omdat zij tijdelijk toegewezen worden aan een andere woongroep, bijwoorbeeld als tijdelijke versterking van het team, vervanging voor een zieke medewerker of als stagiaire in het kader van een opleiding. In al deze gevallen betekenen personeelswisselingen vanuit het standpunt van de zorginstelling geen verloop. Vanuit het standpunt van de cliènt zijn deze wisselingen voor zijn individuele begeleiding wel degelijk relevant. Personeelswisselingen kunnen daarmee als 'verloop vanuit cliëntenperspectief worden
gekarakretiseerd.

Uit een inventariserende studie bleek dat het jaarlijkse uitstroompercentage van groepsleiders uit de woongroepteams van eenzelfde instelling, gemiddeld vier maal 
groter is dan het verloop op instellingsniveau. Het anntal 'nieuwe gezichten' dat in de loop van een jaar in een woongtoep verschijnt bedragt gemiddeld ruim twalf keer het verlooppercentage van de betreffende instelling (Buntinx, 1994). In een andere studie werd gevonden dat gemiddeld 44 procent wan het aantal wit de woongroepteams vertrekkende groepsleiders was getelateerd an beeindiging van het dienstverband en dat de overige 56 procent door de organtsatie zelf geinduceerde wisselingen betrof (Buntinx, 2002). Het is duidelijk dat de wisselingen zoals die in de praktijk door bewoners worden ervaren hoger liggen dan het verlooppercentage van de instelling. Anders gezegd, het verlooppercentage is geen goede weerspiegeling van de personeelswisselingen respectevelijk van discontinuiteit in begeleidingsprocessen waarmee cliënten van residentiële instellingen in de praktijk worden geconfronteerd. Dit fenomeen rechtvaardigt cen andere benadering van het verschinsel dan de benadering van verloop vanuit het Haman Resomtes Mantgement perspectief dat meer is gericht op problematiek van werving, selectie en behoud van medewetkers (Baumeister \& Zaharia, 1987; Braddock \& Mitchell, 1992; Test, Flowers, Hewitt \& Solow, 2003).

\subsection{3 'Effectiviteit' en 'kwaliteit'}

'Effectiviteit' is een aspect van kwaliteit watmee bedoeld wordt: de mate waarin een gesteld doel wordt bereilst (Harteloh \& Casparie, 1998; Harteloh, 2000). In deze studie wordt dit begrip gebruikt in relatie tot het teamfunctioneren. De mave waarin een team erin slaagt cliënttevredenheid te bereiken behoort tot de 'externe effectiviteit: daarmee wordt een maatschappelijk effect buiten het team - bij het cliëntsysteem - bereikt (outcome). De mate waatin afgesproken of voorgenomen feitelijke begeleidingsactiviteiten plaatsvinden behoort tot de 'interne effectiviteit' van het team (output). De condities waatonder inteme of externe effectiviteit wordt bereikt, worden effectiviteitaspecten of effectiviteitcondities van het teamfunctioneren genoemd. In deze studie wordt niet de feitelijke uitvocring wan begeleidingsactiviteiten binnen het woongroepteam getoetst maat wordt gekeken naar conditics binnen het teamfunctioneren die bevorderlijk zijn voor de externe effectiviteit. De in deze studie gehanteerde begtippen 'teameffectiviteit' en 'effectiviteit van het teamfunctioneren' verwijzen derhalve naar effectiviteitscondities. In de hoofdstukken 3 en 4 zullen deze condities nader onderzocht en geconcretseerd wotden. In hoofdstuk 4 (paragraf 4.2) wordt dieper ingegaan op de aspecten wan kwaliteitszorg die voor deze studie relevant zijn. In het algemeen is de theoretische definitie van Harteloh en Casparie van toepassing: "Er is sprake van kwaliteit, indien er een optimale verhouding bestaat wan erwaringen ten opzichte van verwachtingen met betrekking tot een bepaald aspect van de (gezondheids)zorg' $(1998$, p. 23). Binnen het in deze studie gehanteerde clientperspectief gaat het om ervaringen en verwachtingen wan cliënten en cliëntsysteem ten aanzien van de begeleiding door het woongroepteam. Cliënttevredenheid krijgt daarbij een centrale plaats. Effectiviteit (het teamperspectief) en kwaliteit (het cliëntperspocticf) vormen in deze studie derhalve twee kanten van dezelfde medaille. 


\subsection{4 'Zorg' versus 'ondersteuning' en 'begeleiding' en het begrip 'verstandelijke beperkingen'}

De organisatie van de zorg voor mensen met verstandelijke beperkingen is niet alleen in Nederland maar wereldwijd sterk in beweging en verschuift van een professioneel-bureaucratisch, gesloten systeem naar een cliëntgericht en open systeem. De behoefte om de nieuwe of beoogde situatie te onderscheiden van de bestaande, gaat gepaard met de introductie van nieuwe begrippen en met herdefiniering van bestaande begrippen. Het gebruik van deze begrippen is in een dergelijke overgangsituatie niet eenduidig. Dit kan leiden tot verwarring, tot 'semantische make-up' (Buntinx, 1979), tot 'etikettenzwendel' (Van Gennep, 2000) of het 'Molière-effect' (Harteloh, 2000): begrippen verliezen hun oorspronkelijke betekenis, worden als inwisselbaar beschouwd en worden containerbegrippen. Het gebruik van algemene begrippen of neologismen in de organisatiepraktijk kan daarmee de suggestie van verandering en vernieuwing wekken zonder dat dit samengaat met daadwerkelijke veranderingen in de praktijk van de zorgorganisatie. Begrippen als 'kwaliteit', 'community care', 'cliëntgerichtheid', 'wraaggerichte zorg' zijn de latste decennia hiervoor erg gevoelig. Dit geldt ook voor het begrip 'ondersteuning'. Daarom staan we hierbij wat uitvoeriger stil en differentiëren 'ondersteuning' van 'zorg' en 'begeleiding'. Daarmee wordt beargumenteerd waarom in deze studie wordt afgezien van het nieuwe begrip "ondersteuning'.

De huidige verschuivingen in het denken over 'zorg' aan mensen met verstandelijke beperkingen hangen samen met dric ontwikkelingen.

Ten eerste vindt er een verschuiving plaats in het wetenschappelijke model van 'handicap' waarbij de kemproblematiek niet langer als een defect binnen het individu wordt gedefinieerd maar als een problematische interactie van de persoon met de omgeving. Deze interactie is multidimensioneel en betreft het functioneren van de persoon in cuime zin. Daarom wordt thans ook niet meer gesproken van een 'handicap' maar van 'functioneringsproblemen' (Luckasson et al, 2002; WHOFIC Collaborating Centre, 2002). Contextuele en multiparadigmatische modellen vervangen daarbij de oude medische en medisch-psychologische defectmodellen van 'verstandelijke handicap' (Van Gennep, 1997, 2000, 2002; Greenspan, 1999; Swirzy \& Greenspan, 2003). In het contextuele model krijgt het begtip "ondersteuning' cen centrale plaats. Het verwijst naar het dynamische en beinvloedbare karakter van functionetingsproblemen en vormt daannee de basis voor professionele interventie. Dit wordt in hoofdstuk vier nader toegelicht.

Ten tweede vindt or een maatschappelijke verschuiving plaats warbij mensen met functioneringsproblemen niet langer als een afzonderlijke categorie worden gezien met recht op speciale, categoriale voorzieningen van de 'verzorgingstaat', maar als gelijkwaardige burgers van de "civil society" (Ellemers, 2000). Daarmee komen waarden als emancipatic, zelfbeschikking, individuele diversiteit, keuzemogelijkheden en toegankelijkheid van de samenleving - ook in het Nederlandse overheidsbeleid - nadrukkelijker naar voren (Van Gennep, 2002; Harteloh, 2000; Ministerie 
van Volksgezondheid, Welzijn en Sport, 2002). Gelijk recht op toegang tor algemene sociale, economische, politieke en culturele hulpbronnen stat daarbij centraal (Luckasson et al, 2002).

Ten derde vinden er veranderingen plaats in de inrichting en de organisatie van de hulpverleningspraktijk. De AWBZ uit 1968 vormde de grondslag van de sterk categoriale en geprofessionaliseerde voorzieningen van de verzorgingsstaat. Met het Besluit Zorgaanspraken AWBZ wordt 1 april 2003 de weg naar cen 'gemoderniseerde AWBZ' ingeslagen. Dat betekent dat zorgaanspraken niet meer in temen van voorzieningen en categoriale doelgroepen, maar in termen van functies worden geformuleerd. Zo ontstaat meet zelfbeschikkingsruimte voor het individu en dienstenorganisaties lirijgen een grotere strategische ruimte.

Dit alles heeft gevolgen voor de verhouding tussen hulpverlener en 'cliènt'. Het begrip 'zorg' is geassocieerd met speciale voorzieningen waarin de professional dominant aanwezig is. Op basis van zijn kennis van defecten en remedies bepalt hij 'wat goed is' voor de persoon met functioneringsptoblemen en past deze kennis vervolgens toe door zelf de regie te voeten over behandeling en begeleiding binnen de context van een voorziening. Er is sprake van een 'expert-leek' verhouding. Het begrip 'onderstcuning' is geassocieerd met de autonome positie van de zorgvrager die kiest voor het leiden van zijn eigen leven binnen de lokale samenleving, daarbij beroep doet op hulpbronnen en in dit proces gefaciliteerd dient te worden ondemeer door professionals. In dit geval is er sprake van 'partnerschap' Van Leeuwen, 2004; Maes, Bruyninckx \& Goffart, 2003; Zomerplaag, 2000). Beide begrippen plaatsen de professional dus in een verschillende rol. Figuur 1.4 vat de kenmerken van zorg en ondersteuning samen.

In de omslag van 'zorg' nat 'ondersteuning' zijn instellingen ook organisatorisch aan het veranderen. Dat betekent dat condities voor 'partnerschap' gecteëerd moeten worden met de daarvoor noodzakelijke 'vrijheidsgraden' voor begeleiders in het primaire proces. De weg nar ondersteuning is door residentiele instellingen wel ingeslagen maar nog lang niet afgelegd. In deze overgangssituatie vertonen zij nog veel kenmerken van traditionele zorginstellingen wat cliënten groepsmatig en binnen de professionele condities van de instelling verblijven, terwijl men gelijk. tijdig streeft naar meer individualisering en 'ondersteuning'.

\begin{tabular}{|c|c|c|c|}
\hline \multirow{2}{*}{ Concept } & \multicolumn{3}{|c|}{ Aspeci } \\
\hline & Megie & Reticie porfessicnall-client & Gontext \\
\hline $\begin{array}{l}\text { Zorge } \\
\text { Ondesstcunings }\end{array}$ & $\begin{array}{l}\text { Professional } \\
\text { Personzelf }\end{array}$ & $\begin{array}{l}\text { Expen-leck } \\
\text { patnerschap }\end{array}$ & 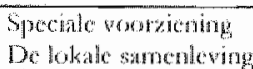 \\
\hline
\end{tabular}

Figuar 1.4 Verhouding tussen de concepten 'zotg' en 'ondersteuning' in rellatie tot drie organdsatieaspecten

De structuur en de cultuur van de traditionele zorgorganisatie beperken echter de individuele keuzemogelijkheden en de ruimte voor individuele zorgatrangementen. Het gebruik van het begrip 'ondersteuning' lost dit spanningsveld niet op en kan zelfs verhullend werken. 
In de context van deze studie wordt het begrip 'zorg' gehanteerd in de hierboven angegeven betekens; het wordt gebruikt waar dit als algemene term is ingeburgerd en ook in andere sectoren van de gezondheidszorg wordt toegepast (bijvoorbeeld in samenstellingen als 'gezondheidszorg', 'maatschappelijke zorg', 'kwaliteitszorg', 'zorgplan', 'zorginstelling', 'zorgstelsel') en als verwijzing naar het total 'product' van de organisatie. Het begrip 'ondersteuning' wordt in deze studie gebruikt in de context van de hierboven besproken verschuivingen en van het nieuwe model van 'verstandelijke beperkingen' dat in hoofdstuk 6 wordt toegelicht. Voor de activiteiten van groepsleiders in hun dagelijkse omgang met de bewoners van residentiele instellingen - het voorwerp van deze studie - wordt het begrip 'begeleiding' gebruikt. Begeleidingsactiviteiten kunnen zowel binnen een context van zorg als van ondersteuning plaatsvinden.

Verder wordt het begrip 'mensen met verstandelijke beperkingen' gehanteerd als meest correcte Nederlandse term (zie paragraaf 6.1). Wanneer het een geijkte term betreft (bijwoorbeeld de AWBZ-term: 'Algemene Instelling voor Verstandelijk gehandicapten') en wanneer dat in de historische context of bij verwijzing naar (oudere) bronnen relevant is wordt het begrip 'zwakzinnig' of 'verstandelijk gehandicapt' gebruikt.

\subsection{Opbouw van de studie en leeswijzer}

De probleemstelling van onze studie luidt: "Wat is de samenhang tussen personeelswisselingen (PW), otganisatickenmetken (A), teameffectiviteit (B) en de doot het cliëntsysteem ervaten kwaliteit van begeleiding (C)?"

Voorlopig kunnen de volgende onderzoeksvragen worden geformuleerd (zie ook figuur 1.1):

1. Is er een verband tussen organisatiekenmerken en personeelswisselingen in residentiële instellingen voor mensen met verstandelijke beperkingen $(A$ PW)?

2. Is et een verband tussen personeelswisselingen en teameffectiviteit ( $P W-B$ )?

3. Is er een verband tussen personeelswisselingen en de door het clientsysteem crvaren kwaliteit van begeleiding (PW-C)?

4. Is er een verband tussen teameffectiviteit en de door het cliëntsysteem crvaren kwaliteit van begeleiding (B-C)?

Figuur 1.5 toont de opbouw van de studie met daatin de plaats van de onderscheiden hoofdstukken.

Het eerste deel van de studie betreft een literatuurverkenning van de viet kernelementen (Organisatickenmerken - A; Personeelswisselingen - PW; Teameffectiviteit - B \& Kwaliteit van begeleiding - C). De literatuurstudie heeft een drievoudig doel. Ten eerste, het beschrijven van de organisatorische context van personeelswisselingen in residentiele instellingen voor mensen met verstandelijke beperkingen in het aigemeen en van de probleemstelling in het bijzonder. Ten tweede, 
het bestuderen van vakliteratuur en van onderzoeksliteratum over de invloed van personeelswisselingen op effectiviteit en kwaliteit van de residenticle dienstverlening. Ten derde, het verkennen van de 'dienstenmarketing' als theoretisch kader en het situeten van cle studie binnen kwaliteitszorg. Aan de hand van de hiemee verkregen informatie zal het empirisch onderzoek worden opgezet.

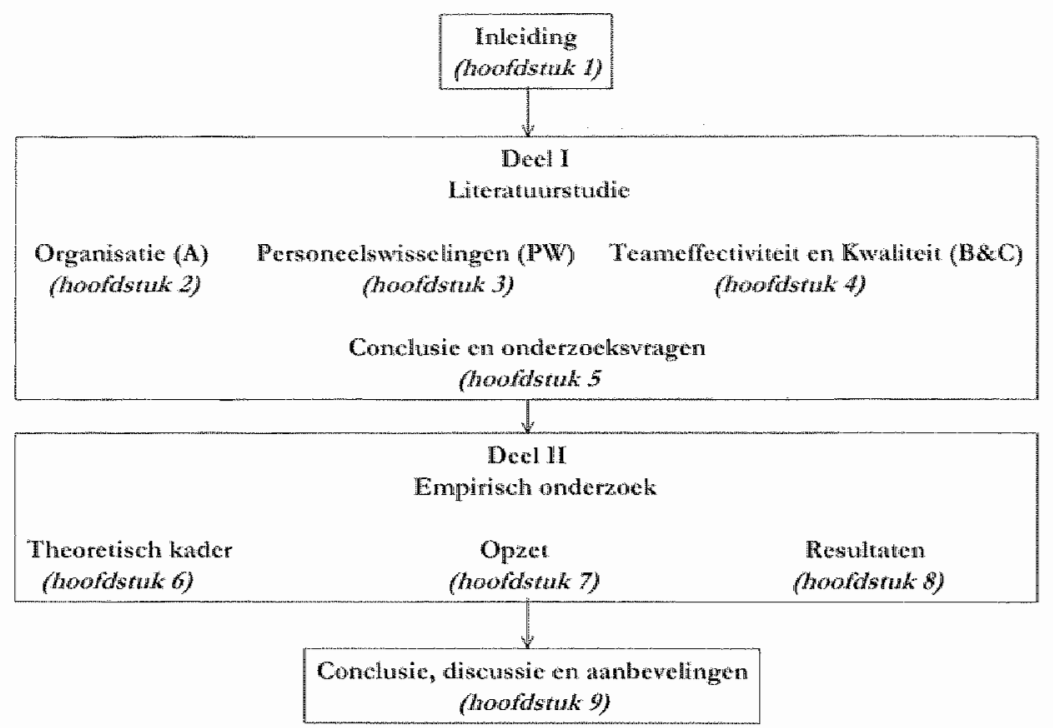

Figuur $\mathbb{1} .5$ Opbouw van de studie

Ondat de organisatie van residentiele instellingen mede getekend is door hun meer dan honderdjarige geschiedenis wordt in boofdstuk 2 een historisch perspectief ingenomen. Na een historisch-sociale schets worden de kenmerken van de huidige Nederlandse residentiële instellingen beschreven.

In boofdstat 3 wordt verslag gedaan van een literatuurstuclie over personeclswisselingen als praktijkprobleem en als wetenschappelijk probleem. In de literatuut over empirisch wetenschappelijk onderzoek wordt specifiek gezocht naar relcvante correlaten voor de studie van personeelswisselingen in het kader van de voorlopige onderzoeksvragen en naar methoden voor het meten van personeelswisselingen.

In boofdstuk 4 wordt de toepassing van het marketingconcept op residentiele instellingen als dienstenorganisaties verkend (4.1). Daarbij staat de effecriviteit van het fromt-office team central en wordt gezocht naar relewante effectiviteitcondities voor dienstenteams. In samenhang hiemee worden vervolgens de kenmerken van kwaliteitszorg en de conceptualisering van kwaliteit vanuit het clièntenperspecticf onderzocht (4.2).

Hoofdstuk 5 sluit het eerste deel af met een conclusie aan de hand warvan de onderzoeksvragen voor het empirische deel nader worden geformulecrd.

Het tweede deel van de studie is her verslag van een empirisch onderzock. 
In boofdstule 6 wordt her algemene theoretische model van 'verstandelijke beperkingen' als uitgangspunt genomen (6.1) en verwolgens wordt langs twee wegen het theotetisch kader van onze empirische studie geformuleerd. De eerste benadering is inhoudelijk en steunt op de sociale ecologie. Personeelswisselingen worden gezien als belemmerende factoren woor de effectieve begeleiding van bewoners binnen residentiele woongroepen (6.2). De tweede benadering is organisatorisch en steunt op een marketingmodel van de relatie tussen 'teamfunctioneren' en de 'door cliënten van dienstenorganisaties ervaren kwaliteit' (6.3). We laten zien dat beide benaderingen - de inhoudelijke en de organisatorische - congruent zijn. Het hoofdstuk eindigt mer de formulering van het theoretisch kader van de empirische studie waarin, mede aan de hand van de in deel I verzamelde relevante factoren, de onderzoeksvragen mer de deelvragen worden geformuleerd (6.4).

Hoofdsizk 7 behandelt de opzet van het empirisch onderzoek. Vertrekkend bij de doelstelling (7.1) volgc een beschrijving van de onderzoeksgroep (7.2), de methode (7.3) en vervolgens de operationalisering van de onderzoeksvragen met de gebruikte meetinstrumenten (7.4). Daarna wordt de procedure van dataverzameling (7.5) en data-analyse (7.6) beschreven. Het hoofdstuk eindigt met de operationele onderzoeksvragen samen met de deelvragen voor het empirisch onderzoek (7.7). Hoofdstuk 8 presenteert de resultaten van het empirisch onderzoek en beantwoordt de onderzoeksvragen met de deelvragen.

In booffltuk 9 volgen de conclusies on beschouwingen naar aanleiding van de resultaten van het onderzoek. Na het overzicht van de conclusies (9.1) volgen een kritische reflectie op en een bespreking van de implicaties van de resultaten (9.2). Tot slot worden aanbevelingen voor praktijk en onderzoek geformuleerd (9.3).

Aanduidingen van tabellen en figuren voorafgegaan door een hoofdletter B, verwijzen naar de bijlagen. Het eerste getal achter de $B$ verwijst naar het hoofdstuk; het getal achter de punt verwijst naar het nummer van de tabel of figur in de bijlage. De titels van overheidsnota's en documenten worden in de tekst schuin gedrukt weergegeven met het jaartal van publicate; deze worden niet in de literatur gerefereerd omdat deze via websites (bijvoorbeeld www.partement.nl cn www.minwws.nl) gemakkelijk toegankelijk zijn. 


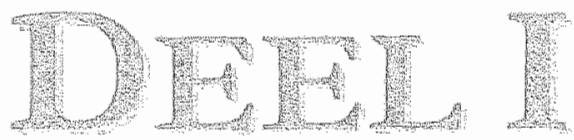





\section{De residentiële instelling} als organisatie: een historisch-sociale schets 

Woongtoepen zijn ingebed in residentiele organisaties die op hun beurt deel uitmaken van een maatschappelijke omgeving. Voor een goed begrip van de organisatorische context van woongroepen volgt een schets - op hoofdlijnen - van de ontwikkeling van Nederlandse residentiele instellingen voor mensen met verstandelijke beperkingen binnen hun historisch-sociale omgering. Met het begrip 'schets' wordt aangegeven dat geen geschiedkundige studie wordt beoogd, maar een globale beschrijving wordt gegeven van de context van residentiele woongroepen in drie periodes.

In paragraf 2.1 wordt de periode vanaf de tweede helft van de negentiende eeuw tot voór de invoering van de AWBZ in 1968 behandeld. Vervolgens, in paragraaf 2.2, de periode van 1968 tot 1990 . Tot slot wordt in paragraaf 2.3 stil gestaan bij de complexe ontwikkelingen in de jaren negentig van de vorige eeuw. In een afzonderlijke paragraaf (2.4) wordt de factor personeelswisselingen vanuit historisch perspectief belicht. Dit hoofdstuk besluit met een overzicht van de actuele situatie (paragraaf 2.5 ).

De historisch-sociale schets is als volgt opgebouwd.

In elke periode wordt een typering gegeven van zowel (1) de externe omgeving (achtergrond) als (2) de interne structuur van residentiële instellingen (organisatic). Dit onderscheid is gebaseerd op de structurele contingentietheorie die stelt dat organisaties zich actief aanpassen aan hun omgeving en dat hun structuur en structuurveranderingen vanuit deze aanpassingsdynamiek moeten worden begrepen (Pennings, 1998; Veen \& Korver, 1998). De organisaticomyeying kan worden beschreven in termen van demografische, regulerende (wet- en regelgeving), economische, technologische (kennis), sociale en competitieve factoren (Ginter, Swayne \& Duncan, 1998, hfst. 8; De Vries \& Goud, 2003). De interne simucturtr van een organisatie - ook wel haar interne architectuur genoemd - wordt bepaald door de configuratie van missie, visie, groepering van diensten en markten, omvang en groepering van de basiseenheden (operating core), structurering van taken en functies, coördinatiesystemen en mate van decentralisatic. De structurele contingentietheorie stelt verder dat de effectiviteit van een organisatie wordt bepaald door de mate van congruentie of goodwess-of fit tussen haar interne architectuur en have omgeving (Miller \& Mintzberg, 1984). Wanneer bijwoorbecld de omgeving een hoge mate van geindividualiseerde begeleiding vraagt en vraggestuurde bekostiging wordt ingevoerd, zal een organisatie die onveranderd sterk groepsgewijze en gestandaardiseerde zorg blijft leveren congruentie met de omgeving verliezen. Daatnaast wordt de effectiviteit ook beinvloed door de consisientie van de interne architectuur. Dit slaat op de onderlinge afstemming en cohesie van de verschillende bouwstenen van de interne architectuur. Wanneer bijvoorbecld onder invloed van nieuw overheidsbeleid wel de visie en de missie van een organisatie worden aangepast, maar taken, functies en opleiding van medewerkers niet worden veranderd, of de ondersteuningstechnologie niet wordt aangepast, dan verminderen daarmee de consistentie en de effectiviteit van de organisatie, ook al past men zich ogenschijnlijk aan de ongevingsveranderingen aan. 


\subsection{Van de $19^{\circ}$ eeun tot de AWBZ}

\subsubsection{Achtergrond van de ontwikkelingen}

De geschiedenis van de huidige Nederlandse residentiele zorg voor mensen met verstandelijke beperkingen gaat terug tot de tweede helft van cle negentiende eeuw. In clie periode vond een sterke stijging plaats wan het aantal mensen dat werd opgenomen in krankzinnigengestichten. Hoewel in deze gestichten ook 'zwakzinnigen' werden opgenomen - hoevecl is onduidelijk - ontstonden parallel aan deze ontwikkeling ook afzonderlijke zwakzinnigenintichtingen. Er kunnen in die vroege periode twee categorieèn zwakzinnigenintichtingen worden onderscheiden. Enerzijds waren er inrichtingen die zich specifiek op zwakzinnigen richtten zoals 's Heeren Loo te Emelo (1891), Assisië te Udenhout (1904) en Boldershof te Druten (1907). Anderzijds waren er inrichtingen zoals Sint Anna (1879) te Heel, Sint Joseph (1910) te Heel, en de Johannes-Stichting te Nieuwveen (1887) die zich op een ruimere groep van hulpbehoevende mensen richtten. Hieronder bevonden zich ook '...ouderen, lichamelijk gehandicapten, epileptici, maar vooral kinderen: verwaarloosde jongens en meisjes, wezen, halfwezen of kinderen met epilepsie die uit andere gestichten wetclen geweerd' (Klijn, 1995, p. 47). In deze tweede categorie inrichtingen maakte de groep zwakzinnigen echter binnen enkele decennia na oprichting meer dan 50 procent van de populatie uit (Jak, 1999).

Verschillende maatschappelijke ontwikkelingen droegen bij tot deze institutionaliseringstendens.

1. Toenemende industrialisatie én de economische crisis aan het eind van de negentiende eeuw gingen gepaard met een groeiende behoefte aan efficiënt werkende arbeidskrachten en met uitstoting van niet-productieve en social afwijkend geachte groepen uit het arbeidsproces. Een belangrijk motief voor de opret van intichtingen was een menswaardig alternatief te bieden voor de ennstige staat van verwaarlozing waarin verstandelijk gehandicapten valk als kind of volwassene terechtkwamen (Jak, 1993; Klijn, 1995).

2. Het in deze periode opkomend kleinere kenngezin bleek kwetsbaarder en minder goed in staat om moeilijke taken zoals de verzorging van een verstandelijk gehandicapt kind te volbrengen (Klijn, 1995, p. 57).

3. Toenemende eisen die gesteld werden aan onderwijs en scholing makiten dat sommige kinderen niet meer konden meekomen. De invoering van de schoolplicht bracht het ptobleem van deze 'achterlijke' kinderen nog pregnanter naat voren (Van Gennep, 1976).

4. Het geloof in de wetenschap. In het midden van de $19^{\circ}$ eeuw hadden artsen als Guggenbühl in Zwitserland en Seguin in Frankrijk en in de Verenigde Staten grote verwachtingen geschapen ten aanzien van de behandeling en opvoeding van zwakzinnige kinderen. Guggenbühl stichtte in 1840 te Interlaken de eerste gespecialiseerde zwakzinnigeninrichting voor behande- 
ling op wetenschappelijke grondstag en inspireerde in Nederland Van Koetsveld tot zijn model voor 'geneeskundige oproeding en christelijke philantropie' en tot de oprichting van de eerste idiotenschool te Den Haag (Kanner, 1976; Van Koetsweld, 1856). Seguin ontwikkelde een theoretische visie met bijbehorende individuele en methodische interventies voor de opvoeding van zwakzinnige kinderen waarbij een vergelijking met het hedendaagse 'methodisch werken' en 'individuele zorgplannen' zich beslist opdringt (Talbot, 1967).

In de visie en de missie van de eerste inrichtingen worden zowel sociale componenten (de beschermende of custodiale funcrie) als opvoedingscomponenten, behandelcomponenten en integratiecomponenten (opvoeden en opleiden tot productieve burgers binnen de samenleving) aangetroffen. In deze periode was de zorg voor mensen met verstandelijke beperkingen een aangelegenheid wan het particulier initiatief; de statsbemoeienis was gering. Caritas en filantropie vormden de ideologische achtergrond (Klinn, 1995; Reinders, 1999).

Een typisch kenmerk van zowel psychiatrische inrichtingen als zwakzinnigeninrichtingen in de negentiende eeuw was de koppeling van interventie (of die nu bedoeld was als beschetming, behandeling, opvoeding of opleiding) met institutionalisering (Van der Poel, Romme, Trimbos \& Van der Wilk, 1985). Deze koppeling ligt aan de basis van de residentiële instelling voor mensen met verstandelijke beperkingen zoals we die anno 2004 nog steeds kennen.

Zowel voor de psychiatrie als voor de vroege zwakzinnigenzorg geldt dat de verwachtingen die waren geschapen ten aanzien van behandeling en opvoeding niet in die mate konden worden waargemaakt dat alle bewoners na verloop van tijd weer een plaats in de samenleving gingen innemen. Guggenbühl's medische behandelingen bleken vooral op wishfull thinking te zijn gebaseerd en niet te leiden tot genezing. Het management van zijn instelling ontspoorde jammerlijk en zijn onderzoeken werden gediskwalificeerd (Kanner, 1976). De pedagogische methoden van Seguin - hoewel succesvol bij mensen met lichte verstandelijke beperkingen waren niet geschikt voor ernstiger verstandelijk gehandicapten ('niet-opvoedbaten') die in toenemende mate naar de zwakzinnigengestichten toestroomden. Overbevolking en snelle uitbreiding van de oorspronkelijk kleinschalige scholen annex inrichtingen, gepaard met een groot gebrek aan pedagogisch geschoolde ktachten, maakten deze voorzieningen weinig effectief. De custodiale functic van de inrichtingen kwam daardoor steeds meer op de voorgrond. De pedagogische functie werd gereserveerd voor de scholen, die na het begin van de twintigste eeuw steeds meer bestuurlijk werden losgekoppeld van de inrichtingen.

In de jaren twintig en dertig van de vorige eeuw stelde de beweging voor 'psychische hygiene" in Nederland het 'zwakzinnigenvraagstuk' als een maatschappelijk probleem aan de orde. Zwakzinnigheid werd in relatic gebracht met allerlei sociale problemen zoals armoede en misdaad. Dit had deze beweging 
gemeen met de eugenetische beweging die vooral in de Angelsaksische landen tussen 1875 en 1930 invloed kreeg op de zorg voor zwakzinnigen (Kanner, 1976). Hoewel de eugenetische beweging in die periode in Nederland niet de dramatische impact heeft gehad die zij in de Angelsaksische landen en in Duitsland heeft gekregen, heeft zij wel het denken in Nederland mede gelleurd. Hier heerste echter niet zozeer de opvatting dat zwakzinnigheid de oorzaak van deze maatschappelijke problemen zou zijn, maar dat zwakzinnigen hiervan juist zelf te lijden hadden. Wellicht paradoxaal - zegt Klijn (1995) - leidde het eugenetische gedachtegoed door de reactie van de beweging voot geestelijke hygiëne juist tot het benadrukken van de noodzaak tot individuele ontplooiing van zwakzinnigen en de wenselijkheid van een professionele aanpak.

De missie van de residentiële instellingen was in deze periode hoofdzakelijk gericht op scholing, opvoeding en onderwijs van kinderen in een aan de instelling gelieerde maar bestuurlijk zelfstandige school. Wanneer reintegratie niet lukte volgde voor volwassenen tewerkstelling in eigen werkplaatsen die nauw verbonden waren met de bedrijfsvoering van de instelling (bijwoorbeeld: timmerwerkplaats, boerderij, keuken, wasserij, huishoudelijk werk op een afdeling). Wanneer ook dit niet lukte, kwam de nadruk te liggen op verzorging.

Hoewel zotg voor krankzinnigen en zorg voor zwakzinnigen afzonderlijk tot stand kwamen, waren er ook dwarsverbindingen. Al in 1875 was de inspectie van het krankzinnigenwezen ervan overtuigd dat de zorg voor zwakzinnigen als een zelfstandig terrein gezien moest worden. Later vond men dat - met behoud van de eigenheid van deze zorg - zij toch behoorde tot het domein van de psychiatrie. Zwakzinnigenintichtingen werden, op grond van een in 1904 aangebrachte aanvulling in de Krankzinnigenwet, vaak als 'aangewezen inrichting' erkend. Deze kwalificatie wees niet op een inhotidelijke relatie tussen beide systemen maar was primair gemotiveerd om wachtijisten te ontlasten en overbevolking in de krankzinnigengestichten tegen lage kosten te reduceren (Klijn, 1995). Wel kwamen zwakzinnigeninrichtingen daarmee onder het Staatstoezicht op krankzimnigengestichten en daarmee binnen de invloedsfeer van het medisch denken.

Om professionalisering van de zorg te bevorderen stimuleerde de Inspectie van het Statstoezicht op het krankzinnigenwezen de organisatie van cursussen over verpleging en verzorging van 'zielszieken'. Professionalisering lukte echter maar langzaam. Redenen waren: (1) een pessimistische visie op de ontwikkelingsmogelijkheden van (ernstig) zwakzinnigen; (2) de reputatie van de zwakzinnigenzorg als 'ondankbaar' arbeidsterrein; (3) het isolement van het inrichtingsleven; (4) het ontbreken van samenwerking tussen zwakzinnigeninrichtingen onderling en met de krankzinnigeninrichtingen; en (5) de asymmetrie tussen de mondigheid van 'patiènten' en hun verzorgers en de afhankelijke positie van de familie die lange tijd aan de zijlijn van de zorg heeft gestaan (Klijn, 1995). 


\subsubsection{Organisatie}

's Heeren Loo startte in 1891 met 2 paviljoenen voor respectievelijk 16 en 36 personen, gevolgd door de bouw van paviljoenen voor elk 50 personen (figuur 2.1). Dit paviljoenstelsel was geinspireerd op de Duitse Alsterdorfer Anstalten die in 1863 door Heinrich Sengelmann bij Hamburg waren opgericht (Vette, 1993). Een paviljoen was onderverdeeld in een drietal woongroepen ('afdelingen') warbij de groepssamenstelling was gebaseerd op geslacht, leeftijd, epilepsic, onzindelijkheid en later ook op 'graad van achterlijkheid' (Jak, 1993; Vette, 1993).

In instellingen als Sint Anna en Sint Joseph te Heel was geen paviljoensysteem in gebruik maar waren 'zalen' of 'afdelingen' binnen grote kloosterachtige gebouwen de thuisbasis van de bewoners (figuur 2.2). Bewoners in de eerste en tweede klasse hadden hun eigen kamer of deelden die met een medebewoner. In de derde klasse maakten bewoners gebruik van slaapzalen. De grootte van afdelingen liep sterk uiteen, van vijftien ('idiote bedlegerige kinderen') tot overwegend vijfentwintig en maximaal vijfig. De groepssamenstelling was gebaseerd op combinaties van verschillende criteria waarvan de belangrijkste waren: geslacht, leeftijd, niveau van functioneren, epilepsie en 'moeilijke gevallen' (Klijn, 1995).

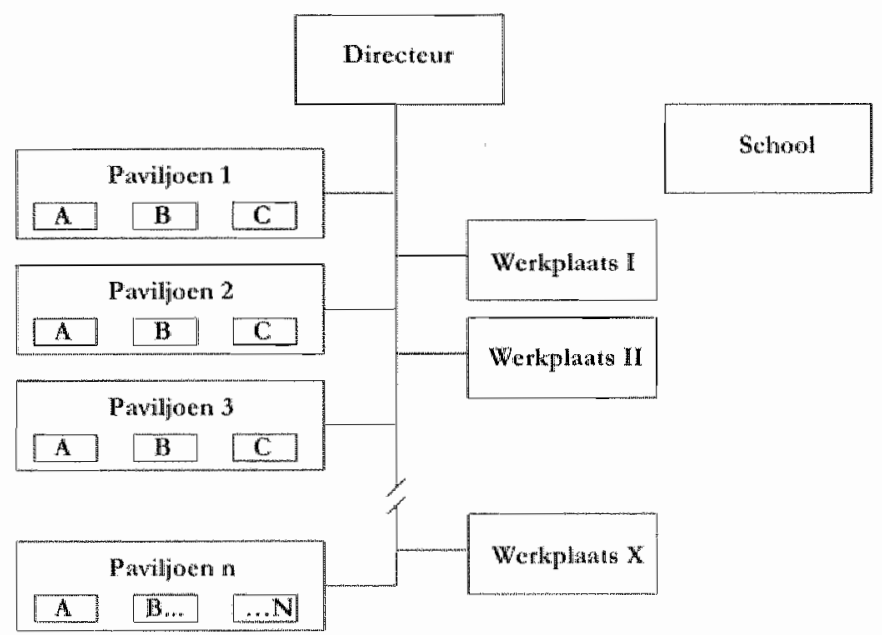

Figuur 2.1 Prototypisch organisatiemodel residentielle instelling voor mensen met verstandelipke beperkingen: paviljoensysteem met woongroepen $(A, B, \ldots N)$ bii s Heeren Loo $(1891-1950)$

De organisatiestructuur van Sint Anna en Sint Joseph was uitgesproken 'plat'. Tussen de afdeling en de overste van het klooster was geen hierarchische laag. De afdelingszusters en broeders bezaten een grote mate van autonomie in het begeleiden wan hun woongroep. Ook 's Heeren Loo kende een uitgesproken 'platte' organisatiestructuur. In beide gevallen was het afdelingshoofd, respectievelijk paviljoenshoofd direct verantwoording verschuldigd aan de overste van het klooster respectievelijk aan de directeur van de inrichting (figuren 2.1 en 2.2). $\mathrm{Als}$ gevolg van deze autonomie kende elke woongroep een eigen karakter. 


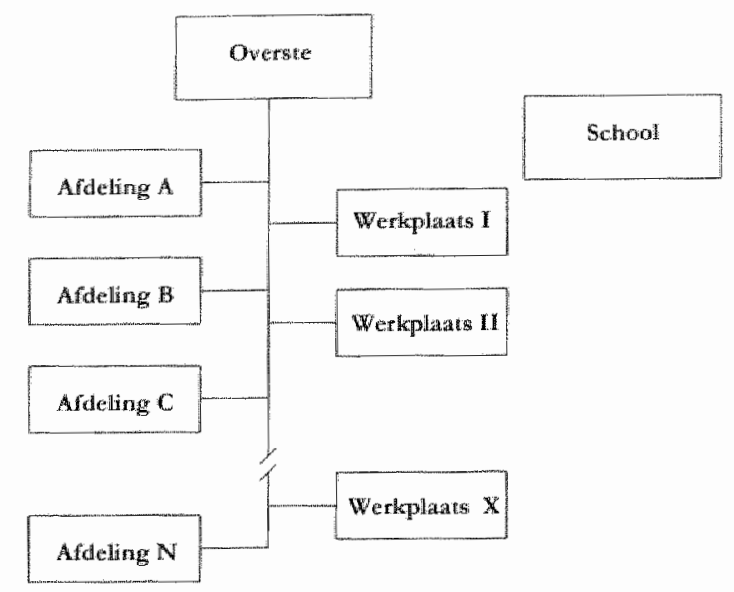

Piguur 2.2 Prototypisch organisatiemodel residentiate instelling woor mernsen met verstandelijke beperkingen: afdelingsysteem $\left(A_{i} B_{k} \ldots N\right)$ bij Sint Anna $(1879-1950)$

Bij problemen of meningsverschillen konden bewoners terecht bij de overste of de directeur, bij de arts of bij de consulentupsychiater (Klijn, 1995). Gezien de lage bezoekfrequentie van de psychiater en dc grote populatie van de instellingen was zijn invloed relatief klein. Hoewel de arts wel invloed had op opname en ontslag, had hij maar weinig invloed op de organisatorische gang van zaken en het regime ( $\mid \mathrm{ak}, 1993$; Klijn 1993; 1995). Het zou onjuist zijn de volledige periode van eind negentiende eeuw tot an de AWBZ globaal als zorg volgens het "medisch model" te bestempelen. Ook het beeld van 'opberginstituten' klopt niet met het feit dat vóór 1940 sprake was van meer doorstroming en een kortere verblijfsduur dan de periode daarna. Vanaf 1945 verandert de samenstelling van de populatie sterk en blijwen alleen de zwakzinnigen over (Klijn, 1995). In deze beginfase ging her - in Mintzberg's typologie (1983) - om 'eenvoudige organisaties' met een sterk gecentraliseerd gezag dat valk uir niet meer dan één persoon bestond. De directeur respectievelijk de overste hadden zeggenschap over de woon-en werkfuncties. Op de scholen was afzonderlijke wetgeving van toepassing hoewel er wel bestuurlijke relaties (bijvoorbeeld door personele unies) bestonden met het instituut.

$\mathrm{Na}$ de tweede wereldoorlog zette de tendens tot professionalisering door. Mecici beschouwden de zwakzinnigenzorg niet als hun exclusief domein maar als een multidisciplinaire aangelegenheid waarin ook psychologen, pedagogen en maatschappelijk werkers hun taken hadden. Tot in de jaren zeventig hieiden zij zich wel. bezig met het management en de sturing van de zorg binnen de inrichting.

De professionalisering van de medewerkers kreeg in 1957 een impuls door het initiatief tot een specifieke opleiding in de Z-verpleging (Hoejenbos, Van der Most, Schoonhoven, Smulders \& Veerman, 1958) die pas veel later, in 1978, wettelijk erkend zou worden. Een ander teken van toenemende professionalisering is het tot stand komen van het "Tijdschrift voor zwakzinnigheid en zwakzinnigenzorg' in 1963. 
Samenvattend kan deze periode als volgt worden gekarakterisectd:

1. Residentiële instellingen woor mensen met verstandelijke beperkingen ontstaan in een demografisch, sociaal en economisch bewogen periode (industrialisatie, verstedelijking, kleinere gezinnen, economische crisis) en proberen een antwoord te geven op situaties van emstige verwarlozing en verkommering. Meerdere visies op zwakzinnigheid staan naast elkaar en treden wisselend op de voorgtond. Naast de medische visie (defect - behandeling) bestaan nadrukkelik ook pedagogische en matschappelijke visies op het ptobleem van mensen met verstandelijke beperkingen en de voor hen gewenste zorg. Kennis is beperkt en wordt gezocht bij de psychiatric, de pedagogiek (voor mensen met lichte verstandelijke beperkingen) en verpleegkunde (voor mensen met ernstige verstandelijke beperkingen). Behandeling, opvoeding en opleiding, bescherming (tegen de eisen of omstandigheden in de samenleving) vormen de doelen van de zorg. Artsen waren weliswaar de dominante discipline maar waren zelf grote pleitbezorgers van pedagogische en multidisciplinaire benaderingen. De doelgroep van de eerste instellingen is zeer heterogeen en blift dat tot na de tweede wereldoorlog. Het private initiatief domineert en overheidsinvloed is beperkt, zij het dat de rol van de inspectie voor de volksgezondheid op de kwaliteit en ontwikkeling van de inrichtingen niet mag worden onderschat. Er zijin zeer beperkte financiële middelen.

2. Organisaties zijn eenvoudig en 'plat' en worden hoofdzakelijk door interne regels gestuurd. De woongroepen vormen de basiseenheden met een omvang van vijftien tot vijfentwintig bewoners met uitschicters tot vijftig. Coördinatie gebeurt door leidinggevenden op paviljoens- of afdelingsniveau en verder door de directie. In algemene en in protestants-christelijke instellingen was sprake van betaalde medewerkers in de afdelingsteams; ook werd aandacht besteed aan (verpleegkundige) scholing. In de katholieke instellingen bestonden de afdelingsteams tor aan het eind van de jaren vijftig van de twintigste eeuw nagenoeg uitsluitend uit religieuzen zonder specificke scholing. Binnen de teams was weinig functiespecialisatie; bewoners wetkten mee hetzij in hun eigen, hetzij in een andere woongroep. De groep bewoners is zeer heterogeen (naat problematiek, sociale situatie en lecftijd). Pedngogische, medische en sociale technologieèn blijken vaak ontoercikend om de ambities van de instellingen te realiseren. Zorgorganisaties zijn wisselend op de buitenwereld georienteerd: doel wan de zorg is in principe reintegratie, maar dit lukt lang niet altijd. Err is constant capaciteitsgebrek (wachtlijsten en overbevolking). 


\subsection{Van 1968 tot 1990}

\subsubsection{Achtergrond van de ontwikkelingen}

In 1968 werden de door de overheid erkende zwakzinnigeninrichtingen binnen het financieringskader van de AWBZ opgenomen. Dit leidde tot drie effecten. Ten cerste vonden er grote bouwactiviteiten en capaciteitsuitbreidingen plaats. Deze hingen samen met zowel het stichten van nieuwe voorzieningen als het uitbreiden van bestaande vootzieningen. 'Zwakzinnigen' uit de psychiatrische instellingen (op dat moment ongeveer 30 procent van de populatie) werden overgebracht naar de nieuwe 'zwakzinnigeninstellingen'. De uitbreidingen van bestaande instellingen waren bedoeld voor het opvangen van de overbezetting die hierin tijdens de afgelopen vijfrig jaren was ontstaan - gemiddeld 25 procent in katholieke zwakzinnigeninrichtingen - en het reduceren van de grote wachtlijsten (Klijn, 1995). Ten tweede zorgde de $A W B Z$ voor een doorbraak in de professionalisering van de zorg voor mensen met verstandelijke beperkingen. Naast de medische en de verpleegkundige discipline deden nu disciplines als psychologie, (ortho)pedagogiek, maatschappelijk werk en de paramedische disciplines fysiotherapie en logopedie definitief hun intrede. Ten derde consolideerden de AWBZ en de Wet Ziekenhuisvoorzieningen $(W Z v)$ de bestaande koppeling tussen 'zorg, bed en bouw'. Dit had grote gevolgen voor de zorgcultuur van de residentiële instellingen. De gedachte van de verzorgingsstaat creëerde maatschappelijk aparte categorieën waaronder "verstandelijk gehandicapten', waarvoor zoveel mogelijk bijzondere voorzieningen in het leven werden geroepen (Ellemers, 2000). De AWBZ was daarbij een succesvol instrument.

Voor een goed begrip van de Nederlandse zorg voor mensen met verstandelijke beperkingen dient men zich te realiseren dat de AWBZ hoort tot het domein van de gezondheidszorg en steunt op een medisch zorgmodel. Opvoedings- en resocialisatiefuncties die voorheen in de praktijk nadrukkelijk ook aanwezig waten, waren minder verankerd in de AWBZ. Hierdoor werden de custodiale en verzorgende aspecten in de residentiële zorg geaccentueerd.

Inmiddels was in het buitenland - vooral in Scandinavië, Engeland en de Verenigde Staten - vanaf de jaren vijftig een volstrekt andere zorgvisie tot ontwikkeling gekomen: Normalisatie (Buntinx, 1997a; Van Gennep, 2000). Deze visie ging uit van het bevorderen wan gewone lefpatronen voor mensen met verstandelijke beperkingen binnen normale maatschappelijke settingen van wonen, werken, onderwijs en vrije tijd. De nieuwe technologie van de gedragsmodificatie - als spin off van de empirische leerpsychologie en de gedragstherapie vanaf begin jaren zeventig beschikbaar gekomen - vormde een bruibaar instrument on de aanpassing van mensen met verstandelijke beperkingen aan genormaliseerde situaties te bevorderen. Als beleidsuitgangspunt stond Normalisatie in beginsel afwijzend tegenover inrichtingen die een besloten instituutscultuur met zich brachten en ver afstonden van het leven in de gewone samenleving. In Nederiand kwam de kennismaking met deze nieuwe visie pas goed op gang met de landelijke NGBZ 
studiedag in 1973, dus num nadat de AWBZ in werking was getreden, het 'medische model' was geconsolideerd, en de grote renovatie en expansie van intichtingsplaatsen volop op gang was gel:omen.

Het is typisch dat in Nederland aan de component 'integratie' van de Normalisatievisie een eigen gewicht werd toegekend. Vanat de jaren vijtrig waren onder regie van een ander departement - het ministerie van Cultuur Recrearic en Maatschappelijk werk - naast residentiële instellingen en speciale scholen ook gezinsvervangende tehuizen en dagverblijven voor verstandelijk gehandicapten ontstaan. Dit ministerie ging speciaal over 'integratie' van tandgroepen en gehandicapten. De residentielle instellingen bleven onder de regie van het ministerie van Volksgezondheid.

Vanaf het midden van de jaren zeventig ontstaat een ambivalente situatie in de Nederlandse residentiële instellingen die enerzijds voor hun financiering en bouwkundige inrichting gestuurd worden door regels die gebaseerd zijn op een medisch zorgmodel, en die anderzijds op grond van de nieuwe zorgvisie proberen zich te ontwikkelen in de richting van Notmalisatie. Zo werden onder invloed van de Normalisatievisie vanaf de tweede helft van de jaren zeventig kleine genormaliseerde woningen gebouwd. Eerst op het terrein van de instelling als "leerschool" voor een overgang naar de samenleving (de 'fasehuizen'), later daarbuiten (de 'buitenpaviljoens') als voorlopers van de 'sociowoningen'. De eerste Nederlandse publicatie over de overgang van bewoners van een grootschalige residentiële instelling naar een kleinschalige woonvorm in de samenleving betreft een group home van acht bewoners van de instelling Vijwervreugd te Middelburg (Bleekrode, Beckers \& Strum, 1974). Onder invloed van Normalisatie werd gestreefd naar kleinere woongroepen. Van gemiddeld ruim 18 aan het begin van deze periode daalde de gemiddelde groepsgrootte tot ongeveer 12 à 10 aan het eind van de jaren tachtig. Binnen eenzelfde instelling bleven grote verschillen in groepsgrootte bestaan; vaak waren woongroepen wan zeer ernstig en meervoudig verstandelijk gehandicapten groter (tot 15).

Het regionalisatieprincipe uit de Structuurnota (1974) wan staatssectetaris Hendriks leidde ertoe dat naast een beleid van kleinschaligheid en Normalisatie ook een beleid van (her) spreiding van capaciteit van residentiejle instellingen werd ingeluid. Spreiding bij de stichting van nieuwe voorzieningen en herspreiding bij de renovatie van bestaande voorzieningen waren mede bedoeld om de zorg kleinschaliger te maken en meer naar de gebruikers toe te brengen (Heiligers, 1974). Daarbij werd het Normalisatieprincipe ook bij de bouw van nieuwe instellingen toegepast wat leidde tot het uitsluitend voor Nedetland typisch 'genormaliseerde instituut' waatvan de instellingen Sintmaheett te Tolbert (1983) en Masveld te Maastricht (1984) de exponenten zijn. Daarnaast werd in bestaande instellingen de 'verdunningsgedachre" geformuleerd (later omgedoopt tot "omgekeerde integratie") waarbij naast huisvesting van mensen met verstandelijke beperkingen ook woningbouw voor 'gewone huishoudens' of gewone maatschappelijke functies (kantoren, 
werkplatsen) 'op het terrein' wordt gerealiseerd. De Hafakker bracht dit idee in 1986 als eerste in de praktijk (Bergets, 2000) pas veel later gevolgd door andere instellingen die ook kantoren en particulieren op het instellingsterrein ontvingen en daarmee het besloten karakter langzamerhand openbraken (Van der Velde, 1997). Buiten Nederland werd normalisatie van inrichuingen gezien als een oxymoron. Daar werden alternatieve kleinschalige voorzieningen door nieuwe organisaties dus buiten de bestaande instellingsorganisarie - opgezet; bestaande instellingen werden afgebouwd en opgeheven (deinstitutionaliseting). Dat dit niet op dezelfde wijze in Nederland gebeurde hangt samen met het bestaan van een afzonderlijk circuit van semimurale woonvormen - de gezinswervangende tehuizen - waardoor men al een kJeinschalig, genormaliseerd en geintegreerd woonalternatief aanwezig achtre. Daarenboven was de kwaliteit van de Nederlandse residentiële instellingen vergeleken met die in het buitenland (wooral de Verenigde Staten en Engeland) relarief goed (Van Gennep, 1989; 1997). Fir ontbrak daardoor een sense of urgence voor verandering.

De stevig op elkaar afgestemde regelgeving van de AWBZ, de WZv en de Wet Tarieven Gezondheidszorg (1980) zorgde vanuit het perspectief van financiering en planning voor een goed beheersbaar aanbod van voorzieningen (Spanjer, 1997). Binnen cen dergelijk regime is beleidsmatige en organisatorische omschakeling op geleide van een nieuwe zorgvisie financieel en regeltechnisch uiterst lastig. Waat men toch naar fundamentele verandering en vernieuwing streefde, leidde clit tot conflicten zoals ondermeer in Dennendal (Tonkens, 1999). Waar de weg van geleidelijke verandering naar kleinschaligheid en integratie werd ingeslagen, schoot men door de binnen het beleid ingebouwde ambivalenties maar weinig op (Bij de Vaate, 1991).

Hoewel kleinere regionale residentiële instellingen goede vootwaarclen in zich droegen om de beieidsdoelstellingen van de Structuumota en later van de beleidsnota Geestelijk Gehandicapten (1983) te realiseten (tot regionale afstemming to komen met de Gezinsvervangende Tehuizen, dagverblijven voor kinderen en ouderen, Sociale Werkwoomiening, en de ambulante zorg), werden deze in de praktijk nauwelijks gerealiseerd. Redenen daarvoor waren:

1. De versnippering van beleidsverantwoordelijkheden over verschillende departementen (Volksgezondheid en CRM tot 1984) en het tot in 1989 in stand blijven van twee afzonderlijke directoraten binnen VWS (voor intrarespectievelijk voor semi- en extra-murale zorg);

2. Her naast elkaar bestaan van de verschillende wettelijke kaders van de WZv en de Tijclelijke Verstrekkingenwet Wet Maatschappelijke Dienstverlening (Bij de Vaate, 1991);

3. Het naast elkaar bestaan van stichtingen voor intranurale zotg en stichtingen voor semimurale en ambulante zorg. 4. Cultuurverschillen tussen de 'grootschalige' intramurale en de 'kleinschalige'
semimutale sector; 
5. De saneringen van de openbare financien in de jaren tachtig die een zekere terughoudendheid en ongeloof in nieuw (wellicht duurder) beleid met zich meebrachten (Bij de Vaate, 1991).

Hierdoor bleven de residentiele instellingen opgesloten binnen hun eigen cultuut. Door de grote verscheidenheid aan activiteiten en geprofessionaliseerde diensten konden inrichtingen voor zwakzinnigen ontwikkelen tot een soort 'oligodimensionele maatschappij' of 'samenlevingsvorm op maat' (Van den Brink, 1979). Zij boden een alternatief voor leven binnen cle samenleving.

Onder druk van de lange wachtlijsten en de vergrijzing van de aanwezige populaties, ging intussen de uitbreiding van de capaciteit van residentiële instellingen in snel tempo door (tabel B2.1). Dit droeg bij tot het beeld dat Nederland, in tegenstelling tot vooral de Scandinavische en Angelsaksische landen, achterbleef bij de ontwikkeling naar Normalisatie en deïnstirutionalisatie (Hatton, Emetson \& Kieman, 1995; Mansell \& Ericsson, 1996; Buntinx, 1997b).

Onderzoek toonde aan dat de levensverwachting van mensen met verstandelijke beperkingen in deze periode sterk toenam en een belangrijke planningsfactor diende te worden: zelfs bij halvering van de opnamecijfers uit de jaren 1979- 1983 zou tot 2000 nog een autonome groei van 3 procent van de instellingspopulatie plaatsvinden (Maaskant \& Haveman, 1988). Niet alleen door vergrijzing nam de zorgzwaarte toe, maat ook door het feit dat nieuw opgenomen bewoners een grotere zorgafhankelijkheid hadden dan de aanwezige bewoners. Deze trend zette trouwens ook in de volgende periode door (Maaskant, 1993; Bernard, Maaskant, Gevers \& Wierda, 2001).

\subsubsection{Organisatie}

$\mathrm{Na}$ de invoering van de $A \mathrm{WBZ}$ ontwikkelden de residentiële instellingen zich snel tot professionele functiegerichte organisaties of - in Mintzberg's typologie (1983) - 'professionele bureaucratieën'. De door de uitvoeringsregelingen van de $A W B Z$ vrij precies genormeerde functies en disciplines werden in de organisatie van instellingen weerspiegeld in de diensten op het terrein van wonen (verplegingsdienst of woondienst), activiteiten (activiteitendienst: arbeidsactivering, bewegingsagogie, ontspanningsdienst, activiteitenboerderij), behandeling en begeleiding (behandeling en begeleidingsdienst: medische, paramedische, psychopedagogische, maatschappelijke dienst), en de voorwaardenscheppende huishoudelijke, technische, administratieve diensten en personele zaken (figuur 2.3). De opleidingsfunctie van groepsleiders was bij de grotere instellingen in eigen hand (in-service opleiding $Z$-verpleegkundigen). De regie lag meestal bij een driehoofdige directie: een algemeen directeur (A), een zorgdirecteur (B) en een directeur met financiële en facilitaire diensten in de portefeuille (C).

Arbeidswoorwaarden ontwikkelden zich in vergelijking tot de periode vór de AWBZ gunstig. Collectieve Arbeidsovereenkomsten deden hun intrede, ondernemingstaden werden ingesteld en ook de ouderparticipatie kreeg vanaf de jaren zeventig geleidelijk an vorm binnen de instellingen waarbij overleg met ouder- 
organisaties op instellingsniveau werd afgesptoken. Het verloop van medewerkers was laag en de werving van nieuwe medewerkers stelde tot ongeveer het eind van de tachtiger jaren niet al te veel problemen.

Herspreiding van instellingscapaciteit komt langzaam op gang. Sociowoningen ontstaan, eerst als satellieten van afdelingen of paviljoens, later als afzonderlijke clusters. Zij maken integraal deel uit van de instellingsorganisatie en kennen maat beperkt zelfstandigheid.

Zoals ook in de periode vóór 1968 , bleef de 'afdeling' of het paviljoen de basiseenheid voor de organisatie van de woonfunctie. Waar een paviljoensysteem bestond, bevatten deze twee tot acht onderscheiden woongroepen. Verschillende afdelingen of paviljoenen werden soms gegtoepeerd tot clusters (divisie formule). Ondanks deze groepering bleef de koppeling tussen woongroep en bijhorend team van groepsleiders bestaan.

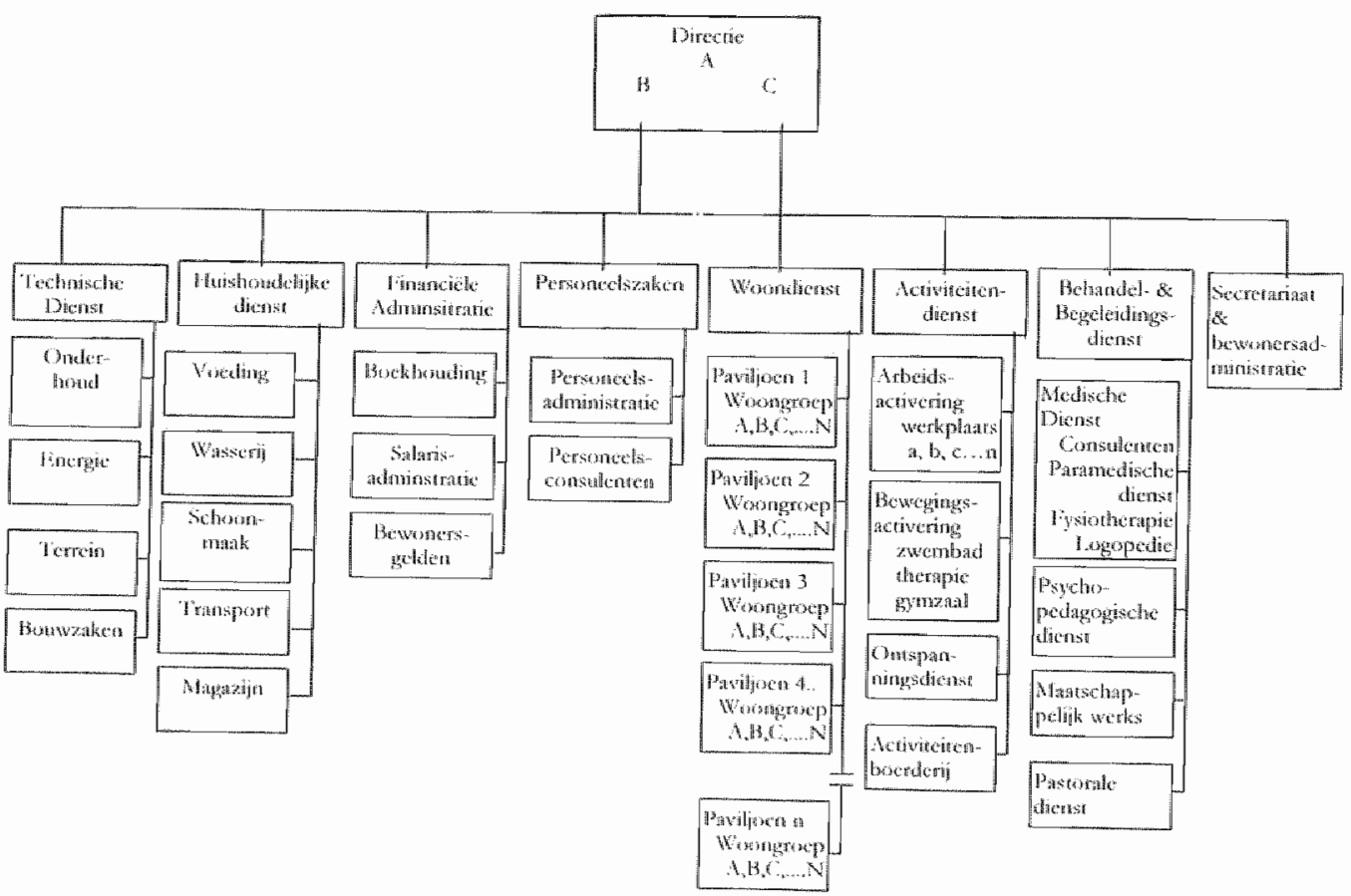

Figunur 2.3 Prototypisch organisatiemodel residentiële instelling voor mensen mer verstandelijke beper-
kingen: de professionele bureaucratic

Samenvattend kan deze periode als volgt worden gekarakteriseerd:

1. De bevolkingsgroei neemt tussen 1965 en 1990 met 22 procent toe, maat de stijging van bewoners wan AIV is in die periode vele keren groter (tabel B2.1). De belangrijkste demografische ontwikkeling doet zich binnen de populatie van mensen met verstandelijke beperkingen voor: vergrijzing. Dankzij de AWBZ komen financiële middelen veel ruimer dan voorheen beschikbaar en dit leidt tot een kwantitatieve en kwalitatieve expansie van de 
zorg. Door wet- en regelgeving ( $A W B Z$, WTG \& WZN), en via de collectieve arbeidsvoorwaarden neemt de overheidsbemoeienis met de zorg sterk toe. In de sector ontstaat een strakke koppeling tussen 'zorg, bed, bouw'. Aan het begin van de AWBZ-periode overheerst nog een defectvisie maar onder invloed van Normalisatie krijgt het ontwikkelingsmodel in de praktijk van de zorg steeds meer de bovenhand. Professionalisering kent een doorbraak: de zorg wordt multidisciplinair en er ontstat cen gespecialiseerde opleiding voor groepsleiders. De nieuw opkomende inhoudelijke zorgvisie en de in de AWBZ verankerde beleidsvisie zijn vanaf 1973 niet met elkar in overeenstemming; dit creëert een spanningveld wawin doel (normalisatie en integratie) en middelen niet in overeenstemming zijn. Onder invloed van verschillen in regelgeving en departementale verantwoordelijkheid ontwikkelt zich een intra- en een semimurale sector. Samenwerking tussen beide komt onvoldoende van de grond; door het gesloten katakter van de organisaties en afzonderlijke lange wachtlijsten is er geen sprake van reële competitie tussen voorzieningen.

2. Een breed scala van beroepsgroepen doet haar intrede en zorgt voor een forse toename van beschikbare kennis. De (ortho-)pedagogiek en de psychologie worden de leidende wetenschappelijke kennisbronnen. Interdisciplinaire samenwerking is echter niet vanzelfsprekend. Het 'product' van residentiële instellingen is het bieden van een alternatief voor leven in de samenleving. Functionele organisaties vervangen de eenvoudige organisatiestructuren van vóor de $A W / B Z$ en de veelheid van nieuwe functies en beroepsgroepen leiden tot steeds complexere coördinatie; bureaucratisering neemt toe. Kennis wordt via de Z-opleiding gekanaliseerd naar de (toekomstige) medewerkers van de woongroepteams. Hierdoor komen gestandaardiseerde competenties beschikbaar in de woongroepteams. Woongroepen worden kleiner (van gemiddeld 18 naar 12 bewoners). Er ontstaan coördinerende middenkaders en staffuncties. Differentiatic van woongroc pen neemt toe (overwegend naar zorgzwaarte en leefijid) en er ontstaan sociowoningen buiten het terrein. Residentiele instellingen zijn sterk autonome, nar binnen gerichte organisaties en kennen in toenemende mate een bedrijfsmatige cultuur.

\subsection{De jaren negentig en de periode 2000 tot 2003}

\subsubsection{Achtergronden van ontwikkeling}

De jaren negentig vormen een bijzonder complexe periode vanwege de gecombineerde effecten van (1) demografische ontwikkelingen, (2) cen veranderende beleidsvisie, (3) de invoering van nieuwe wet- en regelgeving, (4) wijzigingen in de bekostigingssystematiek, (5) een klimaat van kostenbeheersing en beruinigingen, en (6) een nieuw kwaliteitsbewustzijn. 


\section{Demografische ontwikkelingen}

De algemene vergrijzing van de bevolking is ook binnen residentiele instellingen voor mensen met verstandelijke beperkingen merkbaar. Mede door de toegenomen gezondheidszorg leven mensen binnen instellingen langer en wordt het verschil met de algemene bevolking steeds kleiner (Maaskant \& Haveman, 1988; Maaskant, 1993). Dit verootzaakt mede een capaciteitsprobleem ondat instellingsplaatsen langer bezet bljiven. De ontgroening van de bevolking begon invloed te doen gelden op de arbeidsmarkt voor verzorgende beroepen, maar werd nog gecompenseerd door enerzijds een beleid van herintreders en anderzijds een rem op capaciteitsuitbreiding in de zorg. De groei van de bevolking is sterk afgenomen en vanaf 2004 kondigt zich zelfs een afname van de bevolking aan. Deze afname verschilt regional en daarmee zuilen ook arbeidsmarkteffecten regionaal verschillen; in Limburg is deze daling echter reeds ingezet (CBS, 2004; Derks, 2004a, 2004b).

\section{Veranderende beleidsvisie}

De beleidsvisie wordt nier meer gedomineerd door Normalisatie van woorzieningen, maar is gericht op emancipatie, zelfbepaling en participatie van personen mer verstandelijke beperkingen in de samenleving. In de nota Zorg en dienstzerlening aan geestelifk gebandicapten (1989), gevolgd doot de werknotitie Verstandig veranderen (1990), wordt een transformatie van residentiële instellingen voorgestaan in de richting van kleinschalige en geintegreetde huisvesting - 'wanneer dat overeenkomt met de keuze van de verstandelijk gehandicapte of zijn ouders' - maar worden gelijktijdig ook twijfels geuit over haalbaarheid en kosten. In eerste instantie leiden deze nota's tot veel discussie maar tot weinig verandering. Het meerjatenptogramma De perken te buten (1995) en vooral her Landelijk sectoral beleidstoetsingseader (1996) zijn praktischer georienteerd en stellen resoluut voorwaarden aan nieuwbouw en vernieuwbouw van inrichtingen. Deze dienen plats te vinden in kleinschalige woningen buiten het 'hoofdterrein' en door middel van woonwensenonderzoeken aantoonbaar rekening te houden met de wensen van de gebruikers. Daarmee komt een effectief deconcentratie- en integratiebeleid op gang (Overkamp, 2000). Sectorbreed wil men binnen een periode van 10 jaat 30 procent van de capaciteit van residentiële instellingen omzetten in kleinschalige woonvoorzieningen 'buiren de hoofdlocatie' en binnen de samenleving (Nederlandse Vereniging woor Gehandicaptenzorg, 1994; Somma, Nederlandse Vereniging voor Gehandicaptenzorg, Fiad-Wdt, Fedetatie van Ouderverenigingen, 1995).

De nota Actralisatio 1996 van De perken te berten gaat nog verder in op 'volwaardig burgerschap', 'maatschappelijke participatie' en 'keuzevrijheid'. Mensen met verstandelijke beperkingen dienen, als burgers van de samenleving, zoveel als mogelijk gebruik te maken van de algemene voomzieningen van de samenleving. Om deze Commanity Care te realiseren dienen wet- en regelgeving - vooral het trio AWBZ, WZV en WTG - te veranderen (Zicht op zorg, 1999), maar moet ook de samenleving 
veranderen en zich meer openstellen roor (het leveren ran diensten aan) mensen met verstandelijke beperkingen (Beraadsgroep Communiry Care, 1998).

Waar het eind van de negentiende eeuw kan worden gekarakteriseerd als en periode van institutionalisering, kan het eind van de twintigste eeuw worden gekarakteriseerd als een periode van de-institutionalisering. Bedroeg her vantal bewoners van AIV's (op het instellingsterrein) in de totale bevolking in $1995 \mathrm{nog}$ 0,192 procent, in het jaar 2000 is dit gezakt narar 0,161 en in 2002 is dit 0,154 procent. In die periode daalde het aantal bewoners van centrale AIV locaties met 17 procent. Deze de-institutionalisering staat niet op zichzelf ondat ook andere gezondheidszorgsectoren eenzelfde beeld vertonen. Zo daalde het aantal bewoners van verzorgingstehuizen tussen 1995 en 2002 met 14 procent; dat van verpleeghuizen met 23 procent; dat van de instituutlocatie van psychiatrische instellingen met 6 procent (CBS, 2004). De-institutionaliseting heeft in de residentiele zorg voor mensen met verstandelijke beperkingen echter vooral betrekking op het veranderen wan de kenmerken en de plaats van de zorg ('integratie") etn niet op cen inkrimping van de residentiële capaciteit of sluiting van instituten. Daatom is de term 'deconcentratie' hier beter op zijn plats (Overkamp, 2000).

\section{Wet-en regelgeving}

In samenhang met het discours over zorgvisie worden in de jaren negentig een groot aantal wetten ingevoerd en worden uitwoeringsregelingen van bestaande wetten aangepast. Het is niet overdreven om te stellen dat de jaren negentig de jaren van juridisering van de zorg zijn geworden.

Tabel 2.1 Ontwilkseling wan we - en tegelgeving op het tertein wan de gezondheidszorg met consequenties voot de organisatie van residentiele instellingen (1991-2003)

\begin{tabular}{|c|c|}
\hline Jrat & Wet \\
\hline 1991 & Intrekling Wet Voomieningen Gezondheidszotg (1982) \\
\hline 1992 & Wer Bijzondere Opnemingen in $\mathrm{Psychiatrische} \mathrm{Zielkenhuizen} \mathrm{(BOPZ)}$ \\
\hline 1993 & Wet Vorzieningen Gehandicapten (WVO) \\
\hline 1093 & 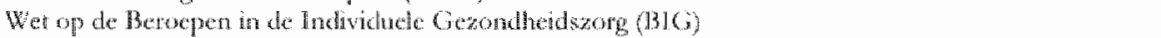 \\
\hline 1994 & Wet Mentondap ten Behoeve van Neerderjarigen \\
\hline 1994 & Wet op de Geneckandige Behandelingsowerenkonst (WCBO) \\
\hline 1995 & Wet Flachtreche Clienren Zorgsector \\
\hline 1996 & 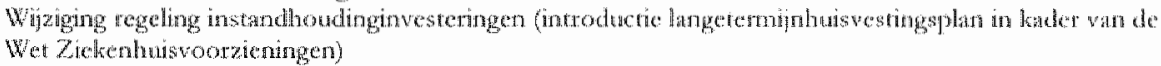 \\
\hline 1996 & Wet Medezeggenschap Clïnten Zorginstellingers (WMCZ) \\
\hline 1996 & Kualiteitswet Zorginstellingen \\
\hline 1996 & Regeting wrije matge erkemninger \\
\hline 1997 & Zorgindicatichosur (AWBZ) \\
\hline 1998 & Wer op de (ke) integratic arbedsgehandicapen (RE $A$ \\
\hline 1998 & 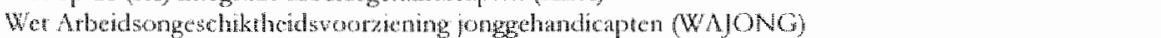 \\
\hline 1998 & We medisch weters shappelik onderzoek met mensen. \\
\hline 2009 & Wet Bescherming Porsonsgegevers \\
\hline 2000 & 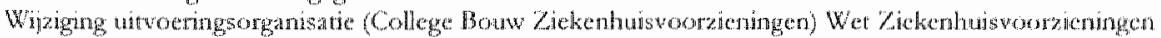 \\
\hline 2002 & 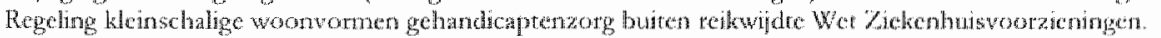 \\
\hline 2003 & 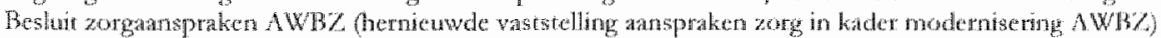 \\
\hline 2003 & 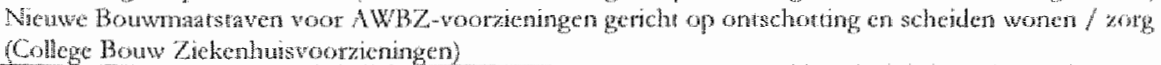 \\
\hline
\end{tabular}


Tabel 2.1 geeft cen owerzicht van nieuwe wetten en belangrijke wijzigingen in uitvoeringsegelingen die binnen een tijdbestek van enkele jaren werden ingevoetd en consequenties hadden voor de organisatie van de inhoudelijke zorg. Juridisering bracht met zich mee dat - meer dan voorheen - formalisering plaatsvond in de relatie tussen zorgorganisatie en cliënten. Beslissingen die rroeger in onderling overleg tussen professionals en met het cliëntsysteem binnen de eigen verantwoordelijkheid en in de eigen stijl van de betrokkenen werden genomen, werden nu aan exteme regels gebonden (Legemate, 1994; Dute \& Hermans, 2000 ).

\section{Bekostigingssystematiek}

In de jaren negentig van de twintigste eeuw vinden eveneens belangtijke wijzigingen plaats in de verstrekkingen-en bekostigingssystematiek van residentiele instellingen. Nadat al vanaf medio jaren tachtig op basis van substitutie op kleine schal omzetting van residentiele capaciteit naar kortverblijf of dagopvang plaatsvond, leidde de flexibilisering van de AWBZ in 1999 tot de inspanningsverplichting om 'zorg-op-mat' in te voeren. Daarbij diende ten minste 7 procent van de aanvaardbate loon- en materiële kosten van een instelling flexibel te worden ingezet ten behoeve van kort verblijf, logeren, dagopvang van buiten de instelling wonende cliënten, ambulante begeleiding en andere activiteiten. Meerkosten van deconcentratie en kleinschaligheid worden via een toeslag per gedeconcentreerde plaats gedecltelijk gecompenseerd, maar geleidelijk ook aan strenge voorwaarden gebonden: gedeconcentreetcle woningen komen uiteindelijk slechts in aanmerking voor deze toeslag wanneer het gaat om zelfstandige woningen met 6 tot 12 personen en mits deze in verschillende postcodegebieden liggen.

In 1996 ontstat een altematief voor de traditionele AWBZ-zorg in natura: het Persoonsgebonden Budget (PGB) (Cremers, 1998). Dit is een volstrekt andere bekostigingssystematick waarbij een op grond van zorgbehoefte vastgesteld budget door de persoon met een handicap zelfstandig wordt beheerd voor het inkopen van zorg bij de leverancier van zijn keuze. Dit kan trouwens ook bij een traditionele residentiële instelling. De residentiële instellingen hebben zich sterk gemaakt on een variant van het PGB in het leven te roepen: het Persoonsvolgend Budget (PVB). Anders dan bij het PGB beheert de instelling het bedrag dat op grond van indicarie en zorgzwaarte is vastgesteld (Beijer, 2000; Coolen, Geus \& Sohl, 2001). Het PGB is niet onbelangrijk voor de ontwikkeling van het wonen van mensen met verstandelijke beperkingen omdat in toenemende mate (jonge) ouders van kinderen mer vetstandelijke beperkingen initiatief nemen om zelf een woning te huren en de zorg te financieren met een PGB. In het jaar $2000 \mathrm{ging}$ het om een honderdtal initiatieven (Baarveld \& Ramakers, 2001) en dit aantal is nog steeds groeiend (Smers, 2003).

Na een periode van experimenten en onderzoek wordt in 2002 de weg ingeslagen naat zorgzwattefinanciering. Hoewel ook de traditionele AWBZ input-financiering rekening hield met factoren als 'niveau van functioneren', 'leefrijd", 'groepsgrootte' 
en blind/doof, kwam het instellingsbudget niet tot stand op grond van de individuele zorgvtaag en zorgzwaarte. De nieuwe bekostigingssystematick gaat daat wel wan uit. Per cliënt dienen zorgmodulen en zorgproducten te worden wastgesteld als basis voor de berekening van diens PVB. De instelling ontvangt dan per client het PVB dat bij zijn zorgproducten hoort (CTG, 2002). In principe wordt datardoor de zorg flexibeler en wordt verder de weg gebaand voor het scheiden van wonen en zorg (College bouw ziekenhuisvoorzieningen, 2001). Een keerzijde is dat de vaag. gerichte zorg binnen gedetailleerde productbepalingen wordt gedwongen; dir dient eerder de beheersbaarheid van de zorg dan de individualiseting en leidt tot aanzienlijke toename van administratieve taken rondom de cliënt. Deze financie-. ringsworm is tot op heden (mei 2004) nog niet operationcel.

\section{Kostenbeheersing en bezuinigingen}

Juist in een tijd van vernieuwing zette budgettaite krapte van instellingen de zorg onder druk. De regeetakkoorden voor de perioden 1994-1998 en 1998-2002 legden grote nadruk op kostenbeheersing. Dit leidde ertoe dat uitgaven vanwege de in $C A O$ 's afgesproken loonstijgingen slechts gedeeltelijk werden gecompenseerd door: inkomsten. Het verschil en de daarboven op komende extra doelmatigheidskottingen', moesten instellingen genereren uit eigen middelen. Aan de productickant vergden kleinschaliger en gedeconcentreerde woongroepen relatief meer medewerkers zonder dat een 'kleinschaligheidstoeslag' dit voldoende compenseerde. Ondertussen leidden discussies over nieuwe zorgvisies en vooral het emancipatorische 'burgerschapsparadigma' tot hoge verwachtingen die op grond van beschikbare budgetten lang niet altijd waargemaakt konden worden. Deze omstandigheden samen leidden tot stijging van de werkdruk. Dit probleem deed zich zeer pregnant voor in de dagbesteding binnen instellingen. Ondanks de extra middelen die daarvoor vanaf 1998 via verschillende beleidsregels van het CTG ter beschikking kwamen was er in 2002 nog steeds niet sprake van een bevredigende situatie (Koedoot, 1999; Wiersma, Beumer, Koedoot \& Vlaskamp, 2002).

Het Actiephan Zorg Verzekerd (Borst-Eilers, 2000) zorgde in november 2000 voor een omslag met extra gelden voor het wegwerken van wachtlijsten en voor het verlichten van werkdruk. Dat moment matkeert ook her begin van het regime van 'geclausuleerde open-einde-financiering' waarbij input-financicring van instellingen verschuift naar ouput-financiering. Hierbij wordt de controlefunctie van zorgkantoren groter en worden - zoals hierboven reeds aangegeven - steeds meer 'productspecificaties' van de geleverde zorg gevraagd hetgeen in de zorgorganisaties bijdraagt tot de versterking van een beheersklimaat.

Geleidelijk worden condities voor competitie en marlktwerking geschapen, zij het dat deze marktsituatie nog erg ambigu blijft ondat de overheid met regelgeving zowel zorgaanbieders als verzekeraars aanstuurt. 


\section{Kwaliteitszorg}

Tot slot wordt deze periode gekenmerkt door vernieuwde aandacht voor kwaliteitszorg. In hoofdstuk 4 (paragraaf 4.2) wordt hierop nader ingegaan. Hier wordt volstaan met het signaleren van wier belangrijke ontwikkelingen. Ten eerste neemt aandacht woor methodisch werken sterk toe. Individualisering, behoefte aan verantwoording en doelmatiger opzet van zorg vormen de motieven achter de ontwikkeling van individuele zorgplannen (Barnard \& Meerveld, 1992; Van Gemert \& Vlaskamp, 1997). Zorgplannen vormen een effectieve combinatie van inhoudelijke begeleidings- en behandelingsactiviteiten en kwaliteitszorg (Van Geffen, 2000). Ten tweede, het ontstaan van consulententeams waarin regionaal de bij instellingen aanwezige diagnostische en behandelingskennis wordt gebundeld en toegankelijk wordt gemaakt voor een meer effectieve behandeling van ernstig probleemgedrag. De introductie van consultatie bracht een cultuuromslag teweeg. Instellingen werden opener; vastgelopen begeleidingssituaties konden nu binnen een professioneel kader met externe deskundigen worden aangepakt (Van Gemert \& Peelen, 2001; Janssen, 2000). Ten derde deed met de Leidschendamconferenties een meer bedrijfsmatige kwaliteitszorg haar intrede. De Kwaliteitswet zorgde vanaf 1996 verder voor meer activiteiten op het terrein van kwaliteitszorg. Ten vierde verschuift vanaf het begin van de jaren negentig van de twintigste eeuw het accent van kwaliteit van zorg naar kwaliteit van het bestaan van mensen met verstandelijke beperkingen. Kwaliteit wan bestaan doet als concept recht aan de individualiteit en de waardigheid van de persoon. Het gaat niet langer om het inpassen van mensen binnen zorgprogramma's en -organisaties, maar om het aanpassen van zorg aan de individuele situatie en om de uitkomsten van zorg (Van Gennep, 1989; Schalock \& Verdugo, 2002).

\subsubsection{Organisatie}

In de jaten negentig wonden vele fusies plaats tussen zorgorganisaties. Zo nam alleen al tussen 1999 en 2002 het aantal rechtspersonen in de zorg voor mensen met verstandelijke beperkingen met 19,5\% af (tabel B2.2). Het gaat daarbij slechts gedeeltelijk - ongeveer in éénvijfde van de gevallen - over complementaire fusies tussen intra- en semimurale zorgorganisaties (Ministerie van Volksgezondheid, Welzijn en Sport, 2002). Complementaire fusies leiden in principe tot verbreding van het dienstenambod en van beschikbare expertise die alle clienten van de gefuseetde organisatie ten goede kan komen, zeker wanneer de betrokken voorzieningen in een zelfde regio liggen. Fusies vonden niet altijd vanuir deze rationale plaats. Zij betroffen niet zelden voorzieningen die niet in eenzelfde regio liggen of gelijksoortige voorzieningen (intramuraal + intramuraal; semi-muraal + semimuraal) waardoor de inhoudelijke meerwaarde twijfelachtig is. Naar de effecten van deze fusies is (nog) geen wetenschappelijk onderzoek gedaan. Het is echter onzeker of deze hebben geleid tot efficiëntere bedrijfsvoering en winst voor de directe zorg aan de cliënt. De complexere bedrijfsvoering van grote zorgotganisaties en de administratieve processen van persoonsvolgend budget en (voorbereiding van) 
zorgzwartefinanciering hebben eerder tot personeelstoename in beheersmatige functies geleid. In grotere zorgorganisaties melden medewetkers in het primaire proces een lagere arbeidssatisfactie; deze heeft geen betrekling op de inhoud van hun werk mar wel op organisatieaspecten. Uit onderzoek blijkt ook dat groepsleiders in instellingen die korter dan een jaat geleden fuseerden, significant minder tevreden zijn (Van det Ploeg \& Scholte, 1997). Sommigen maken gewag van toenemende "stroperigheid" in het functioneren van fusieorganisaties (Eggink \& Blank, 2001; Wiercx, 2001; Prismant, 2002; Maarse, 2003).

Al dan niet in samenhang met fusie vinden in de jaren negentig vele organisatieveranderingen plaats. De klassieke residentële instelling uit de jaren zeventig en tachtig van de twintigste eeuw kende cen sterk professioneel (aanbod)gestuurde en hiërarchisch opgezette dienstenstructuur. Zij was het product van de verzorgingsstaat en ontworpen om, vanuit het standpunt van de professional, goede zorg te bieden aan een bijzondere categorie mensen. Goede zorg was zorg die overeenkwam met professioncle visies en voldeed aan professionele standaarden. De bewoners waren 'lijdend voorwerp' van deze zorg: er werd voor hen gezorgd. Onder invloed van het 'vraaggerichte zorg' concept werd de cliënt met zijn eigen zorgvraag meer centraal gesteld. Daartoe moest de professionele bureaucratic worden verlaten (Diemel, 1993; Reitsma \& Van den Broek, 1999). De belangrijkste organisatieveranderingen betreffen: (1) het creëren van kleinere, integrale eenheden waarin meerdere inhoudelijke en voorwaardenscheppend functies samengebracht zijn; (2) en het toekennen van een grotere mate van autonomie en bevoegdheid aan de leiding van een dergelijke eenheid. Dergelijke teams dienen flexibeler te kunnen reageren op de uiteenlopende en veranderende zorgvtagen van de cliënten: de klantgerichte organisatie. In de praktijk is deze 'kanteling' anno 2003 nog in volle gang. Soms wordt een divisionering van de organisatie toegepast die meer is toegesneden op locaties, maar de professionele bureaucratie op kleinere schaal imiteert (figuar 2.4). Divisionering is geen synoniem voor kanteling en garandeert daarom geen klantgerichte organisatie omdat de traditionele dienstenstructuur - zij het in geminiaturiseerde vorm - maar ook centrale bevoegdheden en de instellingscultuur behouden blijven. Er ontstaat niet zelden een 'kloon' van de grotere instelling met weinig eigen strategische ruimte. Ook deconcentratie en verkleining van woongroepen garandeett geen vraaggerichte of klantgerichte cultuur. Deze kunnen zelfs leiden tot micro-institutionalisatie, waarbij de kenmerken van door professionals geregisseerde zorg volledig behouden blijven (Van Gennep, 2000).

Mede door toename en verspreiding van het aantal locaties waar de cliënten zich bevinden, is het niet altijd mogelijk alle (woon)functies die binnen de residentiöle organisatie traditioneel ' $7 \times 24$ uur' werden geleverd, ook zelf te blijven aanbieder. Voor bewoners van keine en verspreid liggende sociowoningen is het bijvoorbeeld niet mogelijk om een nachtdienst vanuit de eigen organisatie te blijven voorzien. 


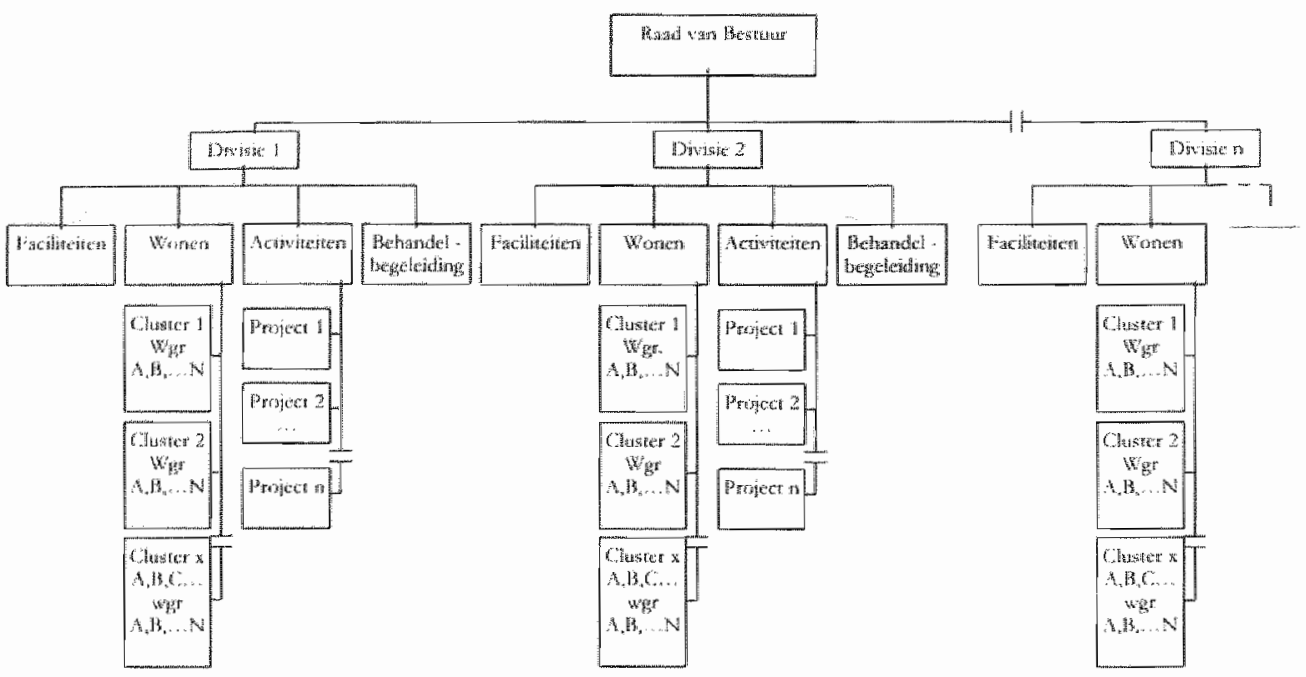

Figuur 2.4 Prototypisch organisatiemodel residentiële instelling voor mensen met verstandelijke beperkingen: ale gedivisioneetde structunt

Samenwerking met andere organisaties - bijvoorbeeld de thuiszorg - brengt dan uitkomst. Woningen waarin de cliënten gehuisvest zijn, zijn niet altijd meer eigendom van de residentiële organisatie, maar worden toenemend gehuurd van een woningcorporatie. Deze vormen van samenwerking leidden tot meer netwerkorganisaties en virtuele organisaties. Onder netwerkorganisaties wordt verstaan dat zelfstandige organisaties met elkaar op onderdelen een structurele samenwerking aangaan, meestal binnen een geografisch gebied, om daarbinnen cliënten van de residentiële instelling van de nodige diensten te voorzien. Onder virtuele organisaties wordt verstaan dat functionele eenheden zonder eigen rechtspersoon of zonder aparte fysicke locatie in het leven wotden geroepen, meestal in de vorm van een project dat wordt gefaciliteerd door verschillende techtspersonen (figuur 2.5).

In Mintzbergs termen (1983) gant het om minder geformaliseerde "ad hoc strucruren' met een hoog zelfsturend karakter. Binnen het project zijn de medewerkers gezamenlijk verantwoordelijk voor het realiseren van de doelstelling.

Fen nog recentere ontwikkeling is dat dergelijke netwerkorganisaties of virtuele organisaties hun oorspronkelijke doelgtoep overstigen en diensten aanbieden aan meerdere cliëntgroepen zoals mensen met verstandelijke en lichamelijke beperkingen en verpleeghuiscliënten. Dit wordt mogelijk gemaakt door de modernisering wan de $A W B Z$ en de algemene functionele zorgaanspraken die daarmee wotden ingevoerd (College voor Zorgverzekeringen, 2003).

Hoewel transformatieprocessen van klassieke instellingsorganisaties in enkele publicaties worden besproken (Van den Beent, 2004; Hoogma, Van Grinsven \& Wesseling, 1998; Kröber \& Van de Siepkamp, 2001), is nog geen beschrijving voorhanden van een nieuwe integrale architectuur van ondersteuningsorganisaties als alternatief voor de residentiële instelling. 


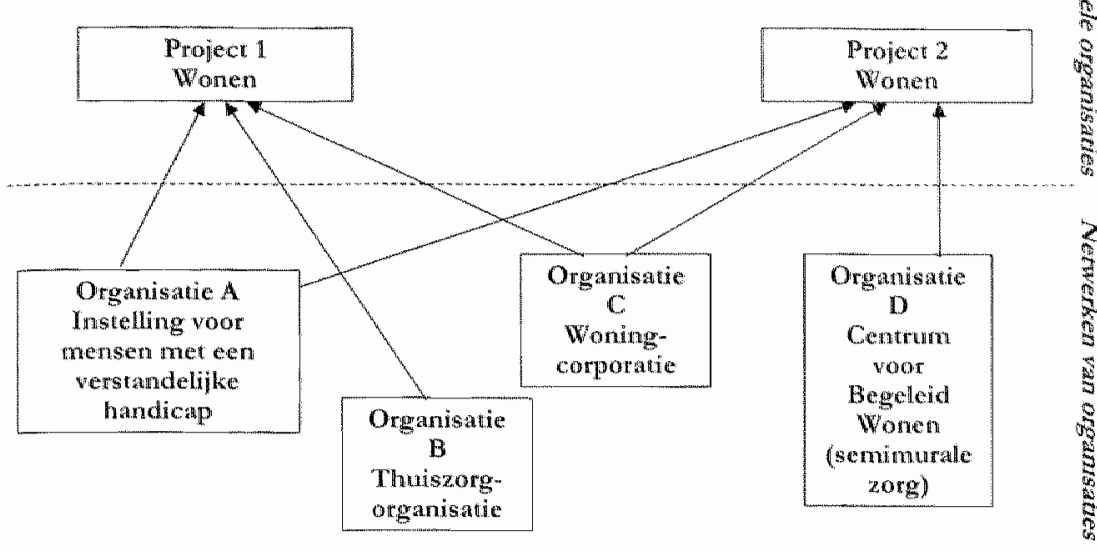

Figuu 2.5 Prototypische organisatiemodel virtuele organisaties binnen een netwerkstructuur

Aan het begin van de énentwintigste eeuw is de organisaticomgeving van residentiële instellingen (financiering, regelgeving, kennis en technologie, demografie, regionale competitie en alliantiemogelijkheden) nog steeds sterk in beweging. Daarmee samenhangend is ook de interne architectuur van residentiële instellingen nog steeds aan verandering onderhevig, en lijdt - in Mintzberg's termen - vaak aan gebrekkige consistentie en verminderde effectiviteit (Buntinx, 2000).

De geschetste externe en de interne ontwikkelingen schiepen de verwaching dat bewoners van residentiële instellingen een beter leven zouden gaan leiden onder de 'omslag' naar vraaggerichte zorg. Door de beschreven problemen veranderde voor de meeste bewoners - vooral met ernstige verstandelijke beperkingen - in de praktijk maat weinig met betrekking tot groepsgrootte (deze bleef in de beschouwde periode gemiddeld 10), beschikbare groepsleiding en activiteiten. Deze discrepantie leidde tot bezorgdheid over de

kwaliteit van zorg bij ouders en familie. Daarbij komt dat verdeeldheid ontstond bij ouders en familie van bewoners van instellingen over de wenselijkheid wan verdere of complete deconcentratie en van Community Care Verontruste familieleden bij intramurale instellingen voor verstandelijk gehandicapten, 1999; Van Gennep, 2002a \& 2002b; Voorberg, 2003).

Taakverdeling en coördinatie binnen de woongroepteams veranderden in deze periode door de bredere introductie van een aparte huishoudelijke functie en het vormgeven aan het 'persoonlijk begeleiderschap'. Naast een functionele takverdeling was in de residentiële zorg reeds langer een persoonlijke toewijzing van cliënten aan begeleiders - zeker in woongroepen van kinderen - niet ongebruikelijk. Dit was een pedagogisch inhoudelijke aangelegentheid (om commitment van groepsleiders en gehechtheid te bevorderen) die teruggevoerd kan worden op ervaringen in het begeleiden van residentiële kindergroepen tijdens de tweede wereldoorlog. 
Observaties in residentiele settings hadden uitgewezen dat de ontwikkeling van jonge kinderen gunstiger verliep wanneer leidsters enkele vaste kinderen knigen toegewezen dan wanneer zij de aandacht over de hele groep verdeelden. (Burlingham \& Freud, 1943; 1947). Het persoonlijk begeleiderschap heeft een organisatorische oorsprong en is geinspireerd op de principes van het 'case management". Case management beoogt coördinatie, integratie en continuitteit van complexe hulpverlening rond het individu (Goudriaan, 1989; Maes, Bruyninckx \& Goffart, 2003). Als leidraad daartoe dienen individuele zorgplannen. In de residentiële zorg woor mensen met verstandelijke beperkingen verwijst 'persoonlijk begeleiderschap' over het algemeen naar de coördinerende taken van een teamlid rond éen of meerdere individuele cliënten, binnen do context van de eigen voorziening. Dat wil zeggen dat persoonlijke begeleiders vaak de organisatorische bevoegdheden en faciliteiten missen on individuele arrangementen in een bredere maatschappelijke context (community care) te realiseren; de invulling beperkt zich dan niet zelden tot administratieve taken (zoals 'zorgplan bijhouden') en onderhouden van contacten met familic (Buntinx, 1998). In sommige gevallen is de takomschtijving breder en maakt een 'persoonlijk assistent' geen deel uit van het team maar functioneert meer als case manager (Van Loon, 2001; Van den Beemt, 2004).

Samenvattend kan deze periode als volgt worden gekarakteriseerd:

1. Emancipatie, participatie en keuzemogelijkheden van mensen met functioneringsbeperkingen zijn de elementen van de dominante beleidsvisie. Daardoor ontstaat een trend naar meer individualisering. Het 'product' van de instelling verschuift langzaam van zorg naar 'ondersteuning'; ondersteuning is gericht op het benutten van hulpbronnen, waar mogelijk van hulpbronnen in de natuurlijke omgeving van de persoon en van algemeen maatschappelijke hulpbronnen (community care), waarmee condities kunnen worden gecreëerd voor een kwalitatief goed bestaan. Daarnaast wil de overheid haar eigen rol terugdringen en markiwerking toelaten. Financiele middelen nemen af terwijl juist relatief dure vernieuwing (deconcentratie, individualisering moet worden gerealiseerd. Op beleidsniveau leidt het emancipatiestreven tot een hausse in nieuwe wet- en regelgeving. Nieuwe financieringsvomen ontstaan (PGB en zorgzwaartefinanciering) en kwaliteit is niet langer alleen een aspect van het handelen van individuele professionals maar wordt een aspect van organisatie en management. De Z-opleiding verdwijnt en bestaande opleidingen leiden niet rechtstreeks meer op voor beroepen in de zorg voor mensen met verstandelijke beperkingen ontstaat. Demografisch kriigen residentiele instellingen te maken met een sterke vergrijzing van hun cliëntenpopulaties; er wordt meer beroep gedaan op oudere werknemers via stimulering van herintreders. Onder invloed van de modernisering van de $A W B Z$ is ex een begin van competitie tussen organisaties, maar traditionele patronen, wachtlijsten en het nog relatief ontbreken van nieuwe aanbieders, vethinderen feitelijke concurrentie op de markt van cliënten. Er is sprake van een de-institutionaliseringstendens in de gehele gezondheidszorg. 
2. Fusies, deconcentratie, reorganisaties, invoering wan nicuwe regelgeving en orièntatie op de nieuwe beleidsvisie doen de functonele organisaties (professionele bureaucratieèn) langzam verdwinen. Darmoot in de plats komen wooral gedivisioneerde en in mindere mate ook klantgerichte organisaties. Er ontstan langzamethand netwerkorganisaties en vituele ongnisaties. Fi is nog weinig congruentie tussen organisatiestructuren en de wijzigende maar nog niet uitgekristalliseende regelgeving (bijvoorbeeld: viaggestuurde bekos tiging. Een beheersmatige cultur kleurt het inhoudelike zorgklimaat door het gecombineerde effect van externe regelgeving, budgettaire krapte en kwaliteitszorg (protocollering). Methodisch werken heeft via zorgplannen bteed zijn intrede gedaan. Al deze veranderingen verlopen weinig synchroon en leiden tot inconsistenties binnen organisaties. Daabij bliven traditionele organisatiepatronen vaak op woongroepniveau gehandhaafd waaronder vooral de koppeling tussen klleinete woongroepen (van 9 à 10 tot 8 , 6 en 4 bewoners) en (kleine) woongroepteams. Coördinatie van zorg verloopt langzamerhand meer 'resultartgestuurd' op basis van individuele zorgplannen en via 'persoonlijk begeleiders', maat dicht bij de cliēnt beschikken medewerkers nog steeds over weing bevoegdheden.

\subsection{Personeelswisselingen in historisch perspectief}

Personeelswisselingen zijn geen nieuw verschijnsel. Buitenlandse pioniers van professionele zorg voor mensen met verstandelijke beperkingen beklaagden zich in de negentiende eeuw teeds over het grote verloop van medewerkers. Dit achtten zij een belangrijke belemmering voor de implementatie en voor het succes van pedagogische programma's (Baumeister \& Zaharia, 1987; Freund, 2001; McIntire, 1954). In Nederland lag het vetloop rond de wisseling van de negentiende en de twintigste eeuw bij 's Heeren Loo laag, maar rond de jaren twintig was her aanzienlik: de gemiddelde dienstrijd van de 'zusters' was toen twee jaar en elf manden. De verklaring hiervoor moet wotden gezocht in de arbeidsvoorwarden en werkomstandigheden: lage salarissen, lange werkdagen (van elf tot negen uur), te weinig vakanties en te lang aaneengeshoten werkperioden. In de jaren dertig leidden verbetering van deze omstandigheden tot aanzienlijk minder problemen bij werving en behoud wan personeel. Een andere verklaring voor het hoge verloop lag in de periode tussen de twee wereldooriogen in het feit dat het werken bij zwakzinnigen eerder werd gezien als een opstap nat een $A$ - of B-diploma en dat meisjes dic dit werk deden daamee stopten zodra ze in het huwelijk traden. Her inwerken van telkens weer nieuwe medewerkers die niet lang bleven werd duidelijk als probleem erwaren (Jak, 1993). Daarentegen bleven hoofdzusters die de leiding over een pavijoen hadden veel langer en meestal tot hun pensionering in dienst (jak, 1999). Vanwege het kloostersysteem waarbij voor de zusters en broeders leven en werken op dezelfde locatic met elkaar verbonden waren, was het verloop bif katholieke instellingen met uitsluitend religieuzen als medewerkers zoals ondermeer bij Sint 
Anna en Sint Joseph te Hecl laag. De continuiteit van de afdelingsbezetting was groot (Klijn, 1995).

In de periode wan eind negentiende eeuw tot de jaren wijftig van de twintigste eeurw stelt Freund (2001) eveneens fluctuaties vast in de diensttijd en het verloop van het (leken) personeel in vijf Zwitserse residentiële instellingen voor jeugdzorg. Gemiddeld bedroeg de duur van de diensttijd in deze instellingen ongeveer 2,5 jaar; het verlooppercentage bedroeg in die periode tussen 25 en 50 procent op jaarbasts.

Historische studies maken geen melding van personeelswisselingen op andere gronden dan verloop. Omdat woongroepen in de context van het paviljoen of afclelingensysteem erg autonoom waren, lagen overplaatsingen tussen groepen minder voor de hand. Historische studies brengen verloop in verband met factoren als (1) het aanzien van het werk, (2) de arbeidsomstandigheden, (3) de arbeidssatisfactie en motivationele factoren, (4) de beloning, (5) de arbeidsmarkt, en (6) inconsistentie tussen zorgvisie en zorgpraktijk (Klijn, 1995; Jak, 1999; Freund, 2001; Baumeister \& Zaharia, 1987). Met deze laatste factor bedoelt Freund de discrepantie tussen de visie van de instelling die groepen naar een gezinsmodel ('gezinsvervangend') beoogt te bieden, en de praktijk van een professionele organisatie die in belangrijke mate een bedrijfskatakter heeft waarbij verloop inherent is. Juist omdat verloop een belemmerende factor is voor het realiseren van zorgvisies, verdienen het ontwerp van zorgsystemen, van zorgorganisaties en de maatschappelijke waardering woor het wetk van groepsleiders grote aandacht (Lakin, Bruininks, Hill \& Hauber, 1982). In een beschouwend artikel over vijftig jaar onderzoek naar verloop van groepsleiders wijzen Hall en Hall (2002) erop dat verschuiving van zorgvisie gepaard gaat met verschuiving in het type groepsleider - of in termen wan het huidige ondersteuningsparadigma: 'ondersteuner' - en de daarbij horende competenties. Dat betekent dat personeelsbeleid en in bijzonder opleiding, selectie en beloning aangepast moeten worden aan de eisen van veranderende zorgvisies en de daarbij horende technologie. Institutionele zorg vereiste volgens Hall en Hall bijvoorbeeld punctucle en meegaande 'karakters' terwijl ondersteuning beroep doet op zelfstandigheid en medewerkers die handig zijn bij het inzetten wan hulpbronnen uit de (natuurlijke) omgeving. Discongruentie tussen de eisen van de zorgvisie en de competenties of verwachtingen van de groepsleiders kunnen, zeker in tijden van organisatorische verandering, bijdragen tot zowel verloop als personeelswisselingen. Zorgwisie, Homan Reroumes Management en inhoudelijke ondersteuningstechnologie zijn in de gezondheidszorg veelal gescheiden verantwoordelijkheden; de kwaliteit van dienstverlening is echter gebaat bil een goede afstemming (Van Erp, 1989).

In historische bronnen wordt nergens specifieke informatie over personeelswisselingen aangetroffen. Het aspect 'verloop' wordt wel gesignaleerd en in verband gebracht met conjunctuur (arbeidsmarkt, beloning), imago (maatschappelijke waatdering, verwachtingen van het werk), sociaal-culturele factoren (stoppen met werken bij huwelijk). Hoog verloop wordt algemeen beschouwd als schadelijk voor de consistentie en de effectiviteit van de organisatie. 


\subsection{Residentiële instellingen: de huidige Nederlandse situatie}

Aan het begin van de $21^{\circ}$ eeuw zijn er in Nederland 133 algemene residentiele instellingen voor mensen met verstandelijke beperkingen met in totaal 33.694 platsen (CTG, 2002). Tabel 2.2 geeft hiervan een aantal kerngegevens weer. In 2002 wonen ruim 37 procent van alle bewoners van algemene instellingen buiten de hoofdlocatie, in een gewone strat (tabel B2.3). Het beleidsdoel uit 1995 is daarmee in principe bereikt. In de jaren zeventig waren residentiële instellingen overwegend gehuisvest op één terrein. De gemiddelde om wang was rond 300 bewoners. In 2002 bestaat een residentiële instelling uit verschillende en verspreid liggende locaries warbij het gemiddelde aantal bewoners per locatie (postadres) thans nog 33 bedragt (tabel B2.4). Het deconcentratieproces is nog steeds in volle gang en het aantal bewoners van AIV's dat in de lokale samenleving woont neemt nog steeds toe (Van Daal, 2003). In 2000 woont eenderde van de bewoners van residentiele instellingen in groepen van minder dan zes bewoners; eenderde woont in groepen van zeven tot negen bewoners; eenderde woont in groepen van tien of meer bewoners (Vereniging Gehandicaptenzorg Nederland, 2002).

Over personeelswisselingen bestaan geen cijers; er is wel informatie over verloop. Terwijl het verloop van groepsleiders in residentiële instellingen in de eerste helft van de jaren negentig van de twintigste eeuw stabiel rond 12 procent lag, nam het in de tweede helft toe tot 21 procent in het jaar 2000 (tabel B7.2).

De historische schets in dit hoofdstuk illustreert dat de configuratie van de residentiële instelling aan complexe invloeden onderhevig is. Deze kan niet eenvoudig vanuit een 'visie' concept worden verklaard. Om doelen en visies te realiseren is de organisatie afhankelijk wan demografische, economische, juridische en regeltechnische, technologische (beschikbare kennis) en competitieve factoren. De interne en externe effectiviteit van een concrete organisatie hangt af van enerzijds de binnen externe regelgeving en omstandigheden beschikbare ruimte en anderzijds de inventiviteit en flexibiliteit om met beschikbare technologie zo goed mogelijk aan de behoeften van chëntengroepen tegemoet te komen.

Door complexe externe veranderingen staan residentièle instellingen onder druk. Hun interne organisatie moet aangepast worden aan de nieuwe eisen die woortvloeien uit inhoudelijke veranderingen (zorgvisie en verwachtingen van cliènten), beleidsmatige veranderingen (wet- en regelgeving), veranderingen in do financieringssystematiek (functie- en zorgzwaattefinanciering; verhoogde marktwerking) en door demografische veranderingen (vergrijzing, ontgroening, afname bevolkingsgroei) worden gesteld. Door de gelijktijdige inwerking van deze invlocden en door een natuurlijke inertie van het systeem (nict alle afspraken en gewoonten gaan meteen om) staat de interne consistentie en daarmee de effectiviteit van organisaties onder druk (Ginter, Swayne \& Duncan, 1998, hfst. 1; Teulings, $1993)$. 
Personcelswisselingen zijn een bron van inconsistentie op het niveau van de basiseenheid van de organisatie en dus het dichtst bij de cliënt. Zij doen zich voor in de interface russen client en systeem: de plaats waat de zorg aan de cliënten daadwerkelijk tot stand komt.

Een deel van de personeelswisselingen is in ieder geval van alle tijden. Dit hangt samen met conjunctuurfactoren in de arbeidsmarkt en de positie daarin van zowel de gehandicaptensector in het algemeen als specifieke instellingen. Maar een ander deel wordt intern bepaald door de wijze waarop de begeleiding is opgezet (organisatic) en wordt gemanaged. Het niet onderkennen of verwaarlozen van dit beinwloedbare deel van personeelswisselingen trekt een extra wissel op consistentie en effectiviteit. De historische schets laat zien dat de organisatie van de interface tussen instelling en cliënt in de loop van de tijd veranderde qua omvang (groepsverkleining), context (van relatief zelfstandige afdelingen naar onderdelen van paviljoenen en clusters), locatie (van instellingsterrein naar samenleving) en enigermate qua functionele samenstelling (persoonlijk begeleiderschap, veelal echter binnen de bestaande teamstructuur). Desondanks bleef de koppeling tussen woongroep en woongroepteam structureel nagenoeg onveranderd. Een ander kenmerk is dat de structuur, samenstelling en interne regels (roosters, beloning, coördinatie) van cen woongroepteam nauwelijks verschilt naargelang de doelgroep clie zij bedient; er is binnen een residentiele organisatie juist sprake van een hoge mate van standaardisering van de teamstrucruur.

Het is nuttig inzicht te verwerven in de samenhang tussen personeelswisselingen en interne organisatiekenmerken. Het is eveneens nuttig te kijken naar effectiviteitscondities van woongroepteams en door cliënten ervaren kwaliteit van begeleiding in relatie tot personeelswisselingen. In de twee volgende hoofdstukken zal eerst aandacht worden besteed aan de literatuut over verloop en personeelswisselingen, en vervolgens aan teameffectiviteit en kwaliteitszorg binnen residentiële instellingen. 
Tabel 22 Compilatie wan lerngegevens van algemene instellingen voor verstaidelithe gehandicapten $(\mathrm{AP})^{\circ}$

\begin{tabular}{|c|c|c|}
\hline Orderengerp & Aantal & Bron \\
\hline Capaciteit toegeloten algemene instidlingen & 33.694 & 1 \\
\hline Toral aantal arbeidsplaarsen $(\mathrm{T} T \mathrm{E}$ ) & 36.502 & 2 \\
\hline Tonal antal werknemers & 540.00 & 2 \\
\hline Totnal tantal gesubsidicerde arbeiosplatisen (ID) & 1.045 & 2 \\
\hline Totan antal direct clientgebonden modewerkers & 45.219 & 2 \\
\hline Antal partume medewerters clièntgebonden & $37.545(8.5 \%$ & 2 \\
\hline Arbeidsplatsen gropsleiding (wonen) (FTE) & 22.728 & 2 \\
\hline Aancal medewerkers groppleiding (woten) & 34.77 & 2 \\
\hline Aantal patrtime medewerkers groepsleiding (woneny & $28.841(88 \%$ (40) & 2 \\
\hline Gemicheld ziekteverampercentage (excl axangerschap) & $7,7 \%$ & 2 \\
\hline Gemiddel verlow cliengebonden medewerkers & $18,5 \%$ & 3 \\
\hline Financëel kader instellingen (miliat $\theta$ ) & $2+4$ & 4 \\
\hline Percenage wan totale uitgaven gehandicaprensector & $50^{\circ} \%$ & 6 \\
\hline $\begin{array}{l}\text { Geniddelde leet } 1 \text { d bewoners } \\
\text { Ouder dan } 65 \\
\text { Jonget dan } 19\end{array}$ & $\begin{array}{l}38 \text { jant } \\
8 \% \\
11 \%\end{array}$ & 5 \\
\hline Gemidklde verblifirdure & 18 jatr & 5 \\
\hline $\begin{array}{l}\text { Mate van verstandelijke beperthing } \\
\text { Lich } \\
\text { Matig } \\
\text { Ensig } \\
\text { Zect crnstig }\end{array}$ & $\begin{array}{l}12 \% \\
33 \% \\
310 \% \\
24 \%\end{array}$ & 5 \\
\hline $\begin{array}{l}\text { Mobiliceit } \\
\text { Niet-strobulant } \\
\text { Semh-ambulant } \\
\text { Ambulant, indien gelijhwoers } \\
\text { Ambulant }\end{array}$ & $\begin{array}{l}12 \% \\
11 \% \\
11 \% \\
66^{\circ} \%\end{array}$ & 5 \\
\hline Gedmgeproblemen & $35 \%$ & 5 \\
\hline Onder bewind of tonder curatele gesteld & $73 \%$ & 5 \\
\hline $\begin{array}{l}\text { Grootre woongroep } \\
4 \text { of minder } \\
5 \\
6 \\
7 \\
8 \\
9 \\
10 \\
11 \\
12 \text { of mert }\end{array}$ & 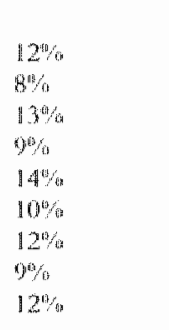 & 5 \\
\hline Wistronna & $4,6^{6} ; 5$ & 5 \\
\hline Opmane: & $5,30 \%$ & 5 \\
\hline
\end{tabular}

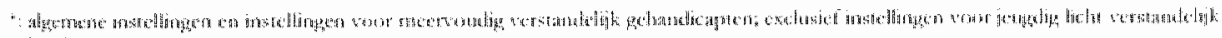

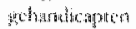

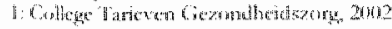

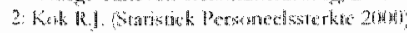

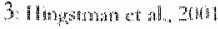

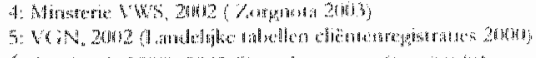

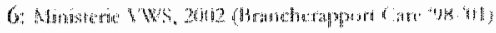





\section{Personeelswisselingen}



In dit hoofdstuk wordt de literatuur verkend over personeelswisselingen in woongroepteams van residentiële instellingen woor mensen met verstandelijke beperkingen. In paragraaf 3.1 gaat het om de vraag: 'wat wordt over het verschijnsel personeelswisselingen als praktijkprobleen gerapporteerd en welke betekenis wordt eraan toegekend ?' Bij deze eerste vrang worden zowel de vakliteratuur als de wetenschappelijke literatuur geraadpleegd (zie verder) en wordt zowel naar publicaties over 'verloop' of 'personeelswisselingen' gekeken als naar publicaties over 'kwaliteit van zorg' waarin deze begrippen als verklarende of beinvloedende factor vermeld worden. Daarbij worden de antwoorden geordend volgens het perspectief van (1) de bewoner, (2) de ouders en familie wan bewoners, (3) professionals en de brancheorganisatie; er wordt afgesloten met een conclusie (4). In paragraaf 3.2 luidt de vraag: "wat zijn de belangrijkste bevindingen van empirisch wetenschappelijk onderzoek naar personeelswisselingen?' Bij deze tweede vraag wordt specifiek gezocht naar (1) fundamenteel onderzoek over het verband tussen teamwisselingen en teameffectiviteit, naar (2) praktijkgericht onderzoek naar het verband tussen verloop en kwaliteit van zorg, naar (3) in praktijkgericht onderzoek aangetoonde correlaten van personeelswisselingen en tot slor (4) naar operationaliseringen van het concept "personeelswisselingen'. Voor de beantwoording van deze tweede vraag word uitsluitend wetenschappelijke literatuur geraadpleegd. De besproken literatuur wordt betrokken uit een eigen database van 'kwaliteit van zorg' publicaties in wetenschappelijke tijdschriften (tabel B3.1), landelijke en internationale vakbladen en overheidspublicaties. Deze selectie werd aangevuld met een literatuur search op W1 publicaties in de database PsycINFO aan de hand van de zoektermen uit tabel B3.2. De tweede paragraaf wordt eveneens afgesloten met een conclusie (5).

\subsection{Personeelswisselingen als praktijkprobleem}

\subsubsection{Het perspectief van de bewoner}

Rapportages van ervaringen van bewoners van residentiële instellingen met betrekking tot personeelswisselingen zijn weinig voorhanden. Dit komt medc ondat instrumenten voor het peilen van persoonlijke ervaringen van mensen met verstandelijke beperkingen nog weinig beschikbaar zijn. Rapporten van kwaliteitsprojecten waarbij mensen met verstandelijke beperkingen persoonlijk worden geinterviewd (zoals bij de stichting Perspectief), zijn instellingsgericht en niet openbaar. Gepubliceercle interviews over ervaringen van cliënten van residentiële instellingen met groepsleiders illustreren de afhankelijkheid wan mensen met verstandelijke beperkingen van hun professionele ondersteuners en onderstrepen het belang van goede en continue relaties tussen bewoners en professionele begeleiders (Kooyman, 2000; Whiteman \& Jaskulski, 1996).

Test, Flowers, Hewitt en Solow (2003) tapporteren dat mensen met verstandelijke beperkingen emotionele problemen ervaren naar aanleiding van verloop van hun begeleiders. Begeleiding komt tot stand binnen een dialoog tussen zorgvrager en 
zorgbieder. Het voeren van deze dialoog veronderstelt bekendheid en vertrouwdheid tussen groepsleiders en cliënten; continuiteit is in dit verband een voorwaarde voor het respecteren en bevorderen van de zelfstandigheid van mensen met verstandelijke beperkingen (Meininger, 1998; Roelink, Pool \& Grypdonck, 2002; Vlaskamp \& Verkerk, 2000). In een evaluatiestudie over trajectbegeleiding rapporteren cliënten als belangrijkste verwachting naar professionele begeleiders dat men stceds moet kunnen terugvallen op iemand waarin men zijn vertrouwen stelt. Aan continuiteit van begeleiding hechten zij veel belang (Maes, Bruyninckx \& Goffart, 2003).

\subsubsection{Het perspectief van ouders en familie}

Jaskulski \& Whiteman (1996) rapporteren dat ouders en familie van mensen met verstandelijke beperkingen in tesidentiële settings een speciale relatie hebben met de groepsleiding die hun familielid begeleidt en met wie zij hun vragen, zorgen en wensen met betrekking tot hun familielid bespreken. Vertrouwen speelt daarbij een grote rol. Ouders en familie moeten het vertrouwen hebben dat hun familielid inderdaad de zotg kriigt die nodig is en die is afgesproken in het individuele zorgplan. Zij moeten ook het vertrouwen hebben in de goede bejegening van hun familielid. Een zekere continuiteit van gtoepsleiders is een voorwaarde om dit vertrouwen te verkrijgen en te behouden.

In Nederland signaleren ouderorganisaties hun zorgen over personeelswisselingen voor de kwaliteit van zorg en beklagen zich in beleidsnota's over de hardnekkigheid van dit probleem (WOI, 1994; Van der Zwan, Spijker \& van Borssum Waalkes, 1994). Zij zien relatie, interdependentie, dialoog en continuïteit als kwaliteitsstandaarden voor professionele ondersteuning (Vereniging Gehandicaptenzorg Nederland \& Federatie van Ouderverenigingen, 2002).

In een onderzoek naar de kwaliteit van bestaan van bewoners in Nederlandse instellingen rapporteren Vreeke, Janssen, Resnick en Stolk dat de geringe stabiliteit van het begeleidingsteam bij 33 procent van ouders en bewonets tor grote ontevredenheid leidt (1998, p.120). Ouders van kinderen met chronische aandoeningen rapporteren het gebrek aan continuiteit van zorg ('steeds hetzelfde verhaal moeten vertellen' en gebrek aan coördinatie tussen behandelaars onderling) als belangrijk knelpunt woor goede zorgverlening en voor maatschappelijke participatie (Chronisch zieken en Gehandicapten Raad Nederland, 2001). In een kwalitatief onderzoek naar zorgvragen van mensen met verstandelijke beperkingen wordt discontinuifteit waaronder het vele wisselen van directe dagelijkse zorgverleners door betrokkenen zelf en hun familie expliciet als belemmering genoemd voor het tealiseren van vaaggerichte zorg (Huizing, Maaskant, Hamers \& Groot, 2002).

\subsubsection{Het perspectief van professionals en brancheorganisatie}

Schuring, Barnhard, Kardaun, Kramer en Schoep (1990) signaleren in een landelijke inventarisatie van probleemsituaties rond bewoners van residentiele instellingen het belang van kwantiteit, kwaliteit én continuïteit van de personeelsbezetting. Dit 
onderzoek - dat werd gehouden naar aanleiding van Kamervtagen over de situatie wan werstandelijk gehandicapten met emstige gedragsstoomissen - wijst erop dat het wegvallen van vertrouwde personen waaraan de bewoner gehecht is en de onzekerheid rond nieuwe medewerkers voor veel bewoners niet te bevatten is en een negatief effect heeft op het gedrag. Het vragstuk van instabiliteit van de bezetting krijgt een aparte plats bij de aanbevelingen van dit rapport. In een rapport over bejegening van bewoners in residentiele instellingen beschouwt de Nederlandse Vereniging Gehandicaptenzorg personeelswisselingen als risicofactor voor een goede bejegening (Nederlandse Vereniging Gehandicaptenzorg, 1993). Professionele behandelaars en groepsleiders noemen de instabiliteit van het woongroepteam als risicofactor voor het vóórkomen van zelfverwondend gediag (Inspectie voor de Gezondheidszorg, 1996; Nissen \& Haveman, 1997) en als belemmering voor professioneel functioneren (De Ruyter, 1995). Groepsleiders zelf rapporteren in een onderzoek naar de kwaliteit van bestaan van bewoners van Nederlandse instellingen dat meer dan eenderde hun begeleiders minder dan twee jaar meemaakt ( $V$ reeke, Janssen, Resnick \& Stolk, 1998, p. 99).

Vanuit het perspectief van bedrijfsvoering krijgt 'verloop' binnen residentële zorgorganisaties vanaf het begin van de jaren negentig steeds meer aandacht (Pool, Meeuwsen \& Michels, 1992; Ginunveld, 1999). Mede vanwege toenemend verloop en uitstroom van groepsleiders uit de sector staan het behoud van medewrerkers en het bevordeten van de aantrekkingskracht van het beroep vanaf 2000 in het middelpunt van de belangstelling. Studies identificeren factoren als werkdrukbeheersing, persoonlijke ontwikkeling, communicatie en informatie, salaris en leiderschapsstijl als speerpunten voor beleicl van personeel binnen de gezondheidszorg in het algemeen en binnen instellingen in het bijzonder (Prismant, 2002). Het overheidsbeleid ondersteunt dit beleid via arbeidsmarktconvenanten. Deze omvatten specifieke maatregelen op het tertein van beheetsing ziekteverzuim, arbeidsomstandigheden, imagoverbetering en regionaal arbeidsmarktbeleid (Ministerie van Volksgezondheid, Welzijn en Sport, 2002; Vereniging Gehandicaptenzorg Nederland, 2002).

\subsubsection{Conclusie}

Alle bij de zorg voor mensen met verstandelijke beperkingen betrokken partijen erkennen het belang van continuiteit in de relatie tussen residentiële cliënten en hun professionele begeleiders en het problematische katakter van personeclswisselingen. Organisatorische continuiteit is volgens hen een belangrijk aspect van kwaliteit van zorg. Instabiliteit wan het begeleidingsteam wordt gezien als risicofactor voor het ontstaan of voortbestan van gedragsproblemen. Hoewel het probleem regelmatig werd gesignaleerd, blijkt alleen het aspect 'verloop' wanaf de jaren negentig aandacht te ksijgen. Over (effecten van) maatregelen tegen niet door verloop veroorzakte personeelswisselingen wordt in de vakliteraturur niet gerapporteerd. 


\subsection{Personeelswisselingen als wetenschappelijk probleem}

Werenschappelijk onderzoek naar personeelswisselingen kan worden verdeeld in fundamenteel en praktikgericht onderzock. In paragraaf 3.2.1 worden publicaties mer betrekking tot fundamenteel onderzoek besproken. Daarna worden twee groepen praktijkgericht onderzoek onderscheiden. De eerste groep (paragraaf 3.2.2) beschrifft het verband tussen verloop of personeelswisselingen en 'kwaliteit van zorg' factoren. Hieronder vallen ook onderzoeken naar effecten op bewoners. De tweede groep (paragraaf 3.2.3) betreft correlaten of voorspellers van verloop of personeelswisselingen. Binnen deze tweede groep worden twee typen onderzoek onderscheiden: (1) onderzoek op niveau van de organisatie en (2) onderzoek op het niveau van woongroepen. Het eerste type betreft meestal de arbeidsrelatie: de relatie tussen groepsleiders als werknemers en de organisatie als werkgever. Het tweede type wordt uitgevoerd vanuit het bewonersperspectief en richt zich meer op de relatie tussen groepsleiders en bewoners. Tot slot wordt geinventariseerd op welke manier de begrippen 'verloop' respectievelijk 'personeelswisselingen' in deze onderzoeken werden geoperationaliseerd (paragraaf 3.2.4).

\subsubsection{Verband tussen personeelswisselingen en teameffectiviteit}

Hoewel er veel onderzoek beschikbart is over groepsdynamica (interacties in kleine groepen met $N=2$ tot $N=12$ à 20 ), zijn er nauwelijks onderzoeken naat de effecten van wisselingen van groepsleden op de effectiviteit van groepen in werksituaties. Uitzondering hierop is het werk van Holly Arrow en Joseph McGrath. Zij ontwikkelden een theoretisch kader voor de studie van temporele aspecten van kleine arbeidsgroepen en verrichten op basis hiervan experimenteel onderzoek. Hierna worden eerst de elcmenten en de structuur van hun theoretisch kader besproken; vervolgens wordt kort verwezen nat enkele experimentele studies.

\section{Theoretisch kader voor de studie wan de dynamiek van kleine arbeidsgroepen}

Arrow en McGrath (1995) definiëren een groep als een complex patroon van terugkerende relaties tussen groepsleden, instrumenten en taken. Groepen worden bepaald door (1) de onderlinge relaties en interacties tussen de leden, (2) door gebruikte instrumenten en procedures waatonder ook atritudes, gewoonten, communicatiemiddelen (kottom: technologie) en (3) door hun taken en de output of de resultaten die daatbij worden verwacht.

In de temporele struchur van groepen onderscheiden zij 'membership continuity" en 'membership change'. Continuiteit verwijst naar de stabiliteit van de groepssamenstelling en van de relaties tussen de groepsleden. Veranderingen verwijzen naar fluctuaties in de groepssamenstelling en van de relaties tussen de groepsleden als gevolg van de toctreding van nieuwe leden. Beide kenmerken kunnen vatiëren van 'frozen rigidity' tot 'sadical discontinuity'. Andere temporele aspecten zijn: duur 
van het groepslidmaatschap, moment van teamwisselingen in de context wan de groepsontwikkeling en regelmat in teamwisselingen.

Een ander kenmerk van groepen berreft het onderscheid tussen "acting" en 'standing' groepen. Een 'acting group' wordt gevormd door de relaties tussen groepsleden op het moment van (intet)actie; bijvoorbeeld, groepsleiders tijdens hun dienst. Een 'standing group' wordt gevormd door de relaties tussen alle leden en bestat ook buiten het moment van directe actie; bijvoorbeeld, een woongroepteam inclusief de leden die geen dienst hebben, viij hebben of ziek zijn.

Arrow en McGrath onderscheiden vier typen arbeidsgroepen.

- Clubs: de nadruk ligt op informele relaties; de leden komen in actie op het moment en op de wijze dat zij dat zelf nodig vinden. Eigenlijk gaat het hier nier om formele arbeidsgroepen, maar binnen organisaties kunnen wel "clubs' bestaan.

- Task forces: de nadruk ligt op het te bereiken resultaat dat bepalend is voor de samenstelling, de interacties en de technologie van de groep. Wanneet het resultat is behaald, houdt cle groep op te bestaan. Voorbeelden zijn: een onderzoekscommissie, een projectream.

- Crews: de nadruk ligt op de technologie voor het uitvoeren van een in de tijd afgebakende opdracht. De leden voeren gespecialiseerde taken uit en werken vaker in wisselende samenstellingen warbij de positie in de groep wordt bepaald door de eigen deskundigheid. De groepssamenstelling eindigt bij het uitvoeren van de opdracht. Voorbeelden zijn: een wliegtuigbemanning, een operatieteam.

- Teams: de nadruk ligt op de interactie tussen de leden en de gebruikte technologie. Groepsleden beschikken over specifieke competenties (vaardigheden) die zij in wisselencle taken inzetten, daarbij gebruik makend van procedures, afspraken en gewoontes. Teams bestaan gedurende een langere periode en er is vaak geen vastgesteld eindpunt. Voorbeelden: een directieteam, een woongroepteam.

Voor de studie van arbeidsgroepen zijn drie systeemniveaus relevant: (1) het niveau wan de individuele leden, (2) van de groepsinteracties, en (3) van de organisatorische context warbinnen de groep functionect. Voor de studic van de dynamiek van werkgroepen stellen Arrow en McGrath een theoretische model voor (figuur 3.1). De zeven impactgebieden in dit model weerspiegelen de dric systeemniveaus waarbij de gebieden 1,4 en 7 uitsluitend met één niveau samenhangen ('welzijn' van respectievelijk de organisatie, groep en individu) en de overige interactiegebieden zijn tussen de aanpalende niveaus.

Volgens Arrow en McGrath reduceert continuiteit in teamsamenstelling de variabiliteit in het gedrag wan teamleden, en verhoogt het de voorspelbaarheid. Continuilteit leidt tot routine in de interactiepatronen van een team. Veranderingen in de teamsamenstelling verhogen de variabiliteit in gedrag en reduceren de voor- 
spelbaratheid. Veranderingen leiden tot verstoringen in interactiepatronen. Of dit een woordee of een nadeel is hangt af wan de aard van de opdracht en de taken. Wanneer taken veranderen of creativiteit wordt verwacht, zijn veranderingen in teamsamenstelling gunstig voor de effectiviteit. Wanneer bij een constant blijvende opdracht veel energie moet worden besteed aan inpassing en aanpassing aan nieuwe groepsleden, is dit ongunstig voor de effectiviteit.

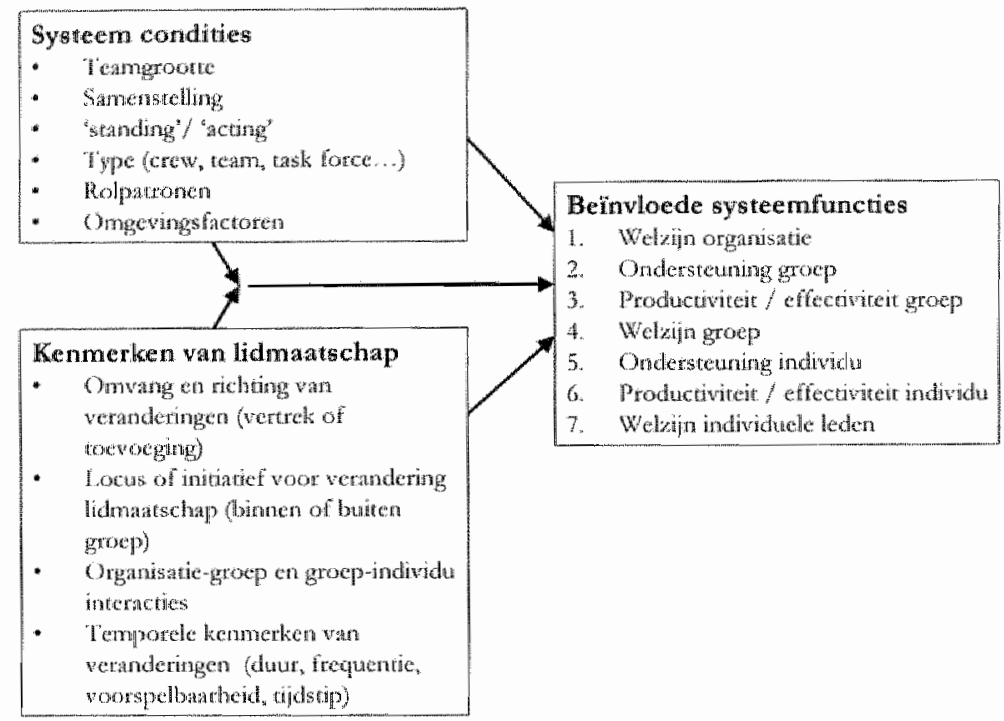

Fogun 3.1 Theoretisch model dynamiek groepssamenstelling (Arrow \& McGrath, 1995)

Zij formuleten verder een aantal stellingen waarvan, in de context van de doelstelling van onze studie, de volgende selectie relevant is om mede richting te geven aan het empirisch onderzoek.

- Bij de studie van dynamiek van groepssamenstelling moet onderscheid worden gemaakt tussen continuïteit en veranderingen in teamwisselingen.

- De impact van teamwisselingen hangt af van (de kenmerken van) de organisatieomgeving.

- De impact van teamwisselingen hangt af van het type groep (crew, task force, team).

- Continuiteit in groepssamenstelling bevordert het team-karakter. Hoe groter het ream-karakter van en groep hoe groter de impact van veranderingen in samensteling.

- De impact van teamwisselingen hangt af van de plaats van initiatief voor de verandering (binnen of buiten het team).

- Omvang en richting van veranderingen in groepssamenstelling (toevoegen van teamleden of verminderen van teamleden) leiden tot verschillend effect op de groep (bijvoorbeeld: op de effectiviteit). 
- De impact van teamwisselingen op de groep (biproorbeeld: effectiviteit) hangt af van hun temporele structuru (duur, frequentie, voorspelbarheid, tijdstip).

In de context wan meten van personeelswisselingen in woongroepteams pleit dit ervoor een onderscheid te maken tussen de stabiliteit van het team, de omvang van veranderingen in termen wan nieuwe teamleden, de duur van de continuiteit in termen van teamlidmaatschap, de locus van initiatief woor verandering en het moment van verandering, in relatie tor de ontwikkeling wan het team of van zijn taken.

\section{Experimenteel onderzoek}

Het aantal experimentele studies met het theoretisch model van Artow en McGrath is beperkt. In 1997 verschijnt een studie van Arrow waarin het moment van wisselingen in een 'task force' groep wordt bestudeerd en mede wordt gerelateerd aan technologie (communicatie tussen de leden via computer of face-to-face). Het experiment vond plaats met 81 studenten in 22 groepen ( 3 tot 4 leden) gedurende dertien weken. Daarbij ging het om cognitieve en creatieve taken (genereten van oplossingen in een fictieve consulting casus). Wisselingen in het team beïnvloedden de teameffectiviteit positief.

De La Hera en Rodriguez publiceren in 1999 de resultaten van een vergelikbare studie wartin 32 studenten gedurende acht weken in 8 groepen van telkens 4 leden werkten an een niet nader omschreven cognitieve en creatieve taak. Terwijl de studie antoont dat wisselingen in de samenstelling van de groepen met betere kwalitatieve en kwantitatieve resultaten gepaard gaan, vermelden de auteurs dat deze resultaten sterk taakspecifiek zijn.

Geconcludeerd kan worden dat er geen experimenteel onderzoek voorhanden is waarin het model van Arrow en McGrath in situaties wan dienstenteams, met geschoolde krachten in complexe taken, over langere periode wetd getoetst. Wel wijzen deze experimenten erop dat het effect van teamwisselingen op de effectiviteit niet noodzakeliik negatief hoeft te zijn. Hun model geeft wel een aantal relevante begrippen en relaties aan (tussen organisatieomgeving, kenmerken wan de teamwisselingen en uitkomsten in systeemfuncties). Hiemee zal bij de formulering van het theoretisch kader van deze studie rekening worden houclen.

\subsubsection{Verband tussen 'verloop' of 'personeelswisselingen' en 'kwaliteit van zorg'}

Empirische studies naar effecten van personeelswisselingen op het gedrag van bewonets of op zorgpatronen binnen woongroepen zijn schaars. In de literatuur wordt geen enkele studie aangetroffen die gebruik makkt van een experimenteel of quasi-experimenteel design om deze effecten in de praktijk te onderzoeken. Wel geven de volgende studies aanwijzingen over de relatie tussen personcelswisselingen en aspecten van kwaliteit van zorg en kwaliteit van bestaan van de 
bewoners van woongroepen in residentiele instellingen. Een causale relatie is dit echter nict.

Tizard's Brookland studie (1964) geeft kwalitatieve aanwijzingen dat de ontwikkeling wan kinderen in een kleinere woongroep met meer stabiele bezetting wan groepsleiders gunstiger verloopt. Het design laat niet toe dit effect met zekerheid toe te schrijven aan de grotere continuteit van groepsleiders, maar de auteur interpteteett deze relatie wel op grond van het karakteristieke verschil van dit kenmatk tussen het growp bome en het instituut.

Munro, Duncan en Seymour (1983) vonden geen verband tussen personeelswisselingen en frequentie en duur van toepassing van time-out. Nissen en Haveman (1997) vinden bij tien residentiele instellingen een hoger verloop in woongroepteams van bewoners met zelfverwondend gedrag, mar in drie instellingen is het verloop daar juist kleiner.

De Bontridder (1987) vond geen relatie tussen gedragsveranderingen van bewoners en de mate van continuteit in het team van gtoepsleiders dat bewoners begeleidde in een periode warin een omvangrijke vethuizing platsvond.

Cope, Grossnickle, Covington, Durham \& Zaharia (1987) stellen dat verloop juist een positieve functie kan hebben voor zover minder goed presterende groepsleiders wit het team verdwijnen. Ook kan cen te langdurige en intensieve betrokkenheid van groepsleiders binnen een zelfde woongroep leiden tot burnout en tor minder goede relaties tussen groepsleiding en bewoners (Caton, Grossnickle, Cope, Long \& Mitchell, 1988; Edwards en Mittenberg, 1991).

Op solide theoretische gronden kan worden aangenomen dat frequente personeelswisselingen hechtingsprocessen belemmeren. Hechting is niet alleen relevant in de eerste jaren van de menselijke ontwikkeling en beperkt zich niet tot de ouders van het jonge kind. Gehechtheidsrelaties zijn relevant op elke leeftujd. De reden daarvan is dat mensen in het streven naar bevrediging van behoeften gevoelig zijn voor personen in hun ongeving die daatbij een faciliterende rol (kunnen) spelen. Hechtingsgedrag is olk gedrng dat leidt tot het bevorderen of behouden van de nabijheid var cen ander persoon van wie men verwacht of ervaren heeft dat deze behulpzaam is bij het functioneten of bij het reduceren van stress en coping-problemen. De ervaring dat een hechtingsfiguur beschikbar en responsief is leidt tot een duurzaam veilig gevoel, in het bijzonder bij mensen die vemoeid, angstig of (chronisch) ziek zijn (Bowlby, 1988, p. 26-27). De beschikbaatheid van een ondersteunend persoon en de zekerheid dat deze op zorgvragen reageert, maakt de gehecht. heidsrelatie functioneel en bekrachtigt harr voortbestaan. De combinatie van complexiteit van individuele oproedingsarrangementen met de beperking in cognitieve vermogens van mensen met een (ernstige) verstandelije handicap, maakt dar in woongroepen wan residentiële voorzieningen sterk gekapitaliseerd (zal) moeten worden op de vermogens van de professionele opvoeders om een gehechtheidrelatie tot stand te brengen' (Vlaskamp, 1993, p.22). Deze auteur wijst erop dat bewoners overbelast kunnen raken door een steeds wisselend en niet op hun 
behoeften afgestemd aanbod van begeleiders. Dit kan leiden tot vemijdingsgedrag of isolement van de kant van bewoners. Vlaskamp lat ook zien dat personeelsverloop en wisseldiensten de context voor alle betrokkenen onduidelijk maken en het kennisgebrek bij groepsleiders doet toenemen. Dit leidt ertoe dat groepsleiders hun werk onbevredigend kunnen ervaren door het gebrek aan het tot stand kunnen brengen van zinvolle communicarie en voonitgang (p. 23). Eir zijn empirische aanwijzingen dat een lagere gehechtheidkwaliteit bij mensen met verstandelijke beperkingen in residentiële zotg samen gaat met het frequenter vórkomen van psychopathologie (Nan Dal, 2000). Onderzoek toont ook aan dat positieve gehechtheidrelaties tussen groepsleiders en kinderen in professionele zorgsituaties zeer wel mogelijk zijn en zelfs los staan van de gehechtheidskwaliteit met hun ouders; voorwaarde is dat groepsleiders hun aandacht niet over teveel kinderen moeten verdelen en er voldoende tijd is on tot interactie te komen (Goossens \& IJzendoorn, 1990).

Wetenschappelijke auteurs betwijfelen niet dat frequente personeelswisselingen negatieve gevolgen hebben voor de kwaliteit van zorg en uiteindelijk voor de kwaliteit wan bestaan van bewoners met ernstige en meervoudige beperkingen van residentiële voorzieningen. Dit komt door hun grote afhankelijkheid van groepsleiders die hun zorgvtagen juist moeten kunnen inschatten en er vervolgens adequaat op moeten reageren (Baumeister et al., 1987; Braddock et al, 1992; Van Gennep, 1978; Lakin, 1988; Vlaskamp, 1993). Velthausz (1987) wijst erop dat gezien her minder conventionele karakter wan de communicatie vatn mensen met ernstige verstandelijke beperkingen en de sterke persoonsgebondenheid van de communicatic, de communicatieve betekenis van gedragingen in veel gevallen slechts achterhaald kan worden in langdurige omgang. Omdat mensen met ernstige tot zeer ernstige verstandelijke beperkingen - met vaak nog bijkomende motorische en/of zintuig. lijke beperkingen - geen langdurig contact aankunnen, zouden zij het meest zijn gebaat met talrijke contacten met cen zelfde begeleider. Vlaskamp wijst op het belang van sensitiviteit en responsiviteit van groepsleiding on een goede inschatting te kunnen maken wan de (zorg)behoeften van mensen met een (crnstige) verstandelijke handicap en hierop adequaat te reageren (Vlaskamp, 1993). Van der Maat (1992) stelt vast dat de mate van overeenstemming tussen twee groepsleiders in het reageren op hetzelfde gedrag van mensen met een enstige verstandelijke handicap gemiddeld 52 procent bedragt. Omdat het vertrekpunt van professionele begeleiding ligt bij het goed begrijpen van ondersteuningsbehoeften van individucle cliënten, vormen personeelswisselingen in dit verband een belemmerende factor voor een consistent en adequat patroon wan sensitiviteit en responsiviteit van groepsleiding. 


\subsubsection{Correlaten wan verloop en personeelswisselingen}

\section{Studies op organisatie niveau}

De volgende studies gaan over verloop van groepsleiders. Omdat wij primair geïnteresseerd zijn in personeelswisselingen en niet in verloop, worden deze studies hier niet in detail besproken, maat wordt volstaan met een korte beschrijving. De significant gebleken correlaten worden gegroepeerd in tabel 3.1. Studies over verloop zijn om twee redenen van belang. Ten eerste is een deel van de omvang wan personeelswisselingen in een team te wijten aan verloop en daarom kunnen zij aanwijzingen geven over variabelen die mede relevant zijn voor de studie van personeelswisselingen. Ten tweede is de methodologie - mer name operationaliseringen van 'verloop'- van deze studies televant voor de studie van personeelswisselingen.

In een uitgebreid overzichtsartikel behandelen Baumeister en Zaharia (1987) studies over verloop en verzuim van groepsleiders in de Amerikaanse residentiele zorg voor mensen met verstandelijke beperkingen. Deze studie vertrekt van de stelling dat een stabiele personeelsbezetting een kritische voorwaarde is voor het leveren van kwalitatief goede zorg en dat verloop en verzuim in dit verband belemmerende factoren zijn. De auteurs concluderen dat er nauwelijks studies zijn met betrekking tot effecten van verloop op cliënten. Wel zijn er studies over correlaten en voorspellers van verloop. Uit hun overzicht kunnen veertien betekenisvolle variabelen worden afgeleid (zie tabel 3.1). Baumeister en Zaharias komen tot de conclusie dat verloop niet vanuit eenvoudige modellen kan worden verklaard en eerder als proces dan als uitkomst moet worden opgevat.

David Braddock en Dave Mitchell van de School of Public Health (University of Illinois te Chicagoy publiceerden in 1992 en 1994 de uitkomsten van een uitvoerige studie naar verloop van groepsleiders in Amerikaanse instellingen. Zij gebruikten een representatieve steekproef van 930 residentiële voorzieningen; het betrof zowel grotere residentiele instellingen (public institutions) als kleinschalige woonvoorzieningen in de samenleving (private and public communty residential facilities). Zij onderzochten de samenhang tussen verloop en respectievelijk elf intra-organisatorische en drie extra-organisatorische variabelen. De significante correlaten van verloop zijn opgenomen in tabel 3.1.

Een pad analyse van voorspellers van verloop bij groepsleiders in Amerikaanse gromp bomes leverde een model op waarin algemene arbeidssatisfactie de grootste bijdrage levert (Razza, 1993). De belangrijkste antecedenten van arbeidssatisfactie bleken: burnout, overeenkomst tussen persoonlijke watden van de medewerker en de kenmerken van hun functie, tevredenheid met leiding, en loopbaangeschiedenis. 
Sheryl Larson is de exponent wan een groep ondetzoekers wan de University of Minnesota te Minneapolis die tussen 1998 en 1999 verslag deden wan cen reeks studies nar werwing, behoud en verloop wan groepsleiders in de Amerikanse residentiele zorg. In tegenstelling tot Braddock en Mitchell die alleen aandacht besteden an structuutkenmetken van organisaties, besteedt Larson ook andacht an proceskenmerken en in bijzonder aan werkreacties van medewerkers. Ook de significante correlaten wit haar vetoopstudies zijn opgenomen in tabel 3.1 .

David Felce publiceerde samen met Lowe en Beswick in 1993 een artikel warin verloop in twee Engelse organisaties met Kleinschalige en geintegreerde woonvomen wordt beschreven. Zij vonden binnen elke organisatie aanzienlike verschillen tussen de woongroepteams. Hun adviezen voor het mamaement van woonvoorzieningen zijn niet gebaseerd op empirisch gevonden relaties maar op algemene aanwijzingen met betrekking tot training, constructieve feedback natr groepsleiding, en bevorderen wan arbeidssatisfactic. Daarbij vinden zij dat het beleid binnen een zorgorganisatie niet alleen gericht moet zijn op het beperken van verloop - dat zij als een moeilijk vermijdban aspect van professionele zorg beschouwen - mat* vooral op het bevorderen van voor de clièntenzorg relevante prestaties door groepsleiders.

In een recent onderzoek vatn Test, Flowers, Hewitt en Solow (2003) werden groepsleiders $(N=181)$, mensen met verstandelijke beperkingen zelf $(N=70)$ en managers $(\mathrm{N}=108$ ) van community services (waatonder residentiele diensten en thuiszorg) in North Carolina (USA) bevraagd door middel van focusgroepen en enquêtes. De auteurs concludeten dat een hoog verloop problemen veroorzakt voor zowel groepsleiders als diënten en gepaard gaat met lagere kwaliteit van zorg. Clienten rapporteren dat zij 'verdriet' hebben bij het vertrek van groepsleiders met wie zij een goede relatie hadden en dat zij voottdurend nieuwe vertrouwenstelaties moeten opbouwen. Sommigen geven aan zich schuldig te roelen naar aanleiding van vertek van groepsleiders. Daarmast vinden zij dat nieuwe grocpsleiders de begeleiding weer anders willen aanpakken, waatdoor een groot berocp wordt gedaan op het aanpassingsvermogen van monsen met verstandelike bepertaingen.

Als correlaten wan een hoog verloop vinden Test et al. in deze studie: (1) het lage anzien van het beroep van groepsleidet in de Amerikanse samenleving (onduidelike sociale roly, (2) het lage salarisniveau en (3) gebrekkige secundaire arbeidsvoorwaarden (antal betaalde vakantiodagen, dootbetaling baj ziekte, pensioenopbouw, werkgeversbijdrage in ziektekostenverzekering).

Alle hietboven genoemde onderzoeken zijn beschrijvende studies. Waar cortelaten van verloop worden onderzocht, gebeurt dat niet op basis van theorie. Braddock et al. en Latson et al verwijzen slechts zijdelings naar verlooptheorieèn of modellen; zi) ontlenen er wel variabelen aan woor hun survey onderzoeken maar toetsen geen bypothesen. Hun argument is daarbij dat de industriemodellen - watrop verlooptheoriën veelal zijn gebaseerd - in de praktijk van residentiélc zorg voor mensen 
met verstandelijke beperkingen slechts beperkt toepasbaar zijn (Braddock \& Mittchell, 1992).

Dit ligt anders met de studies van de Engelse onderzoekers Chris Hatton, Eric Emetson et al. (1993 en 2001). Zil beschrijuen niet alleen de telatie tussen enerzijds verloopintentie en anderzijds diverse werkteacties en werkkenmerken, mar stellen ook en empirisch model op om verloop, vertrekgeneigdheid en sollicitatiegedrag te voorspellen. De significante correlaten uit hun studies zijn eveneens opgenomen in tabel 3.1. De belangrijkste ditecte correlaten van vertrekgeneigdheid blijken in hun sudies: (1) arbeidssatisfactie, (2) werkstress, (3) jonge leeftijd, en (4) ervaren arbeidsomstandigheden.

\section{Studies op woongroep niveau}

Studies van personeelswisselingen op woongroepniveau weerspiegelen de combinatie van vetloop en wan wisselingen die om andere redenen optreden in het team. Dit geef ecn reëler beeld van de discontinuiteit in het begeleidingsteam waarmee bewoners daadwerkelijk geconfronteerd worden.

Het eerste empinische onderzoek waarin een relatie tussen gedtag wan bewoners en stabiliteit van groepsleiders werd gevonden is de Brookland-studie van Jack Tizand uit 1964. In een kleinschalige villa binnen de samenleving vond hij een grotere stabiliteit van groepsleiding, mincler probleemgedrag en meer kindgerichte patronen van zorg dan in een vergelijkbare gtoep verstandelijk gehandicapte kinderen die in het Fountain Hospital - een instituut - verbleven. In het instituut vonden beduidend meer personeelswisselingen plaats dan in de Brookland villa.

In een surveystudie van zestien woongroepen vonden King, Raynes en Tizard in 1971 een relatie tussen enerzijds meer bewonergetichte zorgpatronen en anderzijds en grotere continuiteit van groepsleiding.

In een studie binnen drie residentiële instellingen vond Buntinx (1994) dat de omvang van personeelswisselingen in de verschillende woongroepen van een zelfde instelling a anzicnlijk verschilt. Maar ook tussen instellingen verschillen de gemiddelden en varianties van personeelswisselingen in woongtoepen significant. Vootal de gemiddelde instroom van nieuwe groepsleiders binnen een team in de loop van een jarar, blijkt tussen instelingen significant te verschillen. De verklaring hiervoor ligt in verschillen in vervangingsbeleid: sommige instellingen putten vervangets voor tijelijke afwexigheid van groepsleiders (bijvoorbeeld in verband met ziekte, verlofperiode, ouderschapsverlof en dergelijke) uit een pool dicht bij de woongroep of groepering van woongroepen; andere putten uit een instellingsbrede pool of uitzendbureau. Deze bevindingen worden bevestigd in vervolgonderzoek (Buntinx, 2001) watin dratenboven een positieve correlatie werd gevonden tussen de omvang van personeelswisselingen en respectievelijk (1) de gemiddelde zorgzwaarte van de woongroep, (2) de grootte van de woongroep en (3) de mate van organisatorische clustering van woongroepen. Ook verschilden de gemiddelde personeelswisselingen weer significant tussen residentiële instellingen onderling evenals tussen sociowoningen en woongroepen 'op het terrein' (dit ten gunste van socio- 
woningen). In beide onderzoeken werd geen significant verband gevonden met de ratio groepsleiders: bewoners, percentage full-time versus deeltijd medewerkets in het team, percentage bewoners met ambulantiebeperkingen, percentage bewoners met gedragsproblemen en de gemiddelde leefuijd van de bewoners.

In een derde studie naar de aard van personeelswisselingen (Buntinx, 2002) werd vastgesteld dat het gebrek aan 'fit' tussen begeleiders en bewoners een belangrijke aanleiding vormt voor personeelswisselingen. 44 procent van alle personeelswisselingen bleek verband te houden met beëindiging van het dienstverband (verloop); 56 procent vindt plaats om andere redenen. Hieronder vallen: overplaatsing naar andere woongroepteams binnen de instelling $(35 \%)$; opleidingsgebonden vertrek $(14 \%)$; en einde tijdelijke plaatsing in het team $(6 \%)$. Overplaatsingen tussen woongroepteams van dezelfde instelling blijken in 60 procent van de gevallen op initiatief van de organisatie plaats te vinden. In deze studie werd een significant negatief verband vastgesteld tussen enerzijds personeelswisselingen en anderzijds de grootte van de woongroepen respectievelijk van het woongroepteam. Ook werd bevestigd dat personeelswisselingen tussen instellingen significant verschillen. Geen significant verband wordt gevonden met zorgzwaarte, sociowoning of woongroep 'op het terrein', noch met de ratio groepsleiders:bewoners.

Zijlstra, Vlaskamp en Buntinx (2001), Buntinx (2002) en Zijlstra (2003) rapporteren dat wisselingen zich niet ad random binnen een team voordoen, maar dat er ook medewerkers zijn die een aanzienlijke periode deel uirmaken van het team. Dezen zijn voor de continuiteit van zorg van grotere betekenis voor de bewoners. De factor 'tijd op woongroep' is daatmee naast de frequentie van wisselingen op zich, een belangrijke indicator van continuiteit wan zorg.

Tabel 3.1 geeft cen overzicht van significante relaties tussen verloop respectievelijk personet/swisselingen en diverse kenmerken die als variabelen in de besproken studies waren ingevoerd. De studies waarin expliciet de variabele personeelswisselingen werd gebruikt zijn gemarkeerd met *. Wanneer wordt gekeken naar significant met verloop samenhangende organisatiekenmerken die in meerdere studies worden gevonden (convergentie), dan blijken de volgende factoren van belang:

1. Instelling ('de ene instelling is de andere niet').

2. Sociowoning of woongroep op het instellingsterrein (dit kenmerk is alleen in Nederland onderzocht).

3. Grootte van woongroep(team) en van het cluster waarin de woongroep is opgenomen.

4. Gemiddeld niveau van verstandelijk functioneren of zorgzwarte van de woongroep.

5. Arbeidssatisfactie van groepsleiders.

6. Door teamleden ervaren participatie in besluitvorming, samenwerking en rolduidelijkheid. 
Tabel 3.1 Owerzicht vath in de wetenschappelijke literatum aangetroffen significante correlaten van werloop

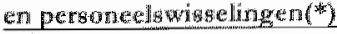

Kenmerken Situdie

\section{Kenmerken en werluteactes wan groepsleiders}

H. egrocht

2. lewijid

3. opleidingeniweat

4. algemene aberidsatistactic

5. commitment met otganisatic

6. toekomplannen / wertiekinentic

7. mate waatr det ban voldoet an de wewachingen

8. beeld dat de medewether van de baan heef voorafgand aan feiteliike start van werken in woongropep

9. erwatun wariate in het werk

10. rewedenheid over de eigen beroepsontwikkeling

1.. orewenlomst rusen eigen waten en nomen en dezth wan de organisticic

12. werkgebonden stress, werkdruk en burnout

13. lidmatselwap wark walbond

14. tewtenheid met leidinggevende

15. mate van ervaten democratische beslutwoming en samenwerking

16. crwaren soepetherid van werkgever met atbedsomstandigheden

17. ervaren rol(on)duädelikheid
Batumetster et al., 1987

Baumeister et al, 198 ?

Hatron et al, 2001

Baumeister et al., 1987

Batumeister et. al., $1993^{7}$

Braddock al., 1992

Hatton et al, 2001

Hatton et al., 1993

Razra., 1993

Felce et all, 1993*

Bawmestrer et al, 1987

Latson, Lakm et al., 1998

Hatton et all, 2001

Baumeister et all, 1987

Larson, Lakin et al. 1998

Latrson, Lakin et al. 1998

Biraddock et al., 1992

Latson, Lakin et al. 1998

Hatron et al, 1993

Larson, I akin et al., 1998

Larson, Jakin et al., 1998

Hatton et al, 1993

Larson, Lakin al al, 1998

Hatron et at. 2001

Razza, 1903

Braddock et al, 1992

Hateon et al., 2001

Razza $_{10} 1993$

Hatron et all. 1903

Larson, Hewrt et all, 1999

Hacton et al, 2001

Hatron er all., 2001

Harton er all., 2001

Hatron et all, 1993

Test et $a_{1}, 2003$

\section{Kenmerken van bewoners}

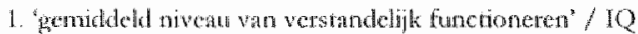

Baturicister al, 1987

Bradderck et al, 1902

2. zorgzwathe

3. heldeheid var zorgplan en antal cloelen in zorgplan

Buntirx, $1994 \%, 2001$ *

Latron, Lakin er a, 1998

Bameistet et al. 1987

\section{Organisatiekenmerken}

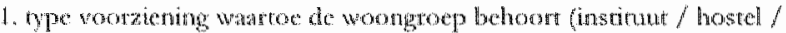
group honc)

Tizatd, 1964*

King et al, $1071^{*}$

Braddock et ail.., 1992

Buntinx, 2001\%

Baumeister er al 1987

Braddock et al, 1992 
Vervoly rabel 3.1

3. inscelling (binmen een zelfo type tesidentele insteling)

Bument $1904 * 2001 * 20022^{\text {in }}$

4. managementsill tan de organisate (centralisatic versus decentralisatic

Felce at. $190 \%$ van besilissingery)

5. groote wan de vookzening waatroe de woongroep behoort

Buturater et al, 198 ?

6. dagpijs van de voorziening

7. aratal jaren dar de woorziening operationeel is

Buaddock et al. 8902

Bradtock ef al. 1992

Braddock en 1902

5. antal uren geboden inwerwice scholing

L.8

9. kosten wan veranging wan groepsleiders

Brymadock at. 1992

Baumcister al 1987

Braddock or al 1992

10. salarisnwen

Butumeister er all., 1987

Braddock er al, 1992

Lason, Lakin er al., 1998

Haton et al., 1993

Tesent al, 2003

11. securdaire arbedsworwarden

Larson, Lakin er all, 1998

Tester al., 2003

\section{Woongtoepkenmerken}

1. grootte van de woongrocp

Batmeister a al., 1987

Brackock ot al, 1992

Buntinx, 2001*,2002*

2. ratio groepalciders bewoners

Braddock et al, 1992

3. rjol die de leidinggenende werkzam is in / woot de wongrop

liarson, Lakin et al, 1999

4. sociowoning wersus woongroep "op tertein"

5. groote wan het cluster watrin woongroep is opgenomen

Buntinx, 1994*, 2001*

Buatinx, 2001*

\section{Kenmerken van de intetactie groepsleiders-bewoners}

1. zorgparonen (omgang tussen groepsleiders en bewoners) Kitag et al., 1971*

Tizand, $196 \mathrm{Al}^{\text {th }}$

2. wertrouwen nssen groepsleiders en cliënt(systeem)

Test al., 2003

\section{Fxterne factoren}

1. regionale arbeidsmartst cn abeidsmobilireit

Braddock et a 1992

Latson, Lakin et al, 1928

Harton et all, 2001

Iestet al, 2003

2. sociale status van tha beroep

Bameister et all, 1989

Test et al, 2003

3. loonnumere in de reguo

Braddock at al 1992

Terit a a $200 \%$

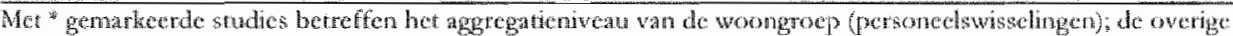

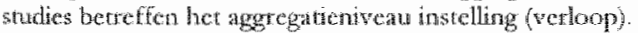

\subsubsection{Het meten van personeelswissellingen}

In de wetenschappelijke studie van continuiteit en stabiliteit van teams wordt onderscheid gemaakt tussen: (1) de omvang van het aantal wijzigende teamleden in functie van de teangrootte, (2) de frequentie waarmee wisselingen plaatsvinden (nieuwe toetreders), en (3) de duur van een periode van continu lidmaatschap (Arrow \& McGrath, 1995; De La Hera \& Rodriguez, 1999). 
T"abel 3.2 Maten woor personeeliswisselingen in wowngroepen, gebaiseerd op maten van "verloop" zoals: aragenofe in de literatuar.

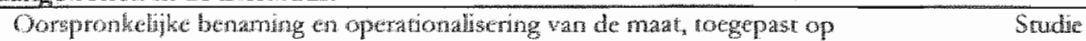

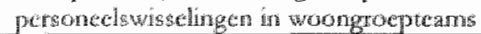

1. stability tate

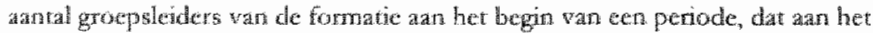
eind wa die periode nog th de formave zit, uitgedrukt als percentage wan het wax aratal groepseider in de sturfomatic

2. unstabiling wate

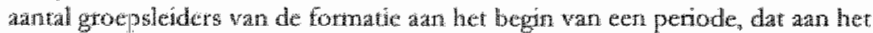
eind van die periodle petiode riet meer in de formane zir, outgedrukt als percentage wan het totaal antal groepleiders in de startomatic

3. antriton mate anthal groepsteiders dat in cen bepalde periode uit de formate van de woon-

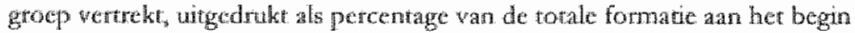

4. (gecn namar)

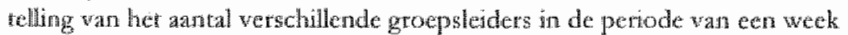
werteratan sign in een woongroep

5. (gech naam)

relling wan het antal nicuwe groepsleidets in een woongroep in cen bepalde perinde (in de studie: 26 weken)

6. accession rate antal nieuwe groepsleiders in een woongroep als percentage wan het gemideld

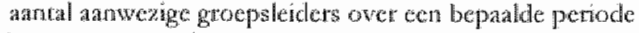

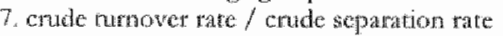
arantal grocessteiders dat in een bepalde periode een woongroep verast als

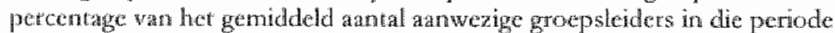

\section{8. wastige tate}

arantal netwe nedewerkes in cer bepalde periode dat weer wertrekt uit de woongroep als percentage van her total aantal nowwe medewerks dat in de wongropep in dic periode is ingetteden.

9. average tenurc

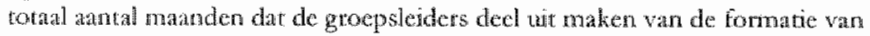
we wongroep, gedect door her antal gropsleiders in de formatie

10. percentage of leavers with vatious lengths of tenure aantal gecpsęders dat minder dan x manden in de woongroep werkte, als percentage wan het total anatal vertekkers wir de formatie van dese woongroep over cen jaar.

11. modian longth of service of leavers

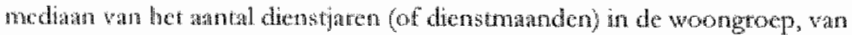
alle wit doz woongoep verteklende groepsleiders ower en bepalde periode

12. skill wwange ind

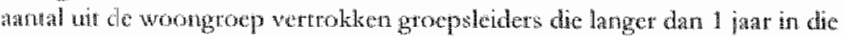
groep wetken, als percentage van de fomate anth her begin van de periode

13. dopatere indes

(1) depanthe index of well linowen faces beteft het percentage (ran thet ream) wistronkende groepsleiders die langer dan 6 manden decl utmakten van het swowngroptram; (2) 'departinte index of known faces': idem voor groepalchers nussen 25 dagen en 6 mataden; (3) 'doparture of new faces': idem

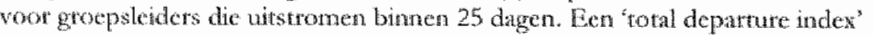
bestant uit de som van de drie genoemde indices.

14. allocations per year matull mew roegewezen groepsiciders per jatr pet woongroepteam

Baumeister et al., 198 ? Buntinx, 1994

Banmeister et al. 1987 Buntinx, 1994 .

Felce er anl., 1993

Braddockt er alc, 1992

King et al., 1971

King et al., 1971

Baumeister et al, 1987 Larson et al. 1998

Batumeister et al, 1987

Braddock ce al., 1992

Felce et al, 1993

Buntinx, 1994

Larson at al., 1909

Bradclock et al, 1992

Larson et al., 1998

J.aron er al., 1998

Baumeister er al., 1987

Braddock at al, 1992

Larson et al., 1998

Batmeister et al, 1987

Zuiflatra al al, 2001; Zijstser, 2003

Felce, 198? 
In praktijkgerichte verloopstudies op organisatieniveau binnen de zorg voor mensen met verstandelijke beperkingen wordt gebruk gemaakt van uiteenlopende maten en berekeningswijzen. Het meten van personeelswisselingen op teammirad wertoont in technische zin overeenkomst met het meten van verloop op instellingsniveau: vertrekmutaties van medewerkers (groepsleiders) worden in dit geval getelateerd aan de onvang van het woongroepteam in plaats van an het totale personeelsbestand van de organisatie. Daarmee is een nadere studie van in empirisch onderzoek gebruikte verloopmaten relevant voor het opstellen van maten van personeelswisselingen voor ons onderzoek. In tabel 3.2 staat het resultaat van een inventarisatie van gebruikte verloopmaten in de in paragraaf 3.2 .3 besproken studies. Bij de toelichting wordt de oorspronkelijke berekeningswijze - waar nodig - getransponeetd naar het meten van personeelswisselingen. De veertien verschillende maten kunnen herleid worden tot de drie volgende typen:

1. Type I: maten die over een bepaalde tijdspanne de verschillen tussen een aanvangsformatie en een eindformatie weergeven (het percentage vertrekkers of blijvers vormen een maat voor instabiliteit respectievelijk stabiliteit van de teamsamenstelling);

2. Type II: maten die het totaal antal vertrekmutaties of instroommutaties in een bepaalde tijdspanne weergeven (frequentie uit- of instromets waarmee fluctuaties in teamsamenstelling worden weergegeven);

3. Type III: maten die de gemiddelde duur van het teamlidmaatschap op een bepaald moment in de tijd aangeven (individueel: de tijd die een medewerker deel uitmaakt van het woongroepteam; op teamniveau: de gemiddelde lidmaatschaptijd van alle teamleden).

De meetperiode voor het berekenen van personeelswisselingen bedraagt standaard één jaar.

Bij de operationalisering van 'personeelswisselingen' in deze studie (hoofdstuk 6) zal van deze typen gebruik worden gemaakt. Ook zal rekening worden gehouden mer de aanbeveling van Braddock \& Mitchell (1992) om meerdere maten van PW te gebruiken. De verschillende typen verwijzen naat verschillende modaliteiten van personeelswisselingen: de omvang van de wisselingen (1), frequentie van de wisselingen (II) en gemiddelde duur van het teamlidmaatschap (III).

\subsubsection{Conclusie}

Uit de literatuur blijkt dat verloop als 'kwaliteit van zorg' probleem in de residentiële zorg voor mensen met verstandelijke beperkingen, een algemeen voorkomend probleem is. Verloop wordt in verband gebracht met uiteenlopende kwaliteitsproblemen in drie aspecten van het begeleidingsproces: (1) de interactic tussen groepsleiders en cliëntsysteem (bijvoorbeeld: een gebrek aan verttouwdheid en vertrouwen tussen groepsleiders en cliênten of hun familie; bejegeningproblemen; zorgpatronen), (2) de uitkomsten van begeleiding (bijvoorbeeld: door de zorgomgeving geinduceerde gedragsproblemen van cliënten) en (3) het funcrioneren van groepsleiders (bijvoorbeeld: werkkenmerken zoals arbeidssatisfactie; 
commitment met de organisatie). Personeelswisselingen blijken een complexer fenomeen dan verloop; vanuit cliëntenperspectief kan de omvang van personeelswisselingen veelvouden bedragen van het verloopcijfer vanuit organisatieperspectief. Voor onderzoek met betrekking tot kwaliteit van zorg in het algemeen en van (dis)continuitteit van zorg in het bijzonder, vertegenwoordigt de mat 'personeelswisselingen' daarom een meer relevante indicator dan verloop.

In empirische studies werd tot nu toe overwegend aandacht gegeven aan verloop als organisatie- en arbeidsmarktprobleem. Er zijn nauwelijks specifieke studies met betrekking tot personeelswisselingen; de enige studies zijn een drietal exploratieve studies in Nederlandse residentiële instellingen voor mensen met verstandelijke beperkingen. In de literatuur worden geen theoretische modellen voor de studie van personeelswisselingen aangetroffen. Uit verloopstudies kan wel informatie worden betrokken met betrekking tot relevante correlaten en de operationalisering van het begrip personeelswisselingen. Omdat méér dan de helft van de omvang van personeelswisselingen door intra-organisatorische factoren lijkt te worden geinduceerd, zijn vooral de intra-organisatorische correlaten wan verloop interessant. Samenvattend gaat het om de volgende factoren.

Een eerste groep heeft betrekking op organisatiekenmerken:

1. instelling als zodanig;

2. woongroep(team) als zodanig;

3. grootte van de woongroep;

4. sociowoning of woongroep op terrein;

5. omvang van het cluster waartoe de woongroep behoort;

6. zorgzwaarte van de bewoners.

Een tweede groep heeft betrekking op (de effectiviteit van) het teamfunctioneren:

1. arbeidssatisfactie van de teamleden;

2. een complex van werkreacties waaronder ervaren participatie in besluitvorming, samenwerking, overeenkomst tussen eigen waarden en die van de organisatie, commitment, werkstress en rolduidelijkheid.

Voor de operationalisering wan 'personeelswisselingen' werden drie typen maten angetroffen die telkens een ander aspect belichten: (I) uitstroom van teamleden uit een alanvangsformatie (stabiliteit); (II) frequentie van instroom van nieuwe teamleden (instroomfrequentie); cn (III) duur van het teamlidmaatschap (tijd op woongroep). Hiemee zal bij de operationalisering van ons onderzoek worden rekening gehouden. 


\section{Teameffectiviteit en kwaliteit}



In dit hoofdstuk worden in de paragraaf 4.1 de kenmerken verkend van residentiele instellingen als dienstenorganisaties; daarbij wordt de relevantie van het marketingconcept voor de studie van de effectiviteit van woongroepteams onderzocht en worden condities voor de effectiviteit van dienstenteams opgespoord. In samenhang daarmee wotdt in paragraaf 4.2 de studie van personeelswisselingen binnen het kader van kwaliteitszorg gesitueerd en worden personeelswisselingen als een 'continuiteit van zorg' probleem omschreven.

\subsection{De dienstenorganisatie en de effectiviteit van het teamfunctioneren}

\subsubsection{Dienstenorganisaties}

Vanuit het perspectief van organisatie en management moeten zorg en ondersteuning worden opgevat als diensten en niet als producten. Diensten zijn van oorsptong ontastbare en relatief snel vergankelijke activiteiten, warbij tijdens de interactieve consumptie directe behoeftesatisfactie centraal staat en geen materiële bezitsvorming wordt nagestreefd.' (De Vries, Van Helsdingen \& Kasper, 2001, p. 24),

Toegepast op de residentële zorg aan mensen met verstandelijke beperkingen, zijn de basiskenmerken van dienstverlening (De Vries, Van Helsdingen \& Kasper, 2001; Grönroos, 1990 ; Zeithaml, Parasuraman. \& Berry, 1990):

1. Ontastbaarheid: het gaat niet om een materieel product maar eerder om ervaringen, belevingen, gevoelens, vertrouwen, zekerheid of de "kwaliteit van het bestaan' van de cliënten. Dienstverlening bestat meer uit activiteiten en handelingen dan uit tastbare producten. Dit laat onverlet dat zorg en ondersteuning in belangrijke mate uit tastbare acties (verzorging en begeleiding) bestaan en dat tastbare zaken zoals gebouwen, uitrusting, materiaal maar ook documenten zoals cen 'zorgverleningovereenkomst' en 'individueel zorgplan' een rol spelen bij het leveretn en ervaten van een dienst.

2. Vergankelijkheid: de dienst ontstat op het moment dat hij wordt geteverd en in directe interactie met de cliënt; "productie" en 'consumptie' vinden gelijktijdig plaats. Er is geen opslag, uitstel, voorradvorming of overdracht naar een andere eigenaar mogelijk. Er is maar éen kans om het goed te doen en die doet zich voor binnen de "service encounter": de tijdspanne waarbinnen de cliënt direct interacteert met de dienstenorganisatie (Wetzels, 1998, p. 172).

3. Interactieve productie: de dienst komt tot stand binnen een wisselwerking tussen cliënt en dienstverlenet. De cliënt participeert tot op zelkete hoogte zelf in het voortbrengen van de dienst. Het verloop van de dienstverlening het proces - is daarmee net zo belangrijk. als de uitkomst. De client wordt daarom ook wel een 'prosumer' (samentrekking van producent en consument) genoemd. Hij vervult een eigen rol binnen het proces en moet die voor het welslagen van de dienstverlening ook goed vervullen (Bitner, 1995). Voor de gezondheidszorg heeft Van Wijmen dit kenmerk treffend uirgewerkt via het 
begrip "goed patientschap" (Van Wimen, 1996). Juist vanwege het interactieve karakter van begeleiding en het belang van wederzidse responsiwiteit in de dicnstwerlening aan mensen met verstandelijke beperkingen, kunnen beperkingen (in vardigheden en begripsvemogen) en (gedrags)stoumissen het prosumershap bemoeiliken. Het gebruik van speciale begeleidingstechnologie - zoals speciale opvoedingsprogramma's (Vlaskamp, 1993; Zijlstra, 2003) - kan daarbij aangewezen zijn.

4. Heterogeniteit: omdat de client mee deel uitmakt van het proces is dienstverlening hoogst individueel en daardoor heterogeen; standaardisatie is niet goed mogelik of niet wenselijk. Ook geliksoortige begeleiding wordt niet door alle clienten op gelijke wijze ervaren. De dienstretlening die een juist antwoord geeft op de vraag van de cliënt is contextgevoelig en kan van dag tot dag verschillen.

Alle activiteiten en begeleidingsdomeinen zoals genoemd in de inleiding (paragrat 1.3.1) passen binnen de definitie van dienstvetlening. Het oogmerk van begelleiding - het bevorderen van de kwaliteit van bestan van de client - bestaat in belangrijke mate uit diens persoonlijke ervaring van 'een goed bestaan'. Subjectieve belevingen watonder tevredenheid met aspecten van kwaliteit van bestaan maar ook individucle preferenties spelen daarbij een rol (Felce, 1997). In de residentiele begeleiding van mensen met verstandelijke beperkingen is er sprake van continue (7x24 uur) en langdurige, vaak levenslange dienstverlening. Dat betekent dat de contacten tussen dienstverleners en cliënten veelvuldig en langdurig zijn. Elk contact is een kritiek moment, een 'moment van de waarheid' voot de cliënt (Bitner, 1995). Het opbouwen en handhaven van langdurige goede relaties is de centralle opgave in de langdurige gezondheidszorg in het algemeen en van de residentiële dienstverlening aan mensen met verstandelijke beperkingen in het bijzonder. In deze sector met lange wachtlijsten en complexe toegangsprocedures (vaagverduideliking, indicatiestelling, zorgtoewijzing) is de overstap van de ene nat de andere dienstverlener daarenboven moeilijk. Tot de 'overstapkosten' behoren niet alleen het ondergan van de nodige bureaucratie maar ook het angaan van nieuwe relaties, opmieuw privé situaties moeten toelichten, nieuwe gewoonten aanleren; dit kost tijd en (emotionele) energie. Al dezze factoren vergroten de athankelijheid van de cliënt van zijn dienstvetleners.

\subsubsection{De vraaggerichte dienstenorganisatie}

Vanaf het begin van de jaren negentig is het cliëntenperspectief in de gehele Nederlandse gezondheidszorg sterk opgekomen. Begrippen als 'vraaggestuurde', "vraggerichte" en 'klantgerichte" zorg namen hiemee een hoge vlucht (Boon, 1997). In diverse nota's en artikelen is getracht deze begrippen te verhelderen en te operationaliseren. Op grond hiervan kan samenvattend wotden gezegd dat:

De begrippen 'vraagsturing' en 'vraggestuurde zorg' meestal betrekking hebben op het macroniveau van beleid en inrichting van het zorgstelsel. De 
begrippen verwijzen naar het binnen de structuur en financiering van de gezondheidszorg mogelijk maken dat beter ingespeeld wordt op war patiënten willen en belangrijk vinden (Coolen, Kramer, Schuring \& Sohl, 1999; Raad voor de Volksgezondheid en Zorg, 1998; Ministerie vanVWS, 2001a). Vraagsturing is daamee faciliterend voor vaaggerichte zorg.

'V taaggerichte zorg' verwijst naar de gezamenlijke inspanning van patiënten en hulpverleners die erin resulteert dat de patiënt de hulp krijgt die tegemoct komt aan zijn wensen en verwachtingen en tevens voldoet aan professionele standaarden (Raad voor de Volksgezondheid en Zorg, 1998). Het gaat om zorg die geboden wordt op momenten en plaatsen en op een wijze die aansluit bij wat de gebruiker wil en die ondersteuning biedt bij de invulling van zijn leven (Schuurman, 2001). Vraaggerichte zorg verwijst zowel naar de inrichting van het mesoniveau (organisatie en management binnen een concrete zorgorganisatie) als het microniveau van de interactie tussen een individuele cliënt en de professionele zorgverlener.

'Klantgerichte zorg' verwijst naar het cteèten van een optimale interne afstemming op de klant doorheen de gehele organisatie (Stavenuiter, 2002; Gibbels, 2000). Her is: 'De houding van dienstverleners ten opzichte van hun afnemers waarbij wordt uitgegaan van de wensen en behoeften van de afnemers, en een bereidheid om binnen de mogelijkheden en beperkingen van de organisatiedoelen, met volle inzet en conform afspraken aan die wensen en behoeften van afnemers te voldoen' (Besamusca-Janssen, 1997, p. 19). Klantgerichte zorg is een mesoniveau begrip. Klantgerichtheid wordt in organisatie en management beschouwd als een basale conditie voor het effectief functioneren van elke organisatie of onderneming omdat het doel altijd buiten de organisatie zelf ligt, bij het creëren van waarde als antwoord op individuele en/of maatschappelijke behoeften (Dnucker, 1983).

'Klantgerichtheid' is in de residentiële zorg voor mensen met verstandelijke beperkingen geen nieuw begrip. Reeds vanat het begin van de jaren zeventig stond het begrip 'bewonergerichtheid' ook in de Nederlandse residentiële zorg sterk op de voorgrond, mede als reactie op Goffman's kritische essay over 'total institutions' (Goffman, 1961). King, Raynes en Tizard (1971) operationaliseerden de door Goffrnan beschreven 'staff-inmate' interacties in een meetinstrument: de Resident Management Practices Scale. Deze schaal geeft aan in hoeverre activiteitenpatronen en zorgcondities binnen residentiële voorzieningen eerder cliëntgericht of organisatiegericht genoemd kunnen worden. Met deze schaal is international veel onderzoek gedaan om organisatorische detetminanten van kwaliteit van zorg (als bewonergerichte zorgpatronen) te achterhalen. Zo werd ondermeer de samenhang onderzocht tussen cliëntgerichtheid en de aard van de vootziening (instituut versus grotip bome), omvang van de voorziening, grootte van de woongroep, taakwerdelling binnen teams, mate van autonomie van groepsleiding, mate waarin leidinggevenden bettokken zijn in cliëntcontacten en arbeidssatisfactie van groepsleiding (Hatton, Emerson, Robertston, Henderson \& Cooper, 1995; King, Raynes \& Tizard, 1971; 
McCormick, Balla \& Zigler, 1975; Raynes, Pratt \& Roses, 1979). Ook in Nedetland is dit soort onderzoek gedaan (Damen, 1972; Geelen, 1995; Van Gennep, 1989; 1997; 1998) en het begrip heeft in kwaliteitsdiscussies een grote rol gespeeld (Buntinx, 1976, 1977; Hoeing, 1980). Het verschil met het huidige begrip 'klantgerichtheid' ligt in de verschuiving van het perspectief wan de professionele organisatie (die in het bewonergerichte' concept het impliciete referentiepunt was) naar het perspectief van de client (thans herkenbaar in begrippen als cliënttevredenheid, keuzevrijheid en keuzemogelijkheden). 'Bewonergerichte zorg' was daarmee een zaak van organisatie en professionals; aan de cliënten zelf of hun familie werd nog weinig gevraagd. Klantgerichte begeleiding in het nieuwe perspectief gaat uit van de centrale rol van het cliẻntsysteem en probeet antwoorden te geven op hun vtagen en behoeften.

Het gevolg van de nieuwe oriëntatie op klantgerichtheid is dat inhoudelijk meer aandacht wordt besteed aan vraggverduidelijking, individuele ondersteuningsplannen en persoonlijke begeleiding (Van den Berg-Willemsen, Braams, Pekelharing \& Wymenga, 2001; Van Broeckhoven, 1999; Van Gemert, 2002; Vlaskamp, 1993) en dat organisatorisch meer aandacht ontstond voor de relatie tussen dienstverlener en cliënten, voor cliënttevredenheid en voor de cliëntperceptie van kwaliteit (INK, 2001a,b; Vereniging Gehandicaptenzorg Nederland, 2000). Vraaggerichte dienstverlening komt neet op 'luisteren, verwachtingen creëten en verwachtingen waarmaken' (De Vries, Van Helsclingen \& Kasper, 2001, p. 21; zie ook Bitner, 1995) en is gericht op tevredenheid van de cliënt. Daarmee wordt vanuit organisatiepetspectief, de marketingbenadering relevant.

\subsubsection{Wie is de cliënt?}

In de enge zin is de petsoon met verstandelijke beperkingen die binnen een residentiële instelling verblijft de 'cliënt' van de organisatie. Om vijf redenen is die visic te beperkt.

Ten ecrste worden nagenoeg alle zorgverleningovereenkomsten in de residentiële zorg voor mensen met verstandelijke beperkingen gesloten met de ouders, familic of een wettelijke vertegenwoordiger van de cliënt. In formele zin zijn dezen daardoor mede cliënt van de organisatie.

Ten tweede maken cliënten deel uit van een sociaal netwerk. Binnen het ondersteuningsparadigma is dit sociaal netwerk van grote betekenis en kan het nooit worden vervangen door het professionele netwerk van een instelling. De cliënt is in de ondersteuningsvisie niet een individu dat als het ware opgesloten zit binnen een professioneel systeem (de oude zorgsituatie), maar een persoon die hulp nodig heeft bij het functioneren in zijn eigen sociaal netwetk en volgens zijn eigen keuzen (het nieuwe ondersteuningsparadigma). Ouders en familie herkennen zich nadrukkelijk in deze visie (Hoekstra, 2001; Van Leeuwen, 2004). Ook binnen het traditionele professionele systeem maakt de primaire cliënt deel uit van een clientsysteem (ouclers, verwanten, relaties) dat voor zijn functioneren en voor de 
begeleidingsactiviteiten wan de instelling van groot belang wondt gevonden (Vereniging Gehandicaptenzorg Nederland, 2000).

Ten derde weet iedereen die vertiouwd is met de praktijk van (residentiele) zorg voor mensen met verstandelike beperkingen, hoe belangrijk clënten zelf hun familie en kennissen vinden. Ook uit onderzoek in de residentiele zorg root mensen met verstandelijke beperkingen blijkt dat wanneet wordt gevtagad nart hun belangrijkste relatie, clienten zelf in grote meetderheid $(94 \%)$ hun familieleden aanwijzen en niet hun professionele zorgvetleners (Van Hove \& Boon, 1997, Van Hove \& $\operatorname{Van}$ Loon, 2003). Omgekeerd bljft de betrokkenheid van de familie bij de persoon met verstandelijke beperkingen in de residentiele zorg groot (Baker \& Blacher, 2002). Ook de betrokkenheid wan familie bij de zorgorganisatie is groot. Vooral bij organisatievetanderingen wordt dit pregnant zichtbaar. Zo stellen Hoogma, Van Grinsven en Wesseling: 'Als de ouders de koers van de organisatic niet actief ondersteunen, is elk transformatieproces gedoemd te mishlkken' (1998, (P. 82).

Een vierde reden voor het opnemen van familie en belangrijke derden binnen het cliëntconcept van residentiële instellingen is gelegen in de vele feitelijke activiteiten die een residentiële zorginstelling ontplooit naar ouders, familie en naaste betrokkenen van cliènten. Dit gebeurt zowel op individueel niveau (informatie over wel en wee, overleg met curatoren, bewindvoerders en mentoren rond belangrijke zaken) als op collectief niveau (overleg met de ouder- en familievenenging en cliëntentaad waarin ouders en familie valk zitting hebben). Ten vijfde is het gebruikelijk dat, wanneer cliënten vanwege de ernst van hun beperkingen niet in staat zijn zelfstandig te communiceren of persoonlijk mee te werken aan (wetenschappelijk) onderzoek en kwaliteitsprojecten, ouders, familieleden of belangrijke betrokkenen van buiten de instelling fungeren als belangenbehartiger of informant. Dit vindt zowel plaats binnen inhoudelijk georiënteerde kwaliteitsmethoden (Vreeke Janssen, Resnick \& Stolk, 1998; Maes, Baert, Moleman, Geeraert, Van den Bruel \& Samoy, 1997) als bij benchmarking (Vereniging Gehandicaptenzorg Nederland, 2002). De Zweedse onderzoekers Larsson \& Wilde Larsson (2001) vonden empirische argumenten voor de validiteit van deze wetkwijze binnen de kwaliteit wan zorg context: er blijkt een hoge mate van overeenkomst te bestaan tussen ervaringen van de kwaliteit van zotg van de betrokkene zelf en die van zijn ouders of familie respectievelijk wan groepsleiders.

Zonder afbreuk te doen an de eigenheid van een persoon met verstandeljike beperkingen, is de warneming wan de kwaliteit wan dienstverlening door familic en andere betrokkenen uit diens sociale netwerk, woor de zorgorganisatie een relcvante factor. Zorgkwaliteit zoals ervaten door familie en naast-betrokkenen van mensen met verstandelijke beperkingen bepaalt mede het 'consumentenvertrouwen' dat de organisatie geniet en is een factor van betekenis voot het managen van de kwaliteit van dienstverlening en voor de strategische beleids woming. Het achterhalen van de doot cliëntsystemen ervaren kwaliteit wan zorg en inzicht in de condities die deze ervaring beinvloeden past binnen marketingonderzoek. 


\subsubsection{Cliëntgerichtheid en marketing}

Met de verschuiving naar klantgerichte begeleiding wordt de vraag relevant onder welke condities een organisatie enin slaagt meer waarde te creëren voot hun clienten. Anders geformuleerd gaat het om de vraag onder welke condities cliènten een betere kwaliteit van dienstverlening ervaren. De wetenschappelijke discipline die zich bezig houdt met deze vraag is de anarketing. Theorieën en empirisch onderzoek uit de dienstenmarketing zijn daarmee een relevante kennisbron voor zowel onderzoek als praktijk van de organisatie van (residentiële) begeleiding en ondersteuning van mensen met verstandelijke beperkingen.

Marketing is een discipline die erop gericht is problemen van (potentiële) klanten te onderkennen, erop te anticiperen en deze op te lossen met het oog op het bereiken van een gunstig effect, zowell voor de klant als voor de eigen organisatie (Oyen \& De Schuyteneer, 2002). Kemobject van marketing is de transactie van 'waarden' zoals materiële wanten (geld en goederen), psychische waarden (gevoelens, vertrouwen, belevingen) en sociale waarden (plaats in de samenleving, status). Marketing heeft betrekking op het gedrag en het beleid van organisaties in relatie tot doelgroepen met als doel dit transactieproces optimaal te laten verlopen. In de gehandicaptensector ligt de nadruk niet op kortstondige of eenmalige transacties, maar op langdurige relatievorming. Aangaan en onderhouden van langdurige relaties is een bijzonder aspect van marketingstrategie waarbij drie zaken centraal staan: (1) de concrete interacties tussen dienstverleners en cliënten, (2) de door cliënten erwaren relationele kwaliteitsaspecten (hoe ervart men de dienstverleners), en (3) de mate waarin de organisatie (back-offtce) haat primaire teams in staat stelt de 'beloften' van de organisatie aan de cliënten waar te maken en daarmee dus effectief te zijn (Bitner, 1995; Grönroos, 1995).

Het marketingconcept is volstrekt valide binnen gezondheidszorgorganisaties. 'Met behulp van marketing kan er voor gezorgd worden dat het juiste aanbod (hulpverleningsacriviteiten) op een juiste wijze aan de juiste groep patiëtnten wordt aangeboden. Het is dan ook legitiem om marketing in de directe hulpverlening toe te passen. Hiermee kunnen de activiteiten worden afgestemd op de wensen en behoeften van de patiënten, hergeen tot gevolg kan hebben dat de patiënten een sociaal leefklimaat ervaren dat overeenkont met hun wensen' (Van Erp, 1989, p. 61).

De introductic van het marketingconcept in de zorg voor mensen met verstandelijke beperkingen vereist twee nadere beschouwingen.

'Ten eerste wordt aandacht besteed aan de opvatting dat marketing 'manipulatie', 'oppervlakkig' en 'onethisch' zou zijin en eerder bij commercie dan bij zorg zou thuishoren (Oyen \& De Schuyteneer, 2002). Volgens Oyen en De Schuyteneet vindt toepassing van marketingstrategieen en -methoden plaats binnen de visie en de wardenoriëntatie van de organisatie. Daarmee neemt deze verantwoordelijkheid voor een juiste toepassing van marketingkennis. Marketing betreft (1) het achterhalen van de vragen en verwachtingen van de cliënt, (2) het zowel op collectief als op individucel niveau van de cliënten formuleren van de mogelijkheden en 
pretenties van de organisatie, (3) het vorm geven aan de relatie tussen organisatie en cliënt, en (4) het bewaken van de mate waarin aan de wagen en verwachtingen van de cliënten wordt voldaan. Een positieve en duurzame relatie met de cliënt vereist een integere benadering; zoniet wordt de cliënt snel gedesillusioneerd en gaat vertrouwen verloren. Het marketingconcept is geschikt om diepgang en inhoud te geven aan de missie en visie van de otganisatie en de medewerkers daarbij te ondersteunen. Marketing is niet onethisch als zij ingezer wordt: om een juist beeld te creëren van wat cliënten en potentiële diënten kunnen verwachten en on de organisatie te helpen begeleidingsvragen wan clienten doelmatig te beantwoorden. In dit verband is het niet onethisch maar zelfs noodzakelijk om cliënten te wijzen op mogelijkheden die zij wellicht zelf niet kennen, maar ook op beperkingen die zij kunnen verwachten in de antwoorden op hun begeleidingswragen. Het gaat in klantgerichte begeleiding immers niet om een eenzijdig ' $u$ vraagt wij dranien' concept, maar om een relationeel en transactioneel proces tussen cliëntsysteem en otganisatie waarbij de professional een eigen verantwoordelijkheid heeft (Philipsen, 1997; Verbeek, 1999). Wettelijke kaders, professionele kwaliteitsstandaarden en de beroepsethiek van de betrokken professionals spelen in deze relatie een rol.

Ten tweede moet het begrip 'markt' nader omschreven worden. Dit begrip kent veje betekenissen zoals: samenstel van vraag en aanbod; een plaats waar transacties tussen vragers en aanbieders tot stand komen; de omvang vatn de behoefte aan een product of dienst; een tijdsperiode (seizoensmarkt); en een groep mensen van wie bepaalde behoeften bevredigd kunnen worden door de levering van goederen en diensten (Van Erp, 1989). In het algemeen worden de markten van een residentielle instelling voor mensen met verstandelijke beperkingen gevormd door de onderscheiden groepen die belang hebben bij en inwloed kunnen uitoefenen op de organisatie. In deze laatste betekenis bestaat de belangrijkste 'markt' natuurlijk uit mensen met verstandelijke beperkingen zelf en verder hun familie en andere naast betrokkenen. Maar dit is voor de dienstverlenende organisatie niet de enige matkt. Er is ook de markt van medewerkers (die ook behoeften en belangen hebben waaraan de organisatie tegemoet moet komen), en er zijn de markten van verwijzers, leveranciers, verzekeraars, overheden, collega zorgorganisaties (concurrenten en partners), financiers, en diverse publieke en private organisaties (zoals bijvoorbeeld woningcorporaties en sociale werkplatsen). In deze studie over personeelswisselingen wordt uitsluitend gekeken naat de 'markt' van cliënten.

Daannaast is het nodig het eigen karakter van de hier bedoelde 'marke' te omschrijven. Het gaat immers niet om een vrije commerciële markt waat de individuele vrager persoonlijk en autonoom kiest, bepaalt en betaalt. In de zorg voor mensen met verstandelijke beperkingen is er sprake van een zorgverleningsmarkt (relatie tussen cliënten en zotgaanbieders), een verzekeringsmarkt (telatie tussen cliënten en zorgkantoor en verzekeringen) en een inkoop of bekostigingsmarkt (relatie tussen zorgkantoren en zorgaanbieders). Op elk van deze matkten wil de overheid ook nog eens invloed behouden en regulerend optreden 
on voorturend stigende overheidsutgawen in de gezondheidszorg onder controle te houden (Delnoij, Asbroek, Arah, Custers \& Klazinga, 2002, Lapré \& Van Montfort, 1999; Nationale Raad voor de Volksgezondheid, 1993). Mensen met verstandelike beperkingen bewinden zich dus wiet in de positie van 'klanten' in een vilje markt. De te kiezen diensten zijn mede afhankelijk van de regels van vraagverduidelijking, indicatiestelling en zorgtoewijzing; en de cliënt betaalt niet persoonlik de dienstverlener, maar deze heeft contracten met zorgkantoren. Om vragggestuurde zorg dan toch te laten werken is nodig dat de beslissingsmacht van de cliënt ten overstaan van de andete spelers - zijn conntervaling pouner - wordt vergroot Ministerie van Volksgezondheid, Welzijn en Sport, 2001b; Stavenuiter, 2002). Dit laatste is een concrete uitwerking van het sinds de jaren negentig algemeen anvaard beleidsuitgangspunt van 'emancipatie' van mensen met een handicap. De afgelopen jaren is dit gebeutd (1) doot versterking van zijn rechtspositie (bijvoorbeeld doot de Wet Geneeskundige Behandelingsovereenkomst; Wet Klachtrecht Cliënten Zorgsector; Kwaliteitswet Zorginstellingen; Wet Medezeggenschap Cliënten Zorginstellingen; Wet Bijzondene Opnemingen Psychiatrische Ziekenhuizen), (2) door betere toegang tot informate (over aandoeningen, inzagerecht in dossiers, websites), (3) door beschikbatheid van onafhankelike indicatiestelling, advies en begeleiding (zorgconsulentschap), (4) door vergroting van de inkoopmacht (Persoonsgebonden en Persoonsvolgend Budget), en (5) door vergroting van zijn onderhandelingsmacht en ruimte voot belangenbehartiging.

De effecten van al deze nog tamelijk recente matregelen en ontwikkelingen zijn nog niet helder. In ieder geval kan, ook met in achtneming van bovenstaande, niet worden gesproken van een echte markt, mar eerder van een quasi-markt met nog vele onvolkomenheden. Daarmee moet bij de toepassing van marketingtlueoricen rekening worden gehouden, bijvoorbeeld door zorgvuldig de positie van de client te beschrijuen on voonal die factoren te identificeren die de 'vrijheidsgraden' van de clënt (bijvoorbeeld bij het overstappen nat een andere aanbieder) beperken.

Ondanks deze beperkingen zijn er tekenen die wijen op de groeiende relevantie van het marktconcept in de zotg voot mensen met verstandelije beperkingen. We noemen er drie. Ten eerste worden, worden instellingen met de introductie van het Persoonsgebonden Budget en Persoonsvolgend Budget in toenemende mate niet meer rechtsreeks gefinancierd, maat moeten $2 \mathrm{ij}$ hun inkomsten genereren door werving en behoud van cliënten die immers het budget met zich meebrengen.

Ten tweede is de modemisering van de AWBZ gebaseerd op functiegerichte dicnstenpakketten die aan diverse categotieèn wan cliënten (ouderen, chronisch zieken, gehandicapten) kunnen worden aangeboden (College voor Zorgverzekeringen, 2003; Coolen, 2003). Verschillende tradirionele ABWZ-aanbieders (Verpleging en rerzorging, GGZ en ook de Gehandicaptenzorg) kunnen daarmee hun doelgroepen uirbreiden en nieuwe dienst-markt combinaties creëren. Deze ontwikkeling vereist bij uitstek een viste op strategische dienstverlening en daarmee worden marketingtheorie en matketingmethoden voor zorginstellingen steeds relevanter (Meijer, 1990 ). 
Ten derde vinden de laatste tien jaren op grote schaal fusies en alliantievorming plaats tussen zorginstellingen onderling maar ook tussen zorginstellingen en andersoortige organisaties (bijwoorbeld: woningcorporaties). Dit laatsre gebeurt soms mede als gevolg van deconcentratie en vermaatschappelijking van de zorg waarbij het onvoordelig of onmogelijk wordt om alle diensten te blijyen leveren aan zeer kleine groepen of individuen die sterk verspreid in de regio wonen. Deze ontwikkelingen leiden ertoe dat vragen als 'wie zijn onze (potentiele) cliënten?", 'wie zijn onze concurtenten?", 'wat zijn onze (kern)diensten?', 'wie zijn alliantieparmets?" steeds relevanter worden. Meer dan voorheen zal een zorgorganisatie aandacht moeten besteden aan goede beeldvorming over de vagen van individuele cliènten en specifieke cliëntengroepen. De organisatie dient zich ervan te vergewissen dat de dienstverleningstelatie goed functioneert en zal daartoe een kwaliteitsbeleid moeten voeren. In de moderne zorgorganisatie zijn strategie, marketing en kwaliteit daarmee onlosmakelijk met elkaar verbonden (Musch, Wolterink en Van den Broek, 1994; figuur 4.1).

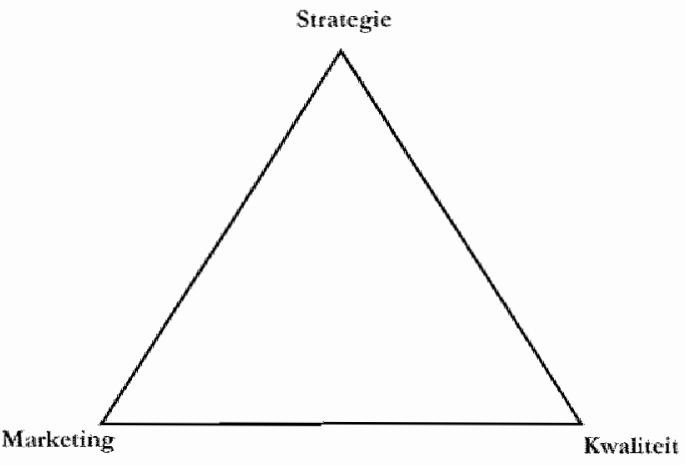

Figuur 4.1. Relatie tussen strategie, marketing en kwaliteit volgems Musch, Wolterink en Van den Broek $(1994, p, 2)$

Door de combinatie van de modernisering van de $A W B Z$, verdere cmancipatic en toenemende counteryailing power van mensen met functiebeperkingen zullen ook organisaties voor dienstverlening aan mensen met verstandelijke beperkingen meer aandacht aan stratcgisch beleid vanuit cliëntenperspectief moeten besteden. Zij krijgen immers te maken met nieuwe aanbieders, nieuwe cliëntengroepen, onderhandelingskracht van zorgkantoren, de mogelijkheid van substitutie van diensten (bijvoorbeeld: thuiszorg kan ook ondersteund wonen begeleiden) en met concurrentie (Porter, 1996).

Op grond van bovenstaande wordt geconcludeerd dat door het fundamenteel relationele karakter van de dienstverlening, door het centraal stellen wan de vragen van de client(systemen), en door het geleidelijk aan toenemen van de beslissingsmacht en de keuzemogelijkheden van cliënt(systemen) het marketingconcept voor (residentiële) instellingen voor mensen met verstandelijke beperkingen steeds relevanter wordt. Theorieën en onderzoek op het terrein van marketing kunnen een 
positieve bijdrage leveren aan de organisatic en het management van zorgorganisaties. De marketingbenadering is rechtsreeks verbonden met het kwaliteitsbeleid van cen zorgorganisate; daarom zal in paragraaf 4.2 dieper ingaan worden op kwaliteirsorg binnen residentiele instellingen. Eerst wordt echter nog het concept "clienttevedenhed" onderzocht en wordt gekeken naar wat marketingonderzoek leert over de relatie russen clënttevredenheid en teameffectiviteit.

\subsubsection{Cliëntevredenheid en kwaliteit}

Vanuit clëntenperspectef kan de perceptie van kwaliteit worden beschouwd als het resultaat van een afwegingsproces waarin de client de ervaren kwaliteit van dienstverlening vergelikt met de verwachte kwaliteit van dienstverlening (Grönroos, 1990; De Vries, Van Helsdingen \& Kasper, 2001). De afweging tussen verwachte en ervaren kwalliteit wordt telkens gemaakt voor vijf verschillende dimenies yan diensturlenng; tastbare zaken, betrouwbarheid, responsiviteit, zorgzaamheid en inleven in de klant (De Vries, Van Helsdingen \& Kasper, 2001). Deze dimensies liggen aan de basis van het SERVQUAJ meetinstrument voor waargenomen kwaliteit van dienstvenlening (Zeithaml, Parasuraman. \& Berry, 1990). Figuur 4.2 toont de componenten van dit model met de factoren die de ervaren en verwachte kwaliteit beinvloeden.

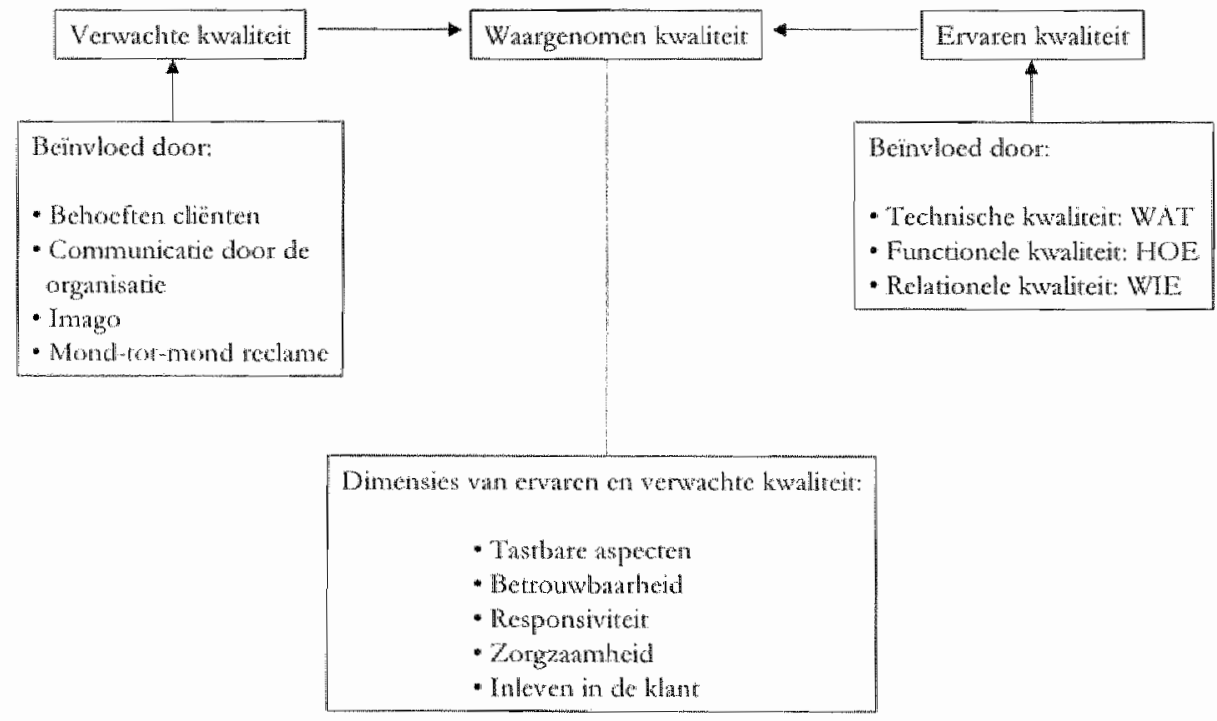

Figuur 4.2 Model van 'Waargenomen kwaliteit van dienstverlening', gebaseerd op Grönroos, 1990 (p.41), De Vries, Van Helsdingen en Kasper, 2001 (p.161) en Zeitham, Parasuraman \& Berty, 1990

De whyabte kwalitez" van de dienst worde beinwloed door de client (en zajn systeem) maar ook door referentiegroepen (andere cliënten van dezelfde en cliënten van andere organisaties) en door de organisatie zelf. Het gat daarbij om vier groepen factoren: 
- De behoeften en de zorgvragen wan de betrokken cliënt en clientsysteem.

- De verwachtingen die de organisatie zelf schept in haat communicatie met de cliënt, bijwoorbeeld wia gesprekken, zorgplanbesprekingen, brochures, magazines of internetsite.

- Het imago dat de organisatie heeft bij cliënt en cliëntsysteem, bijvoorbeeld op grond van ervaringen in het verleden.

- Informatie via mond-tot-mond communicatie tussen cliënten van dezelfde organisatie, bijvoorbeeld over ervaringen van anderen.

De enaren knaliteit van de dienst wordt beinvloed door drie groepen factoren:

- De 'technische kwaliteit' die betrekking heeft op de inhoud (het WAT) van de dienst. In de tesidentiële zorg voor mensen met verstandelijke beperkingen gaat het bijwoorbeeld om wonen, dagbesteding, vrije tijd, behandeling, zorg voor gezondheid en veiligheid, en ondersteuning van contacten. In ruime zin gaat het om alle gebieden waarop de ondersteuning betrekking heeft. In enge zin gaat het over specifieke afspraken die in het individuele zorgplan zijn gemaakt.

- De "functionele kwaliteit" die betrekking heeft op de wijze waarop de dienst wotdt geleverd (het HOE). Het gaat daarbij over aspecten als bejegening, geschiktheid en onderhoud van gebouwen waarin de zorg plaats vindt, functionaliteit wan vervoer, de groep waarin men de dienst ontwangt (medebewoners, drukte, gezelligheid) en het proces waarlangs de dienst tot stand kont.

- De 'relationele kwaliteit' die betrekking heefr op WIE de dienst levert. Dit aspect maakt geen deel uit van het oorspronkelijke model van Grönroos (1990); het valt daarin onder de 'functionele kwaliteit'. De Vries, Van Helsindingen en $\mathbb{K}$ asper onderscheiden dit wel apart als de relatie tussen de cliënt (cliëntsysteem) en de persoon of personen die de dienst leveren. Het gaat om de ervaring van professionaliteit, degelijkheid, gemak van communicatie, toegankelijkheid van de medewerker en om diens reputatie.

Het ligt voor de hand dat in een klantgerichte dienstenorganisatie, het oordeel van de cliënt over de te leveren en de geleverde diensten een belangrijke rol toebedeeld krijgt in het kwaliteitsmanagement van de organisatie. Zowel het INK-model als het MKG-model hecht belang aan tevredenheidsmetingen van cliënten voor de kwaliteitsbeoordeling van de uitkomsten van het zorgptoces. Maar de begrippen 'kwaliteit' en 'klanttevredenheid' vallen niet noodzakelijk samen. Er zijn vootbeelden genoeg denkbaar van situaties warin de client ontevreden is over de geleverde zorg terwijl die naar professionele en formele standaarden toch adequart is geleverd. Het omgekeerde is ook mogelijk. Gebruik van cliëntsatisfactie in kwaliteitsonderzoek verdient daarom een nadere beschouwing.

Volgens Casparie (1992) zal - wanneer we zijn conclusies transponeren naar de zorg voor mensen met verstandelijke beperkingen - een tevreden cliënt(systeem) eerder geneigd zijn mee te werken aan het zorgplan waardoor de effectiviteit ervan 
- en dus de kwaliteit van zorg - groter wordt. Daarnaast vormt cliënttevredenheid in het kader van het kwaliteitsbeleid een apart streefdoel van de zorg(organisatie). In het INK-en MKG-model is dit per definitie zo. Het is dan zaak eventuele discrepanties tussen kwaliteit zoals erwaren door professionals en cliënt(systeem) te verklleinen. Tot slot kan cliënttevredenheid een belangrijke informatiebron zijn voor de evaluatie van het beleid van de klantgerichte organisatie. Cliënttevredenheid kan daarmee worden beschouwd als een indicator van kwaliteit. In de context van het totale kwaliteitsbeleid levert de meting wan clienttevtedenheid een eigen bijdrage. In marketingtermen begint een zorgverleningproces met het begrijpen van de behoeften, de vragen en de verwachtingen van de cliënt. Deze zullen moeten worden omgezet in specificaties voor de te leveren kwaliteit van zorg. Onderzoek in de context van kwaliteitszorg kan gevoeglijk gebruik maken van metingen van cliënttevredenheid om daarmee relaties te verhelderen en de effectiviteit van zorgprocessen te onderzoeken. In het geval van deze studie naar personeelswisselingen zullen relaties tussen cliënttevredenheid (als uitkomstmat van zorgkwaliteit) en personeelswisselingen worden bestudeerd. Methodologische aspecten van deze keuze worden besproken in hoofdstuk 6 .

\subsubsection{Teameffectiviteit en cliënttevredenheid in marketingstudies}

In hun modellen the grle of failure, respectievelijk the gole of success in services vermelden Schlesinger en Heskett (1991) de volgende correlaten van hoge cliënttevredenheid in dienstenorganisaties:

Arbeidssatisfactie van medewerkers;

Laag verloop van medewerkers;

Hoge continuiteit in de relatie tussen cliënt en medewerkers.

Schneider, White en Paul (1998) concluderen uit een onderzoek in het bankwezen dat er een wederkerige relatie bestaat tussen de door cliënten ervaren kwaliteit van dienstverlening en het door het team van front-line medewerkers ervaren werkklimaat. Onder werkklimaat moet in dit geval worden verstaan: (1) de beleving van werkomstandigheden, (2) de beleving van (de effectiviteit van) werkwijzen om de gevraagde diensten te leveren en (3) de mate warin medewerkers positieve aandacht ontvangen van hun leidinggevenden voor het leveren van goede diensten. Omdat het een longitudinale studie met twee meetmomenten betrof, kon een wederkerig effect (uit een cross-lagged analysis) worden aangetoond, hetgeen betekent dat tevreden clienten op hun beurt bijdragen tot het door medewerkers ervaren werkklimaat. Hasenfeld stelt: 'the well-being of the worker is enhanced by investing in the well-being of the client and vice-versa. It is such mutual dependence that is most likely to foster mutual respect and trust.' (1992, p. 21). Heskett, Jones, Loveman, Sasser en Schlesinger (1994) bevestigen dat de ervaring van medewerkers om effectief bij te kunnen dragen tot de tevredenheid van de cliënt, een belangrijk aspect van hun arbeidssatisfactie is. 
In de gezondheidszorg wordt het verband tussen tevreden medewerkers en een hoge waardering van cliënten voor de dienstverlening eveneens onderkend; dartbij neemt men soms aan dat tevreden medewerkers 'automatisch' tot tevreden clienten leiden (Van Wijk \& Van Dijk, 2003). Op grond van het interactionele katakter van dienstverlening (paragraaf 4.1.1) en de eerder vermelde opvatting van Hasenfeld mag de wederkerigheid van dit verband echter niet over het hoofd worden gezien: tevteden cliënten dragen eveneens bij tot tevreden medewerkers. In een studie binnen Nederlandse residentiele instellingen voor mensen met verstandelijke beperkingen bleken uit een reeks wan zeventien onderzochte correlaten, de factoren 'tevredenheid met contacten met de familie van bewoners' en 'tevredenheid met de direct leidinggevende' het sterkst bij te dragen tot hun algemene arbeidssatisfactie en tot de blijfintentie van groepsleiders (Lemmens, 1993).

Arbeidssatisfactie, continuiteit van teamsamenstelling en continuiteit van relaties tussen teamleden en cliënten blijken condities te zijn voor de effectiviteit van het dienstenteam in temen van te realiseren cliëntsatisfactie. In de navolgende studie worden de effectiviteitscondities verder onderzocht.

Hartline en Ferrell (1996) bestudeerden drie belangrijke interfaces van hot dienstverleningsproces: de interface tussen respectievelijk leidinggevende en fromi-hine medewerkers, front-line medewerkers onderling (relaties binnen hun team), en frontlinte medewerkers en cliënten. Zij identificeren de volgende belangrijke antecedenten van cliënttevredenheid in het teamfunctioneren van frombline medewerkers (zie figur B6.1 in bijlage):

- Vertrouwen in eigen doelmatigheid van het team;

- Arbeidssatisfactie;

- Rolduidelijkheid van de medewerkers binnen het team (factoren mle confluct en ambiguity die positief bijdragen tot 'vertrouwen in eigen doelmatigheid' en 'arbeidssatisfactie');

Empowersment of autonomie (mate waatin leidinggevende ruimte geeft aan medewerkers om in te spelen op veranderende vragen en verwaclutingen van clienten) hetgeen bijdraagt tot 'vertrouwen in eigen cloclmatigheid" en 'rolduidelijkheid'.

Deze factoren kunnen worden beschouwd als effectiviteitaspecten van het teamfunctioneren. Het zijn aspecten die te maken hebben met de mate waatin cen team cliënttevredenheid kan bewerkstelligen.

Op grond van de besproken marketingstudies lijkt het relevant om deze antecedenten van cliënttevredenheid mee te nemen in empirisch onderzock naar het verband tussen personeelswisselingen en clientrevredenheid in residenciële instellingen voor mensen met verstandelijke beperkingen.

\subsection{De dienstenorganisatie en kwaliteitszorg}

Als werkdefinitie van 'kwaliteit van zorg' wordt in deze paragraaf Donabedian's omschrijving gehanteetd: "Kwwaliteit is de mate van overeenkomst tussen criteria 
van goede zorg (wenselijke zorg) en de praktijk van die zorg (feitelijke zorg)' (1982). Onder 'kwaliteitszorg' verstaan we: 'Het aspect van de totale managementfunctie dat het kwaliteitsbeleid (doelen, verantwoordelijkheden en middelen) vaststelt en implementeert'(Harteloh \& Casparie, 1998). In operationele zin betekent het: 'een cyclisch complex van activiteiten gericht op het verbeteren of handhaven van de kwaliteit van zorg' (Hollands, Hendriks \& Arièns, 2001, p.9). Kwaliteitszorg is continu, systematisch en integraal in die zin dat het de zorgorganisarie als geheel en alle medewerkers betreft (Verheggen, 1998). Het doel wan deze paragraaf is het voorwerp van deze studie - personeelswisselingen in relatie tot de door familie ervaren kwaliteit van begeleiding - te situeren binnen het kader van kwaliteitszorg. Daartoe worden achtereenvolgens besproken: de facetten van kwaliteit (4.2.1); de aandacht voor kwaliteitszorg in de tijd (4.2.2); indicatoren, modellen en systemen van kwaliteit (4.2.3); en her verband tussen continuiteit en kwaliteit (4.2.4).

\subsubsection{Facetten van kwaliteit}

'Kwaliteit' is cen moeilijk te hanteren begrip omdat het vele facetten heeft. Men kan 'kwaliteit' benaderen vanuit verschillende invalshoeken, volgens verschillende aspecten, vanuit verschillende partijen of belanghebbenden en op verschillende (organisatie)niveaus. Hierna worden de belangrijkste facetten van het begrip "kwaliteit' besproken om daarmee de benadering in deze studie naar personeelswisselingen te situeren.

\section{Invalshocken}

In navolging van Garvin (1984) onderscheiden De Vries, Van Helsdingen en $\mathbb{K}$ asper (2001, p. 159) wijf verschillende invalshoeken van kwaliteit.

1. De transcendente of filosofische benadering. Kwaliteit wordt beschouwd als 'het beste'; een toestand of eigenschap die zonder verdere verduidelijking universeel herkenbaar is. (And what is good, Phaedrus, and what is not good - Need we ask anyone to tell us these things?', Pirsig, 1974). Voor empirisch onderzoek biedt deze benadering weinig houvast.

2. De productgebaseerde benadering. Kwaliteit hangt af wan de mate waarin een bepaalde eigenschap in een product voorkomt. Deze benadering is vootal nuttig voor materiële producten waarbij verschillen in grondstoffen en productspecificaties concreet kunnen worden omschreven. Voor diensten is deze benadering minder geschikt omdat het gaat om prosumerschap waarin productic en consumptie samenvallen en vanwege het heterogene karakter van de uitkomst van dienstverlening.

3. De gebruikersgebaseerde benadering. Kwaliteit wordt bepaald door de gebruiker. Het gaat om de mate waarin het geheel van eigenschappen en kenmetken van een product of dienst beantwoordt aan de behoeften en verwachtingen van de gebruiker ('fitness for use'). Deze benadering vertegenwoordigt cen sterk subjectieve kijk op kwaliteit, maar is juist in zorg en dienstverlening van grote betekenis. 
4. De productiegebaseerde benadering. Kwaliteir betreft de mate warrin het proces van voortbrengen van een product of dienst beantwoordt wan standaarden. Hiertoe moeten in de zorg ook toepassing van dwingende normen wit wet- en regelgeving en van professionele standaarden (protocollen en goed vakmanschap) worden gerekend.

5. De waardegebonden benadering. Kwaliteit wordt beschouwd in relatie tot kosten en prijzen. Het gat om de verhouding tussen de door de cliënt ervaren voordelen van de dienst en de kosten die hij daarvoor (al dan niet in financiële termen) moet maken (Ferrell, Hartine \& Lucas, 2002, p. 101). Onder invloed van toenemend marktdenken krijgt deze latste benadering in de Nederlandse gezondheidszorg recent andacht met de introductie van begrippen als 'kwaliteitskosten' (Bouwmans, Van Ineveld, Custers, Bandel, Sol, Wagner, Wensing \& Klazinga, 2002), 'performance' en 'prestatieindicatoren' (Delnoij, Ten Asbroek, Arah, Custers \& Klazinga (2002).

Voor een dienstverlener is de gebruikersgebaseerde benadering van kwaliteit van bijzonder belang. Anclere benaderingen spelen wel een rol bij het tot stand komen van de dienst, maar de relatie tussen de activiteiten van de dienstverlenende organisatie met de waarneming van kwaliteit door de cliënt dient te allen tijde bewaakt te worden. Zo ontstaat niet het probleem dat een dienst wel aan professionele en bureauctatische normen (wetrelijke eisen en regelingen) voldoet, maar niet aan de verwachtingen van de cliënt. In de zorg voor mensen met verstandelijke beperkingen kunnen de verwachtingen van de cliënt echter niet altijd tot maatstaf wan de dienstverlening worden genomen. De reden kan tweevoudig zijn: communicatieproblemen of morele dilemma's. Bijvoorbeeld, vragen en verwachtingen van mensen met ernstige en meervoudige beperkingen kunnen soms moeilijk achterhaald worden. Niettemin zijn methoden beschikbaar om deze zo goed mogelijk te benaderen (Vlaskamp, 1993; Van den Berg-Willemsen, Braams, Pekelharing \& Wymenga, 2001). Bijvoorbeeld, niet aan alles wat iemand met een autistische spectrumstoornis, met cen psychiatrische stoornis of met gedragsproblemen vragt of wenselijk vindt kan worden voldalan, met name wannect het schadelijk of gevaarlijk is voor de persoon of zijn omgeving. De eigen verantwoordelijkheid wan de professional en de relatie van ce persoon met een belangrijke derde (belangenbehartiger, ouder, behandelaar) spelen in deze situatic een belangrijke rol om techt te doen aan de (achterliggende) behoeften van de persoon. De perceptie van de kwaliteit van de zorgverlening door familie of vertegenwoordiger is dan van bijzonder belang.

\section{2}

\section{Aspecten van zorg volgens Donabedian}

Omdat het verschijnsel 'zotg' zo veelomvattend is, is het nuttig on in de context van kwaliteitszorg een zekere vereenvoudiging en ordening aan te brengen. Donabedian's model (1980) is daarbij richtinggevend gebleken. Hij onderscheidt drie zorgaspecten: 
1. Structuutaspecten. Dit zijn woorwaardenscheppende aspecten zoals opleiding van de zotgrenleners, financiering, personeelsinzet, budget, organisatiestructuru; centraal staat de vraag": "wat heb ik nodig om het doel te bereiken?"

2. Procesaspecten. Het betreft het handelen van de zorgverleners en alle activiteiten die nodig zijn om zorg voort te brengen; centraal stat de vraag: "wat moet ik doen om het doel te bereiken?"

3. Resultaataspecten. De client is het primaire resultaataspect waarbij zijn gezondheid, welzin, tevredenheid belangrijke uitkomsten zijn. Maar ook kostenaspecten, doelmatigheid, arbeidstevredenheid van zorgretleners en matschappelijke effecten van de zorg vertegenwoordigen resultaatgebieden. Centrall staat de vraag: "wat wil ik precies bereiken?" Recent wordt onderscheid gemakt tussen 'output' en 'outcome' van zorg. Daarbij gaat het bij de output over (kenmerken van) de geleverde diensten als zodanig. Outcome betreft het effect van de geleverde diensten op de clienc (Delnoij, Ten Asbroek, Custers \& Klazinga, 2002).

Donabedian splitst met dit aspectenmodel de zorgorganisatie niet op in drie onderscheiden componenten, maar stelt drie aspecten of perspectieven voor warmee elk onderded van de zorgorganisatie kan worden benaderd (Hollands, Hendriks \& Arièns, 2001).

\section{Partijenperspectief}

De criteria voor de afweging van de kwaliteit van zorg zijn gebaseerd op waarden, normen en standaarden die door verschillende partijen van betrokkenen kunnen worden geformuleerd. Grol (1998) onderscheidt (weliswar niet limitatief) in de kwaliteitszorg wijf dergelijke pattijperspectieven.

1. Het professionele perspectief, dat steunt op 'goed' vakmanschap zoals dat binnen een discipline of groep beroepsbeoefenaren bestaat. Beroepsbeoefenaten stellen zelf standaarden op en claimen een zekere autonomie in de controle op en de verbetering van zorg. Binnen dere optiek zijn zaken als scholing, registratie en intervisie het probleem.

2. Het epidemiologisch perspecticf, dat steunt op wetenschappelijke en endenebased matstaven. De kern van het kwaliteitsprobleen is volgens deze benadering het ontbreken van overtuigende wetenschappelijke informatie over werkzamhet en doematigheid van werkwizen in de zorg en van daarop gebaseerde richrijnen.

3. Het polinck-economisch perspectief, dat tot utidtukking komt in wet-en regelgeving. Het kwaliteitsprobleem wotd gesteld in termen van tegelgeving, contracten, budgetten, indicatoren en inspectie wan buitenat.

4. Het managementperspectief, dat is gericht op de organisatorische context van de zorg: op doelmatige, efficiènte en klantgerichte processen en uitkomsten. Het kwaliteitsprobleem is het systeem van zorg- en dienstverlening. 
5. Het juridisch-ethisch perspectief dat uitgat van de emancipatie wan de cliënt, van zijn autonome en de participatie in beslissingen over zijn gezondheid en welzijn. Het probleem is participatie en autonomie.

Het marketingperspectief zou hieran beslist als zesde perspectief toegevoegd moeten worden. Voor cliënten en cliëntorganisaties staat een doelmatige interactie tussen enerzijds henzelf en anderzijds professionals en instellingen voorop. Voor hen tellen de mate waatin aan hun problemen en bun noden wordt tegemoet gekomen, respectvolle bejegening, duidelijk informatie, heldere afspraken en het nakomen van beloften. Voot individuele cliënten en cliëntenorganisaties is klantgerichtheid het kwaliteitsprobleem.

Elk van deze zes partijen kan als belanghebbende worden gezien. In het kwaliteitsdiscours kunnen zij opereren met verschillende bedoelingen zoals het verbeteren van de inhoudelijke zorg zelf, van de kwaliteir / prijs-verhouding, van de regelgeving, van het aanzien van het beroep of van samenwerking (Hollands, Hendriks en Arièns, 2001).

\section{$4 \quad$ Kwaliteitszorg op verschillende niveaus}

Kwaliteitsactiviteiten vinden plaats op verschillende niveaus. Voor elke actie van kwaliteitsverbetering of -borging dient men zich te realiseren op welk niveau deze plaats vindt en wat de invloed is op andere niveaus. Op macroniveau gaat het in de kwaliteitszorg over wet- en regelgeving, betoepsorganisaties, brancheorganisacies, verzekeraars, wetknemersorganisaties, cliëntenorganisaties, belangenverenigingen (zoals bijyoorbeeld Onderling Sterk) en de landelijke volksgezondheid. Op mesoniveau gaat het om het creëren van voorwaarden binnen de context van een zorgorganisatie. Het gaat daarbij om structuren en processen van de interne organisatie, maar ook om het creëren van relaties met de omgeving waardoor de organisatie beter in staat is aan de vragen van de cliënten tegemoet te komen en aantrekkelijk te zijn voor her werven van goede medewerkers. Het gaat enerzijds om het inteme faciliteren van de front-line om succesvolle interacties aan te gan met het clientsysteem. Het gaat anderzijds om het monitoren en bevorderen van matschappelijke effecten van de organisatie. Op microniveau gaat het om de interacties tussen clienten en de medewerkers die directe zorg en ondersteuning bieden. Daarbij zijn structuur en processen van de operating core (Mintzberg) van groot belang, evenals het monitoren wan de relaries met cliënten en wan de individuele uitkomsten van de zorg.

\section{$5 \quad$ Conclusie}

Binnen de besproken facetten van kwaliteir zijn de volgende kenmerken van toepassing op het doel van deze studie naar personeelswisselingen:

1. Invalshoek: in deze studie gaat het om gebruikersgebaseetde kwaliteit.

2. Aspecten: het teamfunctioneren en personeelswisselingen vomen beide proceskenmerken van kwaliteit; door familie ervaren kwaliteit van begeleiding is een resultaatkenmerk. 
3. Partijen: de cliëntsystemen vormen in deze studie de belangrijkste partij.

4. Niveau: de instelling als organisatie (mesoniveau) met bijzondere aandacht voor de interface van de organisatie met het cliëntsysteem (de woongroep).

\subsubsection{Aandacht voor kwaliteit in de loop van de tijd}

Aandacht woor kwaliteit is geen nieuw verschijnsel in residentiele instellingen woor mensen met verstandelijke beperkingen maar heeft in verschillende vormen vanaf het begin, in de tweede helft van de negentiende eeuw, een rol gespeeld. De criteria voor 'goede zorg' werden door initiatiefnemers en verantwoordelijken impliciet of expliciet verwoord in de missie van hun organisate. Vaak was deze geworteld in caritatieve en humanitaire beginselen, maar er werd ook gebruik gemaakt van beschikbare wetenschappelijke kennis om richting te geven aan de organisatie van de zorg. Historisch onderzoek toont aan dat de rol van de 'Inspectie van het krankzinnigenwezen" (Klijn, 1995, p. 40), de Onderwijsinspectie en de Inspectie van de kinderbescherming in de context van kwaliteitsbewaking en -bevordering niet mag worden onderschat. De studies van Klijn (1995) en Jak (1999) illustreren dat voor instellingen de rijksinspecties zowel de rol van bondgenoot als 'luis in de pels" vervulden. De rijksinspecties hielden niet alleen toezicht op de toepassing van wetgeving, maar bevorderden ook krachtig de professionalisering in de zorg, onder meer door hat pleidooien voor (verpleegkundige) scholing van medewerkers en toepassing van opvattingen uit de psychiatrie (zie ook paragraaf 2.1.1).

Vanaf het begin van de AWBZ-periode van de residentiele zorg in 1968 werd een grotere rol toebedeeld aan wetenschappelijk onderzoek, met name bij het identificeren van probleemgebieden en het formuleren van condities voor betere zorg binnen de instellingen (Van Ratingen, 1970). In de praktijk leidde dit tor discussies over de 'ideale grootte' van instellingen en woongroepen (voor een overzicht: zie Buntinx, 1976; 1977) maar ook tot aanzetten tot systematische benadering van het kwaliteitsprobleem. Een themanummer van het tijdschrift RUIT (december 1979, nummer 20) behandelt aspecten van kwaliteitsbewaking, de bedrijfskundige benadering van kwaliteit, een aanzet tot modelvorming, en cen beschrijving van het 'project Griffioen' dat aan de basis lag van de door Vlaskamp ontwikkelde opvoedingsprogramma's voor mensen met ernstige meervoudige beperkingen. Het nummer bevat ook twee attikelen over de werkgroep 'Kwaliteit en Doelmatigheid' van de Nederlandse Ziekenhuis Raad (NZR) die in 1973 speciaal voor de zwakzinnigenzorg in het leven was geroepen en die aan de basis ligt van de in 1983 gestarte interinstitutionele toctsing 'Kwaliteit en Doelmatigheid" ('Kwaldo'). In deze periode neemt het proefschrift van Daniel Seys uit 1987 (zie ook: Seys \& Duker, 1988) een bijzondere plats in vanwege het sterke betoog voor een exidence based benadering van kwaliteit en het centraal stellen van het management van effectieve clientbegeleider interacties. Dit laatste is een marketingsperspectief arant la lettre. Ook de constructie wan kwaliteitsmethoden en meetinstrumenten werd in deze periode ter hand genomen (Van Bergen, Hollands \& Nijhuis, 1980; Hollands, Van Bergen, Degenaar, Smits \& Van Veen, 1990). In 1.991 publiceert de Nationale Ziekenhuis- 
raad het document 'Herkenbare kwalitert' (gebaseerd op een teferentiekader van de Inspectie voor de Volksgezondheid) met een set criteria voor structuur- en proceskenmerken van residentiële instellingen. In de periode tussen 1970 en 1990 was kwaliteitszorg stetk inhoudelijk georiënteerd. Central staat het omschrijiven van (professionele) kenmerken van 'goede" zorg. Deze zijn gebaseerd op zorgvisies zoals "normalisatie" en/of op uitkomsten van onderzoek. Deze kenmerken worden dan omgezet in criteria of nastrevenswaardige doelen. Beroepsbeoefenaren en het primaire proces staan centraal.

De Leidschendamafspraken uit 1990 (volgend op een startconferentie in 1989) markeren het begin van een nieuwe periode van kwaliteitsbeleid en wormden mede door vijf follow-up conferenties in een periode wan tien jaar een constante impuls voor kwaliteitszorg en wetenschappelijk onderzoek met betrekking tot kwaliteitszorg. Het advies van de Raad voor Gezondheidszorgonderzoek (RGO) over kwaliteit wan zorg (1990) legde de basis voor het NWO-programma 'Kwaliteit van Zorg Onderzoek" (1992 - 2001) waarvan voor de zorg aan mensen met verstandelijke beperkingen met vier gesubsidieerde projecten een grote stimulans is uitgegaan (NWO, 2001). Het gunstige rendement van de KWAZO projecten in de zorg voor mensen met verstandelijke beperkingen droeg bij tot de start in 1997 van het programma 'Innovatie in de zorg voor mensen met verstandelijke beperkingen' van Zorgonderzoek Nederland (ZonMw).

De Leidschendamafspraken leidden tot een meer bedrijfskundige aanpak van kwaliteitszorg waarbij kwaliteitsmodellen en kwaliteitssystemen hun intrede doen. De bedrijfskundige aanpak kijkt niet alleen naar de kwaliteit van het (inhoudelijke) eindproduct maar vooral naar de wijze waarop zorg in alle onderdelen en fasen tot stand wordt gebracht. Het oogmerk is om binnen de gehele organisatie een constante en systematische oriëntatie op verbetering van de zorg tot stand te brengen met de cliënt als uitgangspunt (Berwick, 1989; Sluyter, 2000). De Kwaliteitswet Zorginstellingen uit 1996 verplicht zorginstellingen de organisatie zo in te richten dat deze redelijkerwijze moet leiden tot verantwoorde zorg, en de kwaliteit systematisch te bewaken, te beheersen en te verbeteren. Deze wet gaf een impuls aan het interne kwaliteitsbeleid wan instellingen en aan de toepassing van modellen en systemen.

\subsubsection{Indicatoren, modellen en systemen}

Met de besproken invalshoeken, aspecten, perspectieven en niveaus is nog allerminst duidelijk hoe kwaliteitszorg in de praktijk zou moeten werken. Daartoe is concretisering en operationalisering nodig. Concretisering betekent het kiezen van in de prakrijk herkenbare en relevante aandachtsgebieden. Op her niveau van de zorgorganisatie kunnen aandachtsgebieden bijvoorbeeld zijn: 'visie en strategisch beleid', 'personeel', de 'directe zorg- en dienstverlening', en 'waardering door cliënten'. Operationalisering betekent dat voor een bepald aandachtsgebied indicatoren worden geformuleerd. Een indicator is: 'een meetbaar element van de zorg- 
verlening welke functioneert als een mogelike aanwijzing voor de kwaliteit wan zorg." ( $\mathrm{RGO}, 1990$, p. 14). Of en op welke (drempel)warde een indicator dan 'echte' aanwizingen geeft hangt af van het gekozen criterium of de als optimal beschouwde situatie. De waarde van een indicator hangt darenboven af van zijn validiteit (relevantie woor de zorg; zijn relarie met uitkomsten van zorg), zijn meetbaarheid, betrouwbaarheid en sensitiviteit, en zijn toepasbaarheid in de bredere sector omdat daarmee benchmarking mogelijk wordt (Mintjes, Van den Broek \& Wille, 2000; Stating, Dutetloo, Ten Horn, 1993).

Meer dan 50 procent van de instellingen in de gehandicaptensector blijken de volgende indicatoren toe te passen (Sluijs, Van Beek, Mouthaan, De Neef \& Wagner, 2002):

Structuut-indicatoren: clièntenraden; personele bezetring.

Proces-indicatoren: (toetsing van) zorgplannen.

Resultaat-indicatoren: tevredenheid van cliënten en familie; tevtedenheid van medewetkers; zickteverzum en verloop van medewerkers als indicatoren van het kwaliteitsaspect 'continuiteit en stabiliteit'; ongewenste gebeurtenissen (klachten, bijna-ongelukken, incidentery). Over de relevantie van deze uitkomstindicatoren lijkt overigens consensus te bestaan in de gehele gezondheidszorg ondat deze in alle sectoren worden genoemd. Ook leggen instellingen een verband tussen de indicatoren 'tevredenheid van medewerkers" en 'tevredenheid van 'cliënten'.

Uit ditzelfde onderzoek blijkt dat de cure sector meer op indicatoren is georienteerd dan de care sector. Deze laatste rellativeert het gebruik van indicatoren met het argument dat nitet alles te kwantificeren valt en zaken zoals cultuur of (levensbeschouwelijke) visie ook van belang zijn als het gaat om de kwaliteit van zorg die de cliënt ontrangt.

Wanneer men geinteresseerd is in een enkel aandachtsgebied van de organisatie kunnen één of enkele met elkar samenhangende indicatoren volstaan. Maar kwaliteitszorg brengt meestal met zich mee dat naar meetdere aandachtsgebieden tegelijk moet wotden gekeken. De samenhang tussen aandachtsgebieden wordt daarmee relevant. Dit is het oogmerk van kwaliteitsmodellen. Een kwaliteitsmodel bevat cen vereenvoudigde representatie van de otganisatie met meestal de volgende kenmerken:

Een aantal activiteitengebieden van de organisatie met daatbij meer of minder uitgewerkte lijsten van indicatoren;

Een anduiding wan de relatie tussen deze activiteitengebieden;

Een dynamisch principe voor de toepassing van het model.

Het model dient als achtergrond voot conctete acties zoals evaluatie of diagnose van de actuele situatie, het plannen van verbeteracties, en het volgens de Deming cyclus (Plan-Do-Check-Act) starten van een continu proces van kwaliteitsvesbetering. Door de standaardisatie van concepten en processen bevorderen modellen de communicatie over kwaliteit tussen verschillende betrokkenen binnen en buiten de organisatie. Kwaliteitsmodellen kunnen gericht zijn op het manage- 
ment (zoals het INK-managementmodel en het Model Kwaliteitssysteem Gehandicaptenzorg), op het beheersen van processen (zoals de ISO 9000) of juist sterk op de inhoud van de zorg, zoals het orthopedagogisch referentiekader van Maes, Geeraert \& Van den Bruel (2000) en het Kompas van Van Gastel, Vermeer \& Rispens (2001). Tegenwoordig wordt in de (gehandicapten)zorg ook de Balanced Score Card (BSC) (Kaplan \& Norton, 1992) als kwaliteitsmodel gehanteercl. De BSC is een managementmodel dat sterk op kwaliteitswerbetering in relatie tot strategie is gericht maar ook het financiële aandachtsgebied omvat.

Modellen helpen om het abstracte begrip 'Kwaliteit' concreet en toepasbaar te maken, maar ze werken niet uit zichzelf. Modellen moeten deel uitmaken van een kwaliteitssysteem. Dit is: "een verzameling processen, procedures, werkinstructies en documenten in een logische samenhang en volgens een regelmatig weerkerende ordening' (Hollands, Hendriks \& Ariëns, 2001). Kwaliteitssystemen beschrijven de wijze waarop in een organisatie continu aan kwaliteitsverbetering wordt gedaan en dienen verankerd te zijn in de structurur van de organisatie. Daatbij moet de instelling haar beleid veranderen en bijsturen op basis van de uitkomsten van de zorg (Sluijs, Van Beek, Mouthaan, De Neef \& Wagner, 2002).

In Nederlandse voorzieningen voor mensen met verstandelijke beperkingen wordt in 10 procent van de gevallen gebruik gemaakt van het INK-managementmodel (figuur 4.3); 76 procent maakt gebruik wan het Model Kwaliteitssysteem Gehandicaptenzorg (figuur 4.4) (Bering \& Nabitz, 2000; Nivel, 2000).

Hoewel kwaliteitsindicatoren, -modellen en -systemen belangrijke elementen van kwaliteitszorg vormen, passen enkele kritische kanttekeningen.

Toepassing van een kwaliteitssysteem geeft op zich nog geen inzicht in de uitkomsten van de zorg en is op zichzelf ook geen garantie voor de kwaliteit op het niveau van de cliënt (Sluijs, Van Beek, Mouthaan, De Neef \& Wagner, 2002). Hoewel in de gehandicaptenzorg wordt gewerkt aan het definiëren van indicatoren, is nog niet duiclelijk hoe deze worden ingezet voor verbetering van de zorg. Ook blijkt reserve te bestaan voor de relatie tussen indicatoren (vooral als cijfers) en de kwaliteit van zorg. Zo is bijvoorbeeld het aantal klachten niet noodzakelijk cen indicatie voor de kwaliteit van zorg in het geheel van de instelling. Sterker nog, het blijkt 'dat de relatie tussen her hebben van een kwaliteitssysteem en her leveren van verantwoorde zorg (nog steeds) niet overtuigend is vastgesteld" (Inspectie voor de Gezondheidszorg, 2002, p.7). Door de verschuiving van de inhoudelijke benadering naar de bedrijfsmatige betnadering van kwaliteitszorg kost het continu monitoren van indicatoren veel tijd en geld. Daarenboven moet deze werkwijze geintegreerd worden binnen de gewone processen en de bedrijfsvoering van de instelling. Dit vergt een ingrijpend en langdurig veranderingsproces. Zolang dit niet optimaal is geimplementeerd kost een kwaliteitssysteem binnen een organisatie veel extra tijd en aandacht, maar levert het weinig verbeterresultaten op.

Op grond van een kritische beschouwing van dit verschijnsel en van de plaats van de professional in de instelling komt Casparie tot de conclusie: 'dat de belangrijkste 
bepalende factor van de kwaliteit van zorg de indwiduele professional is en niet het systcem, dat daar ook het aangrijpingspunt ligt om kwaliteit te verbeteren en dat het functioneren van de professional in het primaire proces, zowel individueel als als team het eerste object van externe beoordeling moet zijn. Het sturen op kwaliteit gaat via de professional.' (Casparie, 1998, p. 154). Deze conclusie is congruent met het feit dat het in langdurige zorg (voor mensen met verstandelijke beperkingen) eerder gaat om relaties en transacties van 'beloften' dan om tastbare zaken en eenvoudig meetbare uitkomsten (Bitner, 1995; Grönroos, 1995).

Ecn laatste kritische kanttekening betreft de validiteit van kwaliteitsmodellen. Noch INK noch het MKG model zijn voortgekomen uit wetenschappelijk onderzoek en er is geen literatuur waaruit blijkt dat zij als zodanig empirisch zijn getoetst en valide bevonden. $\mathrm{Zij}$ werden overwegend opgezet op basis van logische ordening en heuristische procedures, waarbij vervolgens consensusprocedures voor validatie werden gevolgd (Delphi-ronden en focusgroepen). Dit staat niet in de weg dat uitkomsten van onderzoek incrementeel een rol kunnen spelen bij de validering van praktrijkmodellen (Bij de Vaate, 1991); over het algemeen is echter weinig bekend over de empirische relaties tussen de aandachtsgebieden van de modellen en de condities waatonder deze leiden tot kwaliteitsverbetering. Het blijven algemene en heuristische modellen die voor de communicatie over kwaliteitszorg nuttig zijn maar het zijn geen procesmodellen aan de hand waarvan met redelije zekerheid een positief resultaat kan worden geboekt. Er kan dan ook geen eigen werkzaamheid aan worden toegedicht en alles hangt af van de specifieke toepassing door het management van een instelling (Wolves \& Van der Werf, 2000). Kwaliteitszorg is daarmee vooral een pragnatic science met als doel het verbeteren van zorg en dienstwerlening (Verheggen, 2003).

In het kader van kwaliteitszorg in residentiële instellingen, is her relevant om te kijken naar de samenhang tussen het proceskenmerk personeelswisselingen (als continuitteitsprobleem) en de resultaatgebieden 'waardering door cliënten' en 'waardering door medewerkers" (figuru 4.3). Personeelswisselingen doen zich namelijk voot in her gevoelige gebied wan het directe contact van individuele medewerkers met cliënten.

In INK-termen passen de aandachtsgebieden vatu deze studie binnen (1) de procesaspecten van organisatie (continuiteit respectievelijk personeelswisselingen) en de resultaatgebieden (2) waardering door medewerkers als onderdeel van het teanfunctioneren en (3) wardering door cliënten.

Binnen het MKG-model past deze studie in de rubtieken (1) zorg-en dienstverlening (levering van diensten), (2) beleid en organisatie, en (4) waardering en resultaat (4.2 Resultaatbepaling; 4.4 cliëntenraadpleging; en 4.7 medewerkersraadpleging (tevredenheid binnen het werk). 


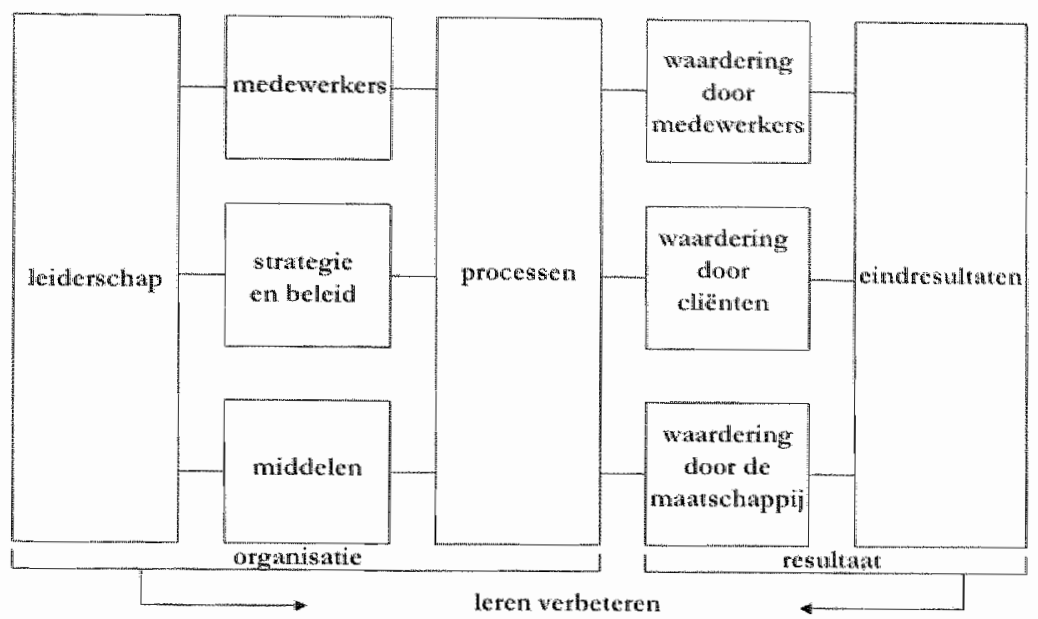

Figutr 4.3 Het INK-managementmodel (INK, 2001a)

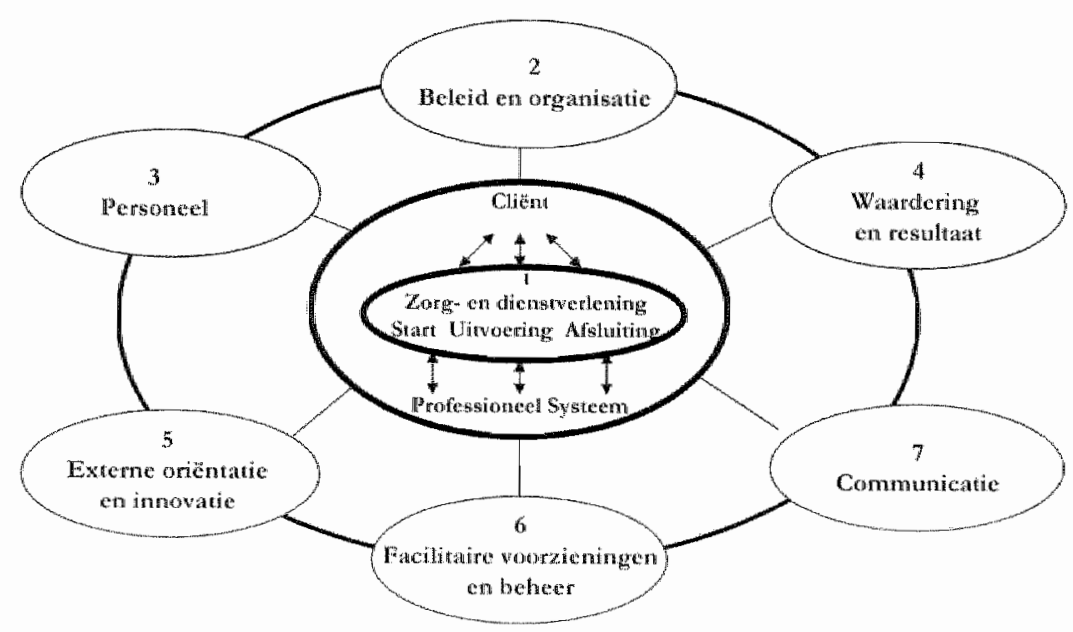

Figuiur 4,4 Het Model Kwaliteitssysteem Gehandicaptenzorg (Vereniging Gehandicaptenzorg Nederiand, $20000 \times$ p. 28 )

Concluderend zal deze studie zich zowel van een inhoudelije als een bedriftsmatige benadering van kwaliteitszorg bedienen. Daartoe zal in hoofdstuk 6 via beide wegen naar een theoretisch model worden toegewerkt. Vanuit kwaliteitsperspectief gaan wij ervan uit dat succesvolle toepassing van kwaliteitsmodellen en -systemen gebaat is bij validering van indicatoren en relaties tussen indicatoren. In deze studie gaat het daarbij om indicatoren van effectief teamfunctioneren, van cliëntevtedenheid en van het verband tussen beide. De nadruk zal daarbij -- in navolging van Capsarie's betoog en van Bitner's en Grönroos' opvatting over relatiemarketing - liggen op de interactic van het team van professionals met het clientsysteem. Continuiteit, cliënttevredenheid en teamfunctioneren zijn daarbij de kernfactoren. 


\subsubsection{Continuîteit en kwaliteit}

"Continuiteit van begeleiding" wordt beschouwd als een belangrijk proceskenmerk van de kwaliteit van begeleiding van mensen met verstandelijke beperkingen (Staring, Duterloo \& Ten Horn, 1993; Driessen, Casparie \& Van den Bos, 1994; Cox, Peeters-Niemantsverdriet, Philipsen, Neumann, Van Campen \& Huyer-Abu Saad, 1994). We gaan hieronder nader in op dit begrip.

Donabedian ziet continuiteit als een kenmerk dat de kwaliteit van zorg nadrukkelijk beïnloedt, maar er als zodanig toch onderscheiden van is. Hij ziet continuiteit eerder als een conditie om tot kwaliteitszorg te kunnen komen. Continuiteit verwijst bij Donabedian sterk naar coördinatie van het zorgproces, voor zover de verschillende onderdelen van zorg ononderbroken en consistent worden geleverd. Centraal staat daatbij het behoud van informatic over eerdere bevindingen, evaluaties en beslissingen uit het zorgproces en de toepassing ervan in actuele zorgpraktijken op een wijze dat stabiliteit in doelen en werkwijzen wordt bereikt (Donabedian, 1980, p. 23-24).

Harteloh en Casparie (1998, p.121) beschouwen continuiteit als indicator in het kader van kwaliteitszorg en onderscheiden continuiteit in Persoon (dezelfde hulpvertener), Tijd en Plaats.

In hun overzichtstudie naar de kwaliteit van thuiszorg aan mensen met een chronische aandoening onderscheiden Cox et al. (1994, p. 15 en 30 ) een veelheid aan discontinuiteiten:

Discontinuiteit in de zorgverlening (afstemming tussen informele en professionele zorgverleners)';

Discontinuiteit in patiëntenloopbaan (onvoorspelbare ontwikkelingen binnen het dagelijks leven van de patiënt);

Discontinuiteit in het persoonlijke netwerk en de informele zorg (discontinuïteit in omvang, structuur en functie van het sociale netwerk);

Culturele en matschappelijke discontinuiteit (problemen in de maatschappelijke constellatie - wijzigende regelgeving bijvoorbeeld - en culturele context waarin besluiten over de zorg tot stand komen).

In deze studie wordt ook een verband gelegd tussen discontinuiteit en dissatisfactie van zorgontvanger en zorgverlener. Personeelswisselingen of verloop wordt in deze studie echtet niet expliciet genoemd als bron van discontinuiteit. In een aan deze studie gerelateerd onderzoek van Sterkenburg, Schneider en Janssen bij ouders van kinderen met verstandelijke beperkingen (1995), vinden de auteurs wel dat de relatief grootste mate van discontinuiteit wordt gerapporteerd in de dimensie 'vervanging' van medewerkers. 
In een studie naar de continuiteit van zotg vanuit clièntenperspectief onderscheiden Casparie et al., 1998) drie dimensies van continuiteit die zij venverkten in de Vragenlijst Continuiteit van zorg vanuit Cliëntperspectief (VCO);

- Aansluiting tussen hulpvraag en hulpaanbod;

Onderlinge afstemming tussen zorgverleners;

Overdracht van de zorg van de ene naar de andere professionele zorgverlener. Binnen deze laatste dimensie maakt de VCC nog een onderscheid tussen (a) overdracht bij verwijzing naar andere hulpverleners of voorzieningen en (b) overdracht russen hulpverleners onderling bij vervanging wegens ziekte of vrije dagen.

Vlaskamp (1997) onderscheidt twee soorten discontinuïteit:

- Inhoudelijke discontinuiteit bejegening en fragmentatie van het zorgprogramma door gebrekkige overdtacht en verdwijnen van kennis over de begeleidingsbehoeften van de cliënt);

- Organisatorische discontinuiteit (personeelsverloop, gebroken diensten, invalkrachten).

Op grond van het voorafgaande stellen wij de volgende vormen van discontinuiteit van begeleiding voor:

Inhoudelijke discontinuiteit: discontinuiteit in de afstemming tussen enerzijds de zorgbehoeften en zorgvragen van het individu en anderzijds de daadwerkelijk geboden zorg. Bewaken van de inhoudelijke continuiteit betekent het regelmatig toetsen of de gevraagde en de geboden zorg (nog) overeenkomen en zonodig bijstellen.

Organisatorische discontinuiteit: doordat verschillende zorgverleners, disciplines en in toenemende mate ook verschillende organisaties bij de zorg rond éénzelfde individu betrokken zijn, vormen de organisatorische voorwaarden voor goede afstemming en overdracht een bijzonder aandachtspunt.

Relationele discontinuiteit: verschillende oorzaken waaronder verloop en personeelswisselingen kunnen de relatie tussen cliënt en zorgverlener verstoren. In situaties van langclurige zorg kunnen daardoor niet alleen functionele en cliëntspecifieke kennis van persoonlijke begeleidingsvragen en -antwoorden verloren gaan, maar ook de wederkerige vertrouwensrelaties tussen organisatie en cliënt met zijn sociale netwerk kan beschadigd taken.

Organisaties die op een bepaald moment goede kwaliteit van zorg leveren, blijken dat na enige tijd niet meer te doen en omgekeerd. Dat hangt samen met congruentie- en consistentiefactoren zoals besproken in paragraaf 2.1. Het gaat er echter om dat er continu goede kwaliteit wordt geleverd, hetgeen afgemeten wordt aan continue cliënttevedenheid. Een belangrijke voorwaarde hiervoor is continuiteit van de dienstverleners. In deze studie staat de kwaliteitservaring van het chëntsysteem centraal. Personeelswisselingen worden gezien als belemmerende 
factor voor de relationele continuiteit in medewerker-cliënt contacten. Deze relatie is dus nict alleen middel, maar ook clocl. Daarom is discontinuiteit een kwaliteitsprobleem. 
Conclusie literatuurstudie en formulering onderzoeksvragen 

Met dit hoofdstuk wordt het eerste deel - een verkennende literatuurstudie afgesloten. In dit deel werd eerst de interne organisatie van residentiele instellingen in relatie tot omgevingsontwikkelingen beschreven vanuit een historisch-sociaal perspectief. Vervolgens werd systematisch de literatuur bestudeerd met betrekking tor personeelswisselingen en relevant gebleken correlaten in de domeinen 'organisatiekenmerken', 'teameffectiviteit' en 'kwaliteit'. Tot slot werd de invalshoek van de marketingdiscipline voor de studie wan teameffectiviteit en kwaliteit in dienstenorganisaties onderzocht. Dit leidt tot de volgende conclusies (paragraaf 5.1) en tot aanpassing van de voorlopige vraagstelling uit paragraaf 1.3 (paragraaf 5.2).

\subsection{Conclusie deel I}

Vetloop van groepsleiders is geen nieuw probleem maar is zo oud als de residentiele zorg zelf. Het hangt nauw samen met de professionalisering van de sector en met de bedrijfsmatige opzet van de begeleiding. Onder invloed van culturele en conjuncturele factoren kan de omvang van het verloop op instellingsniveau variëren; deze factoren zijn uit onderzoek genoegzaam bekend. Over personeelswisselingen op woongroepniveau is echter nauwelijks informatie beschilbaar. Wel stat wast dat petsoneelswisselingen op woongroepniveau gemiddeld genomen een veelvoud bedraagt van het verlooppercentage op instellingsniveau en dat her grootste deel van deze wisselingen door de organisatie zelf worden geinduceerd.

De otganisatie van instellingen wordt sterk beinvloed door hun omgeving. Hierin vinden vooral de laatste decennia grote veranderingen plaats, zowel met betrekking tot demografie, visie op 'handicap', wetgeving, financiering, kostenbeheersing, kwaliteitszorg als met betrekking tot de verwachtingen van cliëntsystemen. Hierdoor ontstaat grote druk voor aanpassing van de interne organisatie.

Complexe veranderingen binnen organisaties vormen echter een risico voor hun interne consistentie en daarmee voor hun effectiviteit: anpassingen in visie, dicnstverleningsprocessen, coördinatie van taken en functies en organisariestructuur lopen niet noodzakelijk met elkaar in de pas. In residentiele organisaties is de service encounter, de plaats waar organisatie en cliènten elkaat ontmoeten, het meest gevolig voor inconsistentie. Binnen deze interface ontvangen cliënten hun diensten en wordt bepald of deze overeenkomen met wat zij verwachten; hier ontstat in belangrijke mate de kwaliteitservaring van het cliëntsysteem.

Uit empirische verloopstudies in residentiële instellingen blijken cen antal intraorganisatorische kenmerken relevant om op te nemen in een studie naar personeelswisselingen. Het gaat om de volgende factoren:

1. instelling als zodanig;

2. omvang van het cluster waartoe de woongroep behoort;

3. sociowoning of woongroep op terrein;

4. grootte van de woongroep;

5. zorgzwaatte van de bewoners. 
Personeelswisselingen moeten worden opgevat als een afzonderlijke bron van inconsistentie, naast of bovenop de hierboven genoemde aanpassingseffecten. Zij vormen een afzonderlijk kwaliteitstisico voor de organisatie. Om die reden is inzicht in dit verschijnsel nutrig voor residentiele organisaties die in Neclerland verantwoordelijk zijn voor de begeleiding van ruim eenderde van alle mensen met verstandelijke beperkingen.

Uit de literatuur blijkt dat personeelswisselingen op verschillende wijzen kunnen worden uitgedrukt al naargelang gekeken wordt naar vaste medewerkers die het team verlaten, of naar nieuwe medewerkers die instromen, of naar de (gemiddelde) tijd die medewerkers deel uitmaken van een team. Dit leidt tot drie modaliteiten van personeelswisselingen of drie typen van maten:

Type I: stabiliteit van het vaste team;

Type II: frequentie van mieuwe instromers in het team;

"Type III: gemiddelde tijd dat de groepsleiders deel uitmaken van het woongroepteam.

Uit een overzicht van verloopstudies komen een aantal televante werkreacties van teammedewerkers als correlaten van personeelswisselingen naar voren. Het gaat om de volgende factoren:

1. arbeidssatisfactie van de teamleden;

2. een complex van werkreacties waaronder ervaren participatie in besluitvorming, samenwerking, overeenkomst tussen eigen waarden en clie van de organisatie, conmitment, werkstress en rolduidelijkheid

Door bestudering van dienstenmarketingstudies blijken deze factoren preciezer omschreven te kunnen worden als factoren wan teameffectiviteit. Het empirische model van Hattline en Ferrell biedt aanknopingspunten voor de studie van de relatie tussen condities voor interne teameffectiviteit van groepsleiders en de door het cliëntsysteem ervaren kwaliteit van begeleiding.

Als effectivitcitscondities wath het teamfunctioneren blijken de volgende factoren van belang:

1. arbeidssatisfactie;

2. rolduidelijkheid;

3. vetrouwen in eigen doelmatigheid;

4. ervaren autonomie.

De extene effectiviteit van het team kan worden afgemeten aan de door het clièntsysteem ervaren kwaliteir van begeleiding. Uit Grönroos' model van kwaliteitsperceptie van cliënten in dienstenorganisaties kan worden afgeleid dat twee aspecten daarbij van belang zijn:

1. de ervaren technische (of inhoudelijke) kwaliteit; en

2. de functionele (of relationele) kwaliteit. 
In de context van kwaliteitszorg vormen 'teameffectiviteit' en "cliënttevtedenheid" relevante indicatoren. Beide houden verband met elkar: zij pormen als het ware twee kanten van dezelfde medaille. In het kader van het doel van deze studie naar personeelswisselingen is het relevant hiermee rekening te houden en derhalve ook dit onderlinge verband nader te onderzoeken.

Personeelswisselingen kunnen in het kader wan kwaliteitszorg worden opgevar als verstoringen van de telationele contrinuiteit van begeleiding. Het ligt roor de hand om aan te nemen dat verstoring in deze contimuiteit merkbaar zullen zijn in zowel de teameffectiviteit als de cliënttevtedenheid, en wellicht ook op het verband tussen beide.

\subsection{Onderzoeksvragen}

Het doel van deze studie is inzicht te verwerven in het verschijnsel personeclswisselingen in woongroepteams van residentiele instellingen voor mensen met verstandelijke beperkingen.

De probleemstelling studie luidt: "Wat is de samenhang tussen personeels" wisselingen $(\mathrm{PW})$, organisatiekenmerken $(A)$, teameffectiviteit $(B)$, en de door het diëntsysteem ervaren kwaliteit van begeleiding (C)?" (figuur 5.1)

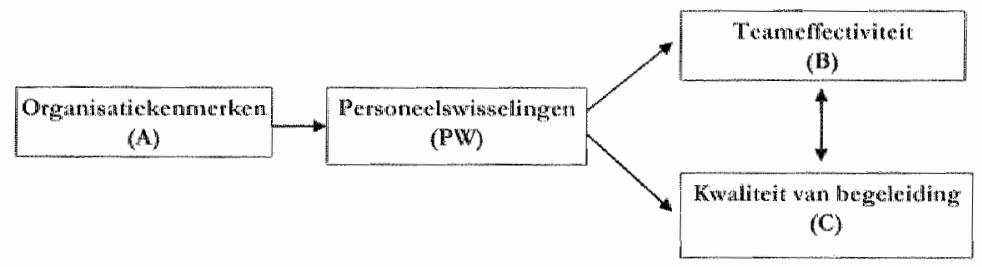

Figuur 5.1 Kemelementen wan de probleemstelling

Op basis van de resultaten van de literaturverkenningen kunnen de vootopige onderzoeksvragen uit paragraaf. 1.4 nu nader worden uitgewerkt. Dit leidt tot de volgende bijgestelde onderzoeksvragen:

1. Is er een verband tussen organisatickenmerken en personeelswissclingen in residentiële instellingen voor mensen met verstandelijke beperkingen? ( $A$ $\mathrm{PW})$

Als relevante organisatickenmerken $(A)$ vonden we: de instelling als zodanig, het clusterverband van de woongroep, de locatie van de woongroep (sociowoning), de grootte van de woongroep, cn de zorgzwaarte van de woongroep.

2. Is er een verband tussen personeelswisselingen en de effectiviteit van het teamfunctioneren (interne effectiviteit)? (PW-B)

Uit de marketingliteratuur blijken de volgende aspecten wan het teamfunctioneren (B) relevant voor de effectiviteit: arbeidssatisfactic, rolduidelijkheid, vertrouwen in eigen functioneren en ervaren autonomie. 
3. Is er een verband tussen personeelswisselingen en de door het cliëntsysteem ervaren kwaliteit van begeleiding (externe effectiviteit), te onderscheiden in technische of inhoudelijke en functionele of relationele kwaliteit wan begeleiding? (PW-C)

4. Is er cen verband tussen de effectiviteit van het teamfunctioneren en de door het clientsysteem ervaren kwaliteit wan begeleiding? $(\mathrm{B}-\mathrm{C})$

5. Spelen personeelswisselingen een tol bij het eventuele verband tussen de effectiviteit van het teamfunctioneren en de door het cliëntsysteem ervaren kwaliteit van begeleiding? (PW-B/C)

6. Hoe kan de door het clièntsysteem ervaren kwaliteit van begeleiding door de combinatie van de factoren organisatiekenmerken, personeelswisselingen en teameffectiviteit het best worden verklaard? $(A-P W-B \rightarrow C)$ 


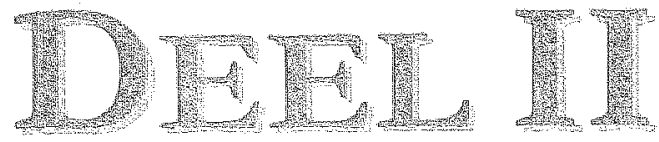


Theoretisch kader 

In dit hoofdstuk wordt de probleemstelling binnen een theoretisch kader geplantst. Omdat een dergelijk kader in de literatuur tot nu toe niet wordt aangetroffen, wordt getracht dit te construeren op basis van zowel een inhoudelijke als een organisatiegerichte benadering. Dit hoofdstuk begint met een bespteking van de relevantie van de omgeving voor het functioneren van mensen met verstandelijke beperkingen (6.1). Vervolgens worden de sociale ecologie als inhoudelijk theoretisch model (6.2) en de marketingbenadering als organisatiegericht theoretisch model (6.3) voor de studie wan personeelswisselingen beschreven. Er zal worden beargumenteerd dat dit twee weliswaar verschillende, maar uiteindelijk congruente theoretische kaders zijn voor het doel van onze studie. Binnen paragtaaf 6.3 zal eveneens worden beargumenteerd dat het woongroepteam voor het functioneten van bewoners van residentiële instellingen een cruciale ecologische factor vertegenwoordigt; de effectiviteit van het functioneren van dit team staat rechtstreeks in verband met de door cliënten ervaren kwaliteit van begeleiding. Ook wordt binnen deze paragraaf aandacht besteed aan conceptuele en methodologische problemen van het meten van cliënttevredenheid. Op basis van in de literatuur gerapporteerde empirische toetsing van beide theoretische modellen zullen richtinggevende stellingen voor ons onderzoek worden geformuleerd. Dit hoofdstuk wordt afgesloten met de constructie van het theoretisch kader voor ons onderzoek en de herformulering van de voorlopige onderzoeksvragen uit hoofdstuk 5 .

\subsection{Verstandelijke beperkingen en omgeving}

\subsection{1 'Handicap': een functionele visie}

De publicatie door de World Health Organization (WHO) van de "International Classification of Impairments, Disabilities and Handicaps"' (ICIDH) in 1980, markeert een keerpunt in het denken over 'handicap'. Vóót die tijd overheerste een pathologische visie waarin een handicap meestal gelijk werd gesteld met cen ziekte of aandoening of met de chronische effecten hiervan op lichamelijke of psychische functies. De locus van het probleem ligt binnen het individu. 'Cretinisme', 'syndroom van Down', 'fenylketonurie', 'fragile-X syndroom' en Prader-Willi syndroom zijn voorbeelden van aandoeningen. Benamingen van 'handicaps' zoals blind, doof, kreupel, zwakzinnig zijn voorbeelden van aanduidingen van stootnissen in de zintuigen, motoriek of mentale functies. Het nadeel van de pathologische visie is dat in het geval de aandoening niet te genezen is of de stoornissen niet gecompenseerd of gemitigeerd kunnen worden, de bemoeienis van de gezondheidszorg gereduceerd wordt tot verzorging of verpleging. Vanaf de jaren vijftig van de rwintigste eeuw wordt deze visie steeds minder acceptabel gevonden. Mensen met chronische aandoeningen rapporteren dat de reacties van de samenleving op hun stoornis en de belemmeringen die men antreft in attitudes en toegankelijkheid wan de omgeving, erger te vinden dan de stoornis zelf (Braddock \& Parish, 2002; WHO-FIC, 2002). 
De $1 \mathrm{CMDH}$ introduceert een meerdimensionale kijk op het 'menselik functioneren' (figuur 6.1). Dit model makkt een onderscheid tussen 'aandoeningen', die als etiologie kunnen worden beschouwd, en de consequenties hierwan voor het functioneren op drie niweaus: op organ niveau (stoomissen), op niveau van activiteiten vatu het indrvidu (beperkingen) an op niveau van de respons van de samenleving op de anwezigheid van stoomissen en beperkingen bij de persoon (handicap). Het toevoegen van de invalshoek van de samenleving leidde tot de mogelikheid sociale nadelen te formuleten die de persoon ondervindt bij de uitoefening van rollen (in gezin, school, werk, samenleving) als gevolg wan stoomissen en/of beperkingen. "Handicap" weerspiegelt dethalve de culturele, sociale en economische consequenties voor het inclividu van de aamwezigheid van stoornissen en beperkingen. Deze laatste invalshoek wordt vanaf de jaren tachtig zo belangtijk gevonden dat het begrip "handicap" als een pars pro toto wordt gehanteerd voor het geheel van problemen in het functioneren.

Het ICIDH model wervult vanaf 1980 een belangrijke rol in de conceptualisering wan "handicap' en darmee in de (internationale) communicatie tussen verschillende disciplines en in wetenschappelik onderzock (Habertsma, 1995; Ten Horn, 1997; Ketsten \& Schunurman, 2000j.

\begin{tabular}{l|l|l|l|l} 
Kembegrj] & Ziekte / andoening $\Rightarrow$ & Stoomis $\Rightarrow$ & Beperking $\Rightarrow$ & Handicap \\
\hline Perpectice & Pathologe & Organ(functic) & Activitei & Sociahe context
\end{tabular}

Figuur 6.1 Relatie tussen de kembegrippen en perspectieven wan de $\mathbb{1 C I D H}$

Er kwan ook kritiek op de ICIDH. Deze had betrekking op:

De sterke suggestie van causaliteit in de sequentie "aandoening $\Rightarrow$ stoornis $\Rightarrow$ beperking $\Rightarrow$ handicap'. Betoogd werd dat eerder sprake is van interactic tussen de kemelementen. Met andere woorden: elk element kan elk ander element in het model in elke richring beinvloeden. Het is zelfs denkbaar dat belemmeringen in het participeren in de samenleving (bijvootbeeld ten gevolge van discriminatie in woon-, school- of werksituaties) kunnen leiden rot het frustreten van leermogelijkheden, tot langdurige stress en daardoor zelfs tot stoomissen en andoeningen.

De negatieve terminologie die stigmatiserend zou werken.

Het onderwatedert van de rol van de sociale en matschappelijke omgeving als bevorderende of belemmetende factor voor het functioneren (Fougeyrollas, 1998; Halbertsma, Heetkens, Hirs, de Klejn-de Vrankrijker, Van Ravensburg \& Ten Napel, 1999; Kraijet; 1993; Rioux, 1997; WCC, 1994)

Na een grondige revisie publiceet de WHO in december 2001 de opvolger van de ICIDH: de Intemational Classification of Functioning, disability and health (ICF) (figum: 6.2). 


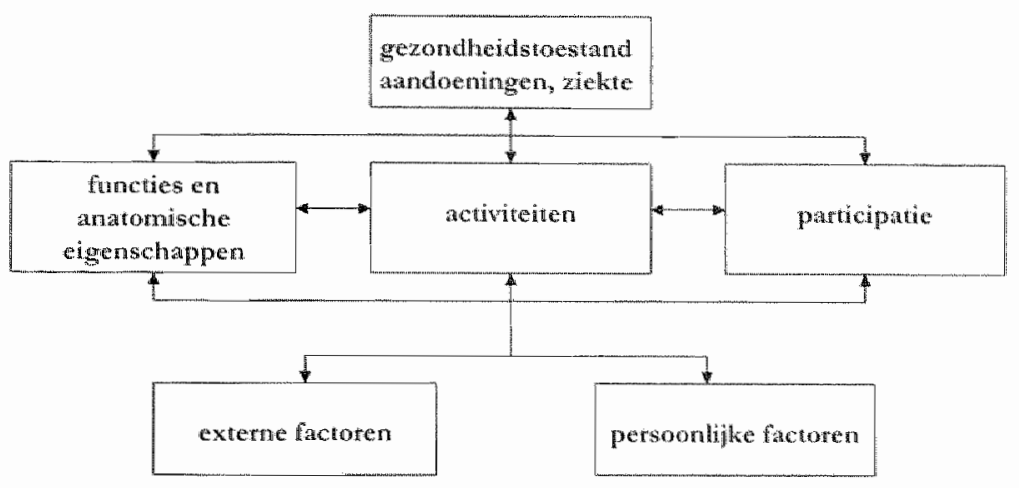

Figuur 6.2 Model van het menselijk functioneren volgens de ICF (WHO-FIC, 2002)

De aanpassingen in het model betreffen ten eerste de principiële keuze voor een gegeneraliseerd model van het menselijk functioneren dat relevant is voor het beschrijven van zowel 'gewoon' als 'problematisch' functioneren. Ten tweede werd het kemelement 'context' (exteme factoten en persoonlijke factoren) roegevoegd. Ten derde geeft het nieuwe model beter de complexe interacte tussen de verschilende elementen weer. Ten vierde wordt gebruik gemaakt wan posirieve terminologie; de begtippen stoornissen, beperkingen en handicaps verwijzen naar problematische situaties in respectievelijk de 'functies en anatomische eigenschappen', de 'activiteiten' van de persoon, en zijn maatschappelijke 'participatie' (WHO-FIC, 2002).

'Exteme factoren' verwijzen naar omgevingskenmerken die het functioneren van mensen kunnen bevorderen of belemmeren. Dat wil zeggen dat zij - in interactie met aandoeningen - een positieve of negatieve invloed kunnen uitoefenen op het functioneren van de persoon.

Naast (1) producten en technologie en (2) natuurlijke omgevingen, maken (3) ondersteuning on relaties, (4) attitudes van de omgeving en (5) de beschikbatheid en toegankelijkheid van diensten en systemen, deel uit van de omgeving. Extence of omgevingsfactoren werken in op elke dimensie van functioneren èn op aandoeningen. Wanneer het functioneren van een persoon wordt beïnvloed door een (chronische) aandoening, kan de beschikbarheid en de effectiviteit van medicijnen, technologische ingrepen en hulpmiddelen, hulpverleners, diensten, regelgeving en beleid dus tot minder of tot meer problemen leiden in het functioeren (stoomissen, beperkingen en participatieproblemen). Deze laatste visie benadrukt het belang van cen toegankelijke omgeving, van het recht op ondersteuning en van politieke en juridische instrumenten om dit te bewerkstelligen.

Door de combinatie van zowel het functionalistisch-objectivistisch als het sociaalsysteem perspectief op het verschijnsel 'handicap', reptesenteert de ICF in wetenschappelijk opzicht een multi-paradigmatisch model (Mercer, 1992; Switzky 
\& Greenspan, 2003). Dit makt het mogelijk on zowel de impact van aandoeningen en stootnissen binnen de persoon als de impact van beperkende cxterne omstandigheden én van hun interactie op een pragmatische manier te combineren (Climens, 2003).

\subsubsection{Verstandelijke beperkingen en omgeving}

In het meest recente theoretische model van 'verstandelijke beperkingen' van de American Association on Mental Retardation (AAMR) worden de dimensies van de ICF teruggevonden (Luckasson et al., 2002; Buntinx, 2002). Het AAMR-model schenkt daarenboven expliciet aandacht aan de rol van ondersteuning voor het functioneren van het individu (figuur 6.3). Daarmee is het niet alleen een beschrijvingsmodel zoals de ICF maar ook een handelingsmodel.

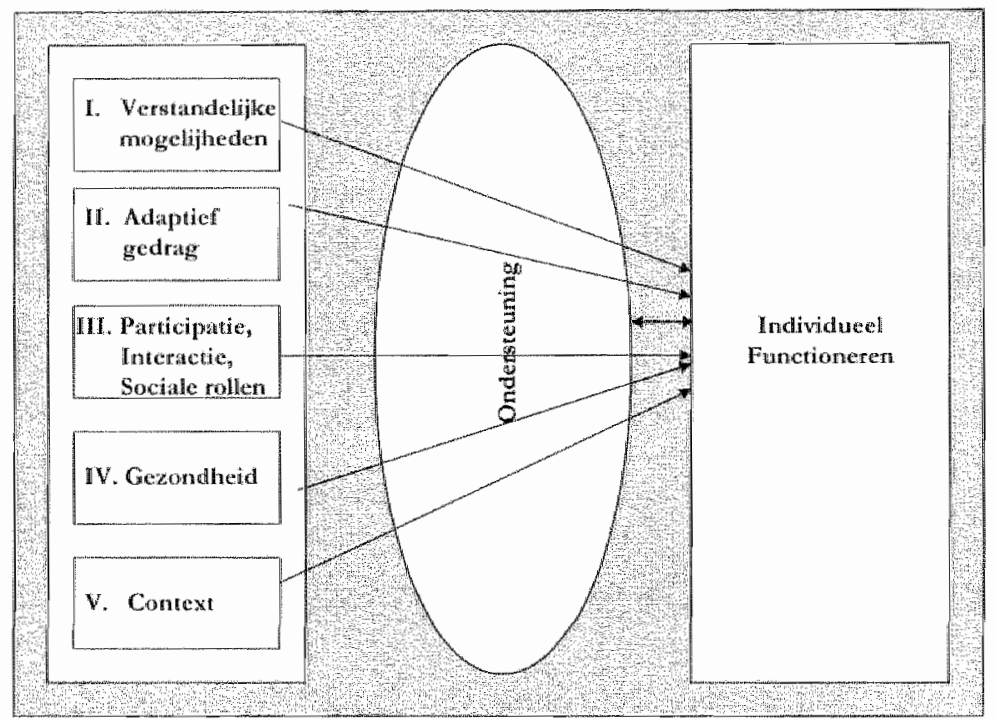

Figutur 6.3 Theotetisch model wan "werstandelijke beperkingen" volgens de AAMR (Luckasison et al, 2002)

Het $M A M R$-model laat zien dat ondersteuning betrekking heeft op alle dimensies van functioneren en daarop een direct effect uitoefent. Omgekeerd beinvloedt het functioneren ook de ondersteuning. Zo leidt bijvoorbeeld een succesvolle verruiming van vaandigheden om zelistandig te kunnen wonen en reizen (dimensie II: adaprief gedrng) tot andere ondersteuningsbehoeften dan voorheen. Maar ook tot nieuwe mogelijkheden (bijwoorbeeld op gebied van werk en vrije tijd) die op hun beurt weer een aangepaste ondersteuning vragen. Een ander voorbeeld betreft een voortschrijdend verouderingsproces waardoor lichamelijke functies en vaardigheden afnemen (dimensie IV en II) en waardoor ondersteuning rekening moet houden met een meer beschermende woonomgeving (dimensie V). Gebrekkige of onjuiste ondersteuning - bijvoorbeeld door het ontbreken van voldoende en aan- 
gepaste dagbesteding, of door overbescherming waardoor mogelijkheden van de persoon niet worden aangesproken en geen kans krijgen, of door frequente personeelswisselingen - kan leiden tot toename van functioneringsproblemen en vergroot derhalve de 'handicap'.

Het AAMR model gaat ervan uit dat ondersteuning die rekening houdt met de vetschillende dimensies van functioneren en gebruik maakt van relevante hulpbronnen, leidt tot verbetering van het functioneren van een persoon met verstandelijke beperkingen. 'Verbetering' moet zowel objectief als subjectief worden opgevat, en dus als 'kwaliteit van bestaan' (Van Gennep, 2000; Schalock \& Verdugo, 2002). Indien een bepaalde ondersteuningstrategie in de praktijk niet zou leiden tot verbetering van het functioneren is dit reden tot het opnieuw analyseren en in kaart brengen van de functioneringsdimensies (assessment) en het bijstellen van het ondersteuningsplan (Luckasson et al., 2002; Buntinx, 2003a). De nadrukkelijke functie van ondersteuning verklaart waarom dit model ook wel het 'ondersteuningsparadigma' (support paradigm) van verstandelijke beperkingen wordt genoemd.

\subsubsection{Het ecologisch karakter van ondersteuning}

Het ondersteuningsconcept is gebaseerd op twee uitgangspunten.

Het eerste uitgangspunt is het wetenschappelijke paradigma van het contextualisme of het ecologisch model. Dit stelt dat het functioneren van mensen begtepen moet worden vanut de interactie tussen individu en omgeving. Twee zaken zijn daarbij van belang. Ten eerste, verwijst 'omgeving' in dit verband niet alleen naar de directe fysieke en sociale setting waarin het individu zich bevindt, maar ook naar de bredere omgeving warbinnen deze setring is ingebed: organisaties, instituties, culturele en historische situaties. Ten tweede, de interactie tussen individu en omgeving is dynamisch. Dat wil zeggen dat omgevingen niet constant zijn, mat dat ook individuen geen constante zijn in hun interactie met de omgeving. De omgeving beinvloedt gedrag en ontwikkeling van mensen, mar mensen oefenen zelf ook invloed uit en veranderen hun omgevingen. Daarenboven vetanderen mensen door ontwikkeling en veroudering.

Het tweede uitgangspunt is normatief en betreft het social-politieke beginsel van het egalitarisme. Dit stelt dat alle mensen op sociaal, politiek en economisch gebied gelijke rechten bezitten. Dit gelijkheidsbeginsel is verankerd in het handvest van de Verenigde Naties (1945) en in de Universele Verklaring van de Rechten van de Mens (1948). In 1971 aanvaardden de Verenigde Naties de Universele Verklaring van de Rechten van Verstandelijk Gehandicapten, gevolgd in 1975 door de Verklaring valu de Rechten van Mensen met een Handicap. Beide laatste verklaringen bevestigen en verbijzonderen voor mensen met een handicap het gelijke recht op toegang tot sociale, politieke en economische hulpbronnen van de samenleving alsmede het individuele recht op nastreven van persoonlijke ontplooiing en geluk. De social-politieke condities voor deze gelijkheid werden door de Verenigde Naties als internationale richtlijn vastgelegd in de Standard Rutes on the Equatization of 
Opportunitivs for Persans with Disabilities (Federatie van Ouderverenigingen, 1999; Gorter, Bougie \& Van der Pijl, 2000; United Nations, 1994). In Nederland en Vlanderen is dit uitgangspunt bekend als het Burgerschapsparadigma (Van Gennep, 1997; Van Gennep en Steman, 1997; Van Gennep, 2000). Her ondersteuningsconcept is daamee zowel wetenschappelijk als maatschappelijk gesitueerd.

De AAMR definieert ondersteuning als het geheel aan hulpbronnen (resources) en strategicën om de ontwikkeling, de opvoeding, de belangen, het persoonlijke welzijn en het algemene individuele functioneren van mensen met verstandelijke beperkingen te bevorderen. Het individuele functioneren is het resultaat van de interactie tussen enerzijds de competenties van het individu in relatie tot de eisen en verwachtingen van de omgeving en anderzijds de ondersteuning die een persoon ontvangt.

Er worden twee soorten ondersteuningssystemen onderscheiden.

Naturlijke onderstetningssystemen. Deze zijn de persoon zelf (gebruik makend van eigen vaardigheden en persoonlijke hulpbronnen) en personen en hulpbronnen die beschikbaar zijn in de natuurlijke omgeving van de persoon. Te denken valt aan ouders, familieleden, en vrienden, maar ook aan buren, collega's, medeleerlingen en ook aan algemene (voor alle burgers beschikbare en toegankelijke) voorzieningen van de samenleving op gebied van bijvoorbeeld transport, huisvesting, onderwijs, werk, vrije tijd, gezondheidszorg, winkelen, informatievoorziening.

Gespecialiseevde ondersteumingssystemen. Dit zijn personen en dienstenorganisaties die zich special richten op het ondersteunen van mensen met een (verstandelijke) handicap zelf, hun familie en vrienden, maar ook op professionals in de algemene dienstverlening. Het betreft medewerkers die een opleiding of training hebben genoten en die zich individueel of in de context van een dienstenorganisatie special bezig houden met (ondersteunings)problemen van mensen met verstandelijke beperkingen. Voorbeelden zijn: persoonlijke assistenten en begeleiders, activireitenbegeleiders, leraten in her speciaal onderwijs, job coaches, pedagogen, psychologen, AVG-artsen, maatschappelijk werkers en consulenten. Een huisarts die iemand met verstandelijke beperkingen behandelt behoort tot de 'naturlijke ondersteuningsbronnen'; een AVG-arts die zijn collega daarbij adviseent of assisteert behoort tot de 'gespecialiseerde ondersteuningsbronnen'.

Ondersteuningssystemen kunnen in concentrische cirkels worden weergegeven (figuur 6.4) waarbij de persoon zelf (1) in het centrum staat; daar omheen staan familie en vrienden (2); vervolgens informele contacten (3) zoals buren, collega's, medeleerlingen en vrijwilligers; dan volgen algemene zorg-en dienstverlening (4); en uiteindelijk gespecialiseerde zorg-en dienstverlening (5) (Luckasson et al., 2002, p. 185). Deze ondersteuningssystemen worden ook wel aangeduid met de begrippen 'sociale netwerk' van de persoon (cirkel 2 en 3 ) en 'sociale vangnet' (cirkel 4 en 5) (Van Gennep \& Steman, 1997).

Het ondersteuningsparadigma houdt in dat zoveel als mogelijk ondersteuning plats vindt binnen het natuurlijke systeem in de eigen ongeving van de persoon (de 
cirkels $1,2,3,4$ ) en dat het gespecialiseerde systeem (cirkel 5) in de eerste plaats het natuurlijke ondersteunt en daat niet onnodig woor in de plants kont. Onze studie heeft betrekking op residentiele instellingen, en dus op gespecialiseerde systemen. Naarmate deze instellingen als altematief voor een verblij $f$ in de samenleving worden opgevat omvatten ze meer plaatsvervangende functies (paragtaaf 2.2.1).

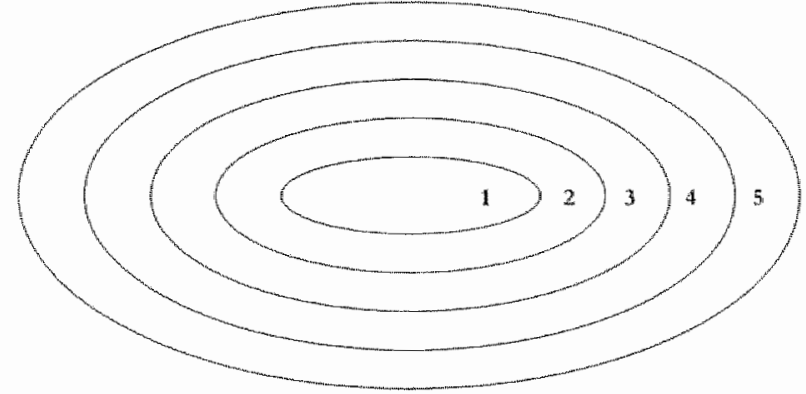

Figuur 6.4 Ondersteuningssytemen volgens de AAMR (Luckasson et al., 2002, p.185) (Verklaring: xie telkst)

Het ecologische karakter van 'verstandelijke beperkingen' en van 'ondersteuning" betekent dat de activiteiten van een gespecialiseerde instelling niet los kunnen worden gezien van de overige ondersteuningssystemen. Wetenschappelijk onderzoek van situaties waarin mensen met verstandelijke beperkingen zich letterlijk binnen de organisatie bevinden (daar wonen, dagbezigheden hebben en recreëren), heeft behoefte aan een nader uitgewerkt theoretisch model waarin relaties tussen de persoon, zijn familie en professionele hulpverleners worden verhelderd. Voor de organisatie is het wan cruciaal belang de inferface of het raakvlak tussen organisatie en cliëntsysteem goed te begrijpen. De sociale ecologie biedt daartoe mogelijkheden. In de paragraaf 6.2 wordt de sociale ecologie toegelicht. Dit theoretisch model maakt het mogelijk een inhoudelijk verband te leggen tussen het functioneren (van mensen met verstandelijke beperkingen), ondersteuning en de organisatie van ondersteuning. In paragraaf 6.3 wordt daama een verband gelegd tussen (de ervaring van het) functioneren, ondersteuning en organisatie van ondersteuning aan de hand van een marketingmodel. Beide benaderingen blijkern congruent te zijn. Dat betekent dat de organisatorische invalshoek om personeelswisselingen te bestuderen congruent is met de inhoudelijke invalshoek en hiermee niet in tegenstelling is.

\subsection{De sociale ecologie}

De ecologie heeft haar wortels in de biologie waar de term voor het eerst werd gebruikt door de Duitser Enst Haeckel (1834-1919). Hij verwees hiermee naar de relaties van een organisme met zijn organische en anorganische omgeving - een zienswijze die voor het eerst door Theophrastus (372-287 w.Chr.) in zijn studies over planten werd geformuleerd. Het begrip 'ecologie' heeft de Grickse stam 'oikos', hetgeen 'huis', 'huishouden', 'woonplats' betekent. Het betteft overigens dezelfde stam als in het begrip 'economie'. In ruime zin verwijst ecologie naar de 
studie van de relaties tussen organismen en hun omgeving (Smith, 2004). Wetenschappers als Kurt Lewin en Roger Barker introduceerden een ecologische benadering in de psychologie voor zover zij gedrag niet vanuit persoonspecifieke kenmerken zoals aangeboren disposities en personnlijkheidstrekken trachtten te verklaren, maar de invloed wan de context mede als verklaringsgrond van gedrag namen. Deze context kan worden opgevat als de subjectieve beleving van de omgeving door het individu en de psychische organisatie daarvan (Lewin) of als objectieve kenmerken die de waarschijnlijkheid van een bepaalde gedragsrespons beinvloeden (Barker) (Barker, 1965; Lewin, 1935; Fuhrer, 1990). Het model kan worden samengevat in de formule $B=f(P \times E)$. Gedrag (Behavior) is functie van de interactie van persoon (Person) en omgeving (Environment) (Lewin, 1935, p. 73).

Het ecologische model werd eveneens geintraduceerd in de sociologie, epidemiologie, psychiatrie en organisatietheorie. Waat het gaat om de studie van sociale en sociaal bepaalde omgevingen (inclusief organisaties, instituties en culturen), spreekt men wan 'sociale ecologie'. Toepassing van het theoretische model vond plaats in studies op het gebied van de menselijke ontwikkeling (Btonfenbrenner, 1979, 1986, 1994 \& 1999; Friedman \& Amadeo, 1999; Moen, Elder \& Lüsher, 1995; Stokols, 1999), geestelijke gezondheidszorg en psychopathologie (Cicchetti \& Cohen, 1995; Moos, 1974; Moos \& Insel, 1974), onderwijs (Talbert \& Mclaughglin, 1999), organisatiekunde (Hannan \& Freeman, 1977; Hrebiniak \& Joyce, 1985) en in de zorg voor mensen met verstandelijke beperkingen (Berkson, 1978; Garber, 1988; Hellet, Miller \& Hsieh, 2002; Landesman, Dossett \& Echols, 1996; Nihira, Weisner \& Bernheimer, 1994; Romer \& Berkson, 1980; Schalock \& Kieman, 1990; Schoggen, 1978). Het ecologische model is bij uitstek geschikt voor het integreten van multidisciplinaire benaderingen van omgevingen (Moos, 1974).

De sociale ecologie wordt niet alleen gebruikt als wetenschappelijk model voor onderzock maar ook als teferentiekader voor klinische en praktische toepassingen zoals behandeling wan gedragsproblemen en integratievraagstukken (Berry, 1995; Dunn, Brown \& McGuigan, 1994; Van Gennep, 1995a, 1995b; Van der Ploeg, 1990; Schartman, 2001; Vermeer, 1997). Praktijktoepassing wordt mede bevorderd door de impliciete waardegerichtheid van de sociale ecologie: de relatie tussen organisme en omgeving wordt bekeken vanuit het perspectief de overleving(skansen) of de kwaliteit van het functioneren van het 'organisme' (individu, groep, organisatic) te bevonderen. Sociale ecologie is gericht op het verzamelen en aanwenden van kennis in relatic tot het zo effectief mogelijk functioneren van mensen en het verbeteren wan de kwaliteit vatn hun omgeving (Moos, 1974).

Her begrip 'sociale ecologie' wordt in de literatuur in twee betekenissen gehanteerd. De eerste betekenis stelt de interactie tussen mens en omgeving als zodanig centraal. Dit perspectief wordt met name door Bronfenbrenner gehanteerd en betreft een (longitudinale) procesbenadering. De tweede betekenis stelt de omgevingsfactoren en de samenhang tussen omgevingsfactoren van uiteenlopende aatd 
central, root zover deze relevant zijn woor het functioneren van mensen (Landesnan, Dossett \& Echols, 1996). Beide benaderingen zijn complementait.

We zullen nu aan de sociaal ecologische theorie een aantal basisconcepten ontlenen voor de constructie van het theoretisch model van onze studie. Datartoe wotden de structuur van de ongeving en een aantail relevante processen besproken.

\subsubsection{Conceptualisering van de ondersteuningsomgeving}

Volgens Bronfenbrenner kan de omgewing worden opgevat als een hierarchie wan geneste strucruren rond het individu, te vetgelijken met con ser in elkat passende Russische poppen. De meest directe omgering rond het indridu is opgenomen binnen een datromheen liggende structuur die op haar beurt weer is genest in een hogere structuur. Deze stucturen zijn met elkat verbonden en vertonen wisselwerking; gebeurtenissen in én omgevingsstructum leiden tot effecten in de andere. Het gaat binmen elk van deze structuren om dynamische en met alkat samenhangende processen waarin het individu direct of indirect is betrokken; hij spreekt dan ook van systemen. Bronfenbrenner definieent de volgende systemen (Bronfenbrenner, 1979 , P. 21-42; 1986).

Het microsystem: een patroon van activiteiten, rollen en interpersoonlijke relaties die de persoon ervat binnen een gegeven setting.

Een setring is een plats waar face-to-face relaties kunnen plaatsvinden zoals bijvoorbeeld het gezin, een club, een woongtoep van een residentiele instelling of een activiteitengroep. Het begrip 'erwaart' verwijst zowel naar subjectief ervaren als naar objectieve kenmerken van de omgeving. 'Activiteiten, rollen en relaties' zijn de bouwstenen van een microsystem. Deze actimitaten, rollen en relaties moten regetmatig en over een langere tijdsperiode platswinden on een effect op bet functioneren te bebber.

Het mesosystem: de verzameling van twee of meer microsystemen waarin de persoon participeert en de wederzijdse relaties tussen deze settings.

Het mesosysteem is dus een systeem van microsystemen zoals bijwoorbeeld voot: een client van een residentiële instelling, de woongroep, zijn familie, de activiteitengroep of schoolklas.

Het exasyseem: dit verwijst naat éen of meerdere setrings waarin de persoon niet direct persoonlijk en actief aanwezig is, maar warbinnen gebeurtenissen plaatsvinder die invloed hebben op, of worden beinvloed door de settings warin de persoon functioneert. Het betreft bijwootbeeld andere woongroepen in dezelfde instelling, een organisatiecluster waartoe de woongroep behoort, management organen van de instelling waaronder ook bewoners- en cliëntenraad, andere instellingen in de regio, zorgkantoren, maar ook de werkluing van ouders of hun wriendenkring. 
Het yolosystems: dit verwist nate de consistentie naat vorm en inhoud van micro-, meso- exs exosystemen op thet hyeau van de cutuur of samenleving (nate).

In de residentide zotg voor mensen met verstandelike beperkingen gat het on de wet-en regelgeving, beledswisies cn hulpverleningsconcepten die relevant zipn woor de datonder liggende systomen. Bijvoorbeeld gat het om de $A W B Z$, de systemen wh indtcatestelling en financieting, de $B O P Z$, concepten als "Kwaliteit van Bestarn', en wetenschappelifke modellen van 'handicap' zoals de besproken ICF er het AMR model.

Het whowasystom, betreft de tipdsdimensie die het mogeligk makt veranderingen in de cetder genomde systemen en de ontwikkeling van de persoon te beschijven.

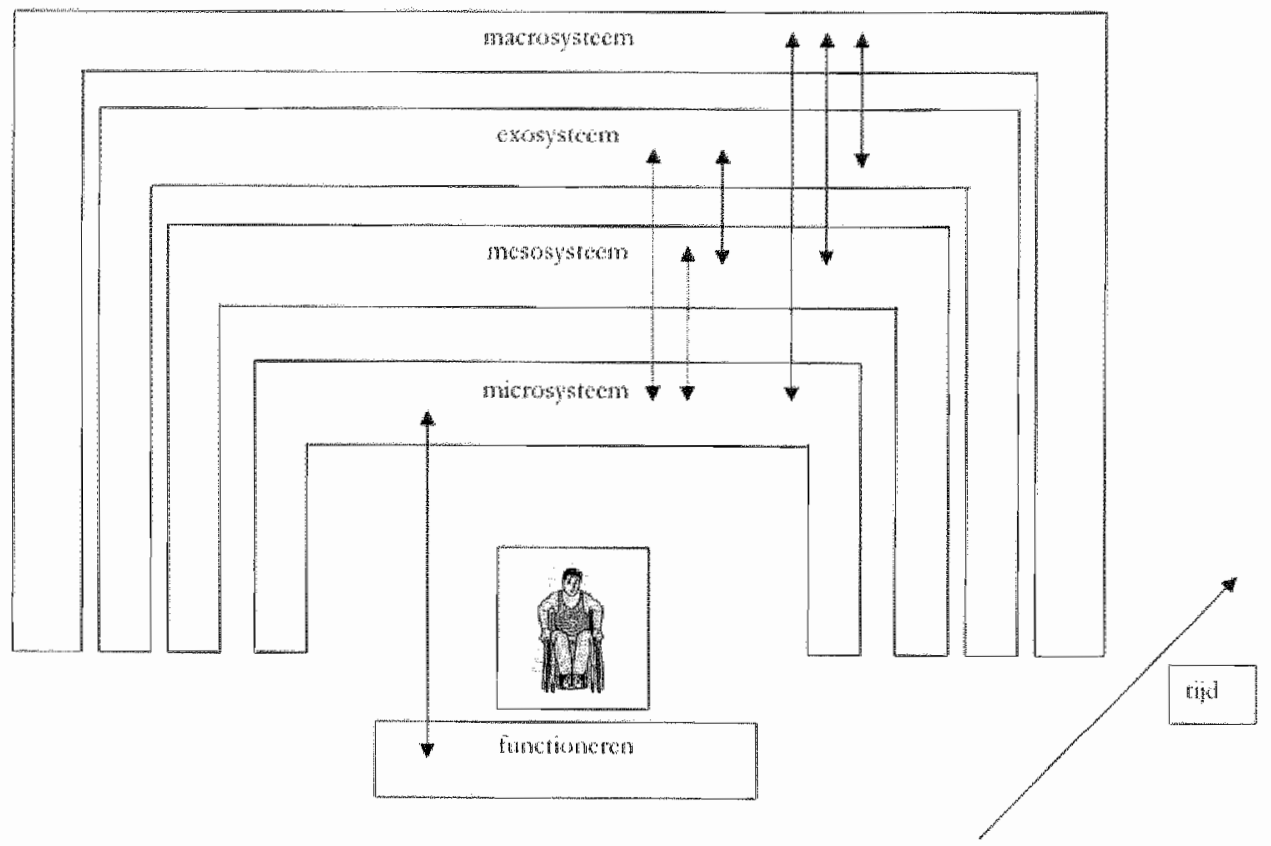

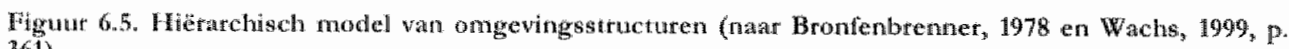
361)

Figur 6.5 illustreet global de structuur van de ongeving. In werkelijkheid zijn de geneste structuren veel complexer onder meer omdat binnen het mesosysteem van een persoon meerdere microsystemen thuishoren: een persoon funcrioneert immers binnen meerdere microsystemen zoals gezin, schoolklas, werksituatie, woongtoep. De hogere structuren kunnen een rechtstreeks mar ook een mediërend of een modererend effect hebben op processen binnen de lagere structuren. De velaties tussen de verschillende systemen zijn niet symmetrisch: de impact van 'hogere' systemen op het individu is groter dan ongekeerd. 
Naast de verschillende niveaus van de omgeving kunnen verder verschillende dimensies van de omgeving worden onderkend. Hier zijn vele invalshoeken mogelijk, maar de meest gangbare zijn (Moos, 1974; Schalock \& Kiernan, 1990):

1. geografische en klimatologische aspecten;

2. Fysieke en architectonische kenmerken;

3. organisatiekenmerken (structuur, processen en stabiliteic);

4. kenmerken van personen die zich binnen de setring bevinden (bijwoorbeeld medebewoners en begeleiders);

5. het sociale limat (de omgeving zoals de persoon die ervatr);

6. de functionele kenmerken van de omgeving: dit zijn de discriminatieve stimuli en de respons van de omgeving op her gedrag van het individu.

Voor onze studie over personeelswisselingen zijn vooral de dimensie 3,4 en 5 van belang.

De impact van alle systemen culmineert in de persoonlijke interacties die het individu heeft binnen zijn microsystemen. Microsystemen mediëren als het ware de invloed wan alle andere systemen. De elementaire bouwsteen van deze persoonlijke interacties is de dyade. Een dyade bestaat uit een één op één relatie van twee personen waarvan eén het beschouwde individu is (bijvoorbeeld een bewoner in een woongroep van een residentiële instelling) en de andere een persoon uit her beschouwde microsysteem (bijvoorbeeld een groepsleider of een familielid). Een dyade is pas relevant binnen de context van doelgerichte, concrete activiteiten die in tijd en plaats kunnen worden gedefinieerd (molare activiteiten). Dit kan bijvoorbeeld zijn: samen deelnemen aan een maaltijd, TV kijken, voorlezen, samen winkelen, een uitstap maken of het samen doen van huishoudelijke acriviteiten. Kenmerken van de dyade zijn (1) reciprociteit (wat $A$ doet beinvloedt wat $B$ doet en vice versa), (2) balans (de bewoner heeft kans om invloed uit te oefenen op de situatie en on zelfstandiger te functioneren; verschillen in macht of invloed van betrokkenen worden positief ten voordele van de bewoner aangewend), en (3) een affectieve relatie tussen de personen van de dyade (deze kan positicf, negatief of ambivalent zijin).

De activiteiten en relatiepatronen binnen de dyade worden mede bepaald door de verwachtingen van de samenleving. Het gaat daarbij on sociale rollen die vervuld worden: bijvoorbeeld die van 'client van de instelling' en van 'groepsleider'.

De dyades van bewoners en groepsleiders in een woongroep zijn dus van uitermate groot belang in het kader van de effectiviteit en de kwaliteit van de hulpverlening. Dyades zijn de daadwerkelijke platsen van ontmoeting van de bewoners met het team van groepsleiders; het zijn de uiteindelijke interfaces tussen clienten en verder alles war de organisatie, haar functie en haar inbedding binnen een bredere context van beleid en regelgeving voor staat. Met andere woorden, de waarden zoals dic zijn opgenomen in de missie en de visie van de insteling maar ook in het (landelijke) beleid, en de pretenties en de ambities van het hele ondersteuningssysteem bereiken de cliënt via de dyades van cliënten en groepsleiders (Hation, Emerson, Rivers, Mason, Mason, Swarbrick, Kiernan, Reeves \& Albor, 1999). 
Het cruciale belang van de dyade als interface tussen individu en omgeving is bijvoorbeeld aangetoond in het Milwaukee project dat de invloed van (zeer) nadelige en kansarme omgevingen bestudeerde op de cognitieve ontwikkeling van jonge kinderen met verstandelijke beperkingen: de moeder of primaire verzorger blijk cen belangrijke mediërende rol te spelen bij de invloed van de omgeving op de (cognitieve) ontwikkeling van kinderen met verstandelijke beperkingen (Garber, 1988). Zo bleek het effect van extreem ongunstige sociale omgevingscondities (armoede) op de ontwikkeling van het kind sterk afhankelijk van de kwaliteiten wan de primaire verzorger en zijn of hat relatie met het jonge kind. Ook in professionele zorgsinuaties (met name voor het bereiken wan positieve hechting) is het cruciale belang van dyades tussen groepsleiders en kinderen vastgesteld (Goossens \& IJzendoorn, 1990\%.

\subsubsection{Voorwaarden voor gunstige interacties}

Op basis van resultaten van empirische toetsing van Bronfenbrenner's theorie kunnen voorwaarden worden geformuleerd waatonder dyades binnen microsystemen gunstig zijn voor de ontwikkeling en het functioneren van mensen. Tocgepast op de situatie van bewoners van een woongroep binnen een residentiële instelling leidt dat tot de volgende condities. Tenzij anders aangegeven zijn deze geformuleerd op basis van Bronfenbrenner (1974, 1986 en 1999).

1. Een duurzame emotionele band tussen bewoner en groepsleider werkt faciliterend voor de ontwikkeling en het functioneten van de bewoner.

2. Positieve en ondersteuncnde relaties van groepsleiders met derden (binnen of buiten de organisatie) hebben een posirief effect op de dyade groepsleider - bewoner. Deze stelling komi overeen met de sociale steun die groepsleiders ontvangen van collega's, vrienden, hun familie, en van anderen in de organisatie. Hierdoor wordt de groepsleider effectiever in het ondersteunen van de bewoner (Cohen \& Wills, 1985; Tausig, 1992).

3. Bewoners funcrioneren binnen meerdere microsystemen, bijvoorbeeld hun woongroep en hun familie. Een ondersteunende verbinding tussen twee microsystemen bevordert de ontwikkeling en het functioneren birnen elk van de microsystemen. Een verbinding is ondersteunend wanneer er sprake is van wederzijds vertrouwen, een gezamenlijke positieve oriëntatie op het welzijn van de bewoner en consensus over de doelen van de hulpverlening. De ondersteunende verbinding kan direct of indirect zijn. Directe verbindingen betreffen directe contacten tussen groepsleiders en voor de bewoner belangrijke familieleden. Indirecte verbindingen betreffen contacten tussen groepsleiders en familie via een derde relevante persoon (bijvootbeeld, een leidinggevende of maatschappelijk werker in de organisatie).

4. Tevredenheid over de onderlinge communicatie tussen leden van verschillende microsystemen (groepsleiders en familieleden wan een bewoner) facilitect het functioneren van de persoon binnen deze systemen. Naarmate deze 
communicatie meer in persoonlige contacten plats vindt, is dit meer bevorderlik voor het functioneren van de bewonet.

5. Directe en effectieve contacten van groepsleiders (uit het microsysteem) met relewante 'machtscentra' (exosystemen waat beslissingen over bewonets, groepsleiders en budgetten wan de woongroep worden genomen) bevordetan het functioneren wan bewonets van de betreffende woongrop. Het gaat hietbij dus on positieve contacten tussen groepsleiders, hun leidinggevenden en medewerkers van verschillende ondersteunende diensten.

6. De kans op vooruitgang in functioneren neemt toe wannee bewoners ook andere settings betreden dan de eigen woongroep. Een verhuizing naar cen andere woongroep biedt in dit verband kansen op voonutgang, mits de persoon voldoende en juiste ondersteuning krijgt om zijn vardigheden en mogelijkheden verder te ontwikkelen.

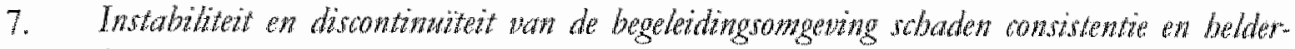
beid wan do sociale rallen binnen bet morosstem. Stabiliteit heeft te maken met voorspelbaatheid en de mogelikheid voor het individu een zekere controle uit te oefenen op de omgeving ("wat het individu doet, doet ettoe) en vermindert stress. Stabiliteit is niet alleen een objectief kenmerk van de omgeving maxir ook een subjectieve beleving.

Daanaast staat stabiliteit niet los van de kwaliteit van de omgeving. Het is onjuist te stellen dat grotere stabiliteit zondermeer beter is. Bijvoorbeeld: vertrek van disfunctionerende groepsleiders kan de kwaliteit van het microsysteem verbeteren en een verhuizing naar een woongroep met nueer kansen en uitdagingen betekent weliswaar discontinuiteit maar biedt positieve kansen voor ontwikkeling en functioneren (Wachs, 1999, p. 370-372; Luckasson et al., 1992, p. 25; Schalock \& Kiernan, 1990).

In het kader wan ons onderzoek naar personeelswisselingen in woongroepen leiden deze bevindingen uit de sociale ecologie tot een antal richtinggevende stellingen voot ons onderzoek.

Personeelswisselingen kunnen worden opgevat als verstoringen vari de voor effectieve begeleiding noodzakelijke stabiliteit in het microsysteem van de woongroep (condities 1 en 7 ).

Het functioneren van mensen met verstandelijke beperkingen in cen woongroep kan niet los wotden gezien van de context van hur familie en andere relevante microsystemen. Vetstoringen van de ielaties tussen microsystemen leiden immers tot effecten in de microsystemen warbinnen de persoon zich bevindt. Personeelswisselingen kunnen worden gezien als storende factor in de relatie tussen twee belangrijke mictosystemen (woongroep en familie), in het bijzonder in de opbouw en het behoud wan het vettrouwen van de familie in de (kwaliteit van de) hulpverlening in het algemeen en in het team van groepsleiders in het bijzonder (condities 2,3 en 4 ). 
De woonomgeving van mensen met verstandelijke beperkingen in residentiele voorzieningen is tevens werkomgeving van de medewerkers. De wijze waarop groepsleiders hun functioneren binnen de organisatie ervaren is relevant voor de effectiviteit van hun begeleiding (condities 2 en 5). Personeelswisselingen verstoren de relaties tussen medewerkers en cliënten: dit wordt gereflecteerd in de tevredenheid van groepsleiders over hun contacten met het clientsysteem en over de effectiviteit van hun functioneren als team (condities 1 en 4 ).

In residentiële instellingen voor mensen mer verstandelijke beperkingen vinden de hierboven beschreven processen plaats binnen de context van een dienstenorganisatie. Het microsysteem van de woongroep maakt daarmee deel uit van een ruimer ecologisch systeem (in termen van Bronfenbrenner zowel meso- als exosystemen). Het naast-hogere systeem waarbinnen de woongroep is ingebed, is de instelling. Organisatiekenmerken van de instelling in het algemeen en kenmerken van de woongroep (structuren en processen) in het bijzonder zijn daarmee van belang voor de effectiviteit van de begeleiding.

In de volgende paragraaf zal worden beargumenteerd dat theorieèn over de interactie tussen frontihe medewerkers en cliënten in dienstenorganisaties congruent zijn met de sociaal-ecologische theorie van ontwikkeling en functioneren. Het doel van deze exercitie is een verband te leggen tussen enerzijds de meer inhoudelijk georiënteerde sociale ecologie (met betrekking tot ondersteuning van mensen met verstandelijke beperkingen) en anderzijds de organisatietheorie met betrekking tot marketing die relaties tussen de organisatie en haar cliëntgroepen beschrijft.

\subsection{Organisatietheorie}

In hoofdstuk 4 werd betoogd dat een residentiële instelling kan worden opgevat als cen dienstenorganisatie en dat marketingmodellen relevante kaders vormen voor het otganiseren en managen van deze instellingen. Voor de door het cliëntsysteen ervaren kwaliteit van begeleiding werd het cliënttevredenheid-model van Gröntoos gekozen en een aantal uit onderzoek bekende antecedenten van clientterredenheid werden geinventariseerd.

We zullen nu dieper ingaan op de het theoretische verband tussen cliënttevredenheid en deze antecedenten binnen de dienstenotganisatie.

\subsubsection{Functioneren van het dienstenteam}

De kwaliteit van de directe werkomgeving van medewerkers in dienstenorganisates wordt sterk bepaald door hun beleving van werktaken, van hun collega"s en van de bredere organisatie. In dienstenorganisaties ervaten medewerkers hun eigen vaardigheden en hun mogelijkheden (bevoegdheden) om resultaten met of voot de client te boeken als belangrijke voorwaarden voor het leveren van goede diensten 
en voot de tevredenheid van de cliënten. Het gevoel effectief bij te kunnen dragen tot tevredenheid van cliënten maakt een belangtijk deel uit van hun arbeidstewtedenheid (Heskett, Jones, Loveman, Sasser \& Schlesinger, 1994).

Binnen deze constatering zijn twee zaken wan belang. "Ten eerste, het bestaan van een verband tussen de tewredenheid van medewerkers en die van cliënten. In een dienstenorganisatie kunnen, volgens Heskett et al, beide als elkars spiegelbeeld worden gezien. Met name binnen dienstenorganisaties met een langdurige relatie tussen dienstverlener en cliënt zou er een sterk verband bestaan nussen arbeidssatisfactie van medewerkers en tevredenheid vat cliënten. Front-hine medewerkers moeten dan wel lang genoeg op hun positie blijven opdat afzonderlijke contacten met cliënten kumnen uitgroeien tot een relatie waarin zij elkaar sneller begrijpen en er minder misverstanden kunnen ontstaan over de behoeften van de cliënt en over waarden die voor beide partijen in hun transacties belangrijk zijn. Continuiteit en consistentie in cliëntcontacten zijn dus van groot belang voor het opbouwen en behouden van cliëntspecifieke kennis. Ten tweede, de arbeidssatisfactie van medewetkers heeft betrekking op meerdere aspecten zoals (1) arbeidsomstandigheden, (2) de manier waarop hun baan tegenoet komt aan hun persoonlijke behoeften (interne marketing), (3) hun relaties met collega's en (4) de mate warin zij het gevoel hebben te slagen in hun opdracht ten aanzien van de cliënten. De relaties met collega's verwijzen zowel naar hun relatie met collega's in hetzelfde team als naar hun ervaring van ondersteuning vanuit de back-office functies van de organisatie. Deze relaties zijn belangrijk omdat zij een bron zijn van sociale steun die zowel bijdraagt aan arbeidssatisfactie als aan de preventie van emotionele uitputting (Tummers, Janssen, Landeweerd \& Houkes, 2001). Frequente personeelswisselingen zijn niet bevorderlijk woor het geven van onderlinge sociale steun (Tummers, Van Merode \& Landeweerd, 2002).

Medewerkers die het gevoel hebben niet (voldoende) tegemoet te (kunnen) komen aan in hun ogen legitieme behoeften en vragen van de cliënt, ervaren minder arbeidssatisfactie, ook al zijn ze tevreden met hun arbeidsvoorwaarden, hun werkomstandigheden en hun collega's. Uit onderzock blijkt dat er cen verband bestaat tussen verloop van medewerkers en een lagere kwaliteit van dienstverlening en lagere klanttevreclenheid. (Heskett, Sasser \& Schlesinger, 1997; Schlesinger \& Heskett, 1991; Wetzels, 1998). Deze onderzoeken laten zien dar lage arbeidssatisfactie en hoog verloop beide een eigen negatief effect hebben op cliënttevredenheid. Wanneer aan verloop nog eens extra discontinuiteit in de vorm van personeelswisselingen in het woongroepteam wordt toegevoegd, mag worden aangenomen dat een hogere freguentic van personeelswisselingen - ook bij gelijk verloop op instellingsniveau - in de perceptie van cliënten van residentiële instellingen (bewoners en hun familie) leidt tot lagere tevredenheid met de kwaliteit van dienstverlening.

Hartline en Ferrell (1996) deden onderzoek naar de medewerkers-cliënt interface met betrekking tot klantevredenheid in dienstenorganisaties en stelden op basis hiervan een empirisch model op (tabel B6.1). Dit model bevat een aantal empirisch 
relevant gebleken factoren woor de effectiviteit van een dienstenteam, witgedrukt als doot cliënten ervaren kwaliteit van dienstverlening. In de context van ons onderzoek leidt hun model tot de volgende beweringen:

1. Er is cen positic verband tussen de arbeidssatisfactic van front-lime medewerkers en de door cliënten waargenomen kwaliteit van dienstverlening.

2. Er is een positief verband tussen het vertrouwen van front-line medewerkers in eigen doelmatigheid en de door cliënten waargenomen kwaliteit van dienstwerlening.

3. Er bestaat een positief verband tussen ervaren rolduidelijkheid bij front-line medewerkers en arbeidssatisfactie.

4. Er bestaat een positief verband tussen ervaren rolduidelijkheid bij front-lime medewerkers en vertrouwen in eigen doelmatigheid.

5. Er bestaat een negatief verband tussen de mate waarin de organisatie eigen initiatief en zelfstandigheid (empowerment) van front-line medewerkers bevordert en de door hen ervaren rolduidelijkheid (grotere mate van zelfstandigheid leidt tot meer rolconflicten en claarmee tot lagere rolduidelijkheid).

Ook uit onderzoek van Werzels (1998) blijkt dat er in een dienstenorganisatie een relatie bestaat tussen rolduidelijkheid en arbeidssatisfactie: onduidelijkheid over te verwullen taken leidt tot minder arbeidssatisfactie (zie punt 3 hierboven). Empowerment heeft volgens de studie van Wetzels echter een direct en positief verband met arbeidssatisfactie. Empowerment en rolduidelijkheid zijn eveneens gerelateerd: grotere autonomie voor het nemen van beslissingen gaat gepaard met hogere rolduidelijkheid (dit is duidelijk een andere bevinding dan bij Hartline en Ferrell). De relatie tussen rolduidelijkheid en cle kwaliteit van het werk van groepsleiders is ook in de resiclentiële zorg voor mensen met verstandelijke beperkingen aangetoond (Blumenthal, Lavender \& Hewson, 1998).

In het kader wan ons onderzoek naat personeelswisselingen in woongroepen leiden deze bovenstaande otganisatietheotetische bevindingen met betrekking to de effectiviteit van het teamfunctioneren van fromt-line medewerkers in dienstenotganisaties tot een aantal tichtinggevende stellingen:

- Personeelswisselingen kunnen worden opgevat als verstoringen van de arbeidssatisfactie en de rolduidelijkheid van groepsleiders (Hesket en Schlesinger, 1991; Wetzels, 1998).

Er bestaat een relatie tussen enerzijds arbeidssatisfactie, rolduidelijkheid, het vertrouwen in eigen doelmatigheid en de ervaren empowerment van groepsleiders en anderzijds de door familie waargenomen kwaliteit van begeleiding (Hartline en Ferrell's conclusies 1,2,3,4 en 5).

Personeelswisselingen gaan gepaard met een lagere door familie van cliënten ervaren kwaliteit van begeleiding (afgeleid uit de twee vorige beweringen). 


\subsubsection{Het meten van cliënttevredenheid}

In paragraaf 4.1.5 werd de relatie tussen de begrippen 'cliënttevredenheid' en 'kwaliteit van zorg' besproken. Hoewel het hier afzonderlijke begrippen betreft zijn ze in de praktijk van dienstwerlening naw met elkaar verbonden (De Vries \& Goud, 2003). Het gaat in beide gevallen om de afweging tussen ervatingen en behoeften of verwachtingen; over de mate waarin naar het oordeel van de client, aan zijn verwachtingen of vraag wordt voldaan. Het onderzoek thaar cliènttevredenheid kent echter een aantal zowel conceptuele als methodologische problemen. Alvorens dit begrip voor ons onderzoek te operationaliseren (hoofdstuk 7) wordt in deze paragraaf hieraan aandacht besteed.

\section{Problemen bij het meren van cliënttevredenheid}

Clënttevredenheid wordt meestal opgevat als een samenspel van cognitieve afwegingen en emotionele belevingen met betrekking tor de ervating van een product of een dienst als geheel, of van een deelaspect daarvan (Harteloh, Sprij \& Casparie, 1992). Steeds vaker worden cliënttevredenheidsmetingen als indicator van kwaliteit vanuit het gebruikersperspectief toegepast. Kwaliteitsmodellen zoals het INK en het MKG woorzien hier ook nadrukkelijk in (INK, 2001a, 2001b; Vereniging Gehandicaptenzorg Nederland, 2000).

Cliënttevredenheid over de kwaliteit van een dienst wordt algemeen opgevat binnen een discrepantiemodel. Dit model stelt dat 'tevredenheid' de uitkomst is van een afweging tussen behoeften en ervaringen. Behoeften worden uitgedrukt in de verwachtingen die men heeft van de dienstverlening. Cliënttevredenheid is afhankelijk van het verschil tussen de beleving (b) en de a-ptioni verwachting (v) die de cliênt wan de waarde van de dienst had (Harteloh, Sprij \& Casparie, 1992):

cliënttevtedenheid $=\underline{(b)-(v)}$

Het besproken model van Grönroos (paragraaf 4.1 .5 en figuur 4.2) is duidelijk een vertegenwoordiger van dit discrepantiemodel. Aan het discrepantiemodel liggen een aantal verondetstellingen ten grondslag (Williams, 1994). Zo gaat het Grönroos-model er van uit dat mensen die cen dienstenrelatie aangaan dit doen met bepaalde a-priori verwachtingen en dat zij de bereidheid en het vermogen bezitren om de kwaliteit van deze relatie te evalueten. Impliciet wordt binnen dit model aangenomen dat verwachtingen en ervaring onafhankelijk van elkaar bestaan. Verder wordt aangenomen dat cliënten autonome en kritische consumenten zijn van de diensten van de aanbieder en dat 'tevtedenheid' een onafhankelijk fenomeen is en niet een artefact van de gebruikte vragenlijsten. Deze kritische beschouwingen van Williams zijn voldoende reden om het discrepantiemodel nader te onderzocken. 
Een eerste moeiil heid van het discrepantiemodel is de conceptualisering van verwachte dienstretlening. Verwachtingen kumen worden gezien als (1) ideale verwachtingen, gebaseerd op een idealistisch beeld van de dienst; (2) realistische of pragmatische verwachtingen, gebaseerd op eigen evaringen of erwaringen van anderen; (3) normatieve verwachtingen, als opvattingen over wat de dienst zou moeten inhouden of in stat zou moeten zijn on te leveren of waar de client recht op heeft; (4) diffuse verwachtingen, wanneer de gebruiker geen verwachtingen koestert of deze niet kan of wil formuleren, hetzij uit vrees (de dienst te verliezen) of onder invoed van sociale dnuk. Daarenboven worden de verwachtingen van een client beinvloed door zeer uiteenlopende factoren waatonder informatie, stemmingen en emoties, de rol van de cliënt, sociale normen en belangen (Mckinley, Stevenson, Adams \& Scott, 2002; Pieters, 1995; Thompson \& Suñol, 1995 ).

Een tweede moeilijhet van het discrepantiemodel is het niet lineaire verband tussen verwachtingen en ervatingen. Wit onderzoek blijkt dat cliënten de component 'verwachtingen' over het algemeen zwaarder te laten wegen in hun uiteindelijke tevtedenheidoordelen. Hierdoor treedt een assimilatie effect op: de client stelt zijn ervaringen bij in de tichting van zijn verwachtingen. Zo ontstat er een zone van tolerantie warbinnen verschillen tussen de uiteindelik geute revredenheid klein zijn in verhouding tot de (werkelijke) verschillen tussen enerzijds de verwachte en anderzijds de ervaren kwaliteit of de objectieve kwaliteitskenmerken wan de geboden dienst. Men kan dus in principe tevredenheid uiten (in een vragenlijst) terwijl een clicnst objectief gezien - naar professionele maatstaven, bijwoorbeeld 'slecht' is of men feitelijk (ook) negatieve ervaringen met de dienst heeft. Dit verschijnsel doet zich juist omgekeerd voor bij de extreme posities. Wanneer de verwachtingen aanmerkelijk lager waren dan de ervaren kwaliteit, dan wordt tevredenheid onevenredig hoog geuit. Indien de verwachtingen aanmerkelijk hoger waren dan de feitelitke ervaring, dan volgt een veel lagere geurce tevredenheid dan op grond wan de feitelijke ervaringen of objectieve kenmerken van de geboden dicnst kan worden verklaard. De teleurstelling wordt dan breed uitgemeten en gegchetrasectid. Fit ontstat op dat moment een contrast-effect Thompson \& Suñol, 1995; Baron-Epel, Dushenat \& Friedman, 2001).

Onderzock in de residentiele zorg woor mensen met verstandelijke beperkingen illustrect een derde mocilijkheid die met de vorige twee samenhangt: de familie van clienten blijkt over het algemeen eetder genegen "tevredenheid" te melden. Daarbij spelen de volgende tedenen een rol: (1) begrip tonen woor de moeilijke situatie wan groepsleiders; (2) de vrees 'ondankbaar', 'ontevreden' of 'onbeleefd' te worden gevonden; (3) de wetenschap dat het moeilik is on een alternatief te vinden voor het verblijf in de betreffende instelling vanwege lange wachtijsten en tijdrovende procedures; (4) het gevoel dat bij voortduing ondanks vragen en signaleren (toch) geen verandeting ontstat: men legt zich bij de situatie neer; (5) de vrees dat uitingen van ontertedenheid een negatief effect zullen hebben op de zorg voor het familiclid; (6) het feit dat cen vragenlijst over kwaliteit wordt verstrekt werkt als sig- 
naal dat de organisatie hieraan aandacht besteedt, wardoor het oordeel positiever wordt: het "Hawthorne effect" (Kars \& Janssen, 1992). Olson on Schober verklaren het rapporteren van meer tevredenheid (méér dan op grond van gelijktijdig elders geuite kritiek of op grond van de objectieve situatie zou worden verwacht) met een combinatie van de cognitieve dissonantietheorie (Festinger) en de theorie van angeleetde hulpeloosheid (Seligman). De uitkomst van een tevredenheidsmeting kan op die manier worden beschouwd als de uitkomst van een adaptatieproces waatin beide fenomenen een rol spelen (Olson \& Schober, 1993). Het adaptatieptoces is gericht op het zoeken van een door de persoon ervaren harnonische verhouding met de omgeving binnen het spanningsveld van enerzijds individuele verwachtingen en anderzijds beperkingen van de omgeving (Albrecht \& De Vlieger, 1999).

Een vierde en meer technische moeilijkheid met vragenlijstonderzoek naar tevtedenheid is de negatieve scheefheid van de distributie van uitslagen: het gemiddelde ligt duidelijk rechts van de mediaan. Dat reflecteert het verschijnsel dat de meeste respondenten een positief tevtedenheidoordeel geven over de kwaliteit van zorg. De frequentie van 'tevreden' cliènten ligt meestal boven $70 \%$ en de gemiddelde score van tevredenheidoordelen ligt overwegend rond 75 procent (Hall \& Dornan, 1988; Kars \& Janssen, 1992; Lebow, 1984; Parlak, Lako \& Van den Hoogen, 2002; Wetzels, 1998). Met name in correlatieonderzoek kan dit de gevonden waarden drukken; verbanden tussen variabelen kunnen in werkelijkheid groter zijn dan de gevonden cortelatiecoëfficiënten laten zien.

Sommige auteurs suggeteren dat het meten van 'ontevredenheid' een relevant alternatief kan zijn (Kars \& Janssen, 1992). In ieder geval zijn oordelen van ontevredenheid relevante signalen, omdat daarbij de genoemde invloeden al "getrot seerd' werden. Zo blijkt ontevredenheid een goede predictor van de geneigdheid on van zorgaanbieder te verandeten (Baron-Epel, Dushenat \& Friedman, 2001).

\section{Methodologische implicaties}

Een veel gebrukt instrument voor het meten van door cliënten waargenomen kwaliteit van dienstverlening (ofwel: cliënttevredenheid) is SERVQUAL. Hiemee worden ootspronkelijk tien, en op dit moment vijf algemene dimensies van cen dienst gemeren. Her betreft: betrouwbaarheid, responsiviteit, zotgzaamheid, emparhie of inleven in de klant en tastbaarheden van de dienst (De Vries, Van Helsdingen \& Kasper, 2001; Zeithaml \& Bitner, 2003). Deze dimensies worden geoperationaliseerd in een aantal items. Aan de respondenten wordt cerst gevraagd hun oordeel te geven over de belangrijkheid van elke dimensie. Vervolgens wordt gevrangd concrete items te scoren aan de hand van de met de dienst opgedane crvaringen. Uit de combinaties van scores wordt het kwaliteitsoordeel van de cliënt berekend. 


$$
Q=E I_{i=1}\left(P_{i}-E_{i}\right)
$$

Waarin: $Q=$ waargenomen kwaliteit van de dienst

$I_{i}=$ Belang van een dimensie

$P_{i}=$ Ervaren niveau van dienstverlening in bepaalde dimensie

$\mathrm{E}_{\mathrm{i}}=$ Verwachte niveau van dienstverlening in bepaalde dimensie

$\mathrm{i}=$ Aantal dimensies van kwaliteit.

Ervaringen met dit instrument leidden tot verschillende kritiekpunten. De belangrijlkste zijn:

- De dimensies van een dienst blijken nogal sectorspecifiek en minder algemeen dan eerst werd aangenomen (De Vries, Van Helsdingen \& Kasper, 2001). Dit zou er toe leiden dat in elke situatie een nieuwe operationalisering wan de SERVQUAL ontwikkeld zou moeten worden.

- Zoals hierboven besproken is het begrip 'verwachting' niet eenduidig mar multi-interpretabel en ambigu. In een vragenlijstsituatie is onduidelijk welk verwachtingspattoon de cliënt hanteert (Pieters, 1995).

Verwachtingen en ervaringen van dienstverlening zijn niet onaflaankelijk van elkaat. Er treden de eerder genoemde assimilatie- en contrast-effecten op waarbij de verwachtingen van cliënten hun oordeel over de ervaren dienst positief beinvloeden (Hall \& Dornan, 1988; Thompson \& Suñol, 1995; Pieters, 1995).

- Het meten van verschillen levert problemen op: verschilscores zijn minder betrouwbaar dan de betrouwbaarheid van de afzonderlijke schalen waarop zij zijn gebaseerd (Wetzels, 1998).

SERVQUAL levert negatief scheve distributies op. Dit kan leiden tot onderschatting van de rellatie tussen kwaliteitsoordelen en andere variabelen (Wetzels, 1998).

Voor deze tekorkomingen werden oplossingen bedacht waarvan de QUOTE instrumenten van Sixma et al. voor de praktijk van kwaliteitsverbetering in zorgorgantsaties zeer origineel zijn. De QUOTE instrumenten zijn vragenlijsten die de door cliènten ervaren kwaliteit combineren met het belang dat cliënten aan elk betreffend aspect hechten. Dit laatste is een conceptualisering van "verwachte kwaliteit'. Het resultat van deze combinatie is een 'impactscore' (Sixma, Kerssens, Van Campen \& Peters, 1998; Sixma, Van Campen, Kerssens \& Peters, 1998). 
De QUOTE vragenlijsten zijn gebaseerd op de formule:

$$
Q_{i j}=P_{i j} \times I_{i j}
$$

Waarin: $\quad Q_{i f}=$ het oordeel over een bepaald aspect (j) door een individu (i) $P_{i j}=$ de Performance score (ervaren kwaliteit) van een individu (i) met betrekking tot aspect (1) $\mathrm{I}_{\mathrm{i}}=$ de Importance score (belang) van het individu (i) voor aspect (j).

In de praktijk geeft de respondent per item (een indicator van kwaliteit) een I score van 0 (niet belangrijk), 3 (eigenlijk wel van belang), 6 (belangrijk) of 10 (van het allergrootste belang). Op basis van de scores van alle respondenten, wordt voor elk item de gemiddelde I-score berekend.

De P score komt tot stand door dezelfde items te laten scoren voor ervaren kwaliteit. Daarbij worden de negarieve ervaringen uiteindelijk weerhouden (bijvoorbeeld de categorieën die duiden op 'niet tevreden'). De P uitslag voor een bepaald item bestaat uit het percentage negatief scorende respondenten. Het product van I en P geeft per item een impactscore. Daarmee kan een hiërarchie worden opgesteld van items volgens hun impactscore.

Het voordeel is dat op grond van de uitkomsten per organisatie of per organisatieonderdeel een hiërarchie van de items kan worden opgesteld; daarmee kunnen prioriteiten voor kwaliteitswerbetering worden weergegeven. De Quote techniek is daarmee zeer geschikt voor praktische toepassing in de context van kwaliteitsmanagement van zorgorganisaties (Buntinx, 2003b). Het nadeel van de QUOTE methodiek is dat de impactscores van verschillende instellingen bezwarlijk bij elkaar kunnen worden opgeteld omdat de gewichten binnen de context van een bepaalde organisatie worden verkregen. Daarenboven resulteert de QUOTE methodiek in specifieke waarderingen van indicatoren waarvan de impacrscores niet met elkaar kunnen worden opgeteld. Dat makt de QUOTE methode minder geschikt voor gebruik in wetenschappelijk onderzoek. Omdat impactscores producten zijn van twee afzonderlijke scores, kan een uiteindelijke watede langs verschillende weg worden bereikt. Bij het sommeren en middelen van impactscores gaat derhalve veel betekenis verloren.

\section{Ervaren kwaliteit van begeleiding in ons onderzoek}

In overeenstemming met de opvattingen van Grönroos worden in ons onderzoek twee dimensies van ervaren kwaliteit onderscheiden: de technische en de functionele kwaliteit. De technische kwaliteit heeft betrekking op inhoudelijke aspecten van de dienstwerlening; de functionele kwaliteit heeft betrekking op de interactieaspecten en wijze warap de dienst wordt verleend. De door De Vries, Van Helsdingen en Kasper (2001) toegevoegde relationele dimensie nemen wii in ons onderzoek niet mee. Hiervoor hebben we twee argumenten. Ten eerste heeft de func tionele kwaliteit al in sterke mate betrekking op de relationele aspecten van dienst- 
verlening; in het bijzonder op de bejegening die de familie zelf ervart en waarneent in de riching van hun familielid, en op het vertrouwen dat men als famile hect in de groepsteiding. Aan deze aspecten wordt ruim aandacht besteed in de te gebruiken CPSQ-schal (hoofdstuk 7). Ten tweede heeft de telationele kwalitei zoals bedoeld doot De Vries, Van Helsdingen en Kasper betrekking op de repuatie on de sociale positie van verschillende medewetkers. In ons onderzoek - op teamiveau - word geen onderscheid gemaakt naar specifieke functies van de onderscheiden groepsleiders. Aan de famille wordt ook niet gevragd nar tevredenheid in relatie tot specifieke functies van groepsleiders. Een afzonderlike analyse van de door De Vries et al. genoemde relationele aspecten is dan ook niet mogelijk.

Door de keuze voot de CPSQ schaal wotd nadrukkelik andacht besteed aan de in onze situade meest belangrijke SERVQUAL dimensies. Uit onderzoek blikt dat naamate de ontastbaarheden van een dienst toeneemt (materiele componenten spelen een kleinere rol), de verwachtingen van cliènten met betrekking tot de aspecten betrouwbarheid, empathie, responsiviteit en zekerheid toenemen. Ook het gewicht van deze aspecten in het uiteindelijke kwaliteitsoordeel neemt dan toe (Bebko, 2000). Om deze redenen wordt woorkeur gegeven aan het gebruik van het begrip "relationele kwaliteit". In deze studie zal, wanneer verwezen wordt naar Grönroos' originele begrip 'functionele kwalitett" de term "relationele hwaltet" worden gebruikt.

Op grond wan argumenten die genoemd werden in paragraf 4.1 .3 wordt in deze studie naar personeelswisselingen gekozen voor het meten van de cliënttevredenheid bij de familie of anderszins meest directe contactpersonen van de bewoners.

In het licht van de besproken problemen rond het meten van clienttevredenheid met kwaliteit van zorg volgen wij Wetzels in zijn anabeveling een directe meting van ervaten kwaliteit te gebruiken en geen verschilscores of belangrijkheidscores toe te passen. Op grond van zijn empirisch onderzoek is deze methode verantwoord gebleken; het effect van verwachte op ervaren kwaliteit wordt voldoende mecgewogen. On de spreiding van uitslagen te bevorderen en de scheefheid te beperken zal een zevenpuntenschaal worden gebruikt. Het begrip 'tevredenheid' zal nict in de vragenlijst worden gebruikt mat er zal worden gevraagd in hoeverre de respondent hot eens is met beweringen die aspecten van kwaliteit vertegenwoordigen.

\subsection{De onderzoeksvragen binnen de theoretische context}

Het doel van het vootgenomen empirisch onderzoek is inzicht te verwerven in het verschijnsel personeelswisselingen in woongroeptrams van tesidentiele instellingen voor mensen met verstandelijke beperkingen. Daabij wordt de aandacht gericht op de relatie tussen personeelswisselingen ( $P W$ ) en organisatiekenmetken $(A$, kenmerken van teamfunctioneren (B), en door familie van bewoners ervaren kwaliteit van begeleiding (C). 
Op grond van de in hoofdstuk 5 geselecteerde empirische correlaten van 'personeelswisselingen', en op grond van de in dit hoofdstuk besproken ecologische theorie en het model van Hartline en Ferrell, worden de onderzoekswragen nu definitief geformuleerd. Hierbij laten we ons leiden door de eerder geformuleerde richtinggevende stellingen (paragraaf 6.2 .2 en 6.3.1) en de conclusies over cliënttevredenheid (paragraf 6.3). Rekening houdend met de drie type-maten als tepresentatie van verschillende modaliteiten van personeelswisselingen (paragraaf 3.2.4), leidt dit tot het theoretische model voor empitisch onderzoek zoals getoond in figuur 6.6 .

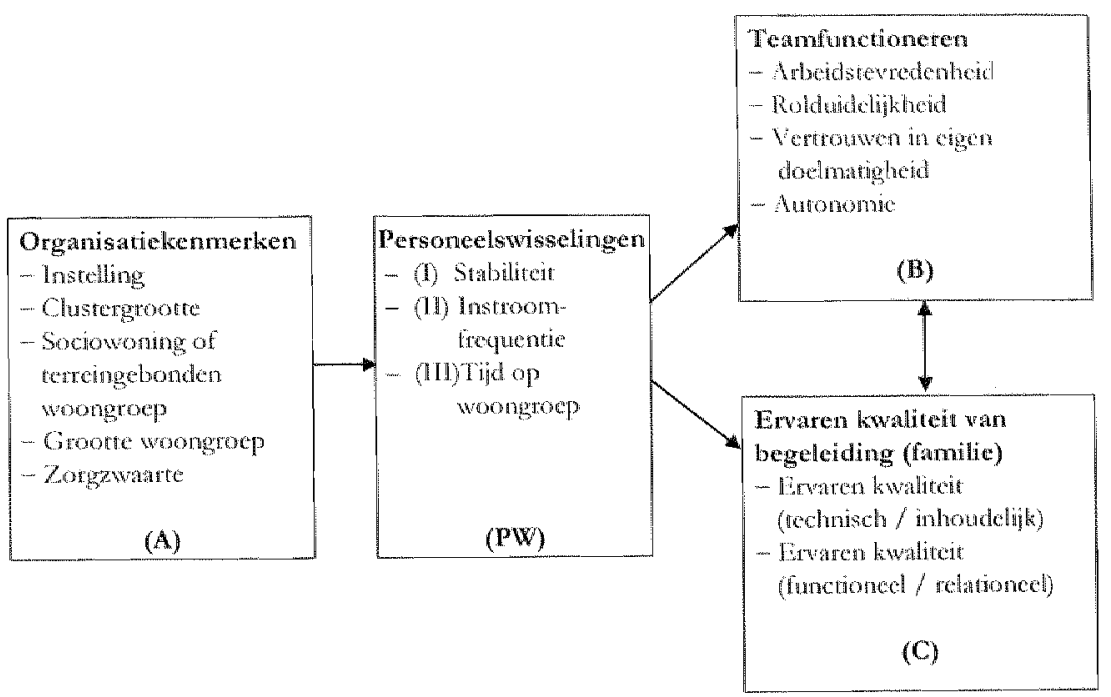

Figuur 6.6 Theoretisch kader voor het empirisch onderzoek naar personeelswisselingen

De probleemstelling en onderzoeksvragen luiden:

Probleemstelling: wat is de samenhang tussen personeelswisselingen, organisatickenmerken, effectiviteit van het teamfunctioneren, en de door het clientsystcom ervaren kwaliteit van begeleiding?

\section{Onderzoeksvragen:}

1. Is er een verband tussen organisatiekenmerken en personeelswisselingen?

We vragen ons af of de omvang van personeelswisselingen samenhangt met (1) de instelling als zodanig (de omvang van PW verschilt tussen instellingen) en verder met de volgende woongroepkenmerken: (2) de grootte van het cluster waaryan de woongroep deel uitmaakt; (3) sociowoning of woongroep op instellingsterrein; (4) grootte van de woongroep en (5) zorgzwaarte. 
2. Is er een werhand tussen personeelswisselingen en teameffectiviteit?

We vragen ons af of er een verband is tussen personeelswisselingen en de volgende cffectiviteitskenmerken van het teamfunctioneren: (1) de arbeidssatisfactie, (2) de ervaten rolduidelijkheid van groepsleiders, (3) het vertrouwen in eigen doelmatigheid, en (4) de door groepsleiders ervaren ruimte voor eigen initiatief (autonomie of empowerment).

3. Is er een terband tussen personeelswisselingen en door faxtilite eryaren kewathitets wan begeleiding?

We vragen ons af of er een verband is tussen personeelswisselingen en de door familie ervaren kwaliteit van de begeleiding, onderscheiden in de 'technische' of inhoudelijke kwaliteit en de 'functionele' of relationele kwaliteit.

4. Is er een verband tussen de teaneffectiviteat en de door familie ervaren kewaliteit tan begeleiding?

Is er een verband tussen enerzijds 'arbeidssatisfactie', 'rolduidelijkheid', 'vertrouwen in eigen doelmatigheid', en 'ervaten autonomie' van groepsleiders en anderzijds, door familie ervaren inhoudelijke en relationele kwaliteit van begeleiding?

5. Wy lke rol spelen personeelswisselingen bij bet eventuele verband tussen teaweffectiviteit en de door bet diëntsysteem envaren kwaliteit wan begeleiding?

Zijn personeelswisselingen een moderator van het verband tussen effectiviteitaspecten van teamfunctioneren en door famillie ervaren inhoudelijke en relationele kwaliteit van begeleiding?

6. Kan een model worden opgesteld van de saknenhang twssen (1) wrongropkenmerken. (2) personeelswisselingen en (3) teameffectiviteit als voorspellers van de door familie crvaren kinatiteit van begreleiding? 
Opzet van het onderzoek 

Paragraaf 7.1 van dit hoofdstuk begint met het doel van deze studie en operationaliseert de onderzoekswagen in deelvragen op basis van de uitkomsten wan de literatuurverkenningen (hoofdstukken 2, 3, 4 en 5 ) en binnen het theoretisch kader (hoofdstuk 6). In paragraaf 7.2 wordt de onderzocksgroep van de empirische studie beschreven. Vervolgens wordt in paragraf 7.3 de onderzoeksmethode besproken, gevolgd door de operationaliseting van de deelvragen en de beschripring van de gebruikte instrumenten in paragraaf 7.4. In paragraat 7.5 wordt de procedure van het onderzoek en in paragraaf 7.6 de werkwijze bij de data analyse beschreven. Tot slot worden in paragraf 7.7 de geoperationaliseerde onderzoeksvragen en deelvragen geformuleerd.

\subsection{Doelstelling en onderzoekswragen}

Het doel van deze studie is: inzicht verwerven in het verschijnsel personeelswisselingen in woongroepteams van tesidentiële instellingen voor mensen met verstandelijke beperkingen. De gekozen benadering is gesitueerd op het niveau van de woongroepen: dit zijn de interfaces tussen organisatie en cliëntsysteem waar de begeleiding daadwetkelijk plaatsvindt. Personeelswisselingen worden gezien als cen organisatie- en managementprobleem dat samenhangt met woongroepkenmerken en effecten heeft op het teamfunctioneren en op de door familie van bewoners ervaren kwaliteit van begeleiding. Met de bevindingen uit de literatuurverkenningen en met het geconstrueerde theoretisch kader, kunnen tru de probleemstelling en de zes onderzoeksvragen met bijhotende deelvragen worden geformuleerd. Deze luiden:

Probleemstelling: wat is de samenhang tussen personeelswisselingen, organisatickenmerken, effectiviteit van het teamfunctioneren, en de door het cliëntsysteem ervaren kwaliteit van begeleiding?

Onderzocksvragen en deelviagen:

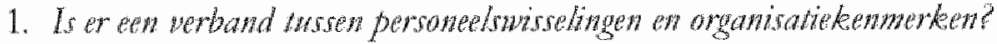

1.1. Is er een verband tussen personeelswisselingen en de factor "instelling?

1.2. Is er een verband tussen personeelswisselingen en de omvang van het cluster waarvan woongroepen deel uimaken?

1.3. Is er een verband tussen personeelswisselingen en de situering van woongroepen op of buiten het instellingsterrein?

1.4. Is er een verband tussen personeelswisselingen en de grootte van woongroepen?

1.5. Is er cen verband tussen personcelswisselingen en de zorgzwaarte van woongroepen?

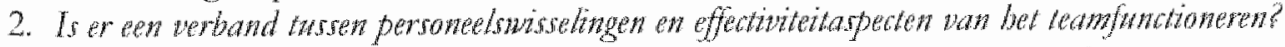

2.1. Is ex cen verband tussen personeelswisselingen en door teamleden ervaren arbeidssatisfactie?

2.2. Is er een verband tussen personeelswisselingen en door teamleden ervaten rolduidelijkheid? 
2.3. Is er een verband tussen personeelswisselingen en het door teamleden erwaren vertrowwen in eigen doelmatigheid?

2.4. Is er eev verband tussen personeelswisselingen en door teamleden ervaren autonomie?

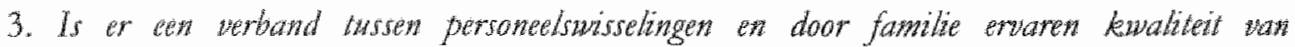
begeleding?

3.1. Is ex een verband tussen personeelswisselingen en door familie van bewoners erwanen inhoudelijke kwaliteit van zorg?

3.2. Is er cen verband tussen personeelswisselingen en door familie van bewoners ervaren relationele kwaliteit van zotg?

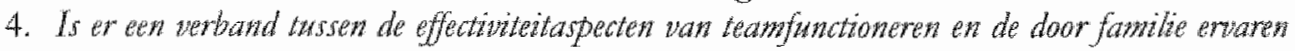
kwalkit wan begeleiding?

4.1. Is er een verband tussen de door teamleden ervaren arbeidssatisfactie en de door familic crvaren inhoudelijke en relationele kwaliteit van zorg?

4.2. Is er een verband tussen de door teamleden ervaren rolduidelijkheid en de door familie ervaren inhoudelijke en relationele kwaliteit van zorg?

4.3. Is er een verband tussen de doot teamleden erwaren vertrouwen in eigen doelmatigheid en de door familie ervaren inhoudelijke en relationele kwaliteit van zotg?

4.4. Is er een verband tussen de door teamleden ervaren autonomie en de door familie ervaren inhoudelijke en relationele kwaliteit van zorg?

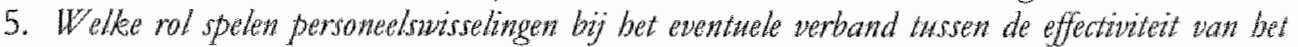
teamfwntioneren en de door fanilie waw bewoners erwaren kwatiteit wan begeleiding?

5.1. Is de factot personeelswisselingen een moderatot van het verband tussen de effectiviteitaspecten van het teamfunctioneren en de door familie van bewoners ervaten inhoudelijke kwaliteit?

5.2. Is de factor personeelswisselingen een moderator van het verband tussen de effectiviteitaspecten van het teamfunctioneren en de door familie vard bewoners ervaren relationele kwaliteit?

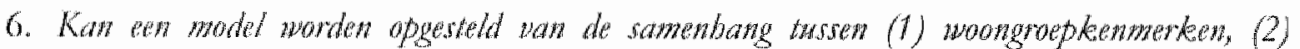

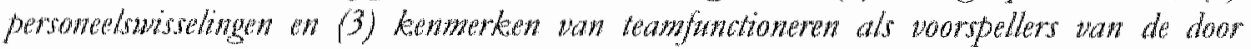
famile anawn kwalite wan begeleiding?

\subsection{Onderzoeksgroep}

Het empirisch onderzock werd uitgevoerd in vijf algemene instellingen voor verstandelijk gehandicapten. De populaties van deze instellingen zijn wat betreft niveau van functioneren en leeftijd representatief voor de totale Nederlandse populatie van algemene instellingen (tabel 7.1). De instellingen $A, B$ en $C$ waten berokken bij eerder onderzoek naar personeelswisselingen (Buntinx, 1994; 2001; 2002); zij werden in de onderzoeksgroep opgenomen ondat daamee referentiemateriaal beschikbaar was voor vergelijking en voor ondersteuning van de interpretatie van resultaten. Bij de keuze van de overige instellingen werd rekening gehouden met een zekere spreiding van organisatiekenmerken. Zo bevindt de organisatiestructuur 
van de instellingen $A, B$, en $C$ zich in een overgangsfase tussen traditionele functionele organisatie ("professionele bureaucratie") en een meer gedivisioneerde en klantgetichte organisatie. De nieuwe situatie is daarbij nog niet getealiseerd en benoemingen van het nieuwe middenmanagement zijn nog niet geëffectueerd, maar de procedures daartoe zijn wel in gang gezet. Dit gaat gepaard met onzekerheid en relatief meer dan gebruikelijk verloop onder groepsleiders en leidinggevenden (Buntinx, 2002). De structuur van instelling $\mathrm{D}$ kan worden aangemerkt als een traditionele functionele organisatie. Veranderingen zijn well voorgenomen maar bevinden zich nog in de fase van voorbereidende beshuitvorming en hebben op het meetmoment nog geen effect op de organisatie van de directe begeleiding. Instelling $E$ heeft al enkele jaten een omslag naar een klantgerichte organisatie achter de tug en wijkt wat betreft structuur het meest af van de overige vier. Hier zijn ook alle woongroepen gehuisvest in gewone woningen in de samenleving. In alle instellingen is echter in gelijke mate sprake van een koppeling van een team van groepsleiders met een specifieke woongroep. Ook in geval woongroepen deel uitmaken van clusters, is binnen een dergelijk cluster sprake van allocatie van een team aan een woongroep. In drie gevallen was sprake van één team dat structureel zo was opgezet dat meerdere (kleine) woongroepen werden bediend. Deze woongroepen doen niet mee in dit onderzoek. In enkele gevallen leverde de instelling ondersteuning aan zelfstandig wonende cliënten op basis van persoonsgebonden budget. Ook deze situatie is niet meegenomen in het onderzoek. Tot slot werden woongtoepen uitgesloten die minder dan één jaar bestonden of waar in de loop van het afgelopen jaar de samenstelling van de bewoners ingrijpend (méér dan 50\%) was veranderd. In bijlage B7.1 zijn de populatiekenmerken van de afzonderlijke instellingen opgenomen; informatie over verloop en ziekteverzuim in de afzonderlijke instellingen is opgenomen in tabel B7.2.

De dataverzameling vond plaats in een periode waarin het verloop onder groepsleiders landelijk gezien hoger was dan in de voorafgaande jaren. Dit wordt weerspiegeld in het verloop in de onderzochte instellingen (tabel B7.2).

Tabel 7.1 Kenmerken wan de totale populatie van de vijf algenene instellingen in de onderzocksgroep ('vivea functioneten' en 'leeftijd") vergeleken met de landelijke pojpulatie van algemene instellingen".

\begin{tabular}{|c|c|c|c|c|c|c|c|}
\hline \multirow[b]{3}{*}{ Leetud } & \multicolumn{7}{|c|}{ Niveau funcroneren } \\
\hline & \multicolumn{6}{|c|}{ Instellingen in allat anderzok } & \multirow{2}{*}{ 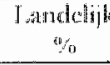 } \\
\hline & Wicht & Matig & Eirngtig & Zeer ernstig & "Tonal. & $\%$ & \\
\hline$<20$ & 19 & 42 & 26 & 42 & 129 & 7,1 & $B$, \\
\hline $20<<40$ & 53 & 180 & 185 & 196 & 614 & 33,9 & 385 \\
\hline $40<60$ & 57 & 296 & 250 & 172 & 775 & 42,8 & 40,7 \\
\hline $60<80$ & 26 & 122 & 89 & 25 & 262 & 14,4 & 12,1 \\
\hline $80<$ & 7 & 11 & 11 & 4 & 33 & 1,8 & 1,6 \\
\hline Torasal & 162 & 651 & 561 & 439 & 1.813 & & $(341079 \%$ \\
\hline$\%$ & 8,9 & 36,0 & 30,9 & 24,2 & & 100 & \\
\hline$\%$ Landclik & $9 x^{3}$ & 32,9 & 31.5 & 26,3 & & & 100 \\
\hline
\end{tabular}

"Berekend op basis wan LRZ gegevens: VGN, 2002 


\subsection{Methode}

Deze studie betreft cen kwantitatief, cross-sectioneel onderzoek (uitgevoerd op éen moment in de tijdy met een exploratief karakter. Er is gekozen voor de surveymethode om op een snelle, gestandaardiseerde en economische wijze een groot aantal gegevens te kunnen verzamelen. Met de ontwikkeling van de vragenlijsten werd rekening gehouden mer de aanbevelingen van De Jonge \& Hamers (1997). De gebruikte vragenlijsten staan in bijlage B7.8 en B7.9. Dataverzameling vond plaats in de periode tussen 1 november 2001 en 31 januari 2002; de data met betrekking tot personeelswisselingen hebben betrekking op de periode 01.01.2001 tot 31.12.2001 en beslaan daarmee een volledig jaar.

Personeelswisselingen doen zich in de context van ons onderzoek voor op bet miteau yan een woongropteam. Daarmee is ook het aggregatieniveau van het onderzock aangegeven: de analyse eenheid is de 'woongroep'. Individuele bewonerskenmerken (roals bijvoorbeeld zorgzwaarte) en alle op individuele respons gebaseerde gegevens werden geaggregeerd op het betreffende woongroepniveau. Dat betekent dat in dit onderzoek de data op individueel niveau niet worden gebruikt bij de dataanalyse. Met de vragenlijsten werd naast de informatie over de onderzoeksvariabelen de volgende achtergrondinformatie verzameld:

- Medewerkers:

Functic, geslacht, leeftijd en tijd werkzaam bij werkgever.

- Familie:

Relatic met bewoner, geslacht en leefrijd.

Van deze achtergrondinformatie wordt in hoofdstuk 7 gebruik gemaakt bij de beschrijuing van de resultaten van de vragenlijsten; verder wordt deze niet betrokken in ons onderzoek.

Daatenboven werd zowel aan medewerkers als familie de mogelijkheid geboden om antwoord te geven op twee open wragen met betrekking tot de kwaliteit van zorg. De antwoorden hierop maken geen deel uit van deze studie.

\subsection{Operationalisering van de onderzoeksvariabelen en gebruikte meetinstrumenten}

\subsubsection{Personeelswisselingen}

Her begrip 'personeelswisselingen' (als groepsvatiabele afgekort tot 'PW') verwijst naar veranderingen in de bezetting van de formatie groepsleiders die aan cen bepaalde woongroep is toegewezen. Met formatie wordt in dit onderzoek bedoeld: de 'vaste' formatie van medewerkers; daarmee zijn stageplatsen, ook van BBL leetlingen, uitgesloten. In deze formatie kunnen verschillende functies begrepen zijn waaronder '(groeps)hoofd', 'teamhoofd', 'groepsbegeleider', 'medewerker groepsbegeleiding', en 'huishoudelijke medewerker'. Andere gebrukte benamingen binnen de onderzochte instellingen zijn: 'zorgmedewerker', 'ondersteunend zorgmedewerkers', 'gastwrouw / gastheer', 'weekend medewerker". Het gaat in alle gevallen 
om medewerkers die directe begeleidingscontacten hebben met de clienten en deel uitmaken van het woongroepteam. Een verandering of 'wisseling' kan bekeken worden als uitstroom van een bekende medewerker of instroom van een nieuwe medewerker. Uitstroom en instroom zijn niet noodzakelijk gelijk; zo kan één voltijds werkende medewerker worden vervangen door twee of drie deeltijd medewerkers, of vice versa.

Braddock en Mirchell bevelen aan (paragraaf 3.2.4) om in dit soort onderzoek meerdere maten van 'verloop' te hanteren ondat daarmee verschillende modaliteiten kunnen worden bestreken en het inzicht kan worden vergroot. De veertien maten uit tabel 3.2 werden herleid tot drie typen maten van personeelswisselingen waarmee nu de volgende drie variabelen worden geformuleerd.

Type (I) geeft de uitstroom van groepsleiders weer uit een gegeven startbezeting over een periode van één jaar. Een lage uitstroom duidt op een hoge stabiliteit van het team. Type (II) geeft het aantal instromers of 'nieuwe gezichten' weer waatmee de bewoners van een woongroep in de loop van een jaar worden geconfronteetd. Een hoge waarde duidt op hoge instroomfrequentie van nieuwe teamleden die met de bewoners en hun collega's van het team moeten bekend geraken. Type (III) geeft aan hoe lang teamleden op een gegeven moment gemiddeld binnen het team functioneren.

De operationalisering is als volgt.

A. STABLLITEIT INDEX (STAB). Deze maat heeft betrekking op de samenstelling wan het woongtoepteam in de periode van de afgelopen 12 maanden ( 52 weken). Er wordt gekeken naar het aantal groepsleiders dat deel uitmaakt wan het team in week 1 , en nog voorkomt op het dienstrooster in week 52. Het aantal medewerkers dat op beide lijsten voorkomt wordt gedeeld door het aantal teamleden in week 1 en vermenigruldigd met 100. Als een team in week 1 bijvoorbeeld bestond uit 9 medewerkers ( $a, b, c, d, e, f, g$, h en i) en het team in week 52 bestaat uit 11 medewerkers $(\mathrm{a}, \mathrm{b}, \mathrm{d}, \mathrm{e}, \mathrm{g}, \mathrm{i}, \mathrm{i}, \mathrm{k}, \mathrm{l}, \mathrm{m}$ en $\mathrm{n})$ dan is de stabiliteitsindex $(6: 9) \times 100=67$ : van her team van negen groepsleiders in week 1 worden 6 medewerkers aangetroffen in week 52 . De maximumwarde van deze index is 100 ; de minimumwarde is 0 . Deze index geeft een maat voor de stabiliteit van de vast toegewezen groepsleiders van een woongroep; een hogere STAB-waarde verwijst naar 'meer stabiliteit'. Fien hogere STAB waarde wordt in dit onderzoek als positief geinterpreteerd. Voor de berekening van de STAB wordt gebruik gemaakt van informatie van de definitieve dienstroosters. Deze mat zegt echter niets over tussentijdse personeelswisselingen.

B. INSTROOM FREQUENTIE (INFR). Deze maat geeft aan hoe vaak de bewoners van een woongroep in de loop van een jaar (52 weken) worden geconfronteerd met een nieuwe groepsleider. Hierbij wordt het aantal nicuw instromende groepsleiders in de periode van de afgelopen 12 maanden ( 52 weken) geteld zoals die op het dienstrooster worden aangetroffen, gedeeld door het gemiddeld aantal groepsleiders van de woongroepformatie in dezelfde periode, en vermenigruldigd met 100 . Als de bewoners van een woongroep bijvoorbeeld 18 nieuwe groepsleiders ont- 
moeten, terwil de totale formatie groepsleiders gemiddeld bestaat uit 10 medewerkers, dan bedraagt de INFR $(18: 10) \times 100=180$. De minimumwaarde wan deze index is 0 . Et is in principe geen maximumwaarde. De INFR maat is gevoelig voor personeelswisselingen als gevolg van bijvoorbeeld vervanging voor ziekte en ouderschapsverlof, en voor instroom van tijdelijke medewerkers en opsplitsing van een bepaalde formaticplaats in meerdere (bijwoorbeeld: een full time positie wordt gesplitst in twee half time positics). Een hoge INFR waarde verwijst naar "meer personeelswisselingen". Een hogere INFR waarde wordt in dit onderzoek als negatief geinterpreteerd.

Voot de berekening van de INFR wordt gebruik gemaakt van informatie van de definitieve dienstroosters. Wanneer een groepsleider in de loop van de 52 weken periode méér dan één keer 'instroomt', wordt dit als één instroom geteld: de betreffende groepsleider wordt geacht cen zekere bekendheid te hebben met bewoners en collega's en niet een geheel 'nieuw gezicht' te zijn.

C. TIJD OP WOONGROEP (TOWG). Deze maat geeft het gemiddelde aantal maandet dat de groepsleiders - op het moment van meting - deel uitmaken wan her betreffende woongroepteam. Het bleek niet mogelijk deze informatie uit dienstroosters of andere centrale databases van de instellingen te verkrijgen. Daarom werd in het enquêteformulier voor medewerkers gevraagd an te geven hoe lang de respondent werkzaam was in de betreffende groep (zie bijlage B7.8, vraag 5). De individuele TOWG waarden zijn hiervan afkomstig en werden geaggregeerd op woongtoepniveau tot de gemiddelde verblijfsdur van teamleden binnen een bepaald woongroepteam. Een hogere TOWG waarde wordt in dit onderzoek als positief geinterpreteerd.

Bij het berekenen van de PW maten is geen onderscheid gemaakt tussen functies, interne vervangingen of uitzendkrachten, overplaatsingen of verloop. Vanuit het perspectief van de bewoner zijn deze kenmerken minder relevant: het gaat om mensen in zijn omgeving die vertrekken of binnenstromen. Recent is gebleken dat, althans voor de implementatie van opvoedingsprogramma's in woongroepen van ernstig meervoudig gehandicapten, personeelswisselingen al naargelang de functie van groepsleiders, verschillende effecten kan hebben. Het betreft dan vooral stagiaires en invalkrachten (Zijlstra, 2003). Stagiaires maken geen deel uit van het door ons onderzochte 'vaste team'; 'invalkrachten' worden in ons onderzoek alleen meegenomen wanneer zij vaste teamleden vervangen.

De gegevens voor berekening van de STAB en INFR maten werden om reden van zorgvuldigheid twee maal onafhankelijk van elkaar verzameld; een STAB of INFR mat werd pas ingevoerd bij volledige overeenstemming. 


\subsubsection{Woongroepkenmerken}

Uit de in hoofdstuk 3 (zie tabel 3.1 en paragraaf 3.2.5) gevonden relevante organisatiekenmerken (significante correlaten van verloop) werden in hoofdstuk 5 de volgende organisatiekenmerken respectievelijk woongroepkenmerken geselecteerd:

1. De instelling waartoe de woongroep behoort (INST).

2. De omvang van de clustering waarin de betreffende woongroep is opgenomen (CLUS).

3. Of het een woongroep op het instellingstertein of daarbuiten betreft ( $\mathrm{SOCW}$ ).

4. De grootte van de woongroep in aantal bewoners (NBEW).

5. De zorgzwaarte wan de woongroep (ZOZW).

De operationalisering is als volgt.

Ad 1. INSTELLING (INST) verwijst naar de instelling waartoe de woongroep behoort. In deze studie gaat het derhalve om INST A,B,C,D, en E.

Ad 2. CLUSTER (CLUS) geeft het totaal aantal woongroepen aan in het organisatorische cluster waarvan de betreffende woongroep deel uitmaakt. Het gaat om het eerstrolgende hogere niveau van groepering van woongroepen; in alle gevallen betreft dit het niveau warop beslissingen over de bezetting van de teamformaties worden genomen. Een cluster kan onder leiding staan van een 'afdelingshoofd', 'clusterhoofd', of 'clustermanager'. De minimale omvang is én; dit is het geval indien het woongroepteam organisatorisch als een zelfstandige eenheid functioneert. Deze informatie werd binnen de instellingen verzameld.

Ad 3. SOCIOWONING (SOCW) geeft an of de woongroep gesitueerd is op of buiten het instellingsterrein. De waarde [1] betekent instellingsterrein; [2] is sociowoning. Deze informatie werd binnen de instelling verzameld.

Ad 4. GROOTTE WOONGROEP (NBEW) is het daadwerkelipke antal bewoners van de woongtoep op de datum van het onderzoek zoals vastgelegd in de bewonersadministratie van de instelling.

Ad 5. ZORGZWAARTE (ZOZW) is gebaseerd op de classificatie 'niveau van functioneren' van de individuele bewoners wan de woongtoepen zoals vastgelegd in de bewonersadministratie op basis van het oordeel van een psycholoog of (ortho-) pedagoog van de instelling. ZOZW geeft het petcentage bewoners van de betreffende gtoep weer dat behoort tot de classificatie 'zeer ernstige' of 'ernslige' verstandelijke beperkingen, uit de gangbare vierdeling van niveaus van functioneren (World Health Organization, 1993) die in elke instelling verplicht wordt geregistreerd ten behoeve van de zorgkantoren. Deze ordinale niveauclassificatie weerspiegelt globaal de zorgzwaarte van mensen met verstandelijke beperkingen. Voor deze maat is gekozen omdat de instellingen ten tijde van het onderzoek geen 
onderlng vergelykbare maat woor zorgzwaarte gebrukten, maar wel de bekende niveau-indeling hanteren. Het relatiewe aantal bewoners met de (ordinale) classificatie 'ernstige' en 'zeer enstige' verstandelijke beperkingen wordt als indicatie van zorgzwarte gebruikt. Met deze zorgzwaarte-maat werd eerder etvaring opgedaan (Buntinx, 2001; 2002). Inmiddels is empirisch aangetoond dat de gebruikelijke niveau-indeling inderdaad significante verschillen weerspiegelt in onafhankelijk gemeten zorgintensiteit ( $V$ an Unen, 2003). Een lage ZOZW waarde betekent dus relatief weinig bewoners met de classificatie 'zeer ernstig' of 'ernstig' en weerspiegelt daarmee een relatief lagere zorgzwaarte. Een hogere waarde verwijst naat hogere zorgzwatte. Een percentage van 0 betekent dat geen van de bewoners behoren tot de classificaties 'zeer ernstig' of 'ernstig'. Een percentage van 100 betekent dat alle bewoners tot (één van) deze classificaties behoren.

\subsubsection{Teameffectiviteit}

Tot de reameffectiviteit horen vier verschillende werkreacties van groepsleiders. Deze ontlenen hun relevantie aan het in paragtaaf 4.1.6 gepresenteerde theorerisch model dat deze werkreacties karakteriseert als effectiviteitaspecten. Het betreft:

1. Arbeidssatisfactic (MAS).

2. Rolduidelijkheid (ROL).

3. Vertrouwen in doelmatigheid van het team (VER).

4. Ervaren autonomie of empowerment (AUT).

De operationalisering is als volgt.

Ad 1. ARBEIDSSATISFACTIE (MAS) is de totaluitslag op de MAS-GZ, de Maastrichtse Arbeidssatisfactieschalal woor de Gezondbeidszorg (Landeweend, Boumans \& Nissen, 1996). De MAS-GZ steunt op een facematige benaclering van arbeidssatisfactie en meet zeven onderscheiden werkfacetten. De MAS-GZ meet, naast algemene tevredenheid (som van alle facetten), de tevredenheid met:

1. het afdelingshoofd (LEID),

2. promotiemogelijkheden (PRO),

3. kwaliteit van (geleverde) zorg (KWA),

4. collega's (COL),

5. clïnten (CLI),

6. gebruik van eigen competenties (COM),

7. duidelijkheid (DUI).

De facetuitslag is gebaseerd op de som van telkens drie vragen. De totale MAS-GZ uitslag is gebasect op 21 vragen. Elke vraag wordt beoordeeld op een vijfpuntenschaal (1-5).

De constructvaliditeit van de MAS-GZ steunt op factoranalytisch onderzoek. De interne consistentic van de schaal is goed (Cronbach's alpha: 85). Naast de goede psychometrische eigenschappen rormde het feit dat de MAS-GZ eveneens aandacht schenkt aan het oordeel van de tespondenten over de doot hen geleverde kwaliteit en de relaties met cliënten, een argument voor de keuze voor de MAS-GZ. 
Door de facetbenadering kunnen afzonderlijke aspecten van arbeidssatisfactie eveneens worden meegenomen in het onderzoek. Zo kan worden nagegaan welke facetten bijzonder van belang zijn in relatie tot door familie ervaren kwaliteit. De MAS-GZ uitslag is de gemiddelde itemscore. Hoe hoger de nitslag, hoe groter de tevredenheid. Bij de verwerking van de uitslagen werden maximal twee missing values voor de hele schaal geaccepteet; er werd in dat geval ongerekend nat 21 items. Bij een groter aantal ontbrekende iremscores wordt de hele schaluitslag als 'missing" aangemerkt. De gebruikte MAS-GZ vragenlijst stat in bilage B7.8 (deel 1).

Ad 2. ROLDUIDELIKHEID (ROL) is de gemiddeld behaalde score op de zeventien items van de Role. Ambigzaty schaal van Hartine \& Ferrell $(1996$, p. 67). De interne consistentie van deze schaal is goed (Cronbach's alpha: 91). De conceptvaliditeit en ctiteriumvaliditeit met andere schalen is verantwoord in Hattline \& Ferrell (1996). De items werden vertaald en waar nodig toegesneden op de zorgsector. Daarbij werd gebruik gemaakt van de Nederlandse aanpassing van De Jong (2001). De respondent wordt gevraagd op een zevenpuntenschaal $(1-7)$ aan te geven in welke mate hij het eens is met elk van zeventien beweringen over de ervaren rolduidelijkheid in de werksituatie. Hoe hoger de uitslag, hoe meer duidelijkheid over de rolvervulling binnen het team. De uitslag is de gemiddelde itemscore. Bij de verwerking werden maximaal 2 ontbrekende antwootden geaccepteerd. In voorkomend geval werd de uitslag omgerekend naar 17 items. Bij meer ontbrekende items wordt de hele schaaluitslag als 'missing' aangemerkt. De gebruikte vragenlijst rolduidelijkheid staat in bijlage B7.8 (deel 2).

Ad 3. VERTROUWEN IN DOELMATIGHEID (VER) is de gemiddelde uitslag op een schaal van zeven items waamee het vertrouwen van teamleden in de coelmatigheid van hun samenwetking wordt gemeten. In Hartine \& Ferrell's model neemt deze variabele een belangrijke plaats in. "Toch werd afgerien van gebruik van hun meetinstrument (de Employe Self-Effraw stbad, Cronbach's alpha: 67) en wordt de voorkeur gegeven aan een gelijksoorrige schaal van Alper - de Confidence in Team Dynamics schal (Alper, 1998, p. 48) - omclat deze meer is toegesneden op het werken in teanverband én betrouwbaarder is (Cronbach's alpha: 87). Alper's schaal werd vertaald en aangepast aan de setting van woongroepteams in residentiële instellingen. Daarbij werd gebruik gemaakt van de Nederlandse aanpassing door De Jong (2001). Deze schaal meet eveneens de mate waarin teamleden vertrouwen hebben in het doelmatig funcrioneren van hun team als zodanig. De items worden gescootd op een zevenpuntenschaal (1-7). De uitslag is de gemiddelde itemscore. Hoe hoger de uitslag, hoe groter her vertrouwen in eigen teamdoelmatigheid. Bij de verwetking werd slechts één ontbrekend antwoord geaccepteerd. In vootkomend geval wordt de uirslag omgerekend naar 7 items. Bij meerdere ontbrekende antwoorden wordt de schaaluitslag als 'missing' aangemerkt. De gebruikte vragenlijst 'verttouwen in doelmatigheid' staat in bijlage B7.8 (cled3). 
Bij de verwerking van de vragenligstantwoorden werd de score op de negatief geformuleerde vragen 2 en 4 omgewaardeerd.

Ad 4. ERVAREN AUTONOMIE (AUT) is de gemiddelde uitslag op een schaal wan 8 items die nagat in welke mate de respondent vindt dat zijn team ovet autonomie beschikt. Het betreft de Expowement schal van Hartline \& Ferrell (1996. p.67) die meet in hoeverre medewerkets ervaren dat hun leidinggevenden ruimte laten om eigen initiatief te tonen en om het eigen oordeel te volgen bij het uitwoeren van het werk. De auteurs verantwoorden in de genoemde publicatie de conceptraliditeit en de constructvalidireit wan deze schaal. De betrouwbarheid is voldoende (Cronbach's alpha: .71). Ook bij de aanpassing van deze schaal aan de setting van woongroepteams in een residentele organisatie werd gebruik gemaakt van de Nederlandse aanpassing door De Jong (2001). De items worden beoordeeld op een zevenpuntenschal (1-7). De uitslag is de gemiddelde itemscote. Hoe hoger de uitslag, hoe meer ruimte voot eigen initiatief wordt ervaren. Bij de verwerking wordt slechts éen ontbrekend antwoord geaccepteerd. In voorkomend geval. wordt de uitslag omgetekend naar 7 items. Bij meer ontbrekende antwoorden wordt de schaaluitslag als 'missing' aangemerkt. De gebruikte vragenlijst 'ervaren autonomie" staat in bijage 7.8 (deel 4 ).

\subsubsection{Ervaren kwaliteit van begeleiding}

HARC is de gemiddelde uitslag op negen items uit de Hester. Adrian Reseanch Center Fanzily Questionnaire. Deze schal werd ontwikkeld door Eric Emerson voor onderzoek in Engelse residentiele voorzieningen voor mensen met verstandelije beperkingen (Hatton, Emerson, Robertson, Henderson \& Cooper, 1995). De schaal neet de door familie ervaren kwaliteit van zorg en is gebaseerd op negen aspecten van begeleiding. Uit factoranalyse (principale componenten: tabel B7.3) blijkt slechts één component te kunnen worden geextraheerd. In overeenstemming met de atrd van de items wordt deze benoemd als: inhoudelijke (in Grönroos termen: "technische") kwaliteit van begeleiding. De Cronbach's alpha van de HARC is 91 in cen steckptoef van $\mathrm{N}=182$ (persoonlijke mededeling van de auteur, 2000). De items worden beoordeeld op een zevenpuntenschaal (1-7). De uitslag is de gemiddelde itemscore. Hoe hoger de uitslag, hoe grotet de tevredenheid met de inhoudelijke aspecten van begeleiding. Bij de verwerking werd één ontbrekend antwoord geaccepteend en werd de uitslag op 8 items omgetekend naar een uitslag op 9 items. Bij mecrdere ontbrekende antwoorden werd de schaal niet gescoord. Deze vragenlijst stat in bijlage B7.9 (deel 2, B, vragen 1 tot en met 9 ).

CPSQ is de gemiddelde uitslag op de tien items van de Customer Peneined Sentue Qualty schaal van Hartine en Ferrell (1996, p. 68). Deze schaal is gebaseend op de SERVQUAL en meet de doot de clent erwaren kwaliteit van dienstverlening. Her gaat daarbij niet over technische of inhoudelijke aspecten van de dienstverlening, mar over de wijze watop from-line medewerkers hun taken uitvoeren in interactic 
met het clièntsysteem. Het gaat om aspecten van bejegening, communicatie cn vertrouwen. In Grönroos' termen gaat het om de functionele kwaliteit van dienstverlening. Vanwege het accent op de interactieaspecten tussen front-line medewerkers en cliëntsysteem, spreken we over 'relationele kwaliteit' (zie de bespreking in paragraaf 6.3.2-3). Deze schaal combineert de perspectieven 'verwachte' en 'ervaren' kwaliteit in éen meting (paragraaf 6.3.2-3). De betrouwbaarheid van de CPSQ is goed (Cronbach's alpha: 97). De items worden beoordeeld op een zevenpuntenschaal (1-7). De uitslag is de gemiddelde itemscore. Hoe hoger de score, hoe groter de tevredenheid met de relationele aspecten van de dienstverlening ten opzichte van de familieleden. Er werd maximaal één ontbrekend antwoord geaccepteerd en zonodig werd de somscore op negen items omgerekend naar 10. Bij meerdere ontbrekende antwoorden wordt de schaaluitslag niet meegenomen en als 'missing' aangemerkt. Deze vragenlijst staat in bijlage B7.9 (deel 3).

In tabel 7.2 worden de gegevens over de interne consistentie van de gebruikte schalen samengevat.

Thathe 7.2 Overzicht van de variabelen en de gebrukte meetinstrumenten met vermelding van de interne consistentie (Cronbach's alpha) volgens opgawe van de auteurs en zoals gevonden in ons onderzoek.

\begin{tabular}{|c|c|c|c|c|c|}
\hline Variable & Mectinstrument & $\begin{array}{l}\text { Aantal } \\
\text { itenns }\end{array}$ & $\begin{array}{l}\text { Alptia } \\
\text { aureurs }\end{array}$ & $\begin{array}{l}\text { Alpha deze } \\
\text { studie }\end{array}$ & Auteurs \\
\hline \multirow[t]{9}{*}{ MAS } & $\begin{array}{l}\text { Atbeid satisfactie (MAS- } \\
\text { GL) }\end{array}$ & & & & 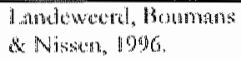 \\
\hline & Totale schand & 21 & .85 & .88 & \\
\hline & $1.1 \%$ & 3 & .87 & 81 & \\
\hline & 380 & 3 & .84 & 84 & \\
\hline & $k x_{i}$ & 3 & .82 & .78 & \\
\hline & Col & 3 & .73 & .75 & \\
\hline & CLI & 3 & .73 & .69 & \\
\hline & (C) & 3 & .67 & .77 & \\
\hline & DUI & 3 & 60 & .61 & \\
\hline ROL & Rolduiduelijkheid & 17 & .91 & .86 & $\begin{array}{l}\text { Hatline \&e lerrelli. } \\
\text { logr. }\end{array}$ \\
\hline VER & $\begin{array}{l}\text { Vertrouwen in } \\
\text { texmfunctioneten }\end{array}$ & $?$ & .87 & .89 & Alpor, logs \\
\hline AUT & Autonomie & 8 & .71 & .85 & 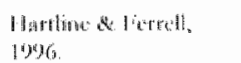 \\
\hline HARC & $\begin{array}{l}\text { Hester Adrian Reseinch } \\
\text { Center Gamily } \\
\text { Quesuiornaita }\end{array}$ & 9 & 9 & 91 & lingersion, loges. \\
\hline $\operatorname{CPSQ}$ & $\begin{array}{l}\text { Customer Perceived Service } \\
\text { Quallity }\end{array}$ & 10 & .97 & .94 & $\begin{array}{l}\text { Hartinge diceredl, } \\
\text { logo. }\end{array}$ \\
\hline
\end{tabular}

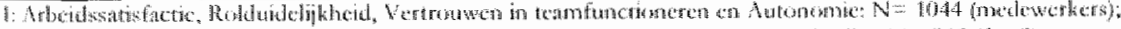

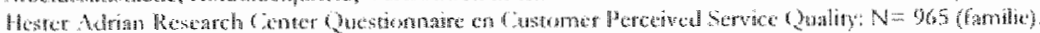

\subsection{Procedure}

Aan de directie en de cliëntenraad of ethische commissie van de instellingen werd toestemming gevraagd yoor het onderzoek. Deze werd verkregen onder vootwaarde van volstrekte anonimiteit van verwerving en verwerking van gegevens. 
De verzonden vragenlijsten waren volstrekt anoniem en in overleg met de instelling slechts voorzien van een woongroepcode, dus geen individuele code. De vragenlijsten werden door de instelling persoonlijk geadressectd aan her thuisadres van medewerkers en familieleden; elke vragenlijst ging vergezeld van een brief met toelichting (zie bijlage B7.4 en B7.5) en een antwoordenveloppe, geadresseerd aan de universiteit. Tot de 'medewerkers' horen alle leden van de woongroepteams inclusief meewerkende leidinggevenden. Tot de 'familie' horen de belangrijkste contactpersonen (contactadres) van de bewoners van een woongroep; dit kumen ook een broer of zus zijn, of andere familieleden of personen die geen familie zijn maat wel de meest relevante contacten hebben met de bewoner. Als gevolg van de strikte anonimiteiteisen werd geen individuele registratie bijgehouden en was het derhalve niet mogelijk onderscheid te maken tussen personen die de vragenlijst wel of niet hadden ingezonden. Na drie weken werd aan alle betrokkenen via dezelfde weg een algemene bedankbrief wan de onderzoeker gestuurd die tevens als rappelbrief diende (bijlage B7.6 en B7.7).

De data met betrekking tot de Woongroepkenmerken en de Personeelswisselingen werden betrokken uit het bestaande cliëntregistratiesysteem respectievelijk uit de dienstroosters van de instellingen. Deze data werden door functionarissen van de instellingen anoniem en geaggregeerd aangeleverd. Data met betrekking tor de variabelen Teamfunctioneren en Ervaren Kwaliteit van begeleiding werden verzameld door middel van een vragenlijst voor medewerkers respectievelijk voor familieleden van bewoners. Een model van elke vragenlijst is opgenomen in de bijlagen B7.8 en B7.9.

\subsection{Data analyse}

De data van de hierboven beschreven maten en kenmerken werden ingevoerd in het programma Access (Microsoft Office, 1998) aan de hand van speciaal daartoe opgestelde invoemodules (medewerkers en familie). 15 procent van de invoer werd rer controle onathankelijk opnieuw ingevoerd. Op grond van deze controle en de zonodig angebrachte correcties kan de betrouwbaatheid van de invoerprocedure als overeenkomst tussen antwoorden op papier en data in de databases worden gesteld op beter dan 99,74 procent voor de medewerkersiata en beter dan 99,98 procent voor de familiedata. Beide databases werden vervolgens geaggregeerd tot én derde database op woongroepniveau waaraan de woongroepkenmerken en maten voor personeelswisselingen wetden toegevoegd.

Zo ontstonden drie darabases: (1) vragenlijst medewerkers, (2) vragenlijst familie en (3) woongroepen. Elke database werd ingevoerd in SPSS 10.0. Met deze drie SPSS datafiles is het onderhavige onderzoek uitgevoerd. Infotmatie uit de databases 1 en 2 wordt als achtergrondinformatie gepresenteerd; de beantwoording van de onderzoeksvragen en deelvragen gebeurt met de geaggregeerde woongroepgegevens van database 3.

De beantwoording van de onderzockswragen gebeurt in een 'stap voor stap' procedure. 
Bij de analyse van de continue variabelen zal overwegend gebruik worden gemaakit wan correlatieberekening. Bij categoriale variabelen zal gebruik worden gemaakt van ANOVA. Verder wordt bij de beantwoording van onderzoekswraag 5 gebruik. gemaakt van regressietechniek om moderatoreffecten wan personeelswisselingen op het verband tussen teamfunctioneren en door familie ervaren kwaliteit van begeleiding ta te gaan. Bij onderzoeksvraag 6 wordt gebruik eerst een mulrilevel toetsing uitgevoerd met MLWIN en vervolgens een path-anabsis (pad analyse) uitgevoerd naar analogie van de werkwijze van Hatton et al. (1999) en Hatton et al. (2001). Significanties worden in dit verslag verder aangegeven met * voor $\mathrm{p}<0,05$ of *** voot $\mathrm{p}<0,01$. Bij de uitkomsten van regressieanalyses worden de $\mathrm{p}$-watrden vermeld.

\subsection{Geoperationaliseerde onderzoeksvragen}

$\mathrm{Na}$ operationalisering van de variabelen kunnen de onderzoeks(dee) vragen als volgt worden gefomuleetd. Iedere deelvraag zal afzonderlijk worden beantwoord voor elke $\mathbb{P W}$-maat $(S T A B=a ; I N F R=b ; T O W G=c)$.

1. Is er en verband tussen personeelawisselingen en organisatiekengmerken?

1.1. Is er een verband tussen de omvang van $P W$ en de factor 'instelling' $(A, B$, $C, D$, en $E$ )?

1.2. Is er een verband tussen de omvang van PW en de grootte van clusters van woongroepen (CLUS)?

1.3. Is er een verband tussen de omvang van PW en de situering van woongroepen op, respectievelijk buiten het terrein (SOC)?

1.4. Is er een verband tussen PW en de grootte van woongroepen (NBEW)?

1.5. Is er een verband tussen $P W$ en de zorgzwarte van woongroepen (ZOZW)?

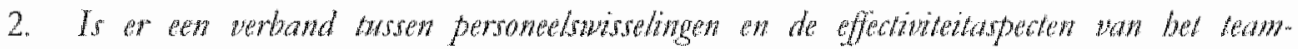
functioneren?

2.1. Is er een verband tussen PW en arbeidssatisfactic (MAS)?

2.2. Is er een verband tussen PW en rolduidelijkheid (ROL)?

2.3. Is er een verband tussen $P W$ en vertrouwen van het team in eigen doelmatigheid (VER)?

2.4. Is er een verband tussen PW en de door de reamleden ervaren autonomic (AUT)?

3. Is er een werbasd twssen personeelswisselingen en door fonnilie envarn kwaliteit wath begeleiding?

3.1. Is er een verband tussen PW en de door familie ervaren inhoudelijke kwaliteit van begeleiding (HARC)?

3.2. Is er een verband tussen PW en door familie ervaten relationele kwaliteir van de begeleiding (CPSQ)? 


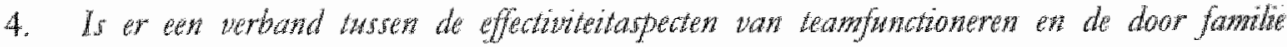
enaren kewaliteit wan begekeding?

4.1. Is er en verband tussen enerzijds MAS en anderzijds HARC en CPSQ?

4.2. Is er een verband tussen enerzijds ROL en anderzijds HARC en CPSQ?

4.3. Is er een verband tussen enerzijds VER en anderzijds HARC en CPSQ?

4.4. Is er een werband tussen enerzijds AUT en anderzijds HARC en CPSQ?

5. Welke rol spelen personedswisselingen bij bet werband inssen de effectiviteit van bet kanfanctioneron en do door familie wan bewoners erwaren kualiteit wan begeleiding?

5.1. Vomen PW een moderator wan het verband tussen effectiviteitaspecten van het teamfunctioneren (MAS, ROI, VER en AUT) en door familie ervaren inhoudelijke kwaliteit van begeleiding (HARC)?

5.2. Vormen PW cen moderator wan het verband tussen effectiviteitaspecten van het teamfunctioneren (MAS, ROL, VER en AUT) en door familie ervaren relationele kwaliteit van begeleiding (CPSQ)?

6. Kan een model wotden opyesteld wan de samenhang tussen (1) woongroepkenmerken, (2) personelswisselingen en (3) teameffectiviteit als woorspellers van de door fomilie evanen

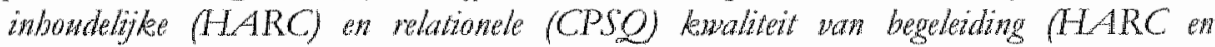
CPSQI?

Fit zal een pad-model worden geconstrueerd (1oehlin, 1998) van alle gebruikte variabelen - gegroepeerd naar woongroepkenmerken, personeelswisselingen en teameffectiviteit - om de variantie in door familie ervaren kwaliteir van begeleiding te verklaren. 
In dit hoofdstuk worden de resultaten gepresenteerd wan het empirisch onderzoek. Het hoofdstuk begint met een beschrijving van de respons (8.1) en van de uitkomsten op de vatiabele personeelswisselingen (8.2). Vervolgens worden stap voor stap de uitkomsten gepresenteetd met betrekking tot de onderzoeks(deel)vragen naar het verband tussen petsoneelswisselingen en achtereenvolgens onganisatiekenmerken (8.3), teameffectiviteit (8.4) en door familie ervaren kwaliteit van begeleiding ( 8.5$)$. In paragraaf 8.6 volgen de uitkomsten van het verband tussen teameffectiviteit en de door familie ervaren kwaliteit van begeleiding. In paragraaf 8.7 worden de moderatoreffecten van personeelswisseling op het verband tussen effectwiteitaspecten en door familie ervaten kwaliteit van begeleiding beschreven. In paragraaf 8.8 worden de uitkomsten van de pad analyse behandeld waarin organisatiekenmerken, personeelswisselingen en teameffectiviteit als voorspellers worden gebrukt van door familie ervaren kwaliteit van begeleiding.

\subsection{Respons}

Van de 1.768 aan medewerkers toegezonden vragenlijsten werden er in totaal 1.151 gertoumeerd $(65 \%)$. Van de 1.703 aan familieleden toegezonden vragenlijsten werden er in totaal 1.021 geretourneerd $(60 \%)$. De responspercentages variëren tussen de instellingen van 76 tor $49 \%$ (tabel B8.1). Deze percentages zijn vergelijkbaar met, tor beter dan soortgelijk survey onderzoek zowel in Nederland (bijvoorbeeld: 51,8\% in Van der Ploeg \& Scholte, 1997; 43,5\% in Prismant, 2002) als in het buitenland (bijwoorbeeld: $44 \%$ in Hatton, Emerson, Rivers, Mason, Swarbrick, Mason, Kiernan, Reeves \& Alborz, 2001).

In total werden gegevens verzameld over 194 woongroepen. Drie bijzondere situaties waarin telkens één team de zorg had over één cluster van bewoners (17, 19 en 27 bewoners) in kleine groepjes in verschillende woningen, worden in de analyses vanwege het kleine aantal niet meegenomen. Hetzelfde geldt voor teams die gekoppeld zijn aan logeerhuizen, of minder den één jaar bestaan, of waarvan de bewonerssamenstelling meer dan 50 procent gewijzigd werd in de afgelopen twaalf maanden. Het totale aantal teams dat beschikbaar is voor data analyse bedraget daarmee 188.

\subsubsection{Medewerkers}

De verhouding man:vrouw is bij de responderende medewerkers 8:92 procent. De gemiddelde leeftijd van de respondenten is 34,6 jaar $(S D=9,8)$ : voor mannen is deze 35,5 en voor vrouwen 34,5 jaar. De gemiddelde tijd dat medewerkers bij de instelling werkzaam zijn bedraagt 8,8 (mannen) respectievelijk 8,9 (vrouwen) jaar. Tabel $B 8.2$ in de bijlage toont de verdeling van de respondenten over de verschillende functies bij de instellingen $A, B, C, D$ en $E$. 


\subsubsection{Familie}

De verhouding man:wrouw is bij de respondenten 43.57 procent. De leefrijd van de respondenten is normaal verdeeld rond het gemiddelde van 58,4 jaar ( $\mathrm{SD}=11,0)$. De gemiddelde leeftijd is 59,2 jaar voor mannen en 57,6 jaar voor vrouwen. Van alle respondenten is 44,8 procent vader of moeder en 45,4 procent broer of zus van de bewoner (tabel B8.3).

\subsubsection{Bias}

Een analyse van de non-respons was niet mogelijk omdat de gegevens van alle respondenten volstrekt anoniem dienden te worden verkregen; daardoor ontbrak de mogelijkheid om non-respondenten geticht te benaderen. Wel is gekeken naar het responspercentage op woongroep niveau. Omdat zowel het aantal medewerkers als het aantal familieleden (één per bewoner) aan wie een vragenlijst was gezonden bekend was, kon per leefgroep het responspercentage worden berekend. Langs deze weg is gezocht naar mogelijke bias in voor ons onderzoek belangrijke variabelen.

Bij de medewerkers is sprake van een bias op de variabele TOWG: er werd een significante positieve correlatie gevonden tussen het responspercentage per woongroep en de gemiddelde tijd die de respondenten werkzaam waren binnen hun woongroep $\left(\mathrm{r}=.29^{* *}\right)$. Hetzelfde geldt voor de variabele arbeidssatisfactic $(\mathrm{r}=$ $.28^{* * *}$ ). In woongroepteams met een hoog responspercentage worden hogere warden voor de 'tijd op woongroep' maat en voor arbeidssatisfactie aangetroffen. Omdat de uitkomsten op beide maten bij niet-respondenten mogelijk lager liggen, kan niet worden uitgesloten dat de vitkomsten op de 'tijd op woongroep' maat TOWG en de arbeidssatisfactie variabele MAS een zekere overscharting vormen van de werkelijke waarden in de populatie van de woongroepen. Het gemiddelde responspercentage van medewerkers in woongroepen 'op het terrein' is hoger (69\%) dan van medewerkers 'in sociowoningen' $(59 \%)$.

Bij de familie wordt ook een hoger responspercentage gezien in woningen op het terrein $(61 \%)$ versus sociowoningen $(55 \%)$. Er zijn geen significante correlaties tussen het responspercentage van familie in de woongroepen en de uirslagen op de variabelen HARC en CPSQ. Interessant is dat er cen significante correlatie van $\mathrm{r}=$ $.22 * *$ blijkt te bestaan tussen het responspercentage van de familic en de variabele rolduidelijkheid van de groepsleiding.

\subsection{Uitkomsten van de drie maten 'personeelswisselingen' (PW)}

In tabel 8.1 staan de uitkomsten van de drie PW-maten voor elke instelling afzonderlijk en voor de totale onderzoeksgroep.

De gemiddelde stabiliteit uitkomst (STAB) in de totale onderzoeksgroep bedtaggt $\mathrm{M}=66,5(\mathrm{SD}=21,5)$. Dit betekent dat gemiddeld over alle onderzochte woongroepteams, op het meetmoment nog 66,5 procent van de groepsleiders aanwezig 
is die één jaat ( 52 weken) eerder deel uitmaakten van het woongtoepteam. In de loop van een jaar is derhalve 33,3 procent van de groepsleiders uit de formatie verdwenen. De hoogste STAB is 100 (in 19 woongtoepen); de langste STAB is 0 (nwee woongroepen).

Tabel 8.1 Gemiddelde (M), standarddeviatie (SD), minimum en maximum warden van personeelswisselingen in de vijf instellingen afzonderlijk en total voot de maten stabilineit (STAB), instroomfrequentie (INFR) en "tijd op woongroep" (TOW $G$ )

\begin{tabular}{|c|c|c|c|c|}
\hline Enscelling & Waarde & $S T A B$ & MWFR & TOWG: \\
\hline \multirow[t]{4}{*}{$A$} & $\mathrm{M}$ & 58,6 & 527 & 40,5 \\
\hline & $5 D$ & 22,5 & 29.4 & $25 \%$ \\
\hline & Minimam & 23,1 & 0,0 & 7,0 \\
\hline & Maximum & $100 \mathrm{n}$ & 100,1 & 1227 \\
\hline \multirow[t]{4}{*}{$B$} & $M$ & 65,8 & 42,8 & 30,6 \\
\hline & $\mathrm{SD}$ & 17,6 & 21,1 & 189 \\
\hline & Minimum & 25,9 & 9,1 & 10,0 \\
\hline & Maximum & 100,0 & 87.5 & 87,8 \\
\hline \multirow[t]{4}{*}{ c } & $M$ & 655 & 73,8 & 45,3 \\
\hline & $\mathrm{SD}$ & 22,8 & 69.0 & 22,2 \\
\hline & Minimum & 0,0 & 15.4 & 7,0 \\
\hline & Maximum & 100,0 & 3500 & 81,7 \\
\hline \multirow[t]{4}{*}{$D$} & $\mathrm{M}$ & 68,2 & 100,6 & 67.8 \\
\hline & $\mathrm{SD}$ & 10,2 & 520 & 34,9 \\
\hline & Minitryum & 25,0 & 15,4 & 9.4 \\
\hline & Maximumn & 100,0 & 2667 & 142,7 \\
\hline \multirow[t]{4}{*}{$\mathrm{E}$} & $M$ & 72,5 & 53,0 & 26,2 \\
\hline & SD & 22,9 & 39,9 & 17,5 \\
\hline & Munimudum & 0,0 & 0,0 & 7,5 \\
\hline & Maximum & 100,0 & 133,3 & 89,0 \\
\hline \multirow[t]{4}{*}{ Total } & $M$ & 66,5 & 64,5 & 43,4 \\
\hline & $\mathrm{SD}$ & 21,5 & 48,8 & 28,3 \\
\hline & Minumem & 0,0 & 0,0 & 70 \\
\hline & Maximatm & 100,0 & 350,0 & 1427 \\
\hline
\end{tabular}

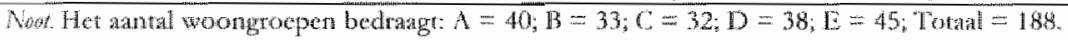

De gemiddelde instroomfrequentie (INFR) bedratagt $\mathrm{M}=64,5(\mathrm{SD}=48,8)$. Dit betekent dat gemiddeld genomen in een woongroepteam wan $\mathrm{n}$ medewerkers, rjdens het afgelopen jaar een aantal van ( $\mathrm{n} \times 64,5) / 100$ "nieuwe" medewerkers zijn ingestroomd. De laagste waarde is 0 procent; de hoogste waarde is een team met 350 procent; vijf woongroepen kenden een instroomftequentie van meer dan 200 procent.

De gemiddelde TOWG maat per woongroep bedraagt 43,4 maanden (SD $=28,3$ ). De laagste waarde wordt gezien in drie teams met een gemiddelde verblijfsduur van alle (responderende) groepsleiders van zeven maanden; de hoogste waarde is een team met gemiddeld 142 maanden; in negen teams is de TOWG hoger dan 100 maanden. De quartielcijfers zijn $Q_{25}=22,3 ; Q_{50}=37,6$ en $\left.Q_{75}=62,0\right)$

De drie maten van PW zijn uiet onafhankelijk van elkaar (zie tabel 8.2). Met name bestat er een significant negatief verband tussen de STAB en de INFR maat $(r=$ $-33^{* *}$ ): bij hogere stabiliteit van het team wordt cen lagere instroomfrequentie van 
nieuwe medewerkers angetrofen. Voor een overzicht van de intercorrelaties tussen alle variabelen wordt verwezen natabel $B 8.5$.

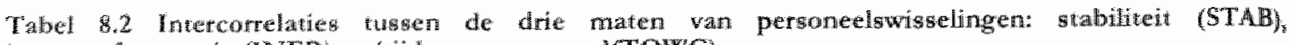

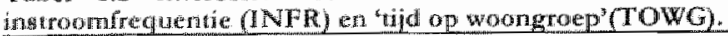

\begin{tabular}{|c|c|c|c|}
\hline Misar & $3 \mathrm{TAB}$ & INRR & TOWG \\
\hline STAB & 100 & & \\
\hline DEll & -3.3 & 1.00 & \\
\hline TOWW & 19 & .06 & 1.00 \\
\hline
\end{tabular}

Uiteraard ligt de correlatie tussen STAB en INFR in de lijn van de verwachtingen maar de grootte van de gezamenlijke variantie - ongeveer 10 procent - is van dien aard dat aangenomen mag worden dat her toch gaat om twee verschillende modaliteiten van PW. Tussen STAB en TOWG bestaat een significante correlatie van $\mathrm{r}=.19 *$ : in meer stabiele teams worden hogere uitkomsten op de TOWG maat gevonden. Op zichzelf ligt ook dit in de lijn van de verwachtingen maar hier geldt nog duidelijker dat de twee maten verschillende modaliteiten van personeelswisselingen vertegenwoordigen. Om een beeld te krijgen van de 'zuivere' correlaties tussen twee variabelen (wanneer gecontroleerd wordt voor de derde variabele), werden partiële correlaties berekend. De partiële correlatie tussen STAB en INFR, controlerend voor TOWG, bedraagt $r=-35^{* *}$; tussen STAB en TOWG, controlerend voot INFR bedraagt de partiële correlatie $r=.22^{* *}$; nussen TOWG en INFR, controlerend voor STAB is de partiele correlatie $1=.13$. Dit ligt in dezelfde lijn als de uitkomsten in tabel 8.2. De drie PW maten zullen - zoals voorgenomen - in de analyses daarom consequent afzonderlijk worden gehanteerd.

\subsection{Onderzoeksvraag 1: verband tussen personeelswisselingen en woongroepkenmerken}

Onderwocksvraag 1 luidt: Is or een werband thossen personzelswisselingen en organisatiokenmerken?' "Tot deze onderzoekswrang behoren vijf deelvragen. Hiema worden de uitkomsten vermeld per deelvrang voor elke maat van personeelswisselingen (PW) afronderijik (STAB, INER en TOWG).

- Declvaag 1.1: Wat is het verband tussen de omvang van PW en de factor "instelling?

Deze vaag beantwootden door te kijken nar de verschillen in PW tussen de instellingen $A, B, C, D$, en $E$. In tabel 8.1 staan de uitslagen op de drie maten van personcelswisselingen per instelling. De uitkomsten van de ANOVA toets van de verschillen staan in tabel 8.3 .

De verschillen tussen de instellingen op de STAB mat zijn niet significant. De instellingen verschillen onderling wèl significant op de INFR en de TOWG maat. 
De $\eta^{2}$ waarde is een maat voor de associatie tussen afhankelijke en onafhankelijke variabele en geeft de proportie van de variantie van de afhankelijke variabele (in dit geval, PW-maten) die wordt verklaard door de verschillen tussen de groepen (in dit geval, de instellingen). De instroomfrequentie is nauw gerelateerd aan het vervangingsbeleid van de instelling; hierin blijken de instellingen van elkaar te verschillen (zie paragraaf $3.2 .3-2$ ).

Tabel 8.3 ANOWA toets van de verschillen tussen de vijf instellingen (188 woongropen) voor de personeelswisselingmaten stabiliteit (STAB), instroomfrequentie (NVR) en "tijd op woongroep" (TOWG)

\begin{tabular}{|c|c|c|c|c|}
\hline malat & $d f$ & $\mathbb{E}$ & $y^{2}$ & $\mathrm{p}$ \\
\hline$S T A B$ & 4 & 2,211 & .06 & .070 \\
\hline MNAR & 4 & 9,837 & .18 & $.000 * * 1$ \\
\hline TOWG & 4 & $14.89 ?$ & .26 & .000 \\
\hline
\end{tabular}

Nadere analyse (tabel B8.4) geeft een indicatie van negatieve samenhang van de stabiliteit met het verloop in de instelling (Spearman's $\varrho=-.90 *$ ): in instellingen met lager verloop blijkt de stabiliteit van de woongroepteams hoger. Dit verband is er niet met de andere maten van personeelswisselingen. Er is geen significant verband tussen de gemiddelde personeelswisselingen in de vijf instellingen en het ziekteverzuim.

- Deelvraag 1.2: Is er een verband tussen de omvang van PW en de grootte van clusters van woongroepen (CLUS)?

Tabel 8.4 Frequentieverdeling van woongroepen naar clusteromvang per instelling en totaal

\begin{tabular}{|c|c|c|c|c|c|c|}
\hline \multirow[b]{2}{*}{ Custeromwang } & \multicolumn{5}{|c|}{ Instelling } & \multirow[b]{2}{*}{ Tоเมа } \\
\hline & A & $B$ & C & $\mathrm{D}$ & $E$ & \\
\hline l & & 1 & & 3 & & 4 \\
\hline 2 & & 2 & 4 & 26 & & 32 \\
\hline 3 & 6 & 3 & 2 & 9 & & 20 \\
\hline 4 & & & 12 & & & 12 \\
\hline 5 & 10 & & 8 & & & 18 \\
\hline 6 & & 12 & & & & 12 \\
\hline 7 & 17 & & 6 & & & 23 \\
\hline s & 7 & 6 & & & & 13 \\
\hline 12 & & 9 & & & 11 & 20 \\
\hline 14 & & & & & 14 & $14 \mathbb{1}$ \\
\hline 20 & & & & & 20 & 20 \\
\hline Totall asntal & 40 & 33 & 32 & 38 & 45 & 188 \\
\hline
\end{tabular}

In het onderzoek zijn de gegevens van 188 woongroepen opgenomen. Vier woongroepen staan op zichzelf; de andere maken deel uit van clusters. De gemiddelde omvang van een cluster bedraagt $\mathrm{M}=7,7$ woongroepen $(S \mathrm{D}=5,8)$. De verdeling van woongtoepen over clusters per instelling staat in tabel 8.4. De correlatie tussen clustergrootte en de drie maten van personeelswisselingen staan in tabel 8.5 . 


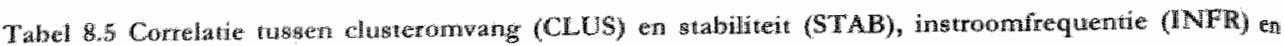

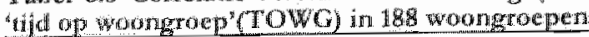

\begin{tabular}{|c|c|c|c|}
\hline & STAB & $\mathrm{NHR}$ & $\mathrm{TOMG}$ \\
\hline CLUS & $16 w^{\prime \prime \prime}$ & $-28^{* * *}$ & $-41^{* i}$ \\
\hline
\end{tabular}

Er bestaat een significant verband tussen de omvang van clusters van woongroepen en personeelswisselingen. In woongroepen die behoren tot een groter cluster is de stabiliteit significant lets groter $\left(r=.16^{*}\right)$ maar er is nog duidelijker een significant lagere instroom van 'nieuwe gezichten' $\left(r=-28^{* *}\right)$. De correlatie tussen clustergrootte en de 'rijd op woongroep' van groepsleiders is in de verzameling woongroepen van de viff instellingen negatief. Dit laatste hangt slechts gedeeitelijk samen met de lagere gemiddelde TOWG waarden in instelling $\mathrm{E}$, gepaard met de grote clusteromvang in deze instelling (tabel 8.1 en tabel 8.4). Met weglating van instelling E bedraagt de correlatie tussen TOWG en de clusteromvang $r=-30 * *$ terwijl de correlatie tussen INFR en clusteromvang dan $\mathrm{r}=-.36^{* *}$ bedraagt.

- Deelvraag 1.3: Is er een verband tussen de omvang van PW en de situering van woongroepen op, respectievelijk buiten het terrein (SOC)?

Deze vraag wordt beantwoord door te kijken naar de verschillen in PW van woongroepen op, respectievelijk buiten het terrein? Er zijn 97 woongroepen op het instellingsterrein en 91 woongtoepen buiten het instellingstertein. De verdeling per instelling staat in tabel 8.6 .

Tabel 8.6 Frequentievendeling vart woongroepen op, respectievelijk buten het instellingsterrein (sociowoningen) per instelling en total

\begin{tabular}{|c|c|c|c|c|c|c|}
\hline \multirow[b]{2}{*}{ Worningert } & \multicolumn{6}{|c|}{ Irustelling } \\
\hline & A & $B$ & $\mathrm{C}$ & $D$ & 5 & Total \\
\hline Op revetu & 27 & 18 & 23 & 29 & 0 & 97 \\
\hline Buten terroin & 13 & 15 & 9 & 9 & 45 & 91 \\
\hline "Totatal & 40 & 33 & 32 & 38 & 4.5 & 188 \\
\hline
\end{tabular}

Er is geen verschil tussen het kenmerk 'op het terrein' en 'buiten het terrein' (sociowoning) wat betreft de frequentie van instroom van nieuwe medewerkers (INFR). In woningen op het terrein is de gemiddelde stabiliteit (STAB waarde) 63,2 tegen 70,4 in sociowoningen; dit verschil is wel significant. De TOW/G warden bedragen 34,2 maanden in sociowoningen tegen 51,2 maanden in woongroepen op het terrein; ook dit verschil is significant (tabel 8.7).

In termen van correlatie is er cen klein positief verband tussen het kenmerk sociowoning en de stabiliteit wan het team $\left(\mathrm{r}=.17^{*}\right)$ en een negatief verband $(\mathrm{r}=$ $-30^{* *}$ ) met TOWG (tabel B.8.5). Voor de interpretatic van de lagere TOWG waarden in sociowoningen moet erop gewezen worden dat sociowoningen gemiddeld kotter bestaan dan woongroepen op het terrein; door het deconcentratiebeleid van instellingen zijn recent juist veel sociowoningen gecteëerd (zie ook de bespreking van "interacties", na deelvraag 1.5 ). 


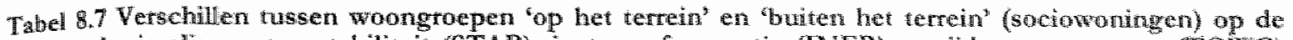
personeelswisselingmaten stabiliteit (STAB), instroomfrequentie (TNFR) en wij op woongroep (TOWG) $N=188)$.

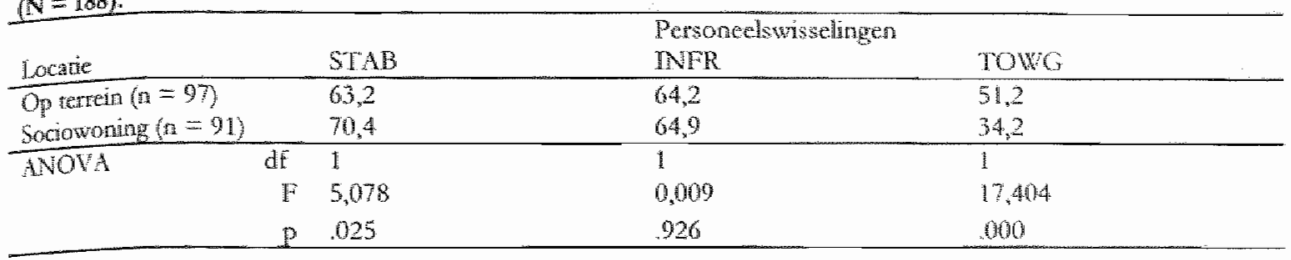

- Deelvraag 1.4: Is et een verband tussen PW en de grootte wan woongtoepen (NBEW)?

De frequentieverdeling van de woongtoepen naar grootte en instelling staat in tabel 8.8 .

De gemiddelde grootte van de woongroepen bedragt 8,5 bewoners (bereik: van 3 tot 14 bewoners; $\mathrm{SD}=2,9$ ). De gemiddelde omvang van een woongroepteam bedraagt 9,0 medewerkers $(\mathrm{SD}=3,2)$.

Tabel 8.8 Frequentieverdeling van woongroepgrootte (aantal bewoners), geniddelde (M) en standararddeviatie woongroepgrootte (SD) per instelling

\begin{tabular}{|c|c|c|c|c|c|c|}
\hline \multirow[b]{2}{*}{$\begin{array}{l}\text { Aantal } \\
\text { bewroncess }\end{array}$} & \multicolumn{6}{|c|}{ Instelling } \\
\hline & $A$ & $B$ & C & $\mathrm{D}$ & 1 & "Total \\
\hline 3 & & & 2 & & $\mathbb{H}$ & 3 \\
\hline 4 & 1 & 1 & 2 & 3 & 5 & 12 \\
\hline 5 & 3 & & 1 & & 9 & 13 \\
\hline 6 & 12 & 4 & & & 12 & 28 \\
\hline 7 & 5 & 2 & 1 & 2 & 9 & 19) \\
\hline 8 & 6 & 7 & 3 & 4 & 6 & 26 \\
\hline 9 & 3 & 2 & 2 & 5 & 1 & 13 \\
\hline 10 & 1 & 4 & 8 & 5 & $\mathbb{1}$ & 19 \\
\hline $\mathbb{H}$ & 2 & 4 & 7 & 3 & & 16 \\
\hline 12 & 3 & 6 & 5 & 6 & & 20 \\
\hline 1.3 & 3 & 1 & $j$ & 10 & & 15 \\
\hline 14 & $\mathbb{1}$ & 2 & & & $\mathbb{1}$ & 4 \\
\hline$M$ & 80 & 9,5 & 9,3 & 10.2 & 6,3 & 8,5 \\
\hline$\$ \mathrm{D}$ & 2,7 & 2,6 & 2.8 & 2,7 & 1.8 & 2,0 \\
\hline Tolmal & 40 & 33 & 32 & 38 & 45 & 188 \\
\hline
\end{tabular}

De instellingen verschillen onderling significant wat betreft gemiddelde groepsgrootte (ANOVA: $\mathrm{df}=4 ; \mathrm{F}=15,494 ; \mathrm{p}=.000$ ***). Tabel 8.9 lat geen verband zien tussen stabiliteit en de woongroepgrootte. Hetzelfde geldt voor instroomfrequentie en woongroepgrootte. Er is wel een significante correlatie tussen woongroepgrootte en de 'tijd op woongrop' maat: in grotere woongroepen maken groepsileiders gemiddeld langet deel uit van het team.

Tabel 8.9 Correlative tussen woongroepgrootte (NBEW) en stabiliteil (STAB), instroomfrequentic (INFR) en "tijd op woongroep' (TOWG) in 188 woongroepen

\begin{tabular}{cccc}
\hline & MHA & MNR & TOWG \\
\hline NBEW & -.03 & .03 & $.35^{4 *}$ \\
\hline
\end{tabular}




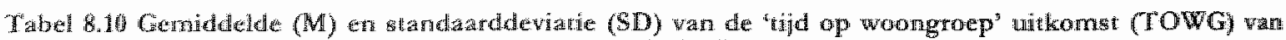
geconitasterde "grote" en "Wleine" wowngropgroote (NBEW)

\begin{tabular}{|c|c|c|c|c|}
\hline \multirow[b]{2}{*}{ Orrvontay } & \multicolumn{2}{|c|}{ Mefreving } & \multicolumn{2}{|c|}{$\mathrm{TONG}_{3}$} \\
\hline & $M$ & 50 & $M$ & SD \\
\hline "kein" & 6,2 & 1.4 & 33,5 & 24,5 \\
\hline "yncotut" & 11,2 & 1.5 & 54,2 & 28,7 \\
\hline
\end{tabular}

Opsplitsing van alle woongroepen waarvan TOWG waarden beschikbaar zijn $(\mathrm{N}=$ 180 ) in twee categorieën ('klein' versus 'groot' volgens het criterium 'beneden' of 'boven' gemiddelde van alle groepen) geeft als gemiddelde TOWG warden respectievelijk 33,5 maanden en 54,2 maanden (tabel 8.10 ). Dit verschil is significant (ANOVA: df $=1 ; \mathbb{E}=27,280 ; \mathrm{p}=.000^{* *}$ ).

- Deelvraag 1.5: Is er een verband tussen PW en de zorgzwaarte van woongroepen (ZOZW)?

Tabel 8.11 geeft een overzicht van de zorgzwaarte van de woongroepen uit ons onderzoek. De gemiddelde zotgzwaarte van alle woongroepen is 58,9. Dit betekent dat gemiddeld 58,9 procent van de bewoners behoren tot de groep 'ernstig' of 'zeer emstig' verstandelijk gehandicapten. De standaarddeviatie is 36,7. De gemiddelde zorgzwaarte van woongroepen verschilt significant tussen de instellingen (ANOVA: $\mathrm{df}=4 ; \mathrm{F}=4,587 ; \mathrm{p}=.001 * *$ ).

Tabel 8.11 Frequentievetdeling van woungtoepen naar zorgzwaartecategorie per instelling en totaal

\begin{tabular}{|c|c|c|c|c|c|c|}
\hline \multirow[b]{2}{*}{ Zotgewwartecategorie } & \multicolumn{6}{|c|}{ Instelling } \\
\hline & A & B & $\mathrm{C}$ & $D$ & $\mathrm{E}$ & Totail \\
\hline $0-10$ & 7 & 2 & 3 & 15 & 6 & 33 \\
\hline $1:-20$ & 3 & & 2 & 3 & 2 & 10 \\
\hline $21-30$ & 3 & 2 & 1 & 3 & 2 & 11 \\
\hline $311=40$ & 1 & 2 & 3 & 1 & 3 & 10 \\
\hline $411-50$ & 10 & 1 & 3 & 1 & 6 & 21 \\
\hline $51-60$ & & 2 & 2 & & 4 & 8 \\
\hline $61-70$ & 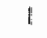 & 3 & & 3 & 2 & 9 \\
\hline $71-80$ & 2 & $\mathbb{1}$ & 4 & 1 & 6 & 14 \\
\hline 8100 & 5 & 5 & 5 & 2 & 6 & 23 \\
\hline $91.4(6)$ & 5 & 15 & 9 & 9 & 8 & 49 \\
\hline 'I (x) & 40 & 33 & 32 & .38 & 45 & 188 \\
\hline
\end{tabular}

Cir is cen klein significant negatief verband tussen zorgzwarte van de woongroep en de instroomfrequentie van nicuwe groepsleiders (tabel 8.12).

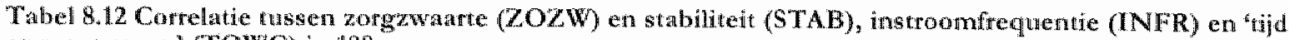
ap woongroep (TOWG) in 188 woong toepen

\begin{tabular}{llll} 
& STIS & TNFR & TOWG \\
\hline $7 O L W$ & -.04 & $-.17^{*}$ & -11 \\
\hline
\end{tabular}

In groepen met grotere zorgzwaarte is de instroom van nieuwe groepsleiders tijdens een jaat lets lager dan in groepen met lagere zorgzwarte. Op de andere maten is er geen verband tussen PW en de zorgzwaarte van woongroepen. 


\section{- Interacties}

In de voorafgaande analyses is gekeken naar het verband tussen elk woongropkenmerk afzonderlijk en personeelswisselingen. Woongroepkenmerken zijtn echter niet onathankelijk van elkaar. Analyse van interacties tussen deze kenmerken stan in tabel B8.6. Hieruit blijken interactie-effecten te bestan van de variabele sociowoning met het aantal bewoners en de zorgzwaarte. Tabel 8.13 toont de verschillen tussen groepen op het tettein en sociowoningen op de kenmerken CLUS, NBEW en ZOZWA; de uitkomsten op de drie PW-maten worden in deze thel hethald.

Tabel 8.13 Verschillen tussen woongroepen 'op het terrein' en 'buiten het terfein' (sociowoningen) voor de. woongroepkenmerken clustergrootre (CLUS), groepsgrootte (NBEW), zorgzawarte (2O2W) en de perstoneelswisselingmaten stabiliteit (STAB), instroomfrequentie (INFR) en tijd op woongroep (TOWG) (N = 1881.

\begin{tabular}{|c|c|c|c|c|c|c|}
\hline \multirow[b]{2}{*}{ Locanie } & \multicolumn{2}{|c|}{ Woongtoephenmert } & \multicolumn{4}{|c|}{ Personcelswisselingen } \\
\hline & CLUS & NBEW & ZOZW & STAB & MNER & IOWO \\
\hline$O_{p}$ terein $(n=97)$ & 4,2 & 10,0 & 69,5 & 63.2 & 64,2 & 51,2 \\
\hline Sociowoning $(\mathrm{n}=91)$ & 11,3 & 7,0 & 44,4 & 70.4 & 649 & 34,2 \\
\hline \multicolumn{7}{|l|}{$\mathrm{NOOH}^{\mathrm{Y}}$} \\
\hline Di & 1 & 1. & 1 & 1 & 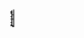 & $\mathbb{1}$ \\
\hline P & 120,413 & 73,370 & 24,991 & 5,078 & 0,009 & 17.404 \\
\hline P & .000 & .000 & .000 & .025 & .920 & 000 \\
\hline
\end{tabular}

Voor de vetbanden tussen woongtoephenmerken en stabiliteit wan het team leiden. deze interacties niet tot andere conclusies over de relatie tussen SOC en STAB. Voor de instroom van nieuwe teamleden en de 'tijd op woongroep'-mat zijn er significante interacties tussen het kenmerk 'sociowoning' en, groepsgrootre en zorgzwaarte. Controlerend voor groepsgrootte respectievelijk voor zorgzwarte leidt niet tot andere relaties tussen SOC en INFR zoals getoond in tabel 8.7 en tabel B8.5. Controlerend voor groepsgrootte is de pattiële correlatie tussen sociowoning en de 'tijd op woongroep'-maat $\mathrm{r}=-.53^{\text {* }}$; ; controletend woor zorgzwarte is deze partiele correlatic $x^{*}=-36^{*}$ " In de praktijk heeft dit ermee te maken dat sociowoningen relatief korter bestan dan wongroepen op het terten, keiner zijn en gemiddeld een lagere zorgzwarte hebben. Zij blijken ook deel wit te malken wan grotere clusters (tabel 8.13 ).

\section{- Samenvating}

Met bovenstaande resultaten kan de eerste onderzoeksvraag als volgt worden beantwoord (tabel 8.14).

Instellingen verschillen onderling niet in de stabiliteit van woongroepteams. Stabiliteit staat nauw in verband met verloop. Instellingen verschillen onderling wel duidelijk op de instroomfrequentie van nieuwe groepsleiders in de woongroeptcams. Ook verschillen ze dudelijk op de 'tijd op wongroep' mat van personcelswisselingen. Grotere clusters van woongroepen gaan gepaatd met grotere stabiliteit van het woongroepteam, en nog duideliker met een lagere instroomfrequentic van 
nieuwe gropsleiders. In grotere clusters verblijven groepsleiders minder lang in de woongroepteams. In sociowoningen wordt een iets grotere stabiliteit aangetroffen, terwil de tijd dat gtocpsleiders werken in teams van sociowoningen korter is. In grotere woongroepen bliken groepsleiders duidelijk langer deel uit te maken van het team. In woongroepen met grotere zorgzwate is er een lagete instroom fan nieuwe medewerkers.

Tabel 8.14 Samenwatting wan de antwoorden op de vijf deelvragen "woongroepkemmerken".

\begin{tabular}{|c|c|c|c|}
\hline \multirow[b]{2}{*}{ Worngroepkentratk } & \multicolumn{3}{|c|}{ Personedswisselingen } \\
\hline & STAB & INFR & TOWWG \\
\hline IVIS & & initiv & is \\
\hline CluS & + & $\ldots$ & -- \\
\hline Soc & \$ & & 央事 \\
\hline NBEW & & & $+t$ \\
\hline $20 Z W$ & & - & \\
\hline
\end{tabular}

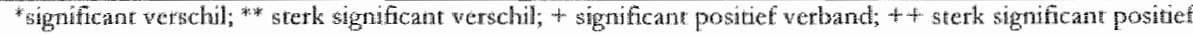
werband; - significant negatief verband; - - sterk significant negathef wetband

\subsection{Onderzoeksvraag 2: verband tussen personeelswisselingen en teameffectiviteit}

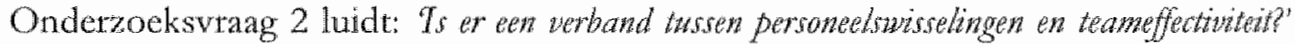
"Tot deze onderzockswrag behoren vier deelvragen. Hierna worden de uitkomsten vermeld per declvaag voor elke maat van personeelswisselingen afzonderlik (STAB, INFR en TOWG).

Tabel 8.15 Gemiddelden (M) en standaatdeviaties (SD) van de uitslagen op de teameffectiviteit wariabelen: atbeidssatisfactie (MAS), rolduidelijkheid (ROL), vertrowwen in eigen doelmatigheid (VER) ef: ervaren autonomic (AUT). Per instelling en woor het total aantal woongroepen $(\mathrm{N}=180)$. ANOVA woor verschillen tussen instellingem.

\begin{tabular}{|c|c|c|c|c|c|}
\hline \multirow[b]{2}{*}{ Instething } & & \multicolumn{4}{|c|}{ Teamfunctioneren } \\
\hline & & MAS & ROI & VER & AUT \\
\hline \multirow[t]{2}{*}{$A$} & $\mathrm{M}$ & 3,57 & 5,40 & 5,76 & 5,17 \\
\hline & SD & 0,24 & 0,30 & 0,58 & 0,66 \\
\hline \multirow[t]{2}{*}{ If } & $\mathrm{M}$ & 3,53 & 5,38 & 5,57 & 5,25 \\
\hline & $S D$ & 0,28 & 0,37 & 0,71 & 0,62 \\
\hline \multirow[t]{2}{*}{ C. } & M & 3,34 & $5,3,3$ & 5,39 & 5,14 \\
\hline & SD & 0,23 & 0,30 & 0,55 & 0,44 \\
\hline \multirow[t]{2}{*}{ D } & $\mathrm{M}$ & 3,62 & 5,70 & 5,77 & 5,20 \\
\hline & SD & 0,24 & 0.23 & 0,49 & 0.46 \\
\hline \multirow[t]{2}{*}{ li } & $\mathrm{M}$ & 3,42 & 5,22 & 5,37 & 5,12 \\
\hline & $\mathrm{SD}$ & 0,21 & 0,33 & 0,67 & 0,40 \\
\hline \multirow[t]{2}{*}{ ligtatal } & $\mathrm{M}$ & 3,50 & 5,41 & 5,58 & 5,18 \\
\hline & $S D$ & 0,26 & 0,35 & 0,61 & 0.53 \\
\hline \multirow[t]{3}{*}{ MNOVA } & $d i$ & 4 & 4 & 4 & 4 \\
\hline & 17 & 7,32 & 12,922 & 3,663 & 0,360 \\
\hline & $\mathrm{P}$ & .000 & .000 & .007 & .837 \\
\hline
\end{tabular}

Nows. MAS betreti cen 5-purt schal. ROL, VER, en AUT betreffen 7-punt schalen

Tabel 8.15 toont de uitkomsten op de vier variabelen met betrekking tot teameffectiviteit in de vijf instellingen en in de totale groep. De verschillen tussen de instellingen zijn significant voor elke variabele behalve voor ervaren autonomie (AUT). 
De vier deelvragen worden beantwoord an de hand wan de uitkomsten in tabel 8.16 .

Tatol 8.16 Comelaties tussen arbeidssatisfactie (MAS), rolduidelikheid (ROL), vertrouxwen in doelmatigheid (VER) en ervaren zutonomie (AUT), en de personeelswisselingmaten stabulitait (STAB), instroomfrequertin (TNFR) en 'tijd op woongroep' (TOWG)

\begin{tabular}{|c|c|c|c|}
\hline \multicolumn{4}{|c|}{ Personeelswisselingern } \\
\hline 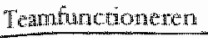 & $S T A B$ & INFR & TOWG \\
\hline $\mathrm{MHS}$ & .03 & -.02 & $.18^{\circ}$ \\
\hline $\mathrm{ROL}$ & -01 & $.15^{*}$ & $34 \%$ \\
\hline WER & .24 & -10 & $25 *$ \\
\hline AUT & $23^{3 * k}$ & -.08 & $16^{\circ}$ \\
\hline
\end{tabular}

- Deelvraag 2.1: Is er een verband tussen PW en arbeidssatisfactie (MAS)?

Er wordt alleen een significant verband gevonden tussen arbeidssatisfactie en de 'tijd op woongroep'. Er is een klein positief verband tussen arbeidssatisfactie en de ajd die groepsleiders deel uimaken van het woongroepteam.

- Deelvraag 2.2: Is er een werband tussen PW en rolduidelijkheid (ROL)?

Er is een klein positief verband tussen rolduidelijkheid en de instroomfrequentie van nieuwe medewerkers in het woongroepteam. Er is een duidelijker en groter verband tussen rolduidelijkheid en de tijd die medewerkers deel uitmaken van het woongroepteam.

- Deelvtaag 2.3: Is er een verband tussen PW en vertrouwen van het team in eigen doelmatigheid (VER)?

Er bestaat een significant positief verband tussen stabiliteit van het team en het vettrouwen van groepsleiders in eigen doelmatigheid. Er bestat eveneens cen significant positief verband tussen de tijd die medewerkers in hetzelfde team functioneren en het door hen geuite vertrouwen in eigen doelmatigheid.

- Deelvrang 2.4: Is er een verband tussen PW en de door de teamleden ervaren autonomie (AUT)?

In teams met een hogere stabiliteit (minder groepsleiders verieten het team in de loop van cen jaar) ervaren de respondenten meer autonomic. Er is geen verband tussen de door teamleden ervaren autonomic en het aantal nicuwe instromers, Er is een klein positief verband tussen ervaren autonomie en de duur van de periode dat gtoepsleiders werkzaam zijn in het team. 


\section{- Samenvatting}

Stabiliteit van het woongroepteam (STAB) vertoont een positief verband met vertrouwen in doematigheid wan het eigen team (VER) en met de door groepsleiders ervaten autonomie in hun werk (AUT). Et is geen verband met arbeidssatisfactie noch met rolduidelinheid.

De nijd die groepsleiders deel uimaken wan hun woongroepteam (TOWG) is positief geassocieerd met elk van de vier effectiviteitmaten; het verband is het sterkst mer roldudelikheid (ROL) en vertrouwen in eigen doelmatigheid (VER).

Instroomfrequentic (INFR) heeft een klein verband met grotere rolduidelikheid van de groepsleiders in het team.

\subsection{Onderzoeksvraag 3: verband tussen personeelswisselingen en door familie ervaren kwaliteit van begeleiding}

Onderzoekswagg 3 luidt: Is er een verbond twsen personelsuisselingen en door fomilie ervaren kewathtait wan begeleiding?' Hititoe honen twee deelvragen.

Tabel 8.17 Gemiddelden (M) en standaarddeviaties (SD) van dle uitslagen op die door familie erwarer kwaliteit wan begeleiding (HARC en CPSQ) per instelling en woor het totad aratal woongroepen $(N=180)$. ANOVA voor verschillen tussen instellingen.

\begin{tabular}{|c|c|c|c|}
\hline \multirow[b]{2}{*}{ Instelling } & & \multicolumn{2}{|c|}{ 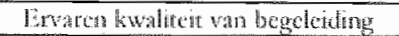 } \\
\hline & & $\mathrm{HARC}$ & $\mathrm{CPSO}$ \\
\hline \multirow[t]{2}{*}{$A$} & $M$ & 5,45 & 5,98 \\
\hline & $5 \mathrm{D}$ & 0,75 & 0,43 \\
\hline \multirow[t]{2}{*}{ B } & $M$ & 5,64 & 5,88 \\
\hline & SD & 0,52 & 0,45 \\
\hline \multirow[t]{2}{*}{ C } & M & 5,21 & 5,61 \\
\hline & $S \mathrm{D}$ & 0,60 & $0,6.3$ \\
\hline \multirow[t]{2}{*}{$D$} & $M$ & 5,67 & 5,97 \\
\hline & $S D$ & 0,20 & 0,38 \\
\hline \multirow[t]{2}{*}{$\mathbb{E}$} & $\mathrm{M}$ & 5,30 & 5,82 \\
\hline & $\mathrm{SD}$ & 0,60 & 0,44 \\
\hline \multirow[t]{2}{*}{ Trutat } & $M$ & 5.47 & 5,86 \\
\hline & $S D$ & 10,61 & 0,48 \\
\hline \multirow[t]{3}{*}{ ANONA } & dif & 4 & 4 \\
\hline & $F^{*}$ & 4,183 & 3,593 \\
\hline & $P^{2}$ & 003 & 01008 \\
\hline
\end{tabular}

Ih tabel 8.17 staan per instelling en voor de totale groep de uitkomsten op de vragenlijston met betrekking tot ervaten inhoudelijke kwaliteit (HARC) respeclievelijk erwaren relationele kwaliteit (CPSQ). Op beide maten zijn de verschillen tussen de instellingen significant.

- Declvaag 3.1: Is er een verband tussen PW en de door familie erwaren inhouddije kwaliteit van begeleiding (HARC)?

Uit tabel 8.18 blijkt een significant positief verband tussen de tijd dat groepsleiders deel uimaken van het team en de door familie ervaren inhoudelijke kwaliteit wan 
begeleiding. Et is geen verband tussen erraren inhoudelike kwaliteit en stabiliteit en instroomfrequentie van groepsleiders in de woongroepen.

Tabel 8.18 Cotrelaties tussen door familie ervaren inbondelijke (HARC) en relationele (CPSQ) kwaliteit wan begeleiding, en de personeelswisselingmaten stabiliteit (STAB), instromfrequente (INFR) en "tijd op? wromgroe $\mathrm{p}(\mathrm{TOW})$

\begin{tabular}{|c|c|c|c|}
\hline \multirow[b]{2}{*}{ Ereaten kwalitet } & \multicolumn{3}{|c|}{ Personcelswiscelingect } \\
\hline & $S T A B$ & DNER & $\mathrm{TCKK}$ \\
\hline $\mathrm{AARC}$ & .14 &.,- 04 & $19 \%$ \\
\hline $\mathrm{CBSO}$ & $.166^{\text {ik }}$ & -12 & $24^{2}$ \\
\hline
\end{tabular}

$N=180$

- Deelvaag 3.2: Is er een verband tussen PW en door familie ervaren relarionele kwaliteit van de begeleiding (CPSQ)?

Uit tabel 8.18 blijt een positief vetband tussen door familic ervaren relationele kwaliteit van begeleiding en de stabiliteit van het woongroepteam. Er is een duidelijk positief verband tussen relationele kwaliteit en de tijd dat groepsleiders deel uitmaken van het woongtoepteam. In teams met hogere gemiddelde dienstuid. wordt een hogere tevredenheid van de familie met de relationcle aspecten van de begeleiding aangetroffen.

Omdar beide kwalliteitsmaten niet onafhankelijk zijn (er is een intercorrelatie wan $\mathrm{t}^{\circ}$ $=.66^{*}$, zie tabel B.8.5) werd ook de partiele correlatie berekend tussen CPSQ an TOWG, controlerend voot $\mathrm{STAB}$; in dat geval is de cortelatie $r=21 * *$. De significante correlatie tussen HARC en TOWG verdwijnt echter wanneer word gecontroleerd voor CPSQ $(r=.05)$. Er is een duiclelik verband tussen CPSQ en 'TOWG. Omdat ook de twee personeelswisselingmaten STAB en TOWG niet onafhankelijk zijn (er is een intercomelatie van $\mathrm{r}=.19 \%$ ) werd onderzocht of de significante correlatie tussen CPSQ en STAB stand houdt bij controle voot TOWG. Dit is niet het geval; de cortelatie tussen CPSQ en STAB zakt dan van $r=.16$ wat $r=.12$ en is niet significant $(\mathrm{p}=.13)$.

De maat 'ijd op woongroep' blijkt de duidelijkste samenhang te vertonen met door Eamilie ervaren (relationele) kwaliteit van begeleiding.

\section{- Samenvatring}

Het antwoond op onderzoeksvraag 3 luidt dat er en duidelijk positief verband bestat tussen door familye ervaren relationele kwaliteit van begeleiding en de thj dar groepsleiders deel uitmaken wan het woongroepteam. Fr is cen kielin positicf verband tussen door familie ervaren inhoudelike kwalireit van begeieiding on de tijd dat groepsleiders deel uitmaken van het woongroepteam. 


\subsection{Onderzocksvaag 4: verband tussen teamfunctioneren en door familie ervaren kwaliteit van begeleiding}

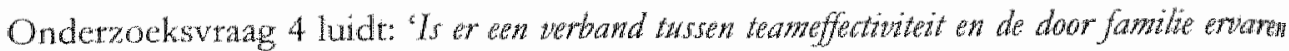
kwaliteit wan begeleiding?" Het spiegeleffect zoals beschreven door Hesket, Sasser en Schlesinger L.A. (1997) voorspelt een verband tussen arbeidssatisfactic van mede werkers en de kwaliteit van door cliënten ervaren dienstverlening. In hoofdstuk 6 zagen we dat onderzoek van Hartine en Ferrell (1996) en van Wetzels (1998) ook een verband latat zien tussen enerzijds de teamvariabelen rolduidelitheid (ROL), vertrouwen in eigen doelmatigheid VER) en ervaren autonomie (AUT) en anderzijds clicnttevedenheid. Daarop werd onderzoeksvraag 4 gebaseerd. De vier bir horende deelvragen worden hierna behandelcl.

- Deelvragg 4.1: Is er cen verband tussen enerzijds door groepsleiders ervaren arbeidssatisfactie (MAS) en anderzids door familie ervaren kwaliteit van inhoudelike en telationele begeleiding (HARC en CPSQ)?

Op grond van tabel 8.19 kan ecn verband angenomen worden tussen arbeidssatisfactie (MAS) en zowel de inhoudelijke $\left(r=.18^{*}\right)$ als de relationele component $\left(\mathrm{r}=.27^{* *}\right)$ wan door familie ervaren kwaliteit van begeleiding. Het verband is duidelijker en groter met de relationele aspecten van ervaren kwaliteit. Het spiegeleffect wordt in de data van ons onderzoek dus teruggevonden, zij het dat de omvang van het verband met ongeveer 7 procent gemeenschappelijk verklaarde vatiantic, relatief bescheiden is

Tabel 8.19 Correlaties tussen door familie ervaren kwaliteit van begreleiding (HARC en CPSQ) en arbeidssatisfactie (MAS) inclusief de factoronderdelen van de MAS-GZ $(\mathrm{N}=180$ )

\begin{tabular}{|c|c|c|}
\hline \multirow[b]{2}{*}{ Abeidssatisfactie } & \multicolumn{2}{|c|}{ Ervarti kwalireit } \\
\hline & HARC & $\operatorname{CPSO}$ \\
\hline MAS (cotaal) & $.18^{*}$ & $.27^{* 4 k}$ \\
\hline MAS-CY facetren & & \\
\hline$|A|$ & $.224:$ & $.25 \%$ \\
\hline $\mathrm{I}^{\mathrm{M} O}$ & 01 & .14 \\
\hline$K W A$ & .04 & . 198 \\
\hline $\mathrm{COH}$ & 09 & 13 \\
\hline CH & $.1 .55^{\prime \prime}$ & 16 \\
\hline CON & 12 & $24^{x+7}$ \\
\hline DUI & $.19 *$ & $.26^{1+4 *}$ \\
\hline
\end{tabular}

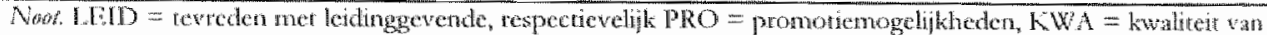

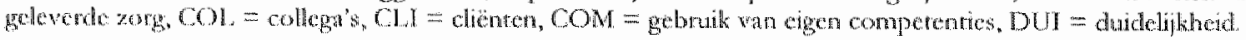

Nadere analyse van de schaalonderdelen van de MAS - zoals besproken in paragraf 7.4 .3 - laat zien dat het verband bestaat tussen ervaren inhoudelike kwaliteit (HARC) en tevredenheid met leidinggevende (LEID) het duidelijkst is. Met ervaren relationele kwaliteit (CPSQ) bestat de duidelijkste relatie met het facet 'tevredenheid met leidinggevende' (LEID). Een dergelijk verband is er ook met de facetten 'tevredenheid met gebruik van eigen competenties' (COM) en 'duidelijkheid' (DUT). Het verband tussen door familie ervaren kwaliteit en arbeids- 
satisfactie wordt niet gemodereerd door de factoren clustergrootte, zorgzwante of groepsgrootte.

In woongroepen met grotere arbeidssatisfactie van groepsleiders wordt significant een grotere tevredenheid van door familie ervaren kwaliteit van begeleiding aangetroffen. Het verband is het sterkst voor ervaren kwaliteit van relationele aspecten van de begeleiding $\left(\mathrm{r}=.27^{* *}\right)$ en is het duidejijkst bij groepsleiders die meer tevreden zijn met hun leidinggevende $\left(r=.25^{*} *\right)$, met gebruik van eigen competenties $(r=.24 * *)$, en met de door hen ervaren duidelijkheid in het werk $(r=.26 * *)$.

- Deelvraag 4.2: Is er een verband tussen enerzijds door groepsleiders ervaren rolduidelijkheid (ROL) en anderzijds door familie ervaren inhoudelijke en relationele kwaliteit van begeleiding HARC en CPSQ?

Op grond van de gegevens uit tabel $8.20 \mathrm{kan}$ worden geconcludeerd dat er een duidelijke cortelatie bestaat tussen rolduidelijkheid en ervaten inhoudelijke ( $r=$ $.21^{* * *}$ ) kwaliteit van begeleiding. Er wordt ook een verband gevonden met door familie ervaren relationele kwaliteit van begeleiding $\left(r=.17^{*}\right)$.

Tabel 8.20 Correlaties tussen door familie ervaren kwaliteit wan begelleiding (HARC en CPSQ) en effectiviteitaspecten van teamfunctioneren, rolduidelijkheid (ROL), vertrouwen in doelmatigheid (VEE) en arvaren atonomic $(A U T)(N=180)$

\begin{tabular}{lll} 
& \multicolumn{2}{c}{ Erwaren kwalitei } \\
\cline { 2 - 3 } reanfunctioneren & HARC & CPSO \\
\hline ROL & $.21^{* *}$ & $17^{*}$ \\
VER & .06 & $.17^{*}$ \\
$M U T$ & $.13^{*}$ & $.18^{*}$ \\
\hline
\end{tabular}

- Deelvraag 4.3: Is er een verband tussen enerzijds door groepsleiders ervaren vertrouwen in doelmatigheid (VER) en anderzijds door familie ervaren inhoudelijke en relationele kwaliteit van begeleiding HARC en CPSQ?

Dit verband wordt op grond var tabel 8.20 alleen aangetroffen met de relationcle kwaliteit van begeleiding $\left(r=.17^{*}\right)$.

- Declvraag 4.4: Is er een verband tussen enerzijds door groepsleiders ervaren autonomie (AUT) en anderzijds door familie ervaren inhoudelijke en relationele kwaliteit van begeleiding HARC en CPSQ?

Tabel 8.20 toont positieve mar bescheiden correlaties voor beide kwaliteitsaspecten: er is sprake van een verband.

\section{- Samenvatting}

Onderzoeksvraag $4 \mathrm{kan}$ als volgt worden beantwoord. Het spiegeleffect tussen arbeidssatisfactie van dienstverleners en door cliënten ervaren kwaliteit wordt in de data teruggevonden, zij het dat het verband klein is en dat het het duidelijkst is voor 
de rulationcle aspecten van ervaten kwaliteit. Dit spiegeleffect kan ook worden geconstaterd tussen door de familie ervaren inhoudelike kwaliteit (HARQ) en roldudelifheid ROL $\left(r=.21 *\right.$ respectievelijk AUT $\left(r=.15^{*}\right)$, en tussen door famile erwaren telationde kwaliteit (CPSQ) en roldudelikheid (17*), tespectievelijl vertrouwen in doelmatigheid $(.17 \%)$, en ervaren autonomie $(\mathrm{r}=.18 *$. De cortelaties zin klein.

\subsection{Onderzoeksvraag 5: personeelswisselingen en het verband tussen teameffectiviteit en door familie ervaren kwaliteit van begeleiding}

Onderzoeksvtaag 5 luidt: 'Spelen personelswisselingen een rol bij bet werband ixsew teaneffertivitut on de dow bet dientsystem erwanen kwaliteit wan begelending?" Onderzocht wordt of personeelswisselingen een moderatot zijn wan het gevonden spiegeleffect: treedt het spiegeleffect even duidelijk en even groot op onder omstandigheden van hoge of lage personeelswisselingen? Met andere woorden, er zal worden nagegan of er interactiemeffecten bestaan tussen personeelswisselingen en de vier effectiviteitaspecten vat teamfunctioneren bij het voorspellen van ervaren kwaliteit van begeleiding. De algemene rorm van deze analyse is:

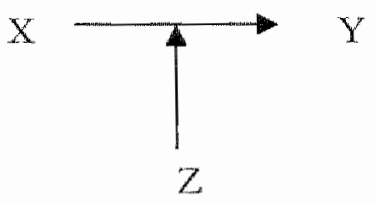

Waarin $\mathrm{Y}$ de critetium wariabele van ervaren kwaliteit is (HARC of CPSQ); $\mathrm{X}$ achterenvolgens elke variabele van teamfunctioneren zal zijn (MAS, ROL, VER, AUT); en Z de moderator vatiabele petsoneelswisselingen (STAB, INER en TOWG) zal zijn. Indicaties voot interacties worden berekend voor XZ (Baron \& Kenty, 1983, p. 1175; Cohen \& Cohen, 1983). De resultaten van de regressieanalyses stan in rabel 13.8 .7 .

Naast deze werkwijze werd het totale bereik van de uitkomsten van elke PW maat opgesplitst in vier groepen (quartielen) voor visuele inspectic van modevatoreffecten. Vervolgens werden de correlaties tussen HARQ respectievelitk CPSO en MAS, ROL, VER en AUT binnen elk quartiel afzonderlik berekend. Op deze wijze wordt gekeken naar het verband tussen de variabelen teamfunctioneren en de exwaren kwaliteit van begeleiding in verschillende bereiken wan $P W$. Indien pW geen rol speelt zal het verband binnen de rerschillende quartielen niet van ellkar verschilcen. De uitkomst van deze procedure staat in de tabellen $B 8.8 ; B 8.9$ en $B 8.10$.

Voor beide procedures geldt de ammame van een lineair verband tussen de betrokken variabelen. 
Uit de regressieanalyse komen twee significante moderatoreffecten naar voren. In de eerste plaats modereert de interactie tussen arbeidssatisfactie en stabiliteir negatief het verband tussen arbeidssatisfactie van groepsleiders en door familie ervaren tevredenheid met relationele kwaliteiten van de begeleiding. Bij lage waarden van stabiliteit (er zijn dan in de loop van het afgelopen jaar veel gropsleiders uit het team vertrokken) is er een sterk positief verband (spiegeleffect) tussen arbeidssatisfactie en ervaren kwaliteit: lage arbeidssatisfactie bij medewerkers gaat in dat geval sterker gepaard met lage tevredenheid met de doot familie ervaren kwaliteit. Het omgekeerde geldt ook: als de arbeidssatisfactie hoog is, is in die situatie ook de tevredenheid van familie ook groot. Bij hoge stabiliteit is er geen verband tussen arbeidssatisfactie en tevredenheid van de familie. Dit wordt geillustreerd door de cijfers in tabel B8.8 waar in het laagste quartiel van STAB cen correlatie van $r=.45^{* *}$ wordt gevonden tussen MAS en CPSQ en in her hoogste quartiel de correlatie nagenoeg afwezig is. Dit effect is ook te zien in tabel B8.9 bij de hoge waarde van INFR, hoewel dit niet blijkt uit de regressie analyse.

In de tweede plaats heeft de interactie tussen stabiliteit en rolduidelijkheid op vergelijkbare wijze een negatief moderatoreffect op het verband tussen rolduidelijkheid van groepsleiders en door familie ervaren tevredenheid met de relationele kwaliteit van de begeleiding. Lage stabiliteit van het woongroepteam in samenhang met hoge mate van rolonduidelijkheid van teamleden, gaat gepaard met lage tevredenheid van de familie over de relationele kwaliteit van de begeleiding.

In tabel B8.8 is dit effect zichtbaar waar bij lage wateden van STAB (op zich een ongunstige situatie want veel groepsleiders - gemiddeld 72 procent - zijn de afgelopen 52 weken uit het team vertrokken) een significante correlatie wordt angetroffen tussen de ervaren rolduidelijkheid van de teamleden en de door familie ervaren relationele kwaliteit van zorg.

De andere gegevens uit de tabellen B8.8, B8.9 en B.8.10 zijn mocilijk to interpreteren en suggereren bij de TOWG variabele cen niet-lineair verband. $O \mathrm{p}$ basis van de resultaten van de regtessicanallyses uit tabel $B 8.7$ is de conclusic gerechtvaardigd dat het spiegeleffect 'onder ongunstige omstandigheden van personeelswisselingen' (lage stabiliteit) sterker optreedt dan onder 'gunstige' omstandigheden.

\section{- Samenvatting}

Het antwoord op de vijfde onderzoeksvrang luidt bevestigend. Met name de omvang van de stabiliteit van thet woongroepteam heeft een negatief effect op de relatie tussen enerzijds de factoren arbeidssatisfactie en rolduidelijkheid van het teamfunctioneten en andetzijds de door het clientsysteem ervaren relationele kwaliteit van begeleiding. Onder ongunstige omstandigheden van stabiliteit (een groot antal groepsleiders verlaten het woongroepteam in de loop van her jaar) 
wordt cen groter verband gezicn russen zowel arbeidssatsfactie en rolduidelikheid in het team en de door familie ervaren kwaliteit van begeleiding.

\subsection{Onderzoeksvraag 6: bijdrage van de gecombineerde variabelen organisatiekenmerken, personeelswisselingen en teameffectiviteit aan de voorspelling van 'ervaren kwaliteit van begeleiding'}

Onderzocksvraag 6 luidt: 'Kan en madel worden opgesteld wan de samenhang iwsen (1) woongrophenwerken, (2) personedswiselingen en (3) teameffectinteit als poorspellers wan de door familie ervaren inboudelijke (HARC) en relatiowele (CPSQ) kwatiteit nan begeleiding?'

De variabelen HARC (inhoudelijke kwaliteit) en CPSQ (relationele kwaliteit) worden afzonderlijk gebruikt als criterium voor het voorspellen van ervaren kwaliteit wan begeleiding. Hiertoe werd een pad analyse uitgevoerd (Ioehlin, 1998).

Een merhodologische opmerking is hier vooraf op zijn plaats. In de analyse van de samenhang wordt geen rekening gehouden met de hiëratchische structuur van de data: de teams hoten immers bij clusters, die op hun beurt binnen instellingen zijn gesitueerd. De teams zijn daarmee niet onafhankelijk van elkaar. In tegenstelling tot regressic-analyse houdt multilevel analyse wel rekening met de hiërarchische structuur van de data. Om eventuele effecten van de hiërarchische datastructuur te verdisconteren werd met dezelfde variabelen een multilevel regressie uitgevoerd (Goldstein, 1995; Woodhouse, 1996). Bij een sterke clustering van teams binnen organisatieclusters en van organisatieclusters binnen instellingen, is multilevel analyse een meer aangewezen benadering, maar leidt vaak ook tot een hogere schatting van de standaardfouten, waardoor effecten minder snel statistisch significant worden. De resultaten van de multilevel analyse staan in tabel B8.11. Hienit blijkt dat 92 procent van de variantic van de HARC variabele op het teamniveau ligt en (slechts) drie, respectievelijk 5 procent op cluster-, respectievelijk op instellingsniveau. Beide laatste percentages zijn niet significant. Bij de CPSQ variabele blijkt 86 procent van de variantie op teamniveau te liggen, en negen respectievelijk 5 procent op cluster-en instellingsniveau. Beide laatste percentages zijn niet significant. Met de kanttekening dat er mogelijk te weinig instellingen en clusters zijn betrokken in het onderzoek, mag geconcludeerd worden dat een multilevel analyse niet geindiceerd is en niet zou leiden tot substantieel andere bevindingen dan hier gerapporteed.

Met pad analyse wordt gezocht naar het empirische verband tussen alle variabelen van de organisatiekenmetken (A), de personeelswisselingen (PW) en van teamfunctioneren (B) als voorspellers van de ervaren kwaliteit van begeleiding. Daarbil werd de werkwijze van Hatton et al. (1999) en Hatton et al. (2001) gevolgd. 
Organisatieken-

nerken

- Insteling

- Custergantre

- Sociowoning of

tertemgebonden

woongropep

- Graotre

woongrodp

- Zorgzwarte

(A)

\begin{tabular}{|c|}
\hline $\begin{array}{l}\text { Personeelswisselin- } \\
\text { gen } \\
\text { - (1) Stabiliteir } \\
\text { - (II) Instroom- } \\
\text { frequendie } \\
\text { - (11)Tijd op } \\
\text { woongroep }\end{array}$ \\
\hline (PW) \\
\hline
\end{tabular}

Erwaren kwalitert wn begeleiding (famille)

- Finwaten bow tived (rechnisch/ inhoudeligk)

- Ervgren kwaliteir functioned/ retationes)

(C)

Figur 8.1 Rankschikking watabelen in wolgonde van veronderstelde invloed op door familie ervaren Lawaliteir:

In een eerste stap werden drie groepen van woorspellers opgesteld; dit zijn de variabelen van het theoretisch kader waarbij in figuur 8.1 de volgotde wan veronderstelde samenhang wordt getoond bij de voorspelling van door familie ervaren kwaliteit. De eerste groep zijn de woongroepkenmerken, de tweede groep zijn de personeelswisselingmaten, de derde groep zijn de effectiviteitaspecten van het teamfunctioneren, en de te voorspellen variabele is de door familie ervaren kwaliteit van begeleiding. Vervolgens werd een multipele regressie analyse uitgevoerd op het criterium 'ervaren kwaliteit van begeleiding'. Alleen variabelen met significante gestandaardiseerde regressiecoëfficiënten ( $\beta$ ) worden behouden als relevant pad. Vervolgens wordt onderzocht in hoeverte deze significante variabelen zelf verklaard kumnen worden vanuit antecedente variabelen. Deze analyse leverde voor de afhankelike variabele "inhoudelijke kwaliteit van begeleiding" (HARC) in de eerste regressie analyse geen enkele significante $\beta$-coëfficiènt op (tabel B.8.12); deze variant wordt daarom niet besproken.

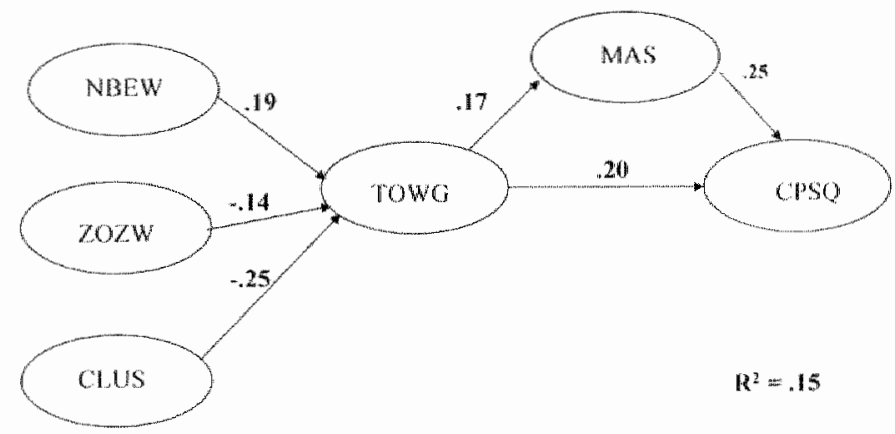

Piguur 8.2 Pad diagram mei voorspellers wan doot familie ervaren relationele kwaliteil van begeleiding (CPSQ)

De uitkomsten van de multipele regressie analyse met "relationele kwaliteit van begeleiding' (CPSQ) staan in tabel B8.13. De visualisering van de gevonden verbanden staat in figuur 8.2. Bij deze untkomsten moet worden aangetekend dat or een telatief sterk verband wordt aangetroffen tussen clustergrootte en de te voor- 
spellen ahankelike variabele "relatonele kwaliteit' $\beta=.213)$. De p-warade van dit verband ligt net boven het $\alpha$-niveau van 5 procent $(\mathrm{p}=.067)$. Het positieve verband tussen clustergrootre en door familie ervaren relationele kwaliteit van begeleiding - binnen de constellatic van de gezamenlike variabelen - is opmerkelijk omdat tussen beide afzonderlik geen correlatie wet gevonden (tabel B8.5). Met de antekcning dat het her om een marginal significant verband gaat wordt dit resultat indicatief weergegeven in figuur B8.1.

De met het pad model totaal verklaarde variantie van door familie ervaten relationele kwaliteit van begeleiding, bedragt 15 procent.

Samenvattend luict het anwoord op onderzoeksvragg 6 dat de door familie ervaren telationele kwaliteit van begeleiding het best word voorspeld door een combinate van (1) arbeidssatisfactie, (2) 'tijd op woongroep', (3) grootte woongroep, (4) zorgzwarte en (5) clustergrootte, zoals getoond in figuur 8.2. Er moet daarbij worden angekend dat ook een ditect verband tussen clustergrootte en de uitkomstraria bele CPSQ, op grond van significantic op het niveau $p=.067$, niet mag worden uitgesloten.

\subsection{Samenvatting van de resultaten}

In tabel 8.21 staat een beknopte samenvatting van de in dit hoofdstuk gevonden resultaten. De bespreking van de resultaten wolgt in hoofdstuk 9.

Tabel 8.21 Samenvating van de tesultaten (onderzoeksvragen $1,2,3,4,5,8$, 6 en laijhorende onderzokekdeelwagen)

Thael 8.21a Samenwatting resultaten onderzoeksvingen 1,2 \& 3

\begin{tabular}{|c|c|c|c|}
\hline \multirow[t]{2}{*}{$\begin{array}{l}\text { Ondermonswag } \\
\text { cn declurag }\end{array}$} & \multicolumn{3}{|c|}{$\begin{array}{c}\text { Personedswestingen (PW/) } \\
\text { Moduliteiten / maten }\end{array}$} \\
\hline & Stabthilit: & Instroom fiequentic & Tind op woongrocp \\
\hline \multicolumn{4}{|c|}{ 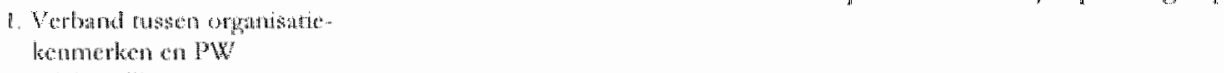 } \\
\hline 1.I Hostetling & & 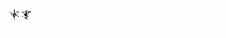 & wh \\
\hline 1.2 Chusictegronoto & + & -- & $-\infty$ \\
\hline 1.3 socioswongeng & : & & $\cdots$ \\
\hline 1.4 Gropesprosthe & & & $\#+$ \\
\hline 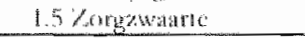 & & $\ldots$ & \\
\hline \multicolumn{4}{|l|}{ 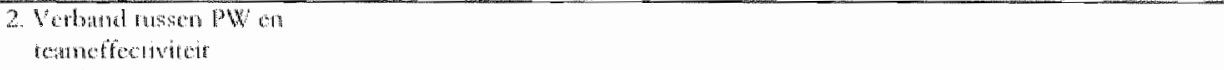 } \\
\hline 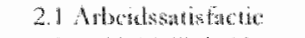 & & & H. \\
\hline 2.2 kstumlelikheid & & + & ++ \\
\hline 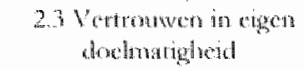 & +4 & & ++ \\
\hline 24 Levaren atomomic & +4 & & + \\
\hline \multicolumn{4}{|c|}{ 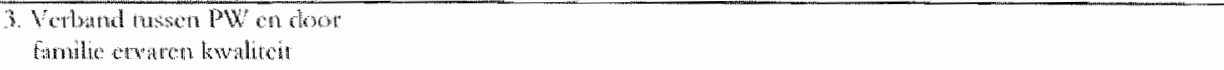 } \\
\hline 3. I inhoudehiflice kwaliod & & & 4 \\
\hline 3.2 relationde kwallate & & & ++ \\
\hline
\end{tabular}


Tabel 8.21 b Samernating resultaten ondlezoeksvigagen 4 \& 5

\begin{tabular}{|c|c|c|}
\hline \multirow{2}{*}{$\begin{array}{l}\text { Onderrokswats } \\
\text { detrrang }\end{array}$} & \multicolumn{2}{|c|}{ Erwen kxwlineit wa begeletding } \\
\hline & Inhoudelik & Relarioned \\
\hline \multicolumn{3}{|c|}{ 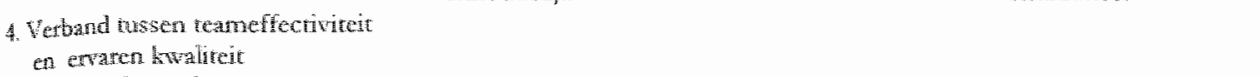 } \\
\hline 4. arbeidssutistactie & + & +4 \\
\hline 42 rolduidelighend & $++\infty$ & +1 \\
\hline 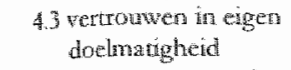 & & 4 \\
\hline 4. 4 eraren auto nomie & $\frac{\hbar}{t}$ & ţ่ \\
\hline \multicolumn{3}{|c|}{ 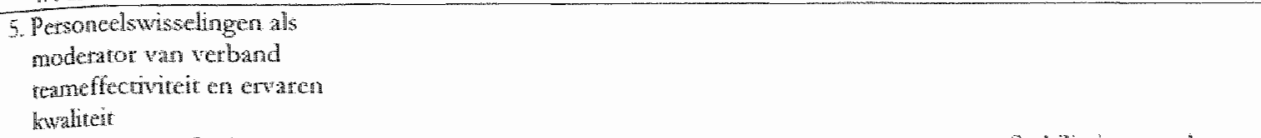 } \\
\hline 5.1 abedissatisfactie & & Sitabiliten = moderator \\
\hline 5.2 roldudelithelat & & Stabiliteir $=$ modetaros \\
\hline $\begin{array}{l}5.3 \text { vertrowwen in eigen } \\
\text { doelnatigherd }\end{array}$ & & \\
\hline 5.4 ervaren aubonomie & & \\
\hline
\end{tabular}

\section{Tabel 8.21c Samenvating resultaten onderzoekswatag 6}

6. Model van samenhang tussen woongwephenmetken personeelswisselingen er teanebectiviten als poorspellers wan erwaren kwalineit van begeleiding.

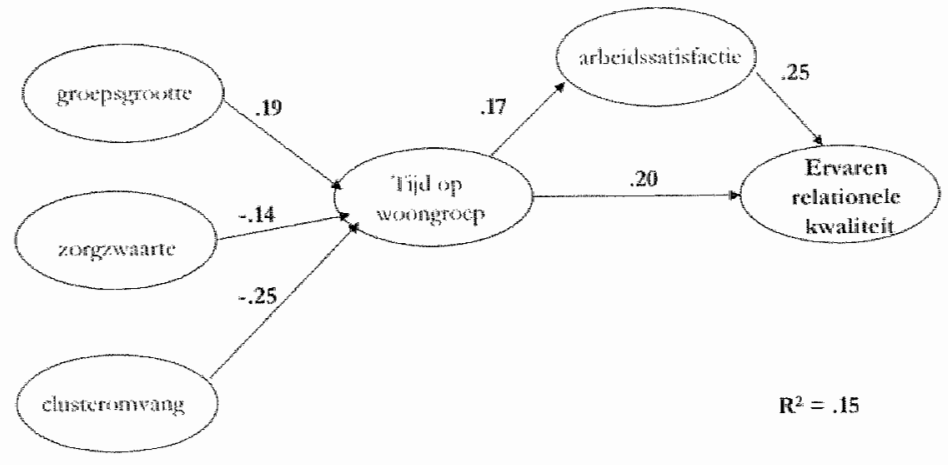

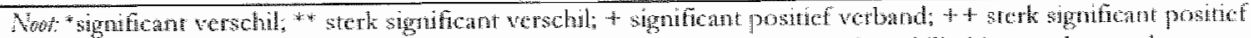

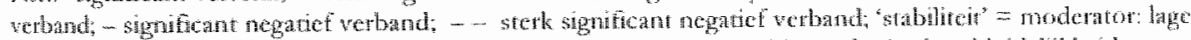

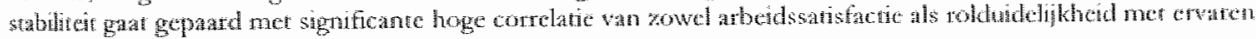
relationele kwalinet wan begeleiding.
} 



\section{Conclusie, discussie en aanbevelingen}





\subsection{Conclusies}

Deze studie werd ondemomen met het doel inzicht te verwerven in het verschijnsel personeelswisselingen in residentiele instellingen voor mensen met verstandelike beperkingen. Er werd gezocht naat de samenhang tussen personeelswisselingen (PW), organisatiekenmetken (A), teameffectiviteir (B) en door de familie van bewoners ervaren kwaliteit van begeleiding (C). Deze vomen de vier kernelementen van de probleemstelling (figuru 9.1).

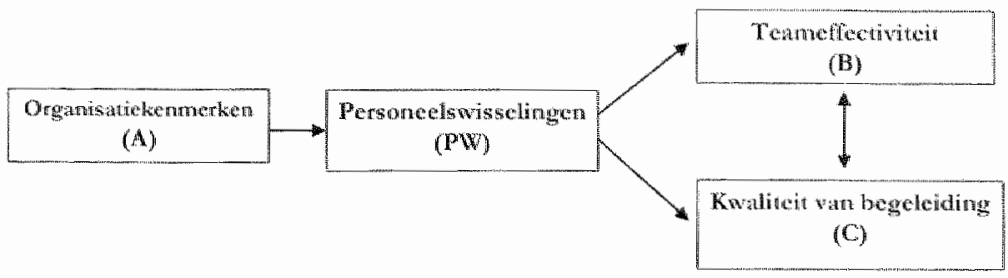

Figuur 9.1 Kernelementen van de probleemstelling

Met betrekking tor deze kernelementen vond een literatururverkenning plats (hoofdstukken 2, 3 en 4) die wetd afgesloten met een conclusie en de definitieve formulering van onderzoeksvragen (hoofdstuk 5). Daarna werd een enpirisch onderzoek opgezet en uitgevoerd (hoofdstukken 6,7 en 8). Op grond hiervan kunnen in dit hoofdstuk de volgende conciusies worden geformuleerd.

Historische bromnen tonen aan dat 'verloop' in professionele residentiële zorgorganisaties voor mensen met verstandelijke beperkingen van alle tijden is en samenhangt met economische en conjuncturele factoren (zoals bijvoorbeeld de arbeidsmarkt), culturele factoren (zoals bijwoorbeeld het stoppen met werken bij huwelijk of het werken van religieuzen in de zorg), en branchegebonden factoren (zoals het imago van het werk). Over de verhouding tussen "verloop" en interne "personeelswisselingen" in het verleden bestaan geen cijfers. Wel is annemelijk dat personeelswisselingen samenhangen met de sterke professionalisering en de bedrifsmatige opzet van residentiële zorg na invoering van de $A W B Z$. Daarnaast toont het historisch perspectief an dat ondanks verschuivingen in dominerende zorgrisies en organisatiestructuren, de structuur van de basiseenheid of operating core van residentiele instellingen en de groepsmatige werkprocessen van fromt-line medewerkers niet noodzakelijk mee veranderen. Woongroepen werden tijdens de laatste decennia wel kleiner en huisvesting verschuift vanaf het midden van de jaten negentig in snel tempo van het instellingsterrein naar 'buiten', maar koppeling van woongroep en woongroepteam, de functioncle opbouw van woongroepteams en een zekere standaardisering van teamstructuren onafhankelijk van doelgroepen, bleven in de praktijk bestaan. Steeds kleiner wordende (wat betreft FTE) en gdijktjdig meer versnipperd rakende woongroepteams (wat betreft antal medewerkers: 83 procent werkt deelujds) verhogen de gevoeligheid van residentiële begeleidingsteams woor personeelswisselingen. 
De vakliteratuur toont aan dat deze wisselingen bij familie van cliënten maar ook bij professionele begeleiders een continue bron van ergernis wormen. Het grootste deel van personedswisselingen hangt niet samen met verloop, maar wordt door de organisatie zelf geinduceerd; met name door de wijze waatop in vervanging van zieke of om andere redenen tijdelijk afwezige medewerkers wordt voorzien en door overplaatsingen van groepsleiders tussen woongroepen om andere redenen (bijvoorbeeld: aansluiting tussen competenties van groepsleiders en begeleidingseisen; jobrotation). Ruim eenderde van alle personeelswisselingen hangt samen met overplaatsingen van groepsleiders tussen woongroepteams.

Op grond van de wetenschappelijke literatuur is duidelitk dat frequente wisselingen wan begeleiders risicofactoren vormen voor de teameffectiviteit en voor de continuiteit en de kwaliteit van de begeleiding. Personeelswisselingen belemmeren zowel inhoudelijke aspecten van de begeleiding (wàt cliënten ontvangen) als relationele aspecten van de begeleiding (responsiviteit, communicatie en bejegening). Personeelswisselingen hebben een negatieve invloed op de sociaal emotionele aspecten wan begeleiding van de cliënten (responsiviteit en gehechtheid), beperken de continue beschikbaarheid van kennis (van individuele begeleidingsvragen en begeleidingsstrategieën) en belemmeren de implementatie van begeleidings-, informatieen kwaliteitssystemen.

Zowel cliënttevredenheid als werkreacties van teamleden in de front-office vormen in de context van kwaliteitszorg relevante indicatoren. In de wederkerige relaties tussen dienstverlenende organisaties en cliëntsystemen kunnen personeelswisselingen worden opgevat als verstoringen van de relationele continuiteit van de begeleiding. Continuiteit van begeleiding is voor het functioneren van mensen met verstandelijke beperkingen, en derhalve voor de kwaliteir van begeleiding een belangrijke factor.

Personeelswisselingen zijn vanuit het cliëntperspectief nauwelijks voorwerp van empirisch onderzoek geweest. Dat is wel het geval voor 'verloop' vanuit organisatieperspectief. Lit studies in residentiële instellingen met de omvang van het verloop als uitkomstvatiabele, blijken de volgende interne organisatiefactoten relevant: (soort) instelling, woongtoep op instellingsterrein of binnen de samenleving, grootte en zorgzwaarte van woongroepen. Verder blijken werkreacties van medewerkers (waaronder arbeidssatisfacte, participatie in besluitvorming, doelmatige onderlinge samenwerking en duidelijkheid over hun taken) samen te hangen met verloop.

De meest recente conceptualisering van 'verstandelijke beperkingen" erkent de belangrijke rol van de omgeving voor het functioneren van personen met functioneringsproblemen.

Social-ecologische modellen laten zien dat de primaire omgeving van de persoon (zoals gezin of woongroep) daarin een cruciale rol vervult. Binnen deze microomgeving vinden de interacties van de persoon met anderen plaats en worden 
invoeden van andere contexten (bijvoorbeeld: het woongroepcluster, de instellingsorganisatie, de regelgeving, de cultuur) doorgegeven. Bronfenbrenners sociaalecologische theorie laat zien dat relaties tussen (begeleidende) personen in twee verschillende primaire omgevingen van de cliënt (in ons geval: familie en groepsleiders in woongroepen) van belang zijn voor de interacties van begeleiders met cliënten binnen de woongroep. Zo beinwloedt het vertrouwwen tussen familie en woongroepteam (twee primaire microsystemen van de persoon met verstandelijke beperkingen) de effectiviteit van de begeleidingsrelaties van dit team met bewoners van de woongroep.

In de marketingtheorie van dienstenorganisaties blijken modellen te bestaan die geheel compatibel zijn met deze inhoudelijke implicaties van de sociaal-ecologische theorie. Met name het model van Hartline en Ferrell legt verbanden tussen de door cliënten ervaren kivaliteit van dienstiverlening en factoren als arbeidssatisfactie, rolduidelijkbeid, wertrouwen in eigen doelmatigheid en ervares autonomie van het dienstenteam. Deze laatste vormen, in de context van kwaliteit van dienstverlening, effectiviteitfactoren. Het ligt voor de hand om te veronderstellen dat personeelswisselingen een negatief effect hebben op deze effectiviteitsfactoren.

Aan de hand van de inhoudelijk gerichte sociaal-ecologische theorie en van de organisatiegerichte marketingtheorie werden richtinggevende stellingen geformuleerd. Op basis hiervan werd vervolgens een theoretische model uitgewerkt (figuur 9.2).

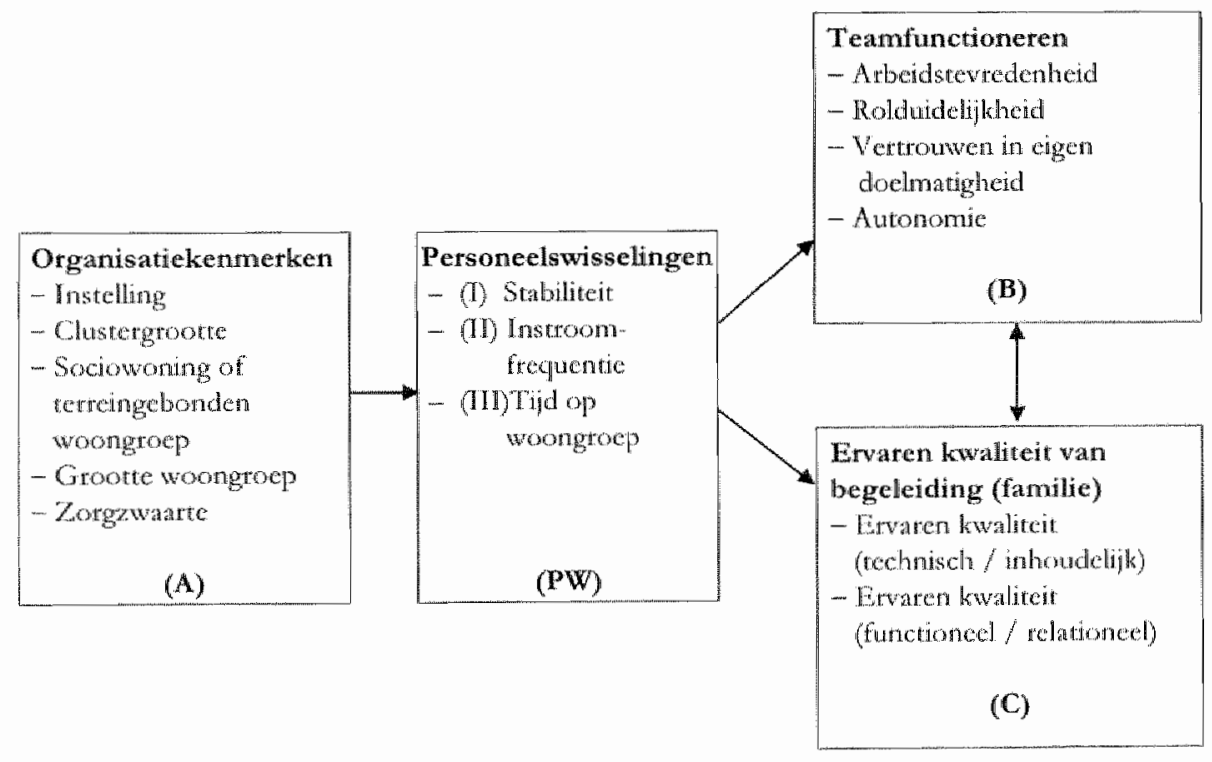

Figuur 9.2 Theotetisch model 
De problectristlling voor het onderzoek luidde: "Wat is de samenhang russen personeelswisselingen (PW), organisatekenmerken (A), effectiviteit van het teamfunc. toneren $(B)$, en de door het clientsysteem ervaten kwaliteit van begeleiding ( $C$ )?

Het theoretische model gaf ordening aan de variabelen die uit de literatuurstudie naar woren waren gekomen en liet toe de onderzoekswragen als volgt te formuleren: 1. lis er een verband tussen woongroepkenmerken en personeelswisselingen (APWT?

2. Is er cen verband tussen personeelswisselingen en teameffectiviteit (PW-B)?

3. Is er een verband tussen personeelswisselingen en door familie ervaren kwaliteit van begeleiding ( $\mathrm{PW}-\mathrm{C})$ ?

4. Is er een verband tussen de teameffectiviteit en de door familie ervaten kwaliteit van begeleiding (B-C)?

5. Welke rol spelen personeelswisselingen bij het eventuele verband tussen de teameffectiviteit en de door het cliëntsysteem ervaren kwaliteit van begeleiding (PW-B/C)?

6. Kan een model worden opgesteld van de samenhang tussen (1) woongroepkenmerken, (2) personeelswisselingen en (3) kenmertken van teamfunctioneren als voorspellers van de door familie ervaren kwaliteit wan begeleiding $(\mathrm{A}-\mathrm{PW}-\mathrm{B}-\mathrm{C})$ ?

De beantwoording van deze vragen leidt tot de volgende conclusies.

1.1 De gemiddeld aangetroffen teaxstabiliteit is 66 procent: na éen jaar is gemiddeld tweederde van de vaste teambezetting nog aanwezig. Instellingen verschillen onderling niet significant wat betreft de gemiddelde stabiliteit van de woongtoepteams. Er werd wel een grote variatie aangetroffen: van teams met een stabiliteit van nul $(n=2)$ tot 100 procent $(n=18)$. Stabiliteit lijkt op instellingsniveau vooral samen te hangen met de factor 'verloop'.

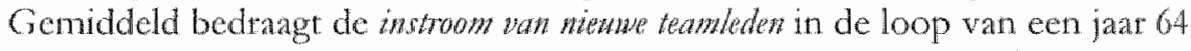
procent. Ook hier zijn er grote variaties: in vijf teams betrof de instroom méér dan 200 procent; in twee teams was er geen instroom van nieuwe tcamleden. De verschillen tussen de instellingen zijn voor deze maat wel significant. De instroomfrequentie is meer functic van het vervangingsbeleid van de instelling.

De gemiddelde diensitid van groepsleiders binnen het team (tuid op woongroep) bedroeg in de onderzochte woongroepen drieènveertig maanden. Ook hier bestaat een grote variatie: in 25 procent van de gevallen bedroeg deze minder dan tweeëntwintig maanden; in 25 procent bedroeg de gemiddelde dienstujjd méér dan tweeënzestig maanden. Instellingen verschillen significant op deze maat.

1.2 De stabilitati van teams is hoger naarmate woongroepen deel uitmaken van grotere clusters. Ook in sociowoningen is de stabiliteit hoger. De instroomfrequmite van nieuwe groepsleiders is gunstiger (lager) in teams die 
deel uitmaken van grotere clusters en eveneens iets gunstiger in woongroepen met grotere zorgzwaarte. In grotere woongroepen maken groepsleiders langer deel uit van het team. Kleine teams en klcine clusters van teams vormen ongunstige factoren voor de onvang wan personeelswrisselingen.

2.1 Er is een positief verband tussen de shabihtit van het woongroepteam en door groepsleiders ervaten vertrouwen in doelmatigheid van hun team en de door hen ervaren autonomie. Er is ook een positief verband tussen de wroblyfsdum van grocpsleiders in hun team en de gemiddelde arbeidssatisfactie, rolduidelijkheid, vertrouwen in doelmatigheid en autonomie van teamleden.

2.2 Grotere stabiliteit van het woongroepteam gaat gepaard met groter vertrouwen in eigen doelmatigheid en met een grotere ervaren autonomie van het team. Een langere gemiddelde verblijfsduur in het team gaat gepaard met gunstiger uitkomsten voor alle aspecten van teameffectiviteit: arbeidssatisfactie, rolduidelijkheid, vertrouwen in eigen doelmatigheid en ervaren autonomie.

3.1 Waar groepsleiders langer deel uitmaken van hun woongroepteam, blijkt gemiddeld een hogere tevredenheid van de familie met de relationele aspecten van de kwaliteit van begeleiding te bestaan. Bij stabielere teams is de familie daarenboven meer tevreden over de inhoudelijke kwaliteit van de begeleiding.

3.2 Er is een duiclelijk positief verband tussen door familie ervaren kwaliteit van begeleiding en (minder) personeelswisselingen.

4. In woongroepen waar groepsleidets meer arbeidssatisfactie ervaren blijkt de familic een hogere kwaliteit van begeleiding te ervaren. Dit verband bestaat ook met door groepsleiders ervaren rolduidelijkheid en autonomic. Er is sprake van een spiegeleffect waarbij de causaliteit van het effect voorzichtig benaderd moet worden; uit de literatuur blijkt een wederkerig effect te bestaan tussen effectiviteitaspecten en cliënttevtedenheid. De gevonden cotrelaties van het spiegeleffect zijn klein en de gemeenschappelijkc variantic is nergens groter dan 7 procent. Van de zeven facetten van arbeidssatisfaclie van de MAS-GZ, blijken de facetten tevredenheid met "leidinggevende", 'mogelijkheden tot realiseren van eigen competenties' en 'duidelijkheid' het sterkste verband met cliënttevredenheid te hebben.

5. Er is een wisselwerking tussen de stabiliteit van het team en het verband tussen respectievelijk arbeidssatisfactic en rolduidelijkheid, en de door familie ervaren kwaliteit van begeleiding. Lagere stabiliteit van het woon- 
groepteam bljkt eon groter effect te hebber op het spiegeleffect tussen arbeidssatisfactie of rolduidelikheid en door familie ervaren kwalteit van begeleiding. Lagere stabiliteit lijkt het spiegeleffect te sensibiliseren: in dat geval is lage arbeidssatisfactie stetker verbonden met lagere tevredenheid van familie, maar omgekeerd is een hogere arbeidssatisfactie in dat geval verbonden met een hogere tevredenheid van familie met de begeleiding.

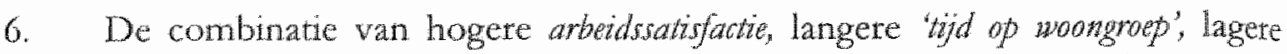
zorgzwaarte, grotere woungropgrootie draagt het meest bij tot de verklaring van de tevtedenheid van de familie met de relatonth kwaliteit van begeleiding, Daarbij lijkt een grotere clusteromvang eveneens een positieve rol te spelen. In totaal kan 15 procent van de variantie in tevredenheid met deze factoten worden verklaard.

\subsection{Discussie}

\subsubsection{Methodologische beschouwingen}

Voor de interpretatie van de uitkomsten van ons onderzoek zijn de wolgende methodologische kanttekeningen wan belang.

Ten eerste is de keuze voor de instelingen uit dit onderzoek niet aselect tot stand gekomen. Weliswar betreft het instellingen waarvan de populatie cliènten representaticf is voor de totale populatie van Nederlandse instellingen, maat dat geldt niet noodzakelijk voor de regionale arbeidsmatkten waarbinnen de instellingen functioneren. Verschillen in deze arbeidsmatktsituatics kunnen van invloed zijn op verloop en daamee ook op een deel wan de geconstateerde personeelswisselingen. Voonal de stabiliteitsmaat kan daarvoor gevoelig zijn. Generalisatie van de uitkomsten naar 'alle' Nederlandse residentielle instellingen is daarom niet zonder meer mogelijk.

In de wwede plasts gat het om een cross-sectioneel onderzoek. Ook al werden de gegevens ovet personeelswisselingen over de periode van een vol jaat verzameld, toch werden de werkreacties van groepsleiders en de tevedenheid van familic slechts op én moment gemeten. Het is niet mogelijk om aan de hand van dit soort cross-sectioned onderzock causale verbanden wast te stellen. Alle in dit onderzoek gerapporteerde verbanden moeten darom als cotrelationele verbanden wotden gezien. Ook de complexere verbanden zoals die bij de onderzoksvagen wijf en zes werden onderzocht, leiden niet tot uitsptaken over causaliteit van de onderzachte samenhang. Dit belet niet dar kennis van deze verbanden relevante wetenschappelijke en praktische inzichten kan opleveren.

Ten derde theeft ons onderzoek betrekking op het woongroepniveau. De reden hiervoor is dat personeelswisselingen zich op dat niveau voordoen en hiet dan ook een hoppeling nussen personeelswisselingen en de factoren wan teamfunctioneren en van kwaliteitservaringen van de familie kan worden gemakt. Voordeel is dat deze uiteenlopende factoren gelijktijdig, binnen éen analyse kunnen worclen onder- 
zocht. Nadeel is dat de informatie van het individuele niveau (van medewerkers en familie) ongebruikt blijft. Omdat het aantal instellingen beperkt is en dit onderzoek niet gericht was op factoren op individueel niveau, werd geen multilevel analyse toegepast. Een dergelijke analyse zou op dezelfde data in principe wel mogelijk zijn, zij het dat in dat geval zou gaan om twee afzonderlijke analyses (én voor de werkreacties van medewerkers, en één voor de door familie ervaren kwaliteit van begeleiding). Personeeiswisselingen zouden dan als woongroeplenmerk kumnen worden beschouwd. Nadeel is dat in het geval van analyse van de werkreacties, de door familie ervaren kwaliteit van begeleiding niet kan worden betrokken. In het geval van analyse van door familie etvaren kwaliteit, geldt mutatis mutandis herzelfde voor de werkteacties. Dit belet niet dat het zinvol is deze afzonderlijke analyses in de toekomst uit te voeren.

Ten vierde werd in onze analyses impliciet uitgegaan van lineaire verbanden tussen de variabelen. Het theoretische model geeft geen aanleiding on andere verbanden te veronderstellen en inspectie van scatterplots van de onderzochte verbanden leverde geen overtuggende afwijkingen van lineariteit op. Tabel B8.9 laat een onverwacht verloop zien van de correlaties tussen arbeidssatisfactie (MAS) en door familie ervaren kwaliteit van begeleiding (CPSQ) in de vier bereiken van de instroomfrequentie (INFR), maat dit geeft onvoldoende aanleiding on de veronderstelling van linearteit te verwerpen. Voorts werden significante correlaties gevonden tussen de responspercentages en zowel de mate van arbeidssatisfactie als de 'tijd op woongroep' (paragraaf 8.1.3). Dit kan motivatiefactoren weerspiegelen: langer verblijf binnen het zelfde team (waarbij ook een gemiddeld hogere arbeidssatisfactic wordt aangetroffen: tabel $\left.8.16 ; \mathrm{r}=.18^{*}\right)$ kan gepaard zijn gegaan met grotere participatiegeneigdheid met het onderzoek. Hiermee is in de analyses geen rekening gehouden.

Ten wijfde werd in dit onderzoek geen rekening gehouden met het 'wie' aspect van de kwaliteit van dienstrerlening; het type dienstverlener (functie) kan van invloed 7.jin op de individuele ervaring van de ontvangen clienst (De Vries, Van Helsdingen \& Kasper, 2001) en op effectiviteitaspecten (Zijlstra, 2003). Ons onderzoek betreft de cliëntervatingen met betrekking tot teamprestaties als geheel.

\subsubsection{Inhoudelijke beschouwingen}

\section{Teamstabiliteit}

Stabiliteit van de woongroepteams blijkt een sensibiliserende factor voor het werband tussen teamfunctioneren en door familie ervaren kwaliteit van begeleiding. Dat betekent dat de organisatie bijzonder bedacht moet zijn op situaties waarin de stabiliteit van het team onder druk staat. In dergelijke gevallen dient aandacht te worden besteed aan de arbeidssatisfactie van teamleden en aan de duidelijkheid van hun tol in het begeleidingsproces van de cliënten (Hatton et al., 1999). Gelijktijdig dient extra aandacht te worden besteed aan de relatie tussen her team en de contacten met het sociale netwerk van de bewoners. Wanneer relatief veel leden 
van her waste team bimen een jar vertrekken, kan het vertrouwen in het team worden behouden of beworderd doot "derden", die zowel het vertrouwen van de grocpsteiders als de familie genieten, en brugfunctie te laten vervullen (zie paragtaf 4.2 .2 ). In de meeste (traditionele) residentiele instellingsorganisaties is dit cen functie van maatschappelik werkenden. Ook een leidinggevende (buiten het woongroepteam), persoonlifk begeleider of andere medewerkers die een langere relatie hebben met de bewonet en de familie (bij voorkeur buiten het woongroepteam), kunnen deze brugfunctie vervullen. Her voomien in een dergelijke brugfunctie vormt een andachtspunt in kleinere cn zelfstandig werkende teams.

\section{Instroom van nieuwe grocpsleiders}

Voor het beperken van door de organisatie zelf geinduceerde personeelswisselingen dienen residentiele instellingen hun vervangingsbeleid kritisch te bekjken. VerWanging van (lijdelijk) afwezige groepsleiders dient zo dicht mogelijk bij de woongroep te worden georganiseerd mer medewerkers die bekend zijn met de overige reamleden, met de bewoners en met de technologie (werkwizen, procedures, attitudes, systemen). Dit aspect verdient vooral aandacht in woongroepen net grotere zorgzwaarte omdat hier soms een hogere instroomfrequentie wordt geconstateet. Het grote andeel van niet-uitstelbare, dagelijks terugkerende en fysieke begeleidingactiviteiten makt dat vervanging dringender gewenst is dan in woongroepen warvan de bewoners zelfstandiger zijn en begeleidingsactiviteiten gemakkeljkker uitstelbaar zijn.

Grotere woongroepen en grotere verbanden van woongroepen bliken gunstige factoren te zijn, mits vervanging binnen dit verband kan worden geregeld In het belang van de effectiviteit wan het teamfunctioneten en de door het clientsysteem. crvaten kwaliteit van begeleiding dient andacht te worden besteed aan de omvang. en de samenstelling van het begeleidend team.

\section{Gemiddelde dienstijd binnen het woongroepteam}

Daatnaast moet de gemiddelde totale dienstajd wan een team kritisch gevolgd worden. Wanneer ingtipende veranderingen in de teamsamenstelling onvermidelijk of juist wenselijk zipn, zouden zoweel als mogelijk die maatregelen genomen moeten worden die de gemiddlelde 'rijd op woongroep' het minst negatief beinvoeden. Men moet dus vermijden dat meerdere groepsleiders met lange dienstijd binnen in het team gelijktijdig of binnen een kort tijdbestek het team verlaten. Op die manier blijft kennis over de begeleiding van de bewoners behouden en makt overdracht van deze kennis nati nieuwe teamleden meer kans. Vanwege de impact van personedswisselingen op her teamfunctioneren en op de kwaliteitservaring van her clientsysteem moeten deze worden beschouwd als kwaliteitsindicatoren. 


\subsubsection{Wetenschappelijke beschouwingen}

\section{Wisselingen versus verloop}

Door het management van organisaties wordt werloop algemeen gezien als cen indicator voor effectiviteit en kwaliteit. Als zodanig behoott deze factor ook tot de benchmarking in het kader van kwaliteit en performance van gehandicaptenorganisaties (Vereniging Gehandicaptenzorg Nederland, 2002c). Waar het gat om de kwaliteit van het primaire proces of de 'service enconnter' zelf waar de interactie tussen dienstverleners en cliënten plaatswindt, is 'verloop' geen gocde indicator ondat daamee een grove onderschatting wordt gemaakt van de discontinuiteit die de cliënten in werkelijkheid ondervinden. In onderzoek naar kwaliteit of performance van vraaggetichte begeleidingsprocessen dient dan ook de voorkeur te worden gegeven aan personeelswisseling-maten boven verloopmaten. In dit onderzoek werden drie verschillende maten geconstrueerd voor het meten van verschillende modaliteiten van personeelswisselingen: stabiliteit van het team, instroomfrequentie van nieuwe medewerkers, en de (gemiddelde) dur van het teamlidmatschap. De stelling van Artow en McGrath dat continuitteit en verandering in teamsamenstelling verschillende fenomenen zijn en tot verschillende effecten leiden (paragraat 3.2.1), wordt door ons onderzoek bevestigd.

\section{Teameffectiviteit en kwaliteit van dienstverlening}

De in ons onderzoek gevonden verbanden zijn in overeenstemming met de door Hartline \& Fetrell (1996) gevonden relaties tussen effectiviteitaspecten van dienstenteams en de door cliënten waargenomen kwaliteit van dienstverlening. Binnen dit model kunnen op grond van ons onderzoek, personeelswisselingen worden opgevat als belemmerende factoren voor de teameffectiviteit in dienstverlening met een langdurige karakter en met name daardoor als belemmerende factoren voor de door cliènten ervaren kwaliteit van de dienstverlening. De factor 'personeclswisselingen binnen een dienstenteam' dient daarom in marketing- of kwaliteitsstudies nar clienttevredenheid als een relevante belemmerende of bevorclerende factor te worden beschouwd. Het doot ons geformuleetde theorctische kader is cen bruikbaar model voor de studie van deze factoren.

\section{Marketingtheorie en sociaal-ecologische theorie}

Onze studie laat zien dat organisatie- en inhoudelijke benaderingen van zorg en ondersteuning geen conflicterende benaderingen zijn. Fr bestaat congruentie tussen de inhoudelijke social-ecologische benadering van professionele begeleiding van mensen met verstandelijke beperkingen en de organisatietheoretische benadering, in het bijzonder de benadering vanuit de marketingdiscipline. Deze congruentie is verankerd in de interactics tussen directe dienstverleners (front-fine medewerkers) en 
clienten. Deze vinden plaats binnen dyades die daarmee als het werkzame aspect van de dienstentelatie kunnen worden opgevat. Voor de studie van deze serwicedyades vormt zowel de social-ecologische theorie als de marketingtheorie een relevant kader. De uitkomsten van empirisch onderzoek vanuit beide theorieen vormen relevante kennisbronnen voor de evidence-based organisatie van primaire dienstenteams en voor de opleiding van front-line medewerkers. Gezien de omvang van het huidige body of know/dge van de marketingdiscipline ligt hierin een vruchtbare voedingsbodem voor opleiding, organisatieontwikkeling en kwaliteitszorg in de professioncle ondersteuning wan mensen met verstandelijke beperkingen.

\subsection{Aanbevelingen}

\subsubsection{Aanbevelingen in het kader van kwaliteitsbeleid}

\section{Continürteit in de begeleiding}

Personeelswisselingen dienen in het kader van vraaggerichte en klantgerichte zorg als kavaliteitsindicatoren te worden aangemerkt: er is een duidelijk verband tussen personeelswisselingen en zowel de effectiviteit van het begeleidend team als de door cliënten ervaren kwaliteit van de dienstverlening. Om die reden verdient het aanbeveling om personeelswisselingen op het niveau van de primaire dienstenteams te monitoren.

Monitoning dient plaats te vinden op drie modaliteiten van personeelswisselingen:

De stabiliteit van het team (antal medewerkers dat het afgelopen jaar constant deel uitmaakte van het vaste team in relatie tot de omvang van het team).

De instroomfrequentie van nieuwe medewerkers (aantal voor het eerst instromende medewerkers, ongeachte de duur van hun teamlidmaatschap, in relatie tot de omvang van het team).

De gemiddelde tijd dat alle huidige medewerkers deel uitmaken van het betreffende team.

Deze modaliteiten dienen als afronderlijke indicatoren te worden aangemerkt.

Op grond van dit onderzoek is het niet mogelijk om exacte drempelwaarden van deze indicatoren op te stellen. Het onderzoek geeft wel aanleiding om voor te stellen een stabiliteitswaarde van 50 procent of lager als indicatie van problematische stabiliteit te hanteren (paragtaaf 8.7). Dat betekent dat wanneer in de loop van cen jaat 50 procent van de vaste teamleden uit de begeleiding van de cliënten verdwijnt het risico op een sterk verband tussen lage arbeidssatistactie, verminderde rolduidelijkheid en lage tevredenheid van de familie met de kwaliteit van de begeleiding sterk toeneemt. In dat geval moeten arbeidssatisfactie en tolduidelijkheid van teamleden andacht krijgen.

Wanneer veel tijdelijke vervanging van medewerkers in (woongroep)teams plaatsvindt - gemeten over de laatste twaalf maanden (hoge instroomfrequentie) - 
moeten gelijkrijdige neerwaartse verschuivingen in stabiliteit (vertrek van vaste teamleden) en in de gemiddelde diensttijd van de teamleden worden vermeden. Een indicatiewaarde van een problematische instroomfrequente van vervangers kan bij 100 procent worden geplaatst (evenveel verschillende tijdelijke vervangers als er vaste teamleden zijn stromen binnen twaalf maanden in - paragraaf 8.7). Dit kan door tijdelijke vervanging zoveel als mogelijk te tealiseren met medewerkers die bekend zijn bij de cliënten èn de andere teamleden en door definitieve vervangingen te spreiden. Dit is gemakkelijker wanneer onderlinge vervanging plaatsvindt binnen hetzelfide team of vanuit een pool vervangers zo dicht mogelijk bij het team. Het oogmerk moet zijn vervanging te tealiseren met medewerkers die zoveel als mogelijk vertrouwd zijn met de cliënten, hun begeleidingsvragen, de toegepaste begeleidingstrategieën en met teamgebonden technologicën (zoals informatiseringsysteem en kwaliteitssysteem). Hier ligt een relatie met de grootte van teams en dusters. Op dit aspect wordt in paragraaf 9.3.2 nader ingegaan.

Vooral in teams met een lage gemiddelde diensttijd van medewerkers dient extra andacht te worden besteed aan hun arbeidssatisfactie. In dit soort 'jonge' teams is er een duidelijker verband tussen arbeidssatisfactie en de door familie ervaren kwaliteit. Op gtond van dit onderzoek is het niet mogelijk om exacte drempelwaten voor deze indicator op te stellen. Indicatief kan op grond van de resultaten van dit onderzoek (tabel B8.10) worden aangenomen dat een gemiddelde dienstijd van twaalf maanden en minder (van teamleden binnen hetzelfde team) met zekerheid gepaard gaat met een verhoogd spiegeleffect tussen arbeidssatisfactie van mede-werkers en door familie ervaren kwaliteit. Bij 'jonge' teams moet bijzonder aandacht worden gegeven aan het bevorderen van arbeidssatisfactie.

\section{Critical incident beleid}

Wanneer personeelswisselingen binnen een team niet vermijdbaar blijken - zoals bij een hoog verloop, reorganisatie of veranderende taken - kunnen op grond van de resultaten van dit onderzoek en van de sociaal-ecologische theorie aanbevelingen worden gedaan om de risico's op effectiviteits- en kwaliteitsverlies te beperken. Bij nieuwe woongroepteams en wanneer een groot aantal reeds langet in het team werkende groepsleiders binnen een korte periode (korter dan een jaar) her team werlaten (lage stabiliteit), dient men extra aandacht te geven aan:

De arbeidssatisfactie van de groepsleiders en in het bijzonder hun tevredenheid met de leidinggevende en de manier waarop zij hun eigen competenties kunnen realiseren binnen dit team.

De duidelijkheid over taken en rollen van groepsleiders in dit specifieke team en de verwachtingen van bewoners en familie.

De ervaringen van de familie met betrekking tot de geboden begeleiding en de communicatie met het team.

In individuele contacten of (informele) bijeenkomsten van teamleden en belangrijke leden van het sociale netwerk van cliënten, kan wederzijds kennis over de bewoners 
en over verwachtingen en ervaringen met betrekding tot de begeleiding worden uitgewisscld. Communicatie over deze onderwerpen kan het tisico verminderen op achteruitgang van cliënttevredenheid naar aanleiding van de vele personeelswisselingen. In die omstandigheden kan het nuttig zijn derden (van buiten het woongroepteam) in te schakelen die zowel het vertrouwen genieten van groepsleiders als familie (zie de besproken brugfunctie in paragtaaf 9.2.2).

Nicuwe en sterk "verjongde" teams (met lage gemiddelde diensttijd van de teamleden) dienen gedurende een periode van twaalf maanden bijzonder aandacht van leidinggevenden en / of coaches te krijgen. Deze teams zijn bijzonder kwetsbaat bij het (opnieuw) opbouwen van een interne structuur en wisselingen kunnen hun adaptief vermogen daarbij overvragen (Arrow, 2000). Vooral hun arbeidssatisfactie (relatie tot leidinggevende, duidelijkheid en het realiseren van eigen competenties) dient daarbij aandacht te krijgen. Hun relatie met het sociale netwerk van de bewoners bijikt hier namelijk gevoelig voor. Bij nieuwe teams is het tiskant al te sterk te vertrouwen op het 'zelfsturend vermogen' van de teamleden en verdient her aanbeveling te voorzien in extra coaching. In deze coaching dienen de inhoudelijke aspecten van het werk en de relarie met cliënten en hun sociale netwerk centraal te staan; zij dient dus niet alleen te gaan over werkomstandigheden.

\subsubsection{Aanbevelingen voor strategisch management}

\section{Naar een open systeem van ondersteuning}

In paragraaf 4.1 .4 (figuur 4.1) werd de samenhang tussen marketing, kwaliteit en strategisch management besproken. Bij marketing is kennis van de behoeften en vtagen van cliënten uitgangspunt voor het vormgeven van klantgerichte begeleiding. Effectieve beantwoording van de begeleidingsvragen is de kem van dienstverlening; de mate waatin dit tot tevredenheid van het cliëntsysteem plaatsvindt, bepaalt de kwaliteit van de dienst vanuit cliëntenperspectief. Omdat personeelswisselingen zowel met de effectiviteit van het teamfunctioneren als met de tevtedenheid van cliëntsystcem samenhangen, vormen zij voor het sttategische beleid van residentiele instellingen cen relevante factor.

Instellingen hebben in toenemende mate te maken met emancipatie van cliënten en de verwachting dat de geboden begeleiding inspeelt op hun individuele vragen en omstandigheden. Dit gat gepaard met meer individuele begeleidingsarrangementen en kleiner wordende begeleidingssetrings. Deze bevinden zich steeds minder geconcentreetd op een instellingstertein, en steeds meer verspreid in gewone huisvesting binnen de samenleving. Zoals in hoofdstuk 2 werd toegelicht, worden ook steeds meer professionele diensten ingeroepen door familie van cliënten die zelf huisvesting hebben geregeld. Verdet leidt het 'ondersteuningsparadigma' ertoe dat niet de indivicuele client het voonwerp van professionele begeleiding vormt, maar de relatie van de cliënt met zijn sociale netwerk en met algemene diensten waarvan hij gebruik maakt. Tot deze laatste behoren generieke publieke en private diensten zoals bijwoorbeeld angepaste voorzieningen (gemeente), huisvesting (woning- 
corporaties), gezondheidszorg (huisartsen), thuiszorgorganisaties, vervoersdiensten, maaltijdverstrekking en alarmering. Voor de residentiële instelling betekent dit een drastische verschuiving in de aard van de te leveren diensten. Residentiele zorg verschuift nadrukkelijk van een gesloten systeem waarover de organisatie nagenoeg de volledige regie had over alle door de cliënt gevraagde functies, naar een open systeem waarin professionele ondersteuning in samenhang en samenwerking met anderen gebeurt. Dit leidt tot consequenties voor de inrichting en het functioneren van begeleidingsteans.

\section{Naat netwerkorganisaties en ondersteuningsteams}

Binnen het traditionele organisatieconcept worden begeleidingsteams tot nu toe nog overwegend gekoppeld aan woongroepen: een groepsmatig en gesloten organisatieconcept. Klantgerichte en vraaggerichte ondersteuning vereist meer individuele, kleinschalige en flexibele ondersteuning. Woongroepen worden daarom steeds kleiner (en in een gekoppeld systeem van woongroepen en woongroepteams dus ook de teams) terwijl de complexiteit van levering van functies toeneemt. Begeleiding wordt naast persoonlijke fysieke en sociale assistentie, steeds meer informatie- en relatiemanagement met daarin veel communicatie over individuele cliëntwensen, over professionele mogelijkheden, over uitkomsten van ondersteuning, over ervaren kwaliteit (tevredenheid) en met overleg met uiteenlopende partijen. Binnen een klein team kunnen de noodzakelijke competenties en coördinatiemogelijkheden niet meer worden geboden en daarenboven blijken deze teams een groter risico op discontinuiteit op te leveren. Hiermee ontstaat een paradox: vraaggerichte ondersteuning vraagt om kleinere verbanden maar kleinere teams vormen een kwalliteitsrisico.

Het ligt voor de hand te concluderen dat de levenscyclus van de traditionele residentiële zorgorganisatie ten einde loopt. Omgevingsveranderingen zoals de toenemende emancipatie van mensen met functioneringsproblemen, zorgzwaartefinanciering en persoonsgebonden budget, regelgeving (modernisering van de AWBZ), deconcentratie, individualisering, vraggerichtheid en vermatschappelipking van de ondersteuning dwingen tot aanpassing van de organisatie. Deze aanpassing kan niet meer gebeuren door kwantitatieve verschuivingen in bestaande structuren maar vereist een herontwerp van de organisatie, in het bijzondler van de operating core of interface tussen organisatie en cliëntsysteem (Abraham, L. 1994; Galbraith, J.R., 2002; Hammer \& Champy, 2001; The Commitree on the Quality of Health Care in America, 2001). Deze interface is de plats waar de diensten concreet tot stand komen; de hoeksteen van de langdurige relatievorming tussen cliënt en begeleider (Van Wijk \& Van Dijk, 2003). In deze veranderende ongeving vereisen behoud en verbetering van effectiviteit en kwaliteit van de begeleiding grotere teamverbanden.

Het ontwerpen van nieuwe ondersteuningsteams voor (tesidentiële) begeleiding vormt een interessante opgave. Omdat functies zoals bijvoorbeeld huisvesting. onderhoud, werving en selectie, arbeidsomstandigheden en behandeling steeds 
waker worden wibesteed en mer meer betp wordt gedaan op algemeen maatschappelijke hulpbronnen (bijvoorbeeld: huisartsen), zullen netwerkorganisaties meer in beeld komen. Deze uiteenlopende hulpbronnen en competenties moeten cchter dicht bij het cliêtutsystem geintegreerd worden binnen een continu beschikbare begeleiding, zonier kunnen teams in toenemende mate met diversiteit, versnippering en coördinatieproblemen worden geconfronteerd.

Integratie van competenties en coördinatie kunnen plaatswinden in cen 'ondersteuningsteam" dat zo zelfstandig mogelijk in stat is een clièntengroep, ongeach hun woonsituatie, te begeleiden. De clienten van eenzelfde ondersteuningsteam kunnem individueel, in sleine groepjes, in het gezin of in een grotere woonvom wonen. Een cliëntengroep kan gebaseetd zijn op geografie (wijk, gemeente, of ook eventued op een apart terrein), en/of op vraagstellingstype (Kok, 1991). Een ragstellingstype mag niet worden verward met een 'diagnosecategorie' en het gaat dus ook niet om zogenaamde 'diagnose-behandel combinaties' (DBC) die thans in het kader van beheersbarheid in de curatieve zorg worden ontwikeld (Ministerie wan Volksgezondheid, Welzijn en Sport, 2003). Het gaat om vergelijkbare of werengbare ondersteuningsbehoeften. In termen van organisatie gaat het om teams die worden gevormd op grond van ondersteuningsprofielen van cliënten en de daarbij horende competenties. Ondersteuningsproficlen hebben betrekking op de aard en de intensiteit van nauw omschreven ondersteuningsbehoeften (luckasson at al, 2002; Thompson, Hughes, Schalock, Silverman, Tassé, Bryant, Craig, \& Campbel, 2002; "Thompson, Bryant, Campbell, Craig, Hughes, Rotholz, Schalock, Silverman, Tassé \& Wehmeyer, 2004). Omdat ondersteuningsteams op basis van ondersteuningsbehoeften van cliënten en van ondersteuningscompetenties van medewerkers worden samengesteld kunnen mensen met vergelijkbare ondersteuningsbehoeften maar met uiteenlopende 'aandoeningen' door eenzelfde team worden ondersteund. Een logische consequentie is dat de dienst-markt combinaties van traditionele begeleidingsorganisaties grondig kunnen veranderen (Alkemade, Janssen \& Meijer, 1995; Dirks, Van Duren, Blom \& Thoolen, 2001).

Structuur: en samenstelling van ondersteuningsteams moet in overeenstemming wotden gebracht met ondersteuningsprofielen van cliënten. Dergelijke ondersteuningsteams dienen kennis op essentiele begeleidingsterteinen (medisch, psychologisch en pedagogisch en kennis owet de sociaal-maatschappelijke omgeving) samen net competenties op het terrein van financied beheer, human resource management en facilitaire dienstvetlening in zich te verenigen. Een ondersteuningsteam kan in structurele zin worden opgevat als een semi-autonome eenheid of 'strategic service unit' (SSU).

Figuur 9.3 toont een hypothetisch model van een dergelijke organisatie met integraal samengestelde ondersteuningsteams - dat wil zeggen, met ondersteunings medewerkers en de relevante disciplines om zelfstandig de noodzakelijke ondetsteuning an een groep clienten te kunnen leveren. 


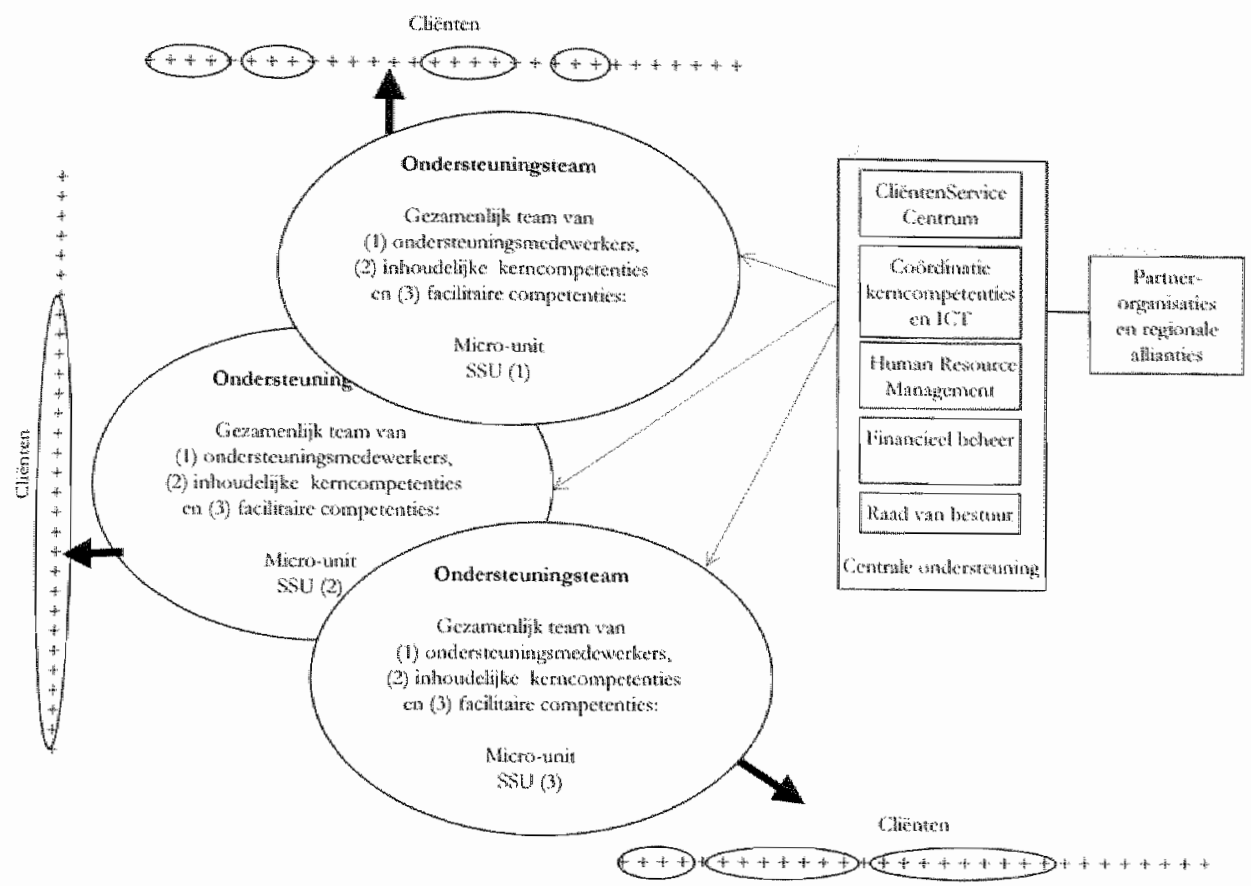

Figuur 9,3. Hypothetisch 'ondersteuningsteam-model' gebaseetd op micro-units

Cliënten wonen niet noodzakelijk samen op één locatie, maar kunnen verspreid in de regio wonen: individueel, in kleine groepjes (kleine cirkels), of thuis bij hun ouders.

Voor de inhoudelijke organisatie van het 'ondersteuningsteam' kan het micro-tunit concept model staan (Donaldson \& Mohr, 2000; Nelson, Batalden, Huber, Mohr, Godfrey, Headrick, \& Wasson, 2002). Voor de organisatiestructurele component kan de SSU model staan (Ginter, Swayne \& Duncan, 1998). SSU's hebben een hoge mate van zelfstandigheid in hun werkgebied (bijvoorbeeld binnen een geografisch gebied en een bepaald clientenprofiel naar ondersteuningsbehoeften).

Aanpassing aan de nieuwe omgeving (van verwachtingen van de cliëntsystemen, van regelgeving, van concurrentie) vereist verandering van de residentiële organisatie. Dit proces neemt veel tijd in beslag omdat de omgevingsfactoren slechts langzaam wijzigen, omdat er sprake is van een quasi-markt waarin de vrijheid van opereren en organiseren van zorgaanbieders beperkt is, en omdat er sprake is van inertie van de organisatie (die tegenover medewerkers, cliënten en alliantiepartners gebonden is door afspraken en aangegane verplichtingen). Om deze reden vinden snelle aanpassingen, zeker in grote organisaties, niet plaats (Miller \& Mintzberg. 1984). 
Deze omstandigheden maken echter dat et tijd is om alternatieve organisatievormen - bijvoorbeeld gebaseerd op micro-systemen en kleine regionale service units te ontwerpen en op hun merites te onderzoeken. Het creëren en wetenschappelijk evalueren van experimentele ondersteuningssystemen is voor de ontwikkeling van effectieve en efficiënte ondersteuningsorganisaties een vetantwoorde investering en een interessante uitdaging. 


\section{Literatuur}



Abraham, L. (1994). Beyond continuity and towards thidity of care. Rethinking long-tern care for an aging society. Ala Hogtizaka, 1993/94, 71-75.

Albecht, G.L. \&. Wheger, P.J. de (1999). The Disability Paradox: high quality of life againgt all odds. Social Snene of Medicine, 48,977-988.

A.kemade, N.O.E. Janssen, R.T.J.M. \& Meijer, A.W.M. (1995). Het marktconcept als hulpmiddel bij strategische beleidsworming: casus social-medische advisering. GGD mewns, $(5), 27-31$.

Aper, $S$. (1998). Tnterdependence and Controversy in Group Decision Making: Antecedents to

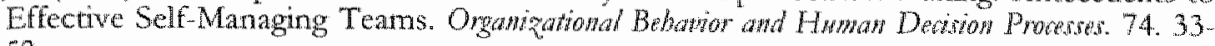
52.

Arrow, H. \& McGrath, JE. (1995). Membership Dynamics in Groups at Work: a Theoretical

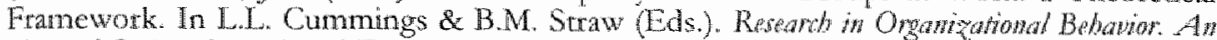

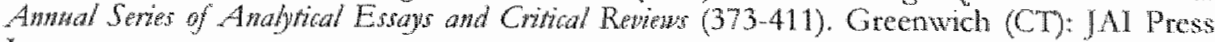
Inc.

Atrow, H. (1997). Stability, Bistability, and Instability in Small Group Influence Patterns Joutwil of Persowality and Social Pychology, $72(1), 75-85$.

Arow, H., McGrath, J.E. \& Berdhal, J.L. (2000). Small groups as complex syrems: Formoston, coordination, development, and adaptation. London: Sage Publications.

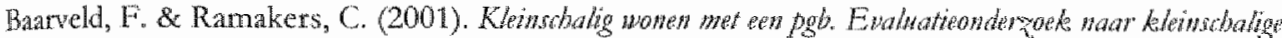

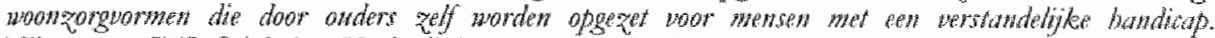
Nijmegen: TTS; Stiching Katholieke Universiteit Nijmegen.

Baher, B.L. \& Blacher, J. (2002). For Better or Worse? Impact of Residential Placement on Famillies. Mental Retardation, 40 (1), 1-13.

Barker, R.G. (1965). Explotations in Ecological Psychology. Amerion Psyologist, 20, 1-14.

Batnlard, M.C. \& Meerveld, J.H.C.M. (1992). Handhiding Zorghowen. Utrecht: Nationaal Zickenhuisinstitunt.

Baron, R.M \& Kenny, D.A. (1986). The Modetator-Mediator Vatiable Distinction in Social Psychological Research: Conceptual, Strategic, and Statistical Considerations. Jouthat of Personality and Sicial Psycbology, 51 (6), 1173-1182.

Baron-Epel, O., Dushenat, M. \& Friedman, N. (2001). Evaluation of the consumer model: relationship between patients' expectations, perceptions and satisfaction with care. Intomational Journal for Quatity in Health Care, 13 (4), 317-323.

Bartels, I.P. (2001). Instellingen wan intramumale gezondheidszorg. Basiggegenens per 1-1-2001. Unecht: Prismant.

Baumeister, A.A., \& Zaharia, ES. (1987). Withdrawal and Commiunent of Basic-Cate Saff in

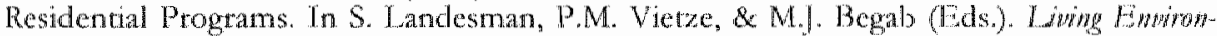
ments and Mentad Rehardation. (229-267). Washington, American Association on Mental Reardation.

Bebko, C. (2000). Service intangibility and its impact on consumer expectations of service quality. Jotmal of Senvices Martering, 14 (1), 2-26.

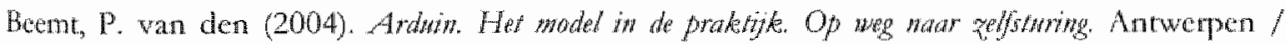
Apeldoorn: Garant.

Beijer, W. (2000) Her persoonsvolgend budget: een katalysator voor verschuiving van macht. In G.H.MM. ten Horn, W.H.E. Buntinx, JA.J. Coolen, E.Th. Klapwij, W.A.L. van Leeuwen, B. wan Zijderveld (Red.). Handboek Mogelijtebedes. Vraaggerichte zorg wor mensen met een werrandelipe Mandicap (VI.1.3-1,-21). Maarssen: Elscvier.

Beradsgroep Community Care (1998). Leven in de locale samenlening. Adwes aver Community Care mar

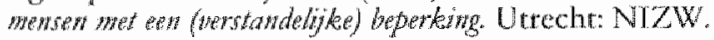

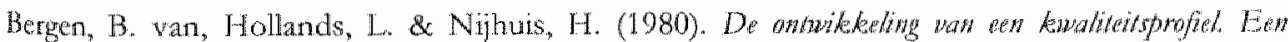
methode wor het beoordeles van terpleeglesudig bandelen. Lochem: De Tijdstroom.

Bergers, G. (2000). Integratic gehandicapten. Ades Magazine, 4, 35 37. 
Berg-Willemscn, A. Brams, J., Peketharing H\& Wymenga, S. (2001). Kijk naar wat we zegen. Zongvaagverduideliking bij mensen met cen ernstige verstandelije handicap. In G.H.M.M. ren, W.H.E. Buntinx, J.A.J. Coolen, E.Th. Klapwik, W.A. van Leewwen, B.

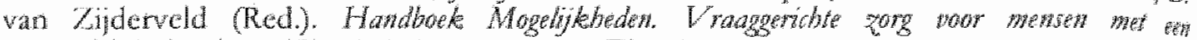

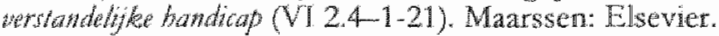

Bering, R. \& Nabitz, U (2000). Verniewwingen in MK \& EFQM-model. Betehenis roox

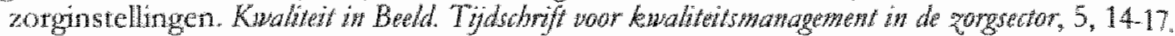

Berkson, G. (1978). Social Ecology and Ethology of Mental Retardation. In G.P. Sacketr (Ed). Obreving Behawor. Volome I: Theory and Apphations an Mental Retardation. Baltimore: Universin Park Press, 403-409.

Bernard, S., Buntinx, W. \& Huyer Abu-Saad, H. (1998). Zorgintensiteir als basis yoon personeelsverdeling: werslag wan een ontwikkelings- en valideringsstudie. Nederiowds Tijdsdbrift poor de Zorg and werstandelije gehanditapten. (24) 3, 127-141.

Bernat, S, Maskant, M.A., Gevers, J.P.M. \& Wierda, H. (2001). Voorspellingen ten aanzien van het aantal oudere mensen met een verstandelijke handicap in algemene woonvoorzieningen 1996-2001. Nederlands Tifdschift woor de Zorg aan werstandedjk gehandicatoten. (27) 3,166-177.

Betry, J.O. (1995). Families and Deinstitutionalization: An Application of Bronfenbrenners Social Focology Model. Jounnal of Connseling and Development, 73, 379-383.

Berwick, D. (1989). Continuous improvement as an ideal in health care. The Now England Journat of Mediane, $320,53-56$

Besamusca Janssen, M.(1997). Kantgeribt managewent in mon profionganiraties. Baam: Nelissen.

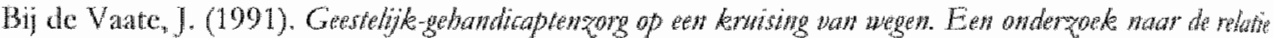

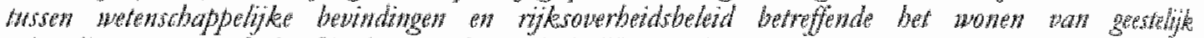
gehandicapten (proefschrift). Amsterdam: Vrije Universiteit.

Bijlsma, J. (2003). De zorgzame professional. Tijdschrift woor Soctos Pedagogische Hutpoerlening, 53, 4 7.

Bitner, M.J. (1995). Building Service Relationships: It's All About Promises. Jownal of the Academy of Markering Sriene, 23 (4), 246-251.

Blaker, B.L. \& Blacher, J. (2002). For Better or Worse? Impact of Residential Placement on Families. Mental Retardation, 40(1), 1-13.

Bleekrode, R, Beckers, A. \& Sturm, R. (1974). Verslaggeving en evaluatic van ecin

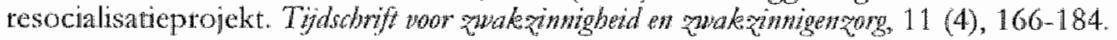

Bltmenthal, S., Lavender, T. Hewson, S. (1998). Role clarity, perception of the organization and burnout amongst support workers in residential homes for people with intellectual disability: a comparison between a National Health Serwice trust and a charitable company.

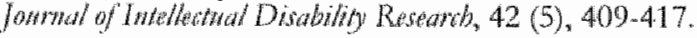

Bontridder-Michiels, M. de (1987). Omgevingskenmerken en zorgkwaliteit. Een onderzock rond de verhuizing van 750 geestelijk gehandicapten binnen de Stichting Sint Anna. RUT, 51, 3 . 14.

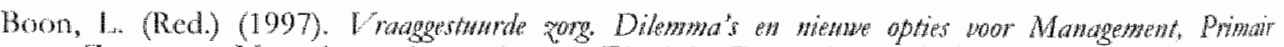

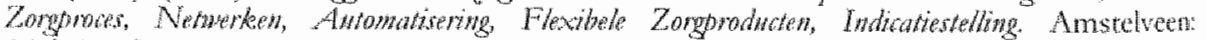
Stichting Sympoz.

Borst- Filers, E. (2000). Atteptan Zong Verwederd Geradpleegd 28.02.2004, op hep://www.nietafwachten.nl/documenten/mi061100.pdf en htop//wwwggzbeleid.nl/pdfwacht/actieplan_zotg_verzekerd pdf .

Bouwmans, C.A.M., Ineveld, B.M. van, Custers, T., Bandel, A.P., Sol, J.C.A., Wagner, C.,

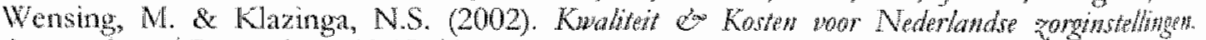
Amsterdam / Rotterdam: AMC / Institute for Medical Technology Assessment.

Bowlby, J. (1988). A Seatre Base Clinical applications of attachnem theory. London: Routledge. 


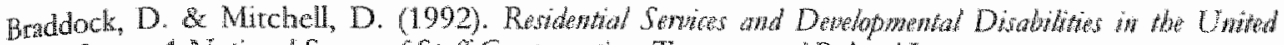

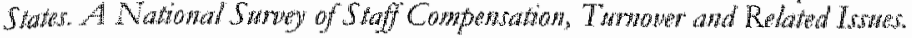

Baddock, D. \& Parish, S. (2002). An Instinutional History of Disabilicy. In D. Braddock (ed), Disablity at the Dawn of the 21 ir Cewats (1-61). Washington: Anerican Association on Mental Retardation.

Braddock, D. (Ed.) (2002). Disability at the Dawn of the 2/st Cenowy. Washington: American Association on Mental Recardarion.

Brink, C. var den (1979). De inrithring is zo gek nog niet vook zwakzinnige mensen. Tijdidwit wor pistrowatoriche thexpie, $8(2), 38-55$.

Brockhoven, T. van (1999). De zorgconsulent: adviseur, pleitbezorger en belangenbehattiger. In G.H.M.M. ten Horn, W.H.E. Buntinx, J.A.J. Cookn, E.Th. Klapwik, W.A.L wan

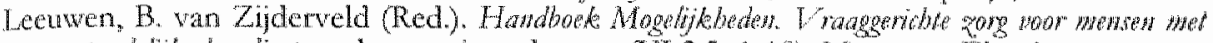

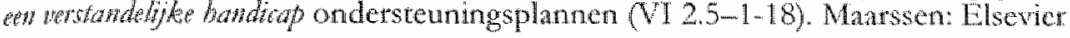

Bronfenbrenner, U. \& Ceci, S.J. (1994). Nature - Nurture Reconcepoualizacion in Dexelopmental Perspecrive: A Bioecological Model. Pyothological Reprow, 101, 568-585.

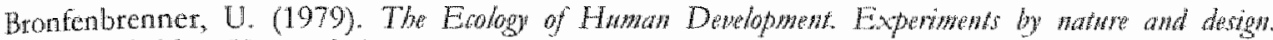
Cambridge: Haward University Press.

Bronfenbrenner, U. (1986), Ecology of the Family as a Context for Human Development: Research Perspectives Developmental Psyctology, 22, 723-742.

Bronfenbenner, U. (1999). Environments in Developmental Perspective: Theoretical and

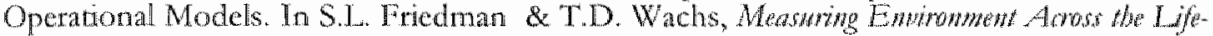
Sipan (3-28). Washington: American Psychological Association.

Brothwick-Duffy, S.A. (1990). Quality of life of persons with severe or profound mental retardation. In R.L.Schalock \& M.]. Begab (Eds.). Quality of life. Perspetive and Issues. Washington: American Association on Mental Retardation.

Browwer, JJ. (1992). Samenwerken of concurteren (I). Levenscyclus diensten dwingt verzorgingstehuizen naar nieuwe wegen te zoeken. De lsstehling, $17(10), 49-51$.

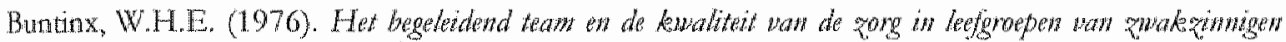
(Anna-calhier). Heel Stichting Sint Annal.

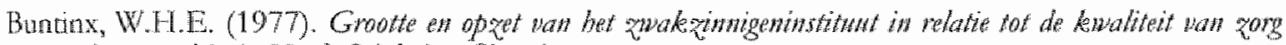
(Ama-cahter). Heel; Stichting Sint Anna.

Buntinx, W.H.E. (1979). Enige aspekten van kwaliteitsbewaking in de zwakzinnigenzorg. RUMT, december $1979,5-11$.

Buntinx, W.HE. (1994). Continuiteit in residentiele zorg voor monsen met een verstandelijkc handicap. In C.J.M. Jindner-Middendorp, L.P.T. Raijmakets, D.A. Fikwecrt, R.F. B. Geus

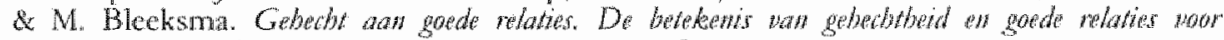
wertandelijk gehandiapte menen $(62-73)$. Assen: Van Gorcum.

Buntinx, W.H.E. (1997a). Zorgontwikkelingen in Scandinavie, Groot Britannea en de Verenigde Staten. In G.H.M.M. ten Horn, W.H.I. Buntinx, J.A.J. Coolen, E.Th. Klapwijk, W. A.L.

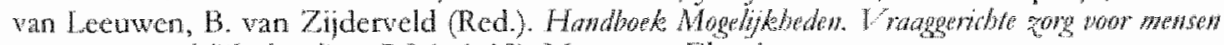

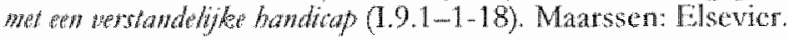

Buntinx, W.H.E. (1997b). In de spiegel van Heksinki. De remmende voorsprong nader bekeken.

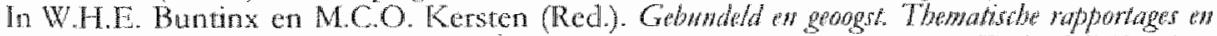

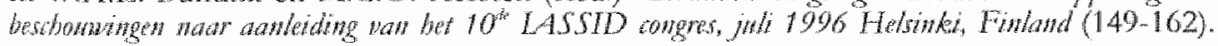
Utreche $N G B Z$ en BBI.

Buntinx, W.H.E (1998), Vraggerichte zorg. Een managementmodel. In G.H.M.M. ten Horn, W.H.E. Buntinx, R. Habekothe, E.Th. Klapwigk, W.A.L van Leewwen \& B. wan Zijderveld

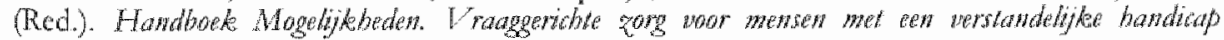
(V.22-1-29). Maarsen: Eilsevier. 
Bunein, W.H. $\mathrm{E}$. 2000). Zorg in Lijn. Over samenhang en effectiviteit in de zorg aan mensen met een verstandelije handicap. In W.H.E. Buntinx \&. H.M. wan Tol (Red.), Zorg in Ijy.

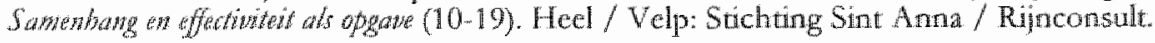

Buntinx, W.H. (2001). Personeelswisselingen en organisatiekenmerken in woongroepen wan

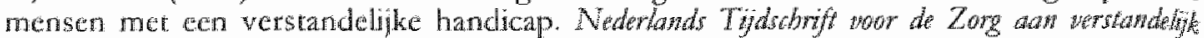
gehowdisatysen, $27(2) 86-104$

Buntinx, W.H.F. (2002a). De Intertational Classification of Functioning, Disability and Healh' (ICF) en de nieuwe definitie van verstandelike handicap van de American Association on Mental Retardation. In G.H.M.M. ten Horn, W.H.E. Buntinx, R. Habekothe, E.Th. Klapwik. W.A.L. van Leeuwen \& B. van Zijderveld (Red.). Hawdboek Mogelgkbedow.

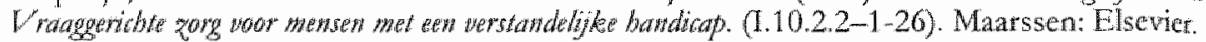

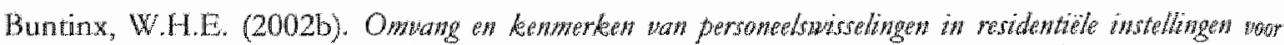

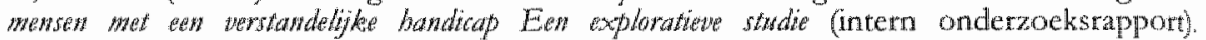
Maastricht: Universiteit Maastricht (BEOZ).

Buntinx, W.H.E. (2003a). Wat is cen verstandelijke handicap? Definitie, assessment en ondersteuning volgens het AAMR-model. Nederlands Tifdstbrift woor de Zorg atan verstamdelisk gebatidiablen. 29 (1), 4-24.

Buntinx, W.H.E. (2003b). Tevredenheid over ondersteuning. Ondersteuning met tevredenheid. In P. van den Beemt (Red.). Ardizw. De meg kaor Indisie (173-199). Antwerpen / Apeldoon: Garant.

Burlingham, D. \& Freud, A. (1943). Young Children in Warkime A Year's Work in a Rasidenial War Nirsegy. London: George Ailen \& Unwin Lid.

Burlingham, D. \& Ineud, A. (1947). Introduction of the Mother-Relationship into Nursery-Life.

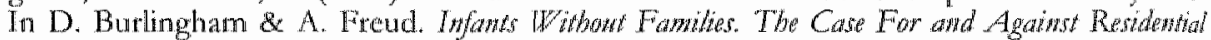
Nurseries (43-52). London: George Allen \& Unwin Itd.

Casparie, A.F. (1998). Sturen op kwaliteit: via de professionall of op het systeem? Kwaliteit zorg. 4,151154

Casparie, A.F, Foets, M., Raaijmakers, M.F, Bakker, D.H. de, Schneider, M.J., Sterkenburg, P.S, Janssen, C.G.C., Biyman-Schulte, A.M., Bakker, R.H., Moorer, P., Dassen, Th.W.N \&

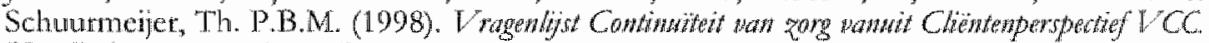
Handliding en magnlijsten. Den Haag: NWO onderzoekprogramma Kwaliteit var Zorg.

Caton, D.J, Grossnickle, W.F., Cope, J.G., Long, T.E. \& Mitchell, C.C. (1988). Burnout and Stress Among Employees at a State Institution for Mentally Retarded Persons. Amercots Jontwat on Mental Retardation, 93-3, 300-304.

CBS (Centraal Bureau voor de Statistiek) (2004). Bewotking, totad en in instituties Geradplecgd 26.02.2004, op htp://www.cbs.n//nl/cjfers/statlinc/index htm

Chronisch zicken en Gehandicapten Raad Nederland, 2001. Kmolfwnten de kinderen/jongerem met wh

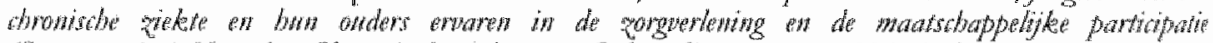
(Samenwatring). Utrecht: Chronisch zieken en Gehandicapten Raad Nederland.

Cichert, D. \& Cohen, D.J. (Eds.) (1995). Dewelopmental Psphopatbology. New York: Wriley \& Sons.

Climens, A. (2003). The Otganization of Difference: People With Intellectual Disabilities and the Social Model of Disabilicy. Mentat Retarkation, 41 (1), 35-46.

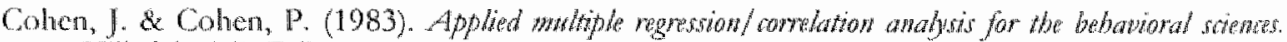
Hillsdale, NJ: Eribaum.

Cohon, S. \& Wills, T.A. (1985). Stress, Social Support, and the Buffering Hypothesis. Psydologiat Bulletin, $98,310-357$.

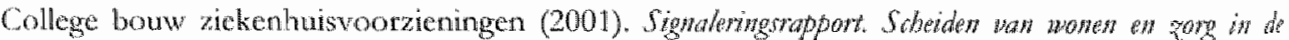

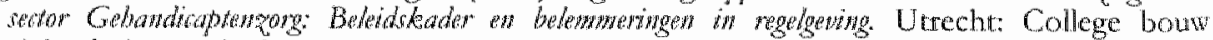
rickenhuswootzieningen.

College Taticven Gezondheidszong - CTG (2002). Jaawerilag 2002. Utrecht: CTG. 


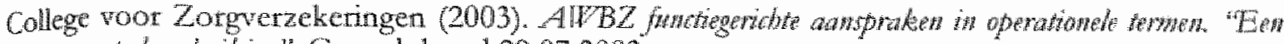
werste baydretking". Geraadpleegd 29.07.2003, op

http:/ www.opkopzorg,nl/material/handreikingCVZversie1.0.doc.

Coolen, ]. (2003). Aarbod van gehandicaptenzorg. In G.HM.M. ten Horm, W.H.E. Buntinx, H.T. Habekothé, E.Th. Klapwijk, W.A.L wan Leeuwen \& B. wan Zijderveld (Red.).

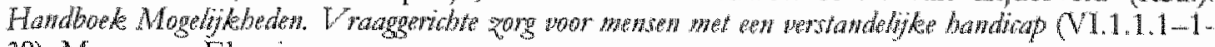
39), Marssen: Elsevier.

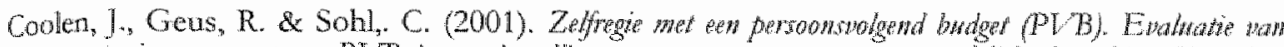

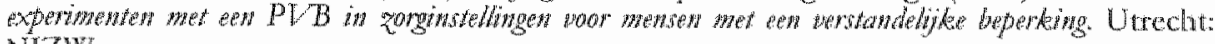
NIZW.

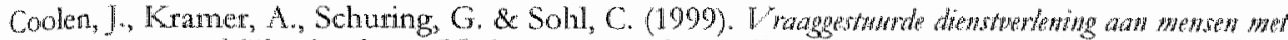

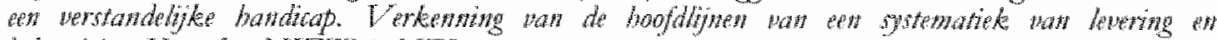
bekstiging Utrecht: NIZW \& NZI.

Cope, J.G. Grossnickle, W.F., Cowington, K.B., Durham, Th,W, \& Zahara, E.S. (1987), Saff Turnover as a Function of Performance in a Public Residential Facility. Amerion Jomwat of Mestal Deffiency, 92-2, 151-154.

Cox, K., Peeters-Niemantsverdriet, S., Philipsen, H., Neumann, M., Campen, C. van \& Huyer-

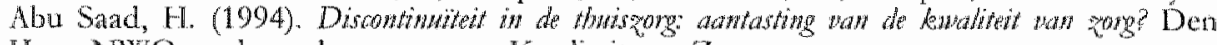
Haag: NWO, onderzoeksprogramma Kwaliteit van Zorg.

Cremers, P. (1998). Persoonsgebonden bekostiging en verstandelijke handicap. In G.H.M.M. ten Hom, W.H.E. Buntinx, J.A.J. Coolen, E.Th. Klapwijk, W.A.L. wan Leewwen, B. van

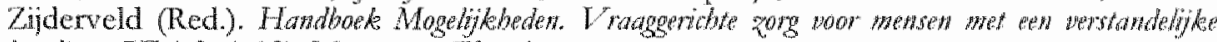
Bavdrat (V.1.3-1-13). Maarssen: Elsevier.

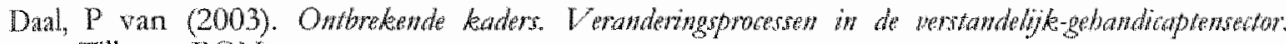
Tilburg: PON.

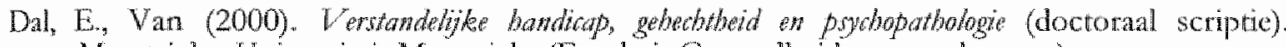
Masstricht: Univetsiteit Maastricht (Faculteit Gezondheidswetenschappen).

Damen, P.C. (1972). Organisatie on tednologie. Lochem: De Tujdstroom.

Delnoij, D.M.J., Asbrock, A.H.A. ten, Custers, T. \& Klazinga, N.S. (2002), Bakens zetten. Naarem

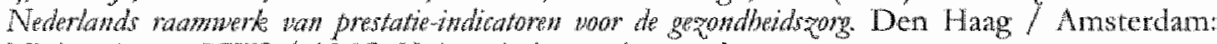
Ministerie van VWS / AMC, Universiteit van Amsterdam.

Derckx, M. Kloek, M. (2003). Thuiszorg als bedtiffstak in beweging. Concurrentic dwingt tot positionering. $Z M, 12,27-31$.

Derks, W. Vergrijzing en regionale markten. (2004a). Econominds Statishinbe Beriobun (LBS), 89 $(4425), 65-66$.

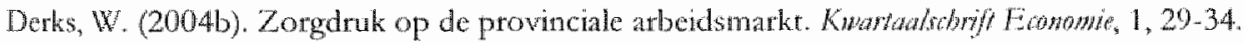

Diemel, C.G.M. (1993). De professionele bureaucratie: cen gepasseerd station. Het Zekerahois, 12, $572-574$.

Dirks, M., Duren, G. van, Blom, A. \& Thoolen, J. (2001). Smottghenowing in be MKB. Delf: TNO. STB \& Syntens.

Donabedian, A. (1980). Explonations in Qmalig Assessment and Monitoning (Folume I) The defintion of Qwally and approabes bo its assessyext. Ann Arbor: Health Administration Press.

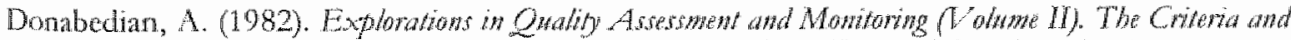
Standards of Qmality Arsessment ond Moritaring. Ann Arbor: Health Administration Press.

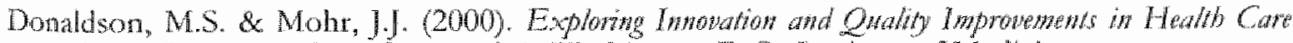
Whow System. A CrostCare Anahsis. Washington D.C. Institute of Medicine.

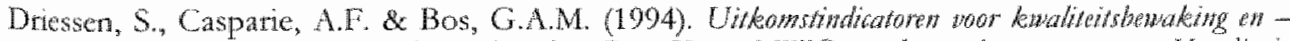

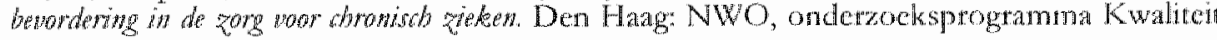
van Zorg:

Drucker, P.F. (1983). The Conept of the Corporatios. New York: New American Library. 
Dunn, W, Brown, C. \& McGuigan, A. (1994). The Ecology of Human Perfomance A Fismemork for Considering the Effect of Context. The Amonican Jowmal of Ocompational Thratapy, 29, $595-607$.

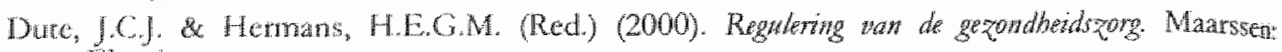
Hisevicer.

Dykens, E.M., Hodapp, R.M. de Finucane, B.M. (2000). Genetios and Mental Retardation Sywhowe. A New took at Bebanor and Interwentions. Baltimore: Paul Brookes.

Ebcnstein, W. (1996). Organizational change and the emerging parnership between ditwo support workers and people with disabilities. In T. Jaskulski \& W. Ebenstein (Eds.) Opportwitites for Excellente: Sxipponting the Fronthne Workfore (100-119) Washington DC. President's Committec on Mental Retardation (U.S. Deparment of Health and Human. Serwices).

Edwatds, P. \& Mitrenberg, R. (1991). Burnout Among Staff members ar Community Residential Facilities for Persons With Mental Retardation. Mental Rehardatian, 29-3, 125-128

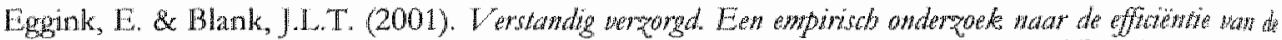

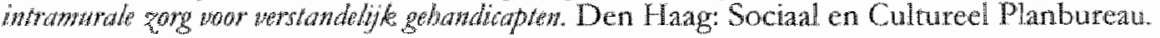

Ellemers, J.E, (2000). Sociale werschillen en verscheidenheid in Nederland: ontwikkelingen sinds de Tweede Wereldoonlog. In G.H.M.M. ten Horn, W. H.E. Buntinx, J.A.J. Coolen, E.Th. Kalapwijk, W.A.L. van Leewwen, B. van Zijderveld (Red.). Howdboek Mogelifheden.

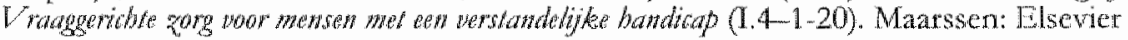

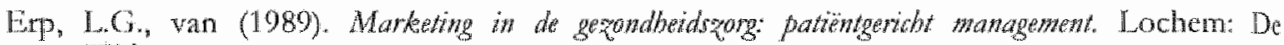
Tijdstroom.

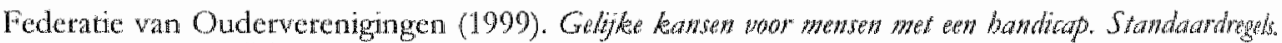
Regels wan de Ferwigde Naties. Utrecht: Federatic van Ouderyerenigingen.

Felce, D., Lowe, K. \& Beswick, J. (1993). Staff tumower in ondinary housing services for people with severe or profound mental handicaps. Journal of Intellectudi Disability Researdh, 37 (2), 143-152.

Felce, D. (1987). The Planning and Evaluation of Community-Based Residences for Individuals with Severe and Profound Mental Retardation. In S. Landesman, P.M. Vietze, \& M. Begals (Teds.). Liming Enwraments awd Mendal Retadation (127-149). Washington, American Association on Mental Retardation.

Felce, D. (1997). Defining and applying the concept of quality of life. Joumal of Intellerinal Diswbility Restant. 14 (2), 126-135.

liertl, O.C., Hartine, M.D. \& Lewas, G.H. (2002). Marteting Strategy. Mason (Ohio): South Westem / Thomson Learning.

lougeyrollas, 13. (Ld.) (1998). ICIDH and environmental factors [Special Issuel. Infemotional Neruork, 9.

feund, U.H. (2001). Immer dieser Wechsel beim Heimpersonal.. Relativiering cines Problems aus historischet sicht. $17 \mathrm{~N}, 70(1), 39-51$.

Fricanan, S.L. \& Amadoo, J.A. (1999). The Child Cate Environment: Conceptualizations,

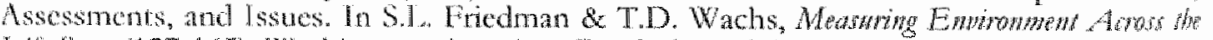
Life-Spat (127-165). Washington: American Psychological Association.

1.uhner, U. (1900). Bridging the Ecological-Psychological Gap. Behavior Setrings as Interfaces.

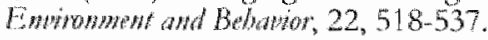

Gabraith, J.R. (2002). Deagning Onganizations. San Francisco: John Wiley \& Sons.

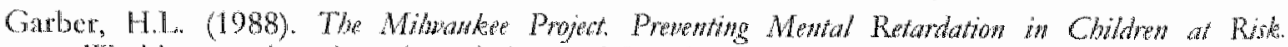
Washington: American Association on Mental Retardation.

Gavin, D.A. (1984). What Does 'Product Quality' Really Mean' Shom Mamagement Remen, 26, 2543. 
Gastel, W. Wark, Vermeer, A. \& Rispens, J. (2001). De constructic wat thet Kompas. Een richtiin voor de kwaliteitsevaluatie van de zorgstructum in orthopedagogische intermaten woot

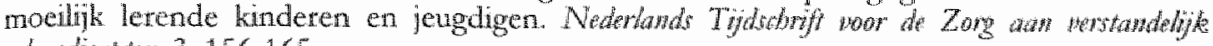
gethondicaptens, 3, 156-1.65.

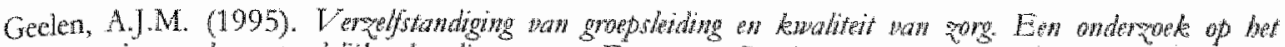

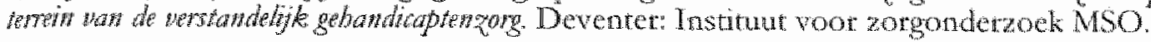

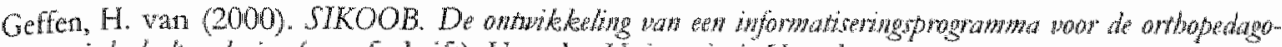
gishe butpwerlening (proefschnft). Utrecht: Universitei Utrecht

Gemet, G.H., Vvan (1994). Inleiding: gehechtheid en telatie als kernbegrippen in de zorg voor verstandelijk gehandicapten. In Lindner-Middendorp C.M.M., Rainmakers L.P.T., Fikweert

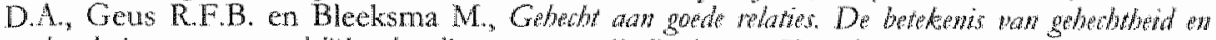

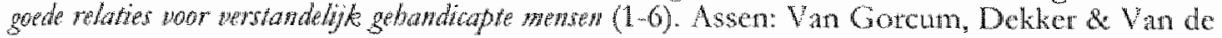
Vegt,

Gemert, G.H. van \& Peelen, A. (2001). Consultatie: samenwerken ara cen nieuw perspectiet. In G.H.M.M. ten Hom, W.H.E. Buntinx, J.A.J. Coolen, E.Th. Klapwij, W.A.L. van

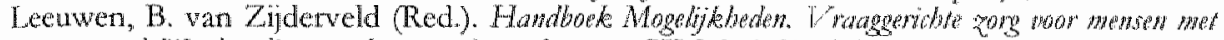
an persiavdelfike handiap ondersteuningsplannen (III.3.3-1-23). Maarssen: Blsevicr

Gement, G.H. van \& Vlaskamp, C. (1997). Individuele planning wan zorg. In G.H. van Gemert \& R.B. Minderaa. Zorg woor mensen met een wertandeligke Bandicap (33 43). Assen: Van Gotcum.

Gemert, G.H. van (2002). Het opstellen van persoonlijke ondersteuningsplannen. In G.H.M.M. ten Horn, W.F.E. Buntinx, J.A.J. Coolen, E.Th. Klapwijk, W.A.I. van Leeuwen, B. van

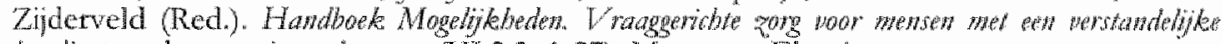
bandiop ondersteuningsplannen (VI.2.3-1-27). Maarsen: Elsevier

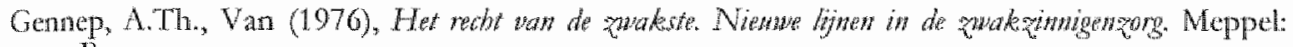
Boom.

Gennep, A. Th.G. van (1989a). Quality of care in Dutch residential facilities. The Britsh formal of Mental Submornatity, $35(68), 58-62$.

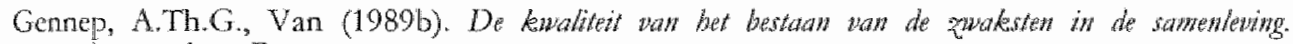
Amsterdam: Boom.

Gennep, A. van (1995a). Gedragsproblemen en de fysicke omgeving: ecologische aspecten. In

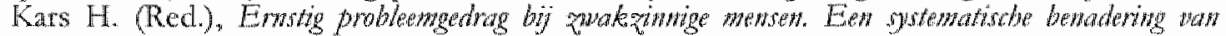
emstig probleengedrag in de zuakezinngenzom (htst. 7). Houten: Bohn Stafleu Van Loghum.

Gennep, A. van (1995b). Gedragsproblemen on de sociale omgeving ecologische aspecten. In

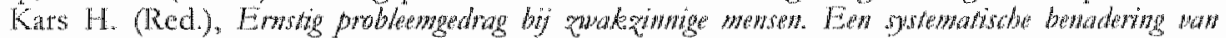

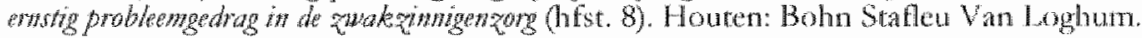

Gemep, A. Th. G. van (1997a). Quality of community living in the Netherlands. The Britso Journat of Denelopmental Disabilites, $43(84), 1-14$.

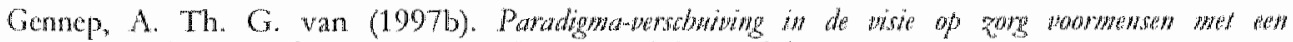
mersandelifke bowdiap. Masastricht: Universiceit Mastricht.

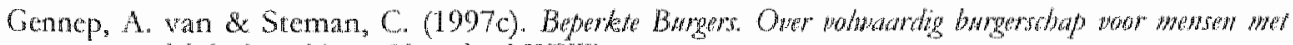
werstandelike beperkingen. Uttecht: N1ZW.

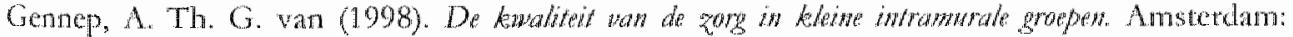
SCO-Kohnstamm Instituut.

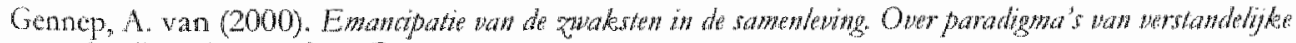
tandiap. Amsterdam: Boom.

Gemep, A. Th. G. wan (2002a). Leven in de samenlewing: van vtces natar hoop. NGBZ Newusbrief, aptil, $12-14$.

Gennep, A. Th. G. Van (2002b). De fnedeling Mastricht: Universiteit Maastricht.

Gibbels, M. (2000). Vraagsturing in de AWBZ. Dubbele emancipatie. Zorgyise, 12, 14-19. 


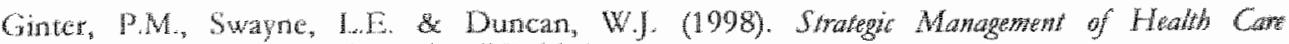
Orgatizations. Oxford: Blackwell Publishers.

Gorfman, E. (1961). Asyluzs. Ersoys an the Sodal Sitwation of Mental Patients and other Inwates. Harmondsworth: Penguin Books.

Goldstein, H. (1995). Mulhitevt statistical models, London: Edward Anold.

Goossens, F.A. \& Jyendoom, M.H. (1990). Quality of Infant's Attachments to Professiond Caregivers: Relation to Infant-Parent Atachment and Day-Care Chatacteristics. Chila Devefopmen, 61, 832-837.

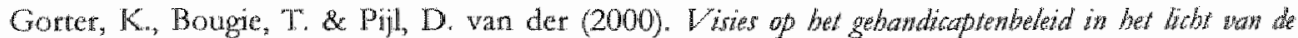
N-standardrgets. De regels ower tagandelifkehed en werkgelegenbeid. Utrecht: Kennisplationn. Gehandicapten.

Coudrialan, G. (1989). Cascmanagement: bindmiddel of breekijzer? Tydschrift woor de soutate sector, 9 , $22 \cdot 27$.

Grecnspan, 5. (1999). What is meant by Mental Retardation International Rewiow of Psydwatry, 11,618.

Grönroos, C. (1990). Service Managentent and Markering: Managyng the Moments of Truth in Serwice Conytetition. Lexingron: Lexington Books.

Grönroos, C. (1995). Relationship Marketing: The Strategy Continumm. Joursal of the Acadesy of Marketing Sciewa, 23 (4), 252-254.

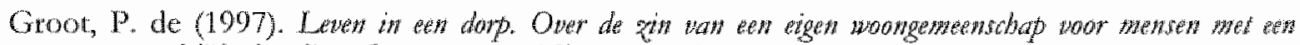
versandelije bandicat). Sappermeer: Nieuw Woelwijck.

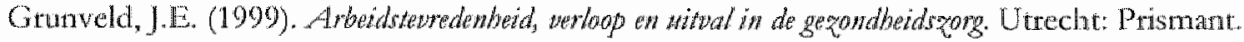

Hakker, A.A. (1993). De Vereniging Johannes-Stichting. In J. Vijselaar (Red.). Over onwozelom w

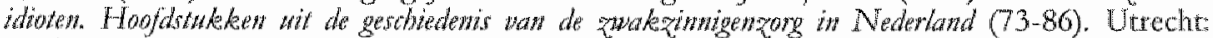
Nederlands Centrum Geestelijke Volksgezondheid.

Halbertsma, J. (1995). The ICIDH: health problems in a medical and social perspective. Disobiaty and Relabilitation, $17(3 / 4), 128-134$.

Halbertsma, J., Heerkens, Y.F., Hirs, W.M., de Kleijn-dle Vrankrijker, M.W., Van Rawensburg, C.D., \& Ten Napel, H. (1999). Towatds a new ICIDH. Disability and Rehabihtarian, 22, 144156.

Hall, J.A. \& Dornan, M.C. (1988). Meta-analysis of satisfaction with medical cate: description of research domain and analysis of overall satisfaction levels. Sortal Sciente do Medicize, $27,6 \%$. $637-644$.

Hall, P.S. Hall, N.D. (2002). Hiring and Retaining Direct-Cate Staff: Afret Fifty Years of Research, What Do We Know? Mestal Retardation, 40, 201-211.

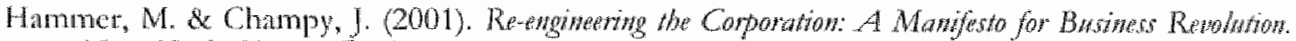
New York: Harper Business.

Hanna, M. \& Frecman, I. (1977). The Population Ecology of Organizations. Amerioun Journat of Soriolog, 82, 929-964.

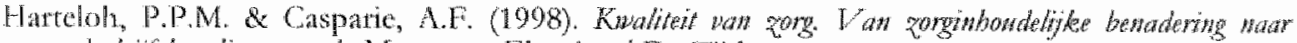

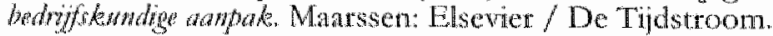

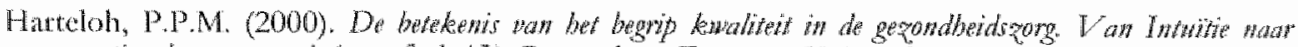

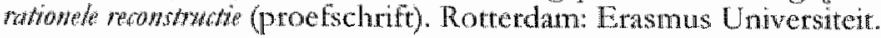

Hartine, M.D. \& lierell, O.C. (1996). The Management of Customer-Contact Service Employes: An Empitical Investigation. Joumal of Markating. 60, 52-70.

Hasenfeld, X. (1992). The Nature of Human Service Organizations. In Y. Hasenfeld (Ed), Human semper as complex organdzations (3-23). Newbury Park: Sage.

Hatton, C. \& Emerson, E. (1993). Organizational Predictors of Staff Stress, Satisfaction, and Intended Turnover in a service for People With Mulriple Disabiliries. Mental Retardation, 31 , 388-395. 
Hation, C., Emerson, E., Rivers, M., Mason, H., Swarbrick, R., Kieman, C. Reeves, C. \& Aborz, A. (1999). Factors associated with staff stress and work satisfaction in services for people

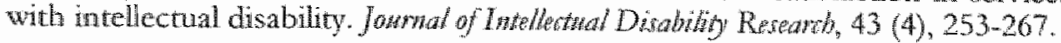

Hatton, C., Emerson, E., Rivers, M., Mason, H., Swarbrick, R., Mason, I., Kiernan, C., Reeves, C. \& Albor2, A. (2001). Factors associated with intended staff turnover and job search behaviour in services for people with intellectual disability. Joumal of Intellyctud Disabilit Rereand, 45 (3), 258-270.

Hatton, C. Emerson, E. \& Kiernan, C. (1995). Trends and Milestones. People in Institutions in Europe. Mental Retardation, 30, 132.

Hatton, C., Emetson, E., Robertson, J., Henderson, D. \& Cooper, J. (1995). The Quality and Costs of Residential Services for Adults With Multiple Disabilitics: A Comparative Evaluation. Rereamb in Developmental Disabitives, 16, 439.460.

Hatron, C.. Emerson, E., Robertson, J., Henderson, D. \& Cooper, J. (1995). An Enthotion of the

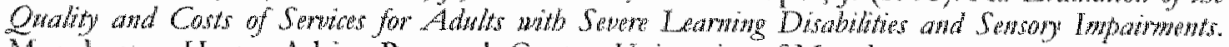
Manchester: Hestet Adrian Research Centre, University of Manchester.

Heiligers, G. (1974). Regionatisath (Beleidsnota). Heel: Stichting Sint Anna.

Heller, T., Miller, A.B. \& Hsieh, $K_{\text {w }}$ (2002). Eight-Year Follow-Up of the Impact of Environmental Characteristics on Well-Beng of Adults With Developmental Disabilities. Mental Retardation, 40(5), 366-378.

Hera, C.M. De La \& Rodriguez, F.G. (1999). The effects of member change and continuig on the productive efficiency of work teams. Psydrology in Spain, 3 (1), 88-97.

Hesket, J.L., Jones, T.O., Loveman, G.W., Sasser, W.E. \& Schlesinger, L.A. (1994). Purting the Serice-Profit Chain to Work. Hanzard Business Review, March-April, 164-174.

Heskett, J.L., Sasser, W.E. \& Schlesinger, L.A. (1997). The Semize Profit Chads. New York: The Free Press.

Hingstman, L., Kenens, R, Windt, W. van der, "Talma, H.F., Meihuizen, H.E. \& VoogdHamelink, A.M de (2001). Rappartage arbeidsmakl zorg en weloijm 2001. Tilburg: OSA

Hoeing, J. (1980). De zwakzinnigeninrichting in perspectief. Het Ziekenthuis, 7, 194-197.

Hoejenbos, E., Mast, G. van der, Schoonhovem, J.J., Smulders, F.J.H. \& Veeman, J. (1958).

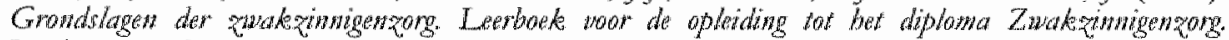
Lochem: Tipdstroom.

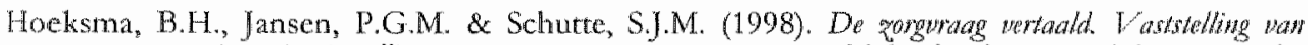

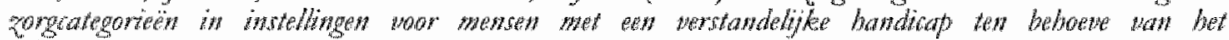

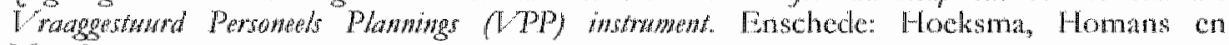
Menting.

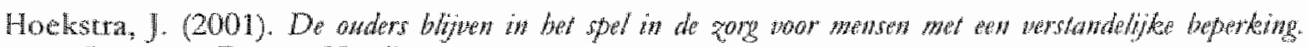
Lemmer: Bureau Kwalitas.

Hollands, L., Bergen, B. van, Degenaar, A.L., Smits, M.) \& Veen, G. de (1990). Ha wetew pas

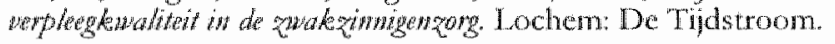

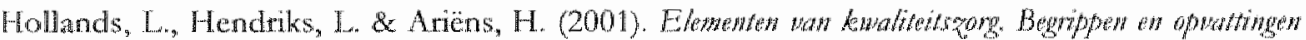
ouser fewaliteitspong. Uerecht: Lemma.

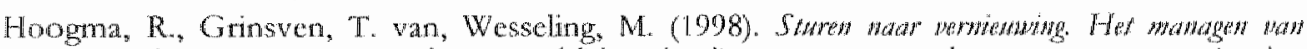

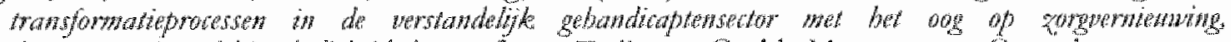
dewoncentratic en kleinsthalighedd Amersfoort: Twijnstra Gudde Management Consultants.

Horn, G.M.M.M. wen (1997). Meer dan een diagnose: de betekenis van het reforentiekader. In G.H.M.M. ten Horn, W.H.E. Buntinx, J.A.J. Coolen, E.Th. Klapwilk, W.A.L. van

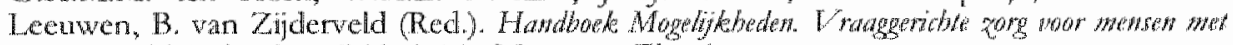

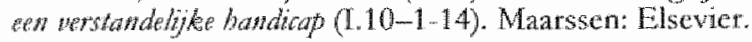

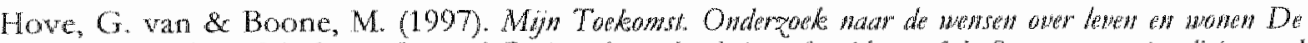

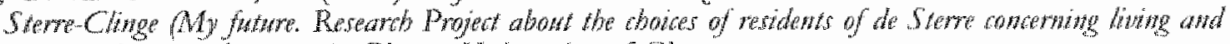
bowing) (Research repott). Ghent: University of Ghent. 
Howe, G. wan \& loon, J. wan (2003). Komen we er ooit achter wat "clienten' echt willen? In A.

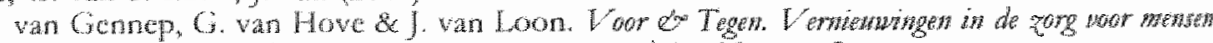
met wh wertandalife hondicats (51-70). Antwerpen / Apeldoom: Garant.

Hrchinak, I.C. \& Joyce, W.F. (1985). Organizational Adaptation: Strategic Choice and Jinvironmental Determinism. Adxamistrative Science Quaterly, 30, 336-349.

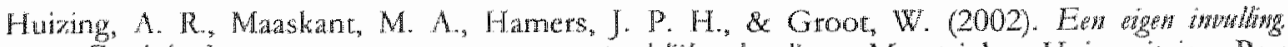

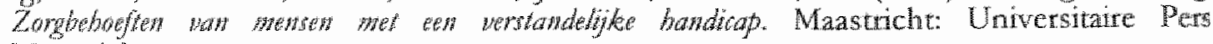
Maastricht.

Hulst, W, van (2003). Denken in competenties. Markant, 8 (7), 28-30.

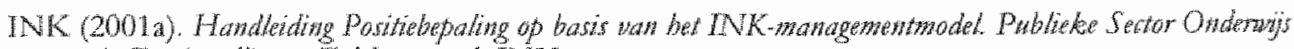

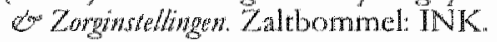

INK (2001b). Guds wor topassing udry bet INK-managenzentmodel. Zaltbommel: INK.

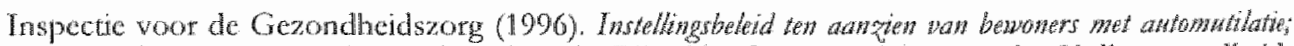

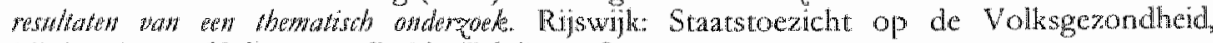
Ministerie van Volksgerondheid, Welran en Sport.

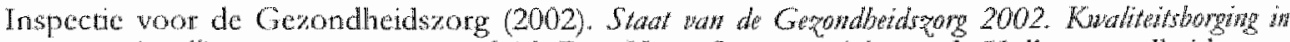

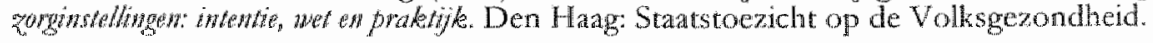

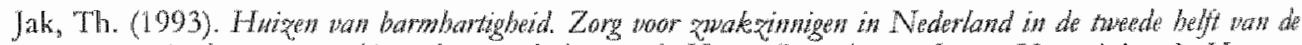

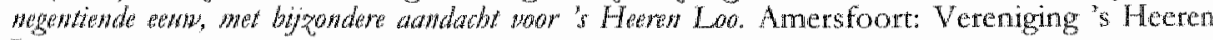
Loo.

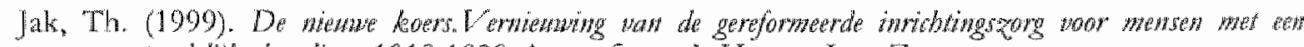
werstamdelijke bandicap 1919-1939. Amers foort: "s Heeren Loo Zorggroep.

Janssen, C.G.C., Schuengel, C. \& Stolk, J. (2002). Gedragsproblemen bij mensen met een ernstige versandelijke beperking, gehochtheidsproblemen en psychologische stress. Noderlonds

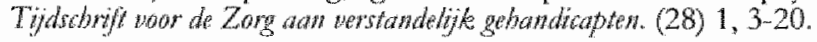

Janssen, K.G.) (2000). Consultaticteams in de prakijk. In G.H.M.M. ten Horn, W.H.E. Buntink, J A.J. Coolen, E.Th. Klapwijk, W.A.J. van Leeuwen, B. van Zijderveld (Red.). Hatodbotk

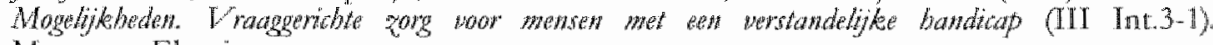
Maarssen: Ellsevier.

Jong, $A$, de (2001). Eindrappon Team Effertivituit bij Lakate Rabobanken. Maastricht: Universitent Maastrichr.

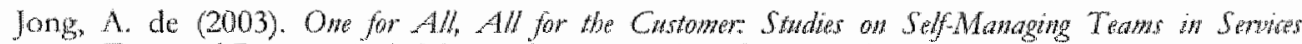
(Doctoral Dissertation). Maastricht: University of Mastricht.

Jonge, I. de \& Hamers, J.P.H. (1997). De ontwikeling en beoordeling van vragenlifsten. Forphogkisude. $12(3), 171-185$

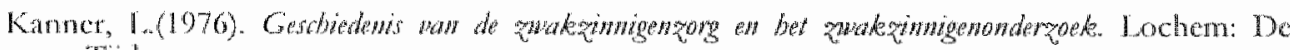
Tijklstrom.

Kaplan, R.S \& Norton, D.P (1992). The Batanced Sconcant - Measumes That Drise Performante

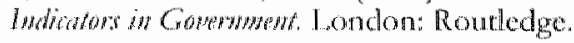

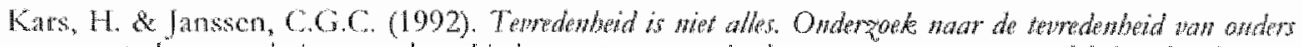

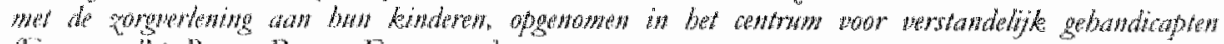

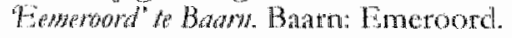

Kersten, M.C.O. \& Schuurman, M.T.M. (2000). Gebruik en mogelijkheden wan de ICIDH in de zorg an mensen met cen verstandelike handicap. Nedertands Tydschift wor de Zorg aw

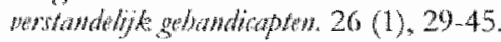

Killu, K. (1994). "The role of direct-care staff. Brharional Thtementions, 9 (3), 169-176.

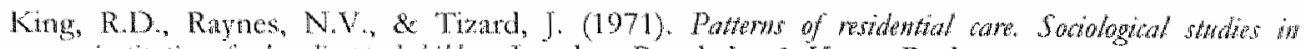
institurions for hathidrapped dsidren. London: Routledge \& Kegan Paul. 
Klijn, A. (1993). Zwakzinnigenzorg in Limburg. In Vijselaar, J. (Red.). Ower onmogelen en watom.

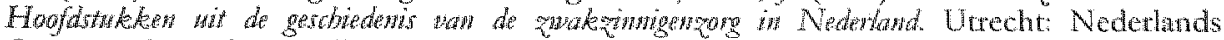
Cencrum Geestelijke Wolksgezondheid $87-116$.

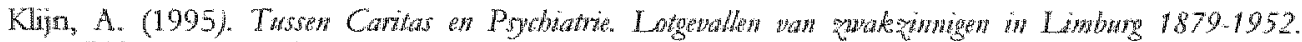
Hilversum: Verloten.

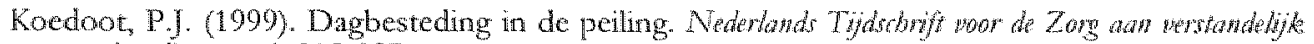
geboudicopten, 4, 215-227.

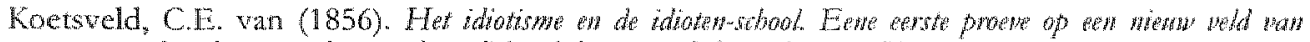
genteskesidige apwoeding an christlijke pbilantropie. Schoonhoven: Van Nooten.

Kok, J.F.W. (1991). Specifed Opwoden. Leuven/Amerstoort: ACCO.

Kok, R.). (2002). Sratistate peronelsstevte 2000. Utreche Prismant en Vereniging Gehandicaptenzorg Nederland.

Kooyman, C. (2000). 'Je hoort eigenlijk nergens bij'. Markant, 5 (juni), 18 21.

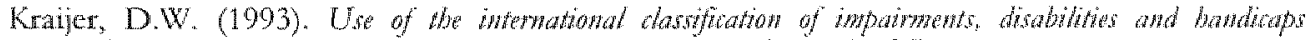
(TCIDH) in the field of memtal vedardation. Strasbourg. Council of Europe press.

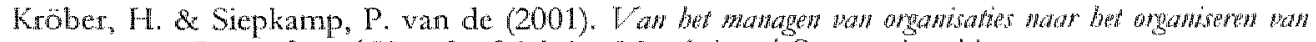
stppow. Rotterdam/Utrecht: Stichting Maskting/Companionship.

Lakin, K. (1988). Strategies tor promoting the stability of direct care staff. In M. Janicki, M.Kraus

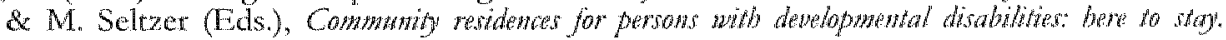
Batrimore: P.H. Brooks Publishing.

Lakin, K.C., Bruininks, R.H., Hill, B.K. \& Hauber, F.A. (1982). Turnover of Direct-Care Staff in a National Sample of Residential Facilities for Mentally Retarded People. American Jommal of Mexual Defacieng, 87, 64-72.

Iandesman, S., Dossete, E.. \& Fichols, K. (1996). The Social Ecology of Mental retardation. In J.W. Jacobson en J.A. Mulick. Mannal of Diagyosin and Professionst Practice in Mental Retardation (55 65). Washington: American Psychological Association.

landeweerd, J.A., Boumans, N.P.G. \& Nissen, J.M.J.F. (1996). De Madsinchtse Arbeidsatisfactieschad noor de Gezondbeidsoong (MAS-GZ). Maastricht: Universiteit Maastricht (Institume Health).

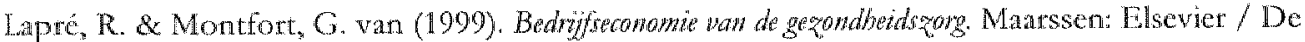
Tijdstroom.

Larson, S.A. \& Laking, Ch. K. (1999). Longitudinal Sudy of Recruitment and Retcntion in Small Community Homes Supporting Persons With Developmental Disabilities. Mendit Renoriation. 37, 267-280.

Larson, S.A., Hewitt, A. \& Anderson, L. (1999). Staff Recruiment Challenges and Interventions in Agencies Supporting People With Developmental Disabilitics. Memta/ Retordation. 37, 3646.

Jarson, S.A., Lakin, K.Ch., \& Bruininks, R.H.. (1998). Staff Recwitment and Retentions Sindy Reswhts and Interyendion Strategies. Washington: Mmerican Association on Mental Retardation.

Larsson, G. \& Wilde Larsson, B. (2001). Quality of Care and Service as Perceived by Ndults With Developmental Disabilities, Their Parents, and Primary Carcgivers. Mentat Retardatious, $39(4)$, 249-258.

Lebow, J.I. (1984). Research Assessing Consumer Sarisfaction with Mental Health Treatment: a Review of Findings. Enathation awd Progran Ptaming. 6.211-236.

Lecuwen, M. van (2004). De rol van ouders in de hulpverlening: samenwerlen als partners. In G.H.M.M. ren Horn, W.H.E. Bunnin, J.A.J. Coolen, E.Th. Klapwijk, W.A.L wan Leetwen, B. van Zijderweld (Red.). Handboek Mogelijkheden. Vtaaggeriche zorg voor mensen met een werstandelije handicap (V.8.1-1-22). Maarssen: Elsevict 


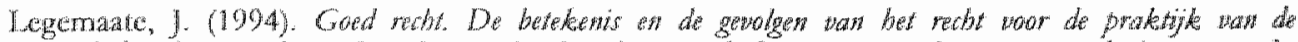
bultwhtening s.l.: Preadvies uitgebracht ten behoeve van de jaarvergadering van de Vereniging woor Gezondheidsrecht op 22 april 1994.

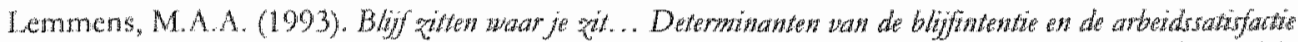

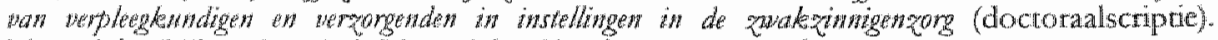
Maastricht: Rijksuniversiteit Maastricht (Verplegingswetenschap).

Lewin, K. (1935). A Dymannic Tbeoty of Persomality. Selected popers. New York and London: McGrawHij]l.

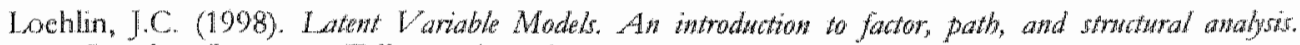
London: Lawtence Erlbaum Associates.

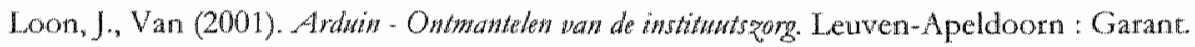

Luckasson, R., Coulter, D., Polloway, E., Reiss, S., Schalock, R., Snell, M., Spitalnik, D. \& Stark, J. (1992). Mental Retordation: Definition, Classification and Systemss of Sipponts. Washington: American Association on Mental Retardation.

Luckasson, R., Brothwick-Duffy, S., Buntinx, W., Coulter, D., Craig, P., Reeve, A., Schalock, R, Snell, M., Spitalnik, D., Spreat, S., \& Tassë, M. (2002). Mental Retardationt: Dephintiont, Classification and Syatems of Supports. Washington: American Association on Mental Retardation.

Maarse, H. (2003). Fuseren? Markednt, 8 (4), 11.

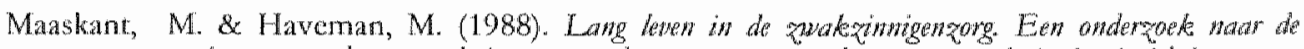

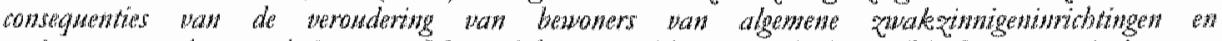
gezinswemangends tebnizen. Maastricht: Rijksuniversiteit Limburg (vakgroep Epidemiologie/Gezondheidszorgonderzoek).

Maaskant, M.A. (1993). Mental bondicop and ageing (proefschrift). Mastricht: Rijksuniversiteit Limburg.

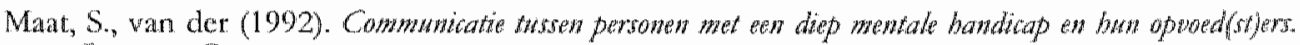
Lewven: Garant.

Maes, B. (2002). The signifucance of the relationship betneen dived support staff and persons with disabidines for their sociomemotional wellbeing. Presentation at the First European Congress of the IASSID, Dublin, June 12-15.

Maes, B., Baert, H., Moleman, C., Geeraert, I., Brucl, B. Van den \& Samoy, E. (1997). Ogg woor

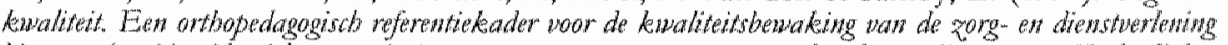

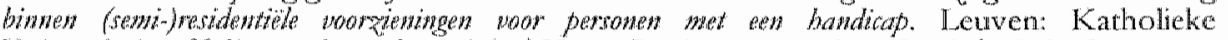
Universitcit, afdeling othopedagogiek / Hoger Instituut voor de Arbeid / LUCAS.

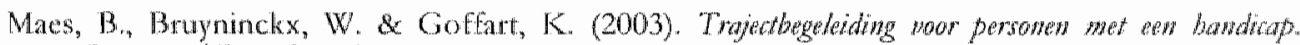
Leuven / Leusden: Accon

Macs, B. Geemert, L. \& Bruel, B. van den (2000). Developing a model for quality evaluation in

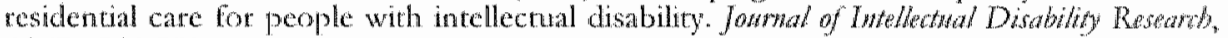
$44 \cdot(5), 544-552$.

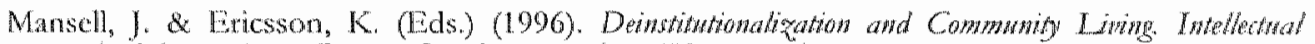
disabitiby serwides in Britain, Sandinatia and the USA. London: Chapman \& Hall.

McCormick, M., Balla, D. \&e Zigler, E. (1975). Resident-Care Practices in Institurions for Retarded Persons: A Cross-Tastitutional, Cross-Cultural Study. Amerian Jowmal of Mond Deficieng, $80,1-17$.

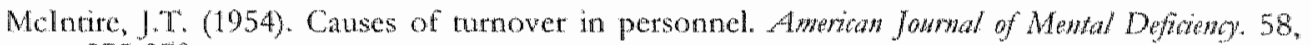
$375-379$.

McKinley, R.K., Stevenson, K., Adams, S. \& Manku-Scott, T.K. (2000). Meeting patient expectations of care: the major determinants of satisfaction with out-of thours primary medical care? Faswily Pratio, 19 (4), 333-337.

Meijer, A.W.M. (1990). Instellingen en strategisch belleid. In J.A.M. Marse \& IM. Mur-Veeman. Belead en beheer in de gerondheidsogrg (312-336). Assen: Van Gorcum. 
Meininger, H.P. (1998). Auronomie en professionele verantwoordelikheid in de zorg voor mensen met een verstandelijke handicap. Nederlawds Tigdschrift woor de Zorg ach tersicandeligk gehondiapter, $24,220-236$

Mercer, J.R. (1992). The Impact of Changing Paradigms of Disabiliny on Mental Retardation in the Year 2000. In Rowtiz l.. (Ed.), Mental Retardation in the Year 2000 (15-38). New York: Springer-Verlag.

Miller, D. \& Mintzberg, H. (1984). The Case for Configuration. In D. Millex \& P.H. Friesen, Organizations. A Quawm Viem (p10-30). Englewood Clifs (NJ): Prentice-Hall.

Ministerie van Volksgezondheid, Welzijn en Sport (2001a). Zarg aan bod. Hoofdomen wan merwiemaing wan bet zorgstelsed. Den Haag: SDU

Ministerie van Volksgezondheid, Welzijn en Sport (2002). Geoncmtrend dergwhera?

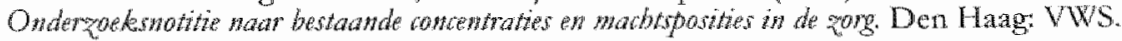

Ministerie van Volksgezondheid, Welzijn en Sport (2002). Zorgnota 2003. Den Haag: Ministetie van Volksgezondheid, Welzijn en Sport.

Minsterie van Volksgezondheid, Welzijn en Sport (2001b). Met zorg kiezex. De toerwang wan patientest consthenten in een wraggesthurde zorg. Den Haag: SDU.

Minsterie van Volksgezondheid, Welzijn en Sport (2002). Branberapport Care 98-01. Den Haag: VWS.

Minsterie van Volksgezondheid, Welzign en Sport (2003). Voortgangsapportage experiment DBC's ent inplementatie DBC's (brief dd 19.05.2003 aan de Tweede Kamer). Den Haag: WWS.

Mintzberg, H. (1983). Structure in Fines. Designing Effective Organzations.Englewood-Cliffs (NI): Prentice-Hall.

Mitchell, D., \& Braddock, D. (1994). Compensation and Tumover of Direct-Care Staff in Developmental Disabilities Residential Facilities in the United States. II: Tumover. Mental Retardation, 32, 1, 34-42.

Moen, Ph., Elder, G.H. \& Lüscher K. (Eds.). (1995). Examining Lines in Confexd. Pexspectives on the Erology of Human Dewelopwent. Washington: American Psychological Association.

Moos, R.H. \& Insel, P.M. (Eds.). (1974). Iswer in Social Ecology. Hwman Mihens. Palo Alto: National Press Books.

Moos, R.H. (1974). Eamaluating Treatment Enwionments. A Sacial Ecologial Approads. New York: John Wiley \& sons.

Mune, J., Duncan, H. \& Seymour, L. (1983). Effect of front-line staff turnover on the behavior of institutionalized mentally retarded adults. Ampricant Josmat of Mental Deficiency, 88, 328332.

Musch, C.K., Woltrerink, F.W.J.M. \& Broek, P.H.M. van den (1994). Marketing Management. Stabiliteit en Verandering. $C^{3}$ Cabier, 4(10), 1-31.

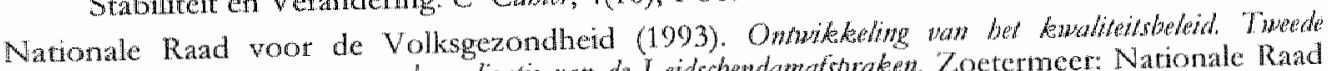

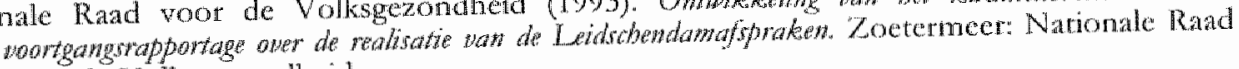
voor de Volksgezondheid.

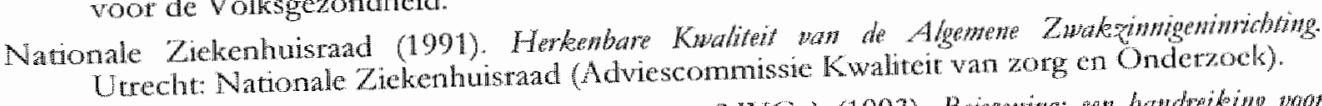

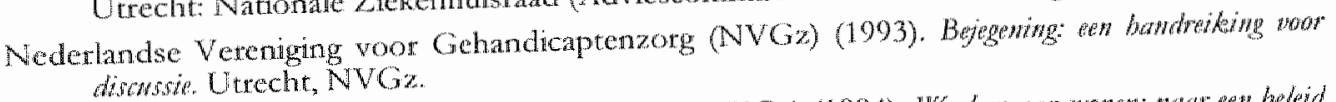

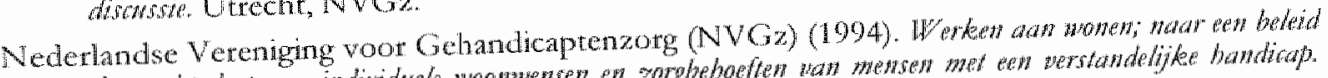

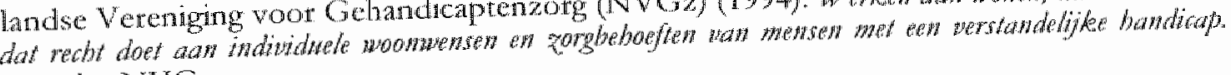
Utreche: NVGr.

Nolson, E.C., Batalden, P.B., Huber, T.P., Mohr, J.J., Godfrey, M.M., Headrick, 1. A. \& Wasson, J.H. (2002). Microsystems in Health Care: Part 1. Leaming from High-Performing FronfLine Clinical Units Jourmal on Quality Juprowement, $28(9), 472-493$. 
Nibira, K., Weisener, TS. \& Bemheimer, L.P. (1994). Ecoculrueal Assessment in Families of Children With Developmental Delays: Construct and Concurrent Validities. Amentaw Jounat on Mental Retardation, $98,551-566$.

Nivel (2000y. Terugrapportage van bet NTVEL bestemd woor de VGN. Urrecht: Nivel

NWO-Medische Wetenschappen (2001). Exteme ewaluatie en zelfewaluatie wan het NWO programsth Kwaliteit wan Zorg Onderyock (KwaZo). Den Hag: NWO.

Olson, G.L. \& Schober, B.L. (1993). The Satisfied Poor. Development of an Intervention. Oriented Theoretical Framework to Explain Satisfaction with Life in Poverty. Sordal Indicators Researth, 28, 173-193.

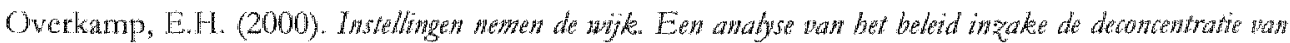

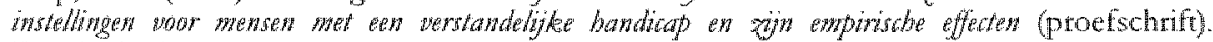
Enschede: Universiteit Twente.

Oyen, F.G.P.H. \& Schwyteneer, G.F.A. de (2002), Marketing woor de varg Maarssen: Elsevier.

Parlak, K. Lako, C.J. \& Hoogen, G.W.P. van den (2002). Klanttevredenheid over de dienstverlening bij een afdeling jeugdgezondheidszorg. Tydschrift woor Sociale Geneskende. 80 (8). $496-502$.

Pennings, J.M. (1998). Structural Contingency Theory. In P.J.D. Drenth, H. Thierry \& C.J de Wolf, Handboon of Work and Organizational Psychology (39-60). Hove (Uk): Psychology Press Ltd.

Philipsen, H. (1997). Vraaggestuurde zorg: het belang van professionele fundering wan de 'erkende vragg' natr zorg. In L. Boon (Red.). Vrauggerturde zorg. Dilemma's en mienue optites

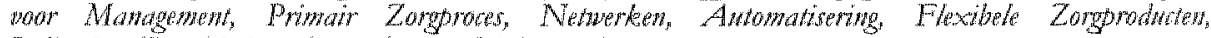
Indiatiestelling (22-27). Amstelveen: Stichting Sympoz.

Pirsig, R.M. (1974). Zen and the ant of motorgde maintenance. An inquiry iwto walues. New York: Bantam Books.

Ploeg, J, van der \& Scholte, E. (1997). Arbeidsatisfatie onder groepsieiders. Utrecht : NIZWW.

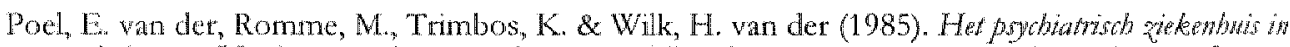

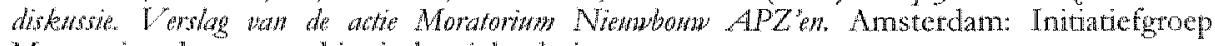
Moratorium bouw psychiarrische zickenhuizen.

Porter, M.E. (1996). What is strategy? In Harward Bassiness Renien (November-December). Boston: Harvard Business School Publishing.

Prismant (2002). Personed in Beeld. Utrecht: Prismant.

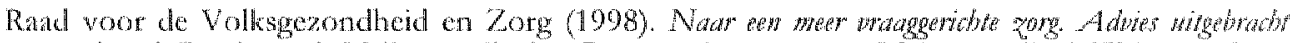

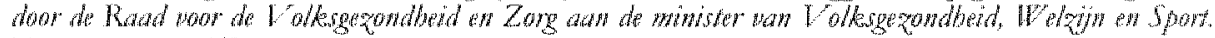
Zoetermeer: RVZ.

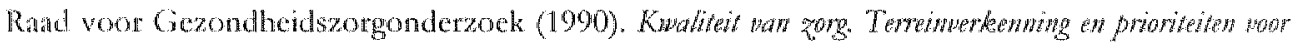
wetemblappeljk onderyork. Den Haag: Rasd woor Gezondheidszorgonderzoek (RGO).

Ratingen, J.R.M. van (1970). Problemen bij de instutionele zorg voor zwakzinnigen. Maawdodnj/ wor Kindergenterstunde, 6/7, 149-178.

Raynes, N.V., Pratt, M.W. \& Roses, S. (1979). Onganizational simcture and the are of the mentalig: marded. London: Croom-Helm.

Razza, N.J. (1993). Determinants of Direct-Care Staff Turnover in Group Homes for Individuals With Mental Retardation. Mental Retardation, 31, $284-291$.

Reindets, JS. (1999). De toekomst van de Nederlandse gehandicaptenzorg. In G.H.M.M. ten Horn, W.H.E. Buntinx, J.A.J. Coolcn, E.Th. Klapwipk, W.A.L wan Leeuwen, B. van

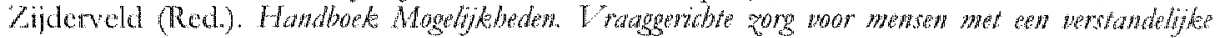
tramilitap (1.7-1-24). Maarssen: Elsevier

Reinders, J.S. (2000). Een goeie vriend is beter dan een mooi huis. In P. Ghesquiere \& J.M.A.M.

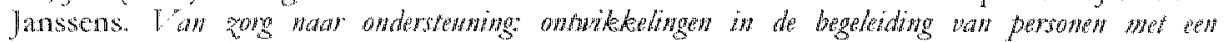
whondelfhe bandicap (19-26). Houten: Bohn Stafleu Van Loghum. 


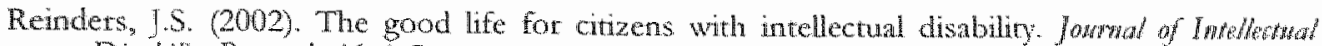
Disability Research, 46, $1-5$.

Reitsma, E \& Broek, P. van den (1999). Organisatorische kanteling in de gehandicaptenzorg. Zorg Management Magazine, 22, $18-22$.

Rioux, M.H.(1997). Disability: the place of judgment in a world of fact. fomrat of Intelleturif Disability Rerearh, Vol. 41(2), 102-111.

Robertson, J., Emerson, E., Gregory, N., Hatron, C., Kessissoglou, S., Hallam, A. \& Linehan, C. (2001). Social. Networks of People With Mental Retardation in Residential Sertings. Mental Retardation, 39 (3), 201-214.

Roelink, H.M., Pool, A., \& Grypdock, M.H. (2002). De dialoog in de zorgrelatic. Nederlands

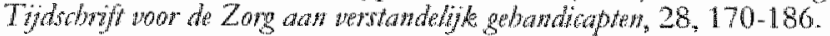

Romer, D. \& Berkson, G. (1980). Social ecology of supervised communal facilities for mentally disabled adults: II. Predictors of Affiliation Amerion Joumal of Mestal Defictency, 85, 229-242.

Ronen, S. (1978). Job Satisfaction and the Neglected Variable of Job Seniority. Fiwnan Relationi, $31(4), 297-308$.

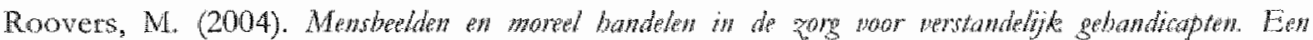
empirischethich onderack Nijmegen: Valkhof Pers.

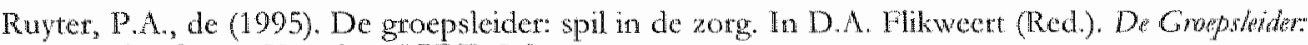
spilin de zorg. Utrecht: NGBZ, 5-9.

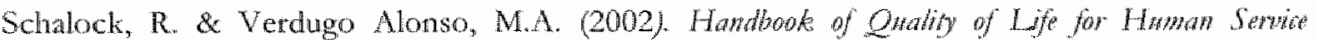
Pratitioners. Washington: American Association on Mental Retardation.

Schalock, R.I. \& Kiernan, W.E. (1990). Habilitation Planning for Aduls with Disabilities. Washington: Amenican Association on Mental Retardation.

Schartman, D. (2001). Berufliche Integration als Zone der nächsten Entwicking: Belbindertenpädagogik, 40, 35-66.

Schiesinger, L.A. \& Heskett, J.L. (1991). Bteaking the Cycle of fiailure in Services. Shat Management Ratum. Spring 1991, 17-28.

Schoggen, Ph. (1978). Ecological Psychology and Mental Retardation. In G.P. Sackett, Obserwing Behasion: Volume I. Theory and Applicationn in Mendal Rekardation. (33-62). Baltimore: Uniwersity Park Press.

Schrojenstein Lantman - de Valk, H.M.J. van, Heurn- Nijsten, E.W.A. van,

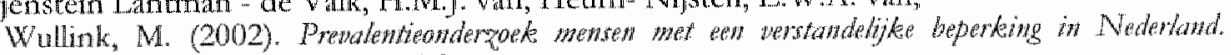
Mastrichto Universiteit Masstricht.

Schuring, G., Bamhard, M.C., Kardan, H.H., Kramer, G.J.A. \& Schoep, H.F. (1900). Emmig

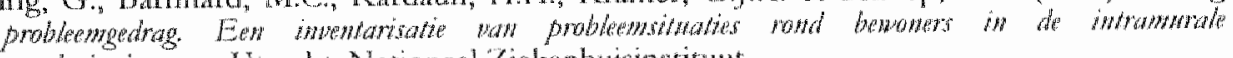
zwatequngergong. Utrecht: National Zickenhusinstimut.

Schuurman, M.I.M. (2001). Vtagggerichte zorg wan mensen met cen verstandelijke handicap: cen stand van zaken. In G.H.M.M. ten Horn, W.H.E Buntinx, J.A.J. Conken, E.Th. Klapwik,

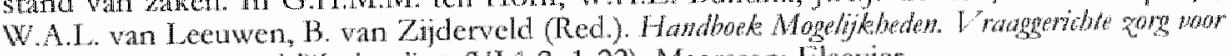

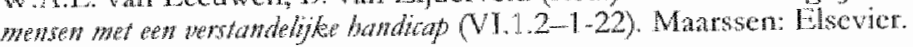

Soys, D. \& Duker, P. (1988). Effects of Staff Management on the Quality of Residential Cate for Mentally Retarded Individuals. Amerizan Jownal on Meatal Refardation, $93,(3), 290) 299$.

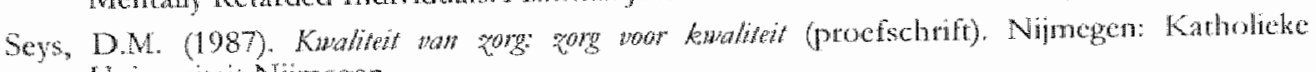
Universiteit Nijmegen.

Sixma, H. ., Campen, C. van, Kerssens, J. I. \& Peters, 1.. (1998). De QUOTE-Hragenlysten. Kwallth

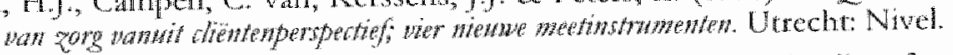

Sixma, H.]., Kerssens, J. J., Campen, C. van \& Peters, 1. (1998). Quality of cate from the paticnts' perspective: from theoretical concept to a new measuring instrument. Health Expedations. 1 . 8295 
Sluijs, E, Beck, S. van, Mouthaan, I., Neef, M. de \& Wagner, C. (2002). Verdiepingssathe

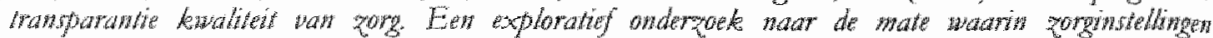

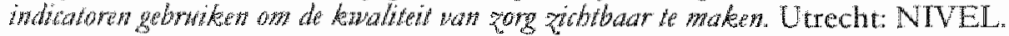

Sluyter, G.V. (Ed.) (2000). Tahal Quality Managentent in Mental Heath and Mental Retardation. Washington: American Association on Mental Retardation.

Smets, J. (2003). Hex beyt in eigen hand. Ouderinitiatieven in Noord-Brabant, Limburg en Zeeland. Tilburg: PON.

Smith, R.L. (2004). Ecology. In Engitopadia Britannica 2004 CD-ROM / DVD. Chicago: Encyclopaedia Britannica.

Sociaal en Culturecl Planbureau (2002). Rapportage gehandicapten 2002. Den Haag: Sociaal en Cultureel Planbureau.

Somma, Nederlandse Vereniging voor Gehandicaptenzorg, Fuad-Wdt \& Federatie van Oudervetenigingen (1995). Notitie wowen wan mensen met een werstandelike basdicap. Utrecht: Somma, Wederlandse Veneniging voor Gehandicaptenzorg, Fiad-Wdt \& Federatie wan Ouderverenigingen

Spanjer, M. (1997). Dynamite in steen. Utrecht: College voor Ziekenhuiswoorzieningen.

Staring, M.A.T.M., Duterloo, C.M. \& Hom, G.H.M. ten (1993). Kualitestsmeting van

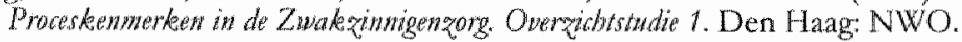

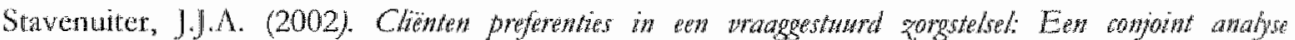
(doctoralscriptic). Maastricht: Universiteit Maastricht (Beleid en Beheer van de Gezondheidszorg).

Sterkenburg, P.S., Schneider, M.J. \& Janssen, C.G.C. (1997). Continuiteit in de zorg voor thuiswonende kindeten met een verstandelijke handicap. Nederiands Tijdschift woor de Zorg atan verstandelijls gebandicapten, 24 (4), 222-238.

Stokols, D. (1999). Human Development in the Age of the Intemer: Conceptual and Methodological Horizons. In S.L. Friedman \& T.D. Wachs, Measuring Enwionment Acoss the Life-Span (327-356). Washington: American Psychological Association.

Switzky, H. \& Greenspan, S. (2003). Can so Many Diverse Ideas be Integrated? Multiparadigmatic Models of Understanding Mental Retardation. In H. Switzky \& S. Greenspan (Eds.). What is Mental Retardation? Idtas for an Emolwing Disability (387-405). Washington: American Association on Mental Retardation.

Talbert, J.E. \& McLaughlin, M.W. (1999). Assessing the School Environment: Embedded Contexts and Bottom-Up Research Strategies. In S.I. Friedman \& T.D. Wachs, Measuring Entivonnent Across the Lifespan (197-227). Washington: American Psychological Association.

Talbot, M. (1967). Edouard Seguin. Ampercan Journat of Menal Defriewo. 72 (2) 184-189.

Thusty, M. (1992). Caregiver Network Structure, Support and Caregiver Distress. American Jonnal of Combntwity Psyology, $20,81.96$.

Test, D.W., Mlowers, C., Hewitt, A. \& Solow, I. (2003). Statewide Study of the Direct Suppott Staff Worktorce. Mendal Retandation. 41 (4), 276-285.

Teulings, A.W.M. (1993). De recalcitrante organisatie. Het draagvlak woor herstructurering en bestuntlijke vernieuwing bij de rijksoverheid. Tijdshrift troor arganisatiekstho en social beleid. 47 (5), $353-370$.

The Committe on the Quality of Health Care in America (2001). "Crosang the Quality Chasm."A new Heath Syato for the 27 . Centry. Washington D.C.: Institute of Medicine's Office.

Thompson, A.G.H. \& Sunol, R. (1995). Expectations as Determinants of Patient Satistaction: Conceps, Theory and Evidence. International Jotiral for Quality w Health Care 7 (2). 127-141.

Thompson, J. R., Hughes, C., Schalock, R. L., Silverman, W., Tasse, M. J., Bryant, B.R., Craig, E. M. \& Campbell E. M. (2002). Integrating Supports in Assessment and Planning. Mend Rutardation, $40(5), 390-405$. 
Thompson, J.R., Bryant, B.R., Camplell, EM., Crag, EM., Hughes, C.M., Rotholz, D.A., Schalock, R.L., Silveman, W.P., Tasse, M.J. \& Wehmeyer, M.I. (2004). Suppont Tntwity Scale. Users Mamal Washington: American Association on Mental Retardation.

Tizard, J. (1964). Compnution Sentes for the Mentally Handicapped. London: Oxford University Press.

Tonkens, E. (1999). Het zelfontplooingstegime. De actualiteit van Dennendal en de jaren zestig. Amsterdam: Bert Bakker.

Tronto, J.C. (1995), Van produkt naar praktik: gezondheidszotg als zorg. Rekemwap. Tydshrft woor Wetenschat en Culturt. September 1995, 148-157.

Tummers, G.E.R. Janssen, P.P.M., Landeweend, A; \& Houkes, I. (2001) A comparative study of work characteristics and reactions between general and mental health nurses: a multisample analysis. Jowryol of Advanced Nurring, 36 (1), $1.51-162$.

Tummers, G.E.R., Merode, G.G. van \& Landweerd, J.A. (2002). Organisatip, wente wh werkenties in de verpleging en weryong. Tilburg: Organisatie voor Strategisch Arbeidsmarktonderzoek.

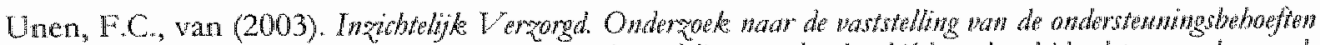

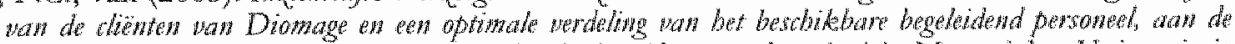
hand wan dewe onderstewningsbeboeften en bet budget (doctoraal setiptie). Maastricht: Universiteit Mastricht (Beleid en Beheer).

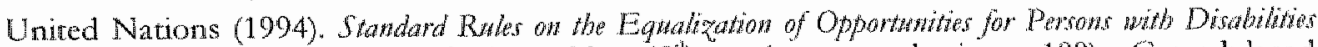
(United Nations General Assembly, $48^{\text {th }}$ session, agenda item 109). Geraadplecgd 05.05.2002, op http:/ www un.org/esa/socdev/enable/

Veen, P. \& Korver, T. (1998). Theories of Otganization. In P.J.D. Detenth, M. Thierry \& C. de Wolfe, Handbook of Work and Organizational Pyochology (5-37). Hove (UK): Psychology Press Litd.

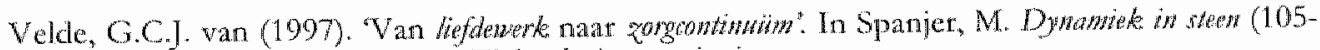
111). Utrecht: College voor Zickenhuiswoorzieningen.

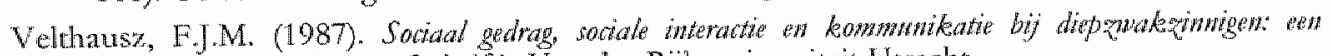
observationdergok (proefschrift). Utrecht: Rijksuniversiteit Utrecht.

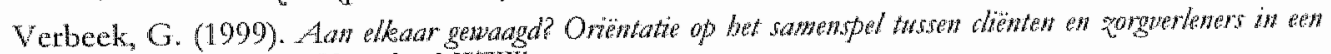
wraggenibte zong. Utrecht: NIZW.

Vereniging Gehandicaptenzorg Nederland \& Federatie van Ouderverenigingen (2002). Rrwinte mor

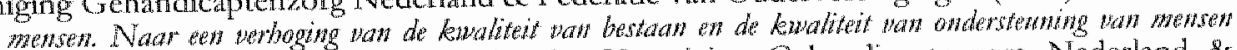
mot ennitig meerwordige beperkingen. Utrecht: Vereniging Gehandicaptenzorg Nederland \& Federatie van Ouderverenigingen.

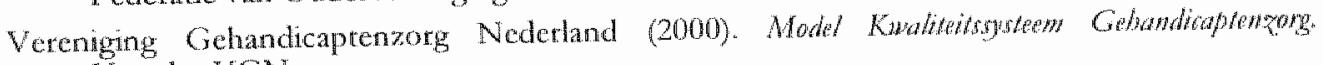
Urecht: VGN

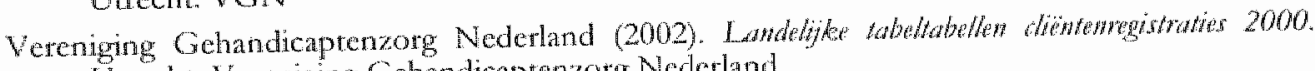
Utrecht: Vereniging Gehandicaptenzorg Nederland

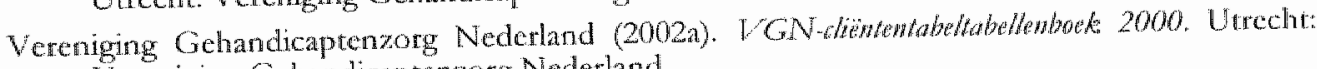
Vereniging Gehandicaptenzorg Nederland.

Vereniging Gehandicaptenzorg Nederland (2002b). Contruiteit inzet VGN bestedingsplan 2003 Sectorfonds Zotg. I GN Actuel. 6,1 .

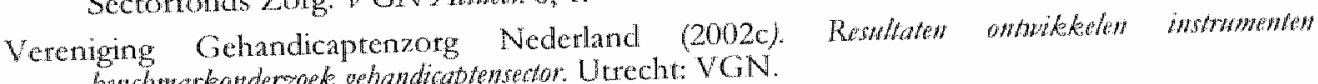

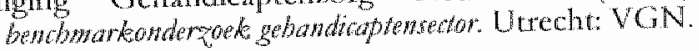

Verheggen, F.W.S. (1998). Integrale kwaliteitszorg: op weg naar cen goed geregele patientenzorg. Kanaliteit ob Zorg, 4, 155-166.

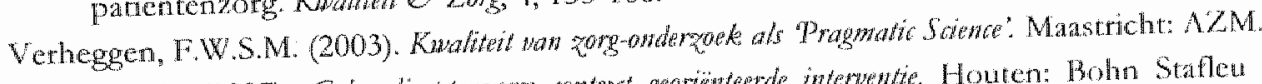

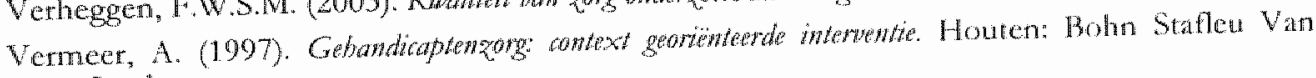
Loghum.

Verte, G.A. (1993). Honderd jaar's Heeren Loo-Lozenoond. In Vijsclaar, J. (Red.). Ower onwozeden en idoten. Utrecht: Nederlands Centrum Geestelije Volksgezondheid, 2-15. 


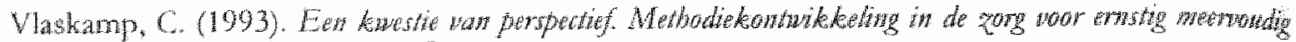
ghowdiapten. Assen: Van Gorcum.

Vlaskamp, C. \& Verkerk, M.A. (2000), Zorg als proces - over zorgpraktiken en

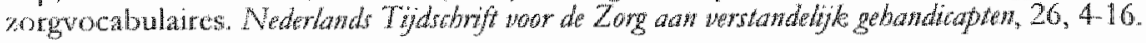

Voorberg, M. (2003j. Netwerk Kritische Ouders: Tevreden in de instelling. Ruakpun, 27, 4-6.

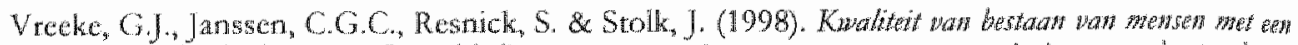

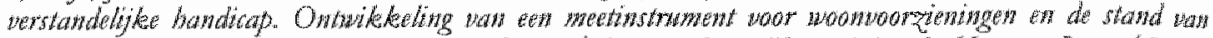
qaken in Nederlandre isstellingex. Amers foort / Amsterdam: Vereniging "s Heeren Loo / Vripe Universiteit.

Vries, W. de \& Goud, A.P.J. (2003). Strategisthe dienttremlening. 20 modellen tar ondersteming. Groningen / Houten: Wolters-Noordhotf.

Vries, W. de, Van Helsdingen, P.J.C. \& Kasper, J.D.P. (2001). Dienstemnarkering Mantagentun Groningen / Houten, Wolters-Noothof / Stenfert Kroese.

Wachs, T.D. (1999). Celebrating Complexity: Conecptualization and Assessment of the Environment. In S.L. Friedman \& T.D. Wachs, Meastumg Exwitonment Amos the Life-Spon (357 392). Washington: American Psychological Association.

WCC WHO Collaborating Center for the ICIDH) (1994). A Sumey of witum about the ICDH. Zoetermeer (Netherlands): WCC Dutch Classification and Teminology Committee for Health.

Weatherly, K.A.\& Tansik, D.A. (1993). Tactics Used by Customer-contact Workers: Effects of Role Stress, Boundary Spanning and Control. Imerwationat Jourmal of Serate Vratury Matidgement, 4. (3), 4.17.

Wetzels, M.G.M. (1998). Serwo Qualiy in Customer-Fmphoye Relationships (proefschrift). Maastricht: University of Maastricht.

Whiteman M. \& Jaskulski T. (1996). Consumer perspectives on direct support workers. In T.

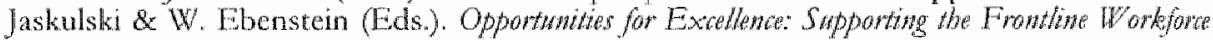
(40-55). Washington DC: President's Commitree on Mental Retardation (U.S. Department of Health and Human Serwices).

WHO-FIC Collabotating Centre (2002). MCF. Nerderlandse vertaling pan de 'International Clasification of Functioning, Disability and Headtb. Houten: Bohn, Stafleu \& Van Loghum.

Widdershoven, G.A.M. (1999). Care, cure and interpersonal understanding. Jommat of Adpaned Nuriting, $29(5), 1163-1169$.

Wierc, R. (2001). Groot, groter, groorst. Markant, 6, 20-23.

W/terma, L.A., Beumer, F.M., Koedoot, P. \& Vlaskamp, C. (2002). Dagactiviteiten voor mensen

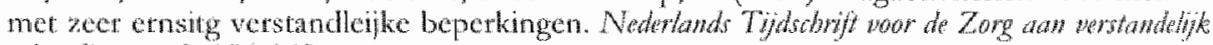
getsandicapten, 3, 156-168.

Wijk, K.P. van \& Dijk, J.K. van (2003). Vraaggerichte zorg niet zonder medewerkerstevredenheid. Zorkmangewzent, 1/2003, 2-5.

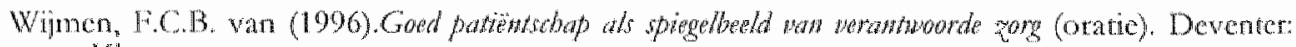
Kluwer.

Williams, B. (1994). Patient Satisfaction; a Valid Concept? Sachd Sciente Medrine, 38 (4), 509 . 516.

WOI (Landelijk Werkworband van Verenigingen van Ouders rond Internaten) (1994). Budedidader en Werleplan. Litrcht: WOT.

Wolves, M. \& Wert, A. van der (2000). Don't blame the model. De werking en werkamand

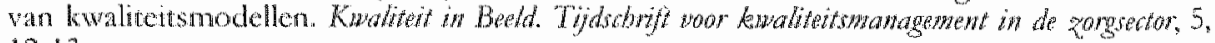
$12-13$.

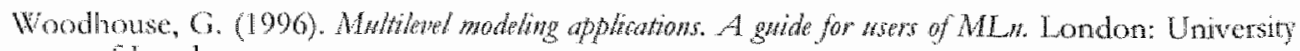
of London. 


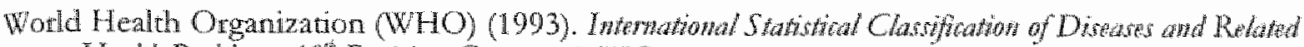
Healw Problesns. 10 Retrison. Geneva: WHO.

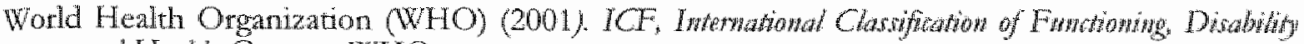
and Heath. Geneva: WHO.

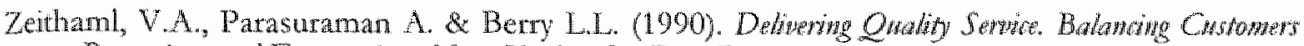
Paneptions and Expetations. New York: The Free Press.

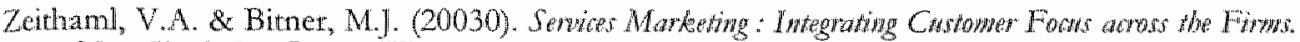
New York: McGtaw-Hill.

Zilstra, R.H.P., Vlaskamp, C. \& Buntinx, W.H.E. (2001). Direct care staff turnovers an indicator of the qualicy of life of individuals with profound multiple disabilities. Exwropen fonmal on Mental Disabiliti. Vol 22, 38-55.

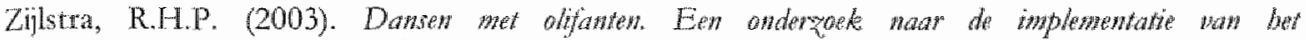

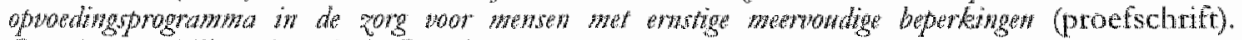
Gtoningen: Rijksuniversiteit Groningen.

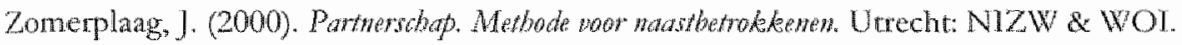

Zwan, A.A., van der, Spijker, H. \& Borssum Walkes, J.B. van (1994). Denkext over Kawaliteit. Utrecht: Federatie van Ouderwenigingen. 

Samenvatting 

Deze studie behandelt het probleem van frequente wisselingen van groepsleiders in woongroepteams van Nederlandse residentiële instellingen voor mensen met verstandelijke beperkingen. Met name wordt onderzocht wat de samenhang is tussen enerzijds aard en omvang van petsoneelswisselingen en anderzijds, organisatiekenmerken, de reameffectiviteit en de kwaliteit van de begeleiding. Het verslag van deze studie bestaat uit negen hoofdstukken.

Hoofdstuk 1 is een inleiding op het studieterrein en op de centrale problematek. In Nederland maken ongeveer 33.500 mensen met verstandelijke beperkingen gebruik van 24-uurs zorg in residentiele instellingen. De woonfunctie is nagenoeg volledig gerealiseetd in woongroepen. Aan een woongroep is een team van professionele groepsleiders verbonden: het woongroepteam. Vertrek van groepsleiders uit de instelling (door beëindiging van arbeidsovereenkomst) leidt uiteraard tot vertrek uit het woongroepteam, en wanneer vervanging plaatsvindt, tot personeelswisselingen. Maat binnen woongroepteams vinden aanzienlijk meer wisselingen plaats dan op grond van verloop kan worden verklaard. Zo zijn er tal van andere omstandigheden die kunnen leiden tot uit- of instroom vatn groepsleiders: bijvoorbeeld, door vertrek naar een ander woongroepteam binnen dezelfde instelling (job totation), door vervangingen voor ziekte of voor afwezigheid om andere redenen voor langere of kortere tijd, door tijdelijk versterking van het team, door tijdelijk 'uithelpen' in andere teams, of door opleidingsgebonden toetreding.

In de vakliteratuur klagen professionals binnen de residentiële zorg zelf, matr meer nog cliënten en hun familie, over deze personeelswisselingen die volgens hen de geleverde kwaliteit van begeleiding negatief beinvloeden. Dit gegeven vormt de beleidsmatige aanleiding van deze studie. Hoewel 'verloop' van groepsleiders in de wetenschappelijke literatuur in en buiten Nederland veel aandacht heeft gekregen, is dit niet het geval voor het verschijnsel personeelswisselingen. Dit gegeven vormt de wetenschappelijke aanleiding voor deze studie. Het doel van deze studie is: inzicht venwerven in het verschijnsel personeelswisselingen in residentiele instellingen voor mensen met verstandelijke beperkingen.

In het eerste hoofdstuk worden verder de belangrijkste begrippen gedefinicerd en wordt een overzicht en leeswijzer gegeven. De studie is opgebouwd uit twee delen. Het eerste deel betreft een algemene platsbepaling van de problematiek door middel van literatuurstudie. Deze informatie levert de achtergrond voor een empirisch onderzoek. Deel twee betreft het verslag van het empirisch onderzoek.

\section{Deel I}

De historisch-sociale schets uit boofdstute, 2 is opgebouwd rond de stelling van de structurele contingentie theorie dat de interne structurur van een organisatic begre-

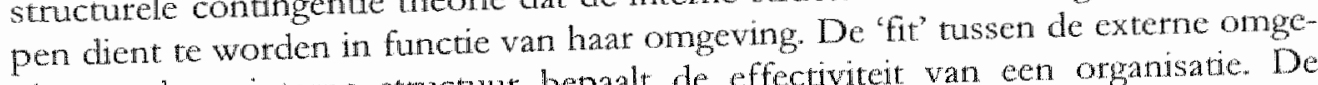
ving en haar interne structuur bepaalt de effectiviteit van een organisate. De externe omgeving van residentiële instellingen wordt beschreven in drie perioden: (1) van de $19^{\circ}$ eeuw tot de AWBZ, (2) van 1968 tot 1990 en (3) var 1990 tot 2003. 
Daabij wordt telkens ook de interne stnctuur beschreven. Her blikt dat residentele instelingen in de eerste periode relatief eenvoudige organisaties waren met stetk autonome woongroepteams die zich in de tweede periode ontwikelden tot "professionele buteaucratieen" met als doel, het bieden van een alternatieve samenlevingsvorm voot mensen met verstandelijke beperkingen. De externe ontwikkelingen in de dete periode zijn complex en cle aanpassingen van de interne organisate zijn zeker nog niet uitgckristalliseerd. Ondet invloed van deconcentratiebeleid, nieuwe regelgeving, nieuwe financieringsvormen en vooral fusies ontstaan grotere, gedivisioneerde organisaties maar ook netwerkorganisaties en virtuele organisaties. Op niveau wan de woongroepteams wordt de begeleiding meer geindividualiseerd en wordt meer andacht besteed aan methodisch werken. Dit leidt tot verkleining van woongroepen, tot veranderingen in taken (persoonlike begeleiders' doe in hun intrede in de woongroepteams) en tot individuele zorg plannen als coördinatietechnologie; het leidt niet tot veranderingen van de basisstructuur van woongroepteams. Doot verkleining van de woongrocpen onder handhaving wan een strikte koppeling van woongtoep en woongroepteam, vergroot de kwetsbaartheid van deze teams vor personeelswisselingen.

Personeelswisselingen vomen een bron van verstoting van de interne consistentie van tesidentiële organisaries en daarmee van hun effectiviteit. Dit gebeurt op de meest kwetsbare plaats voor de realisering van hun missie: in de woongtoep als interface tussen de organisatie en het clientsysteem. Het hoofdstuk eindigt met cen overzicht wan kenmerken van Nederlandse residentiële instellingen.

Hooflstuk 3 behandelt de vaklitetatuur en de wetenschappelije literatuur met betrekking tot verloop en personeelswisselingen. Uit de vakliteratuur blikt dat zowel clienten zelf, hun ouders en familie alsook professionals personeelswisselingen nadelig achten voor de kwaliteit van begeleiding. Personeelswisselingen worden gekarakteriseerd als bejegeningsproblematiek (bedreiging van wederzijds vertrouwen) mat ook als risicofactor voor het optreden van gedragsproblemen on uiteindelijk voor de kwaliteit van bestan van mensen met verstandelijke beperkingen.

In de internationale wetenschappelije literatuur is veel aandacht besteed aan vetloop. Daarbij overheerst - vooral in de Amerikaanse studies - het organisaticperspectief, gericht op behoud van medewerkers. Ook worden problemen gesignaleend in de uitkomsten van begeleiding (door personeelswisselingen geinduceerde gedragsproblemen) en in de effectiviteit van het teamfunctioneren.

Ecn systematische analyse van de (significant gebleken) correlaten van verloop en personeclswisselingen binnen tesidentiele instellingen voor mensen met verstandelijke beperkingen levert in eerste instantie éenenveertig relevante kenmerken op. Deze uitkomsten blijken te convergeren in de volgende relevante correlaten van verloop respectievelijk van personeelswisselingen: instelling; sociowoning of woning op terrein; grootte van de woongroep; zorgzwarte van de woongroep; arbeidssatisfactie; door groepsleiders ervaren participatic in besluitrorming, onderlinge samenwerking en rolduidelijkheid. Uit analyse van dezelfde wetenschappelijke literatuur worden drie typen van maten root personeelswisselingen algeleid: stabi- 
liteit van het team (type I); frequentie waarmee nieuwe teamleden instromen (type II); de gemiddelde duur van het teamlidmaatschap (type III).

Hoofdstuk 4 behandelt de factoren teameffectiviteit en kwaliteit van begeleiding. Deze hangen nauw met elkaar samen: de kwaliteit van het teamfunctioneten en de daatbij horende gunstige condities, vormen aspecten van de interne effectiviteit van de organisatie. De door het cliëntsysteem ervaren kwaliteit, vormt een aspect van de externe effectiviteit. Teameffectiviteit en door het cliëntsysteem ervaren kwaliteit vormen als het ware twee kanten van dezelfde medaille. Voor de nadere bestudeting van beide aspecten worden residentiele instellingen beschouwd als dienstverlenende organisaties met de daarbij horende kenmerken. Dit wordt uitgewerkt in de eerste paragraaf van dit hoofdstuk.

Er wordt aandacht besteed aan de begrippen vraaggetichtheid, klantgerichtheid en aan een omschrijving van 'de cliënt' in het geval van tesidentiële instellingen voor mensen met verstandelijke beperkingen. Hieruit blijkt dat ouders en familie als naastbetrokkenen en veelal ook als wettelijke vertegenwoordigers van de bewoners, belangrijk zijn voor het beoordelen van de kwaliteit van door residentiële instellingen geboden begeleiding. Na een nadere omschrijwing van de begrippen 'markt' en 'cliëntrevredenheid' wordt de relevantie van de marketingdiscipline voor de studie van het verschijnsel personeelswisselingen onderzocht. Er volgt een verkenning van de relatie tussen teameffectiviteit en cliënttevredenheid in marketingstudies. Hieruir volgt de relevantie van het marketingconcept als theoretisch kader voor de studie van personeelswisselingen.

In de tweede paragraaf van dit hoofdstuk wordt ingegaan op kwaliteitszorg. Eerst worden de vele facetten van 'kwaliteit' besproken. Vervolgens wordt een beknopt historisch overzicht gegeven van de aandacht voor kwaliteitszorg in de Nederlandse residentiële zorg voor mensen met verstandelijke beperkingen. Na cen beschouwing over het kwaliteitsaspect 'continuileit' worden personeelswisselingen omschreven als belemmerende factor voor de relationele continuiteit in medewerkercliënt contacten en daarmee voor de ervaring van de kwaliteit van begeleiding door familie van cliënten.

Hoofdrute 5 vat de conclusies uit de voorafgaande drie hoofdstukken samen. Op grond van literatururstudie en op grond van het perspectief van de kwaliteitsmarketing, worden vier relevante factoren (PW, $A, B, \& C$ geidentificeerd voor de studie van personeelswisselingen. De probleemstelling luidt: wat is de samenhang tussen enerzijds aatd en onvang van personeelswisselingen (PW) en anderzijds, organisatiekenmerken, de teameffectiviteit en de kwaliteit van de begeleiding? Bij elke factor horen deelfactoren. Dit levert de volgende uitwerking van de elementen van de probleemstelling op:

- Organisatiefactoren (op niveau van de instelling en de woongroep - $\Lambda$ ):

- Instelling als zodanig;

- Omvang van het cluster waartoe de woongroep behoort:

- Woongroep op het tertein of buiten het terrein (sociowoning);

- Grootte van de woongroep; 
- Zorgzwarte van de bewoners van de woongroep.

- Personeelswisselingen (modaliteiten van teamwisselingen - PW)

- Stabiliteit van het team;

- Frequentie van nicuwe instromers in het team;

- Gemiddelde tijd dat de teamleden deel uitmaken van het woongroepteam ("Tijd op woongtoep').

- Teameffectiviteit (condities voor effectiviteit van het teamfunctioneren - B)

- Arbeidssatisfactie;

- Rolduidelijkheid;

- Vertrouwen in eigen doelmatigheid;

- Ervaren autonomie.

- Door familie ervaren kwaliteit van begeleiding (C);

- Ervaren inhoudelike kwaliteit;

- Ervaren relationele kwaliteit.

Aan het eind van hoofdstuk 5 worden aan de hand van deze factoren en deelfactoren de onderzoeksvragen respectievelijk de deelvragen voorlopig geformuleerd.

\section{Deel II}

In boofdstuk 6 wordt de probleemstelling met de voorlopige onderzoeksvragen binnen een theoretisch kader geplaatst. $\mathrm{Na}$ een inleiding over het ecologisch karakter wan de begrippen 'verstandelijke beperkingen' en 'ondersteuning' volgt een uiteenzetting van de sociale ecologie. Uit de sociaal-ecologische theorie van U. Bronfenbrenner worden - voor de begeleidingssituatie van mensen met verstandelijke beperkingen - voorwaarden voor gunstige interacties afgeleid. Dat zijn voorwaarden die leiden tot ontwikkeling en tot beter functioneten. Vanuit een inhoudelijk perspectief wordt een theoretisch kader van interacties tussen woongroepteam, ouders en familie, en bewoners van tesidentiele instellingen geformuleerd. Vervolgens wordt vanuit marketingperspectief de interacties tussen woongroepteam en cliëntsysteem (waaronder ouders en familie) beschreven en worden voorwaarden voor gunstige interacties geformuleerd. Dat zijn voorwaarden die lciden tot grotere teameffectiviteit en in samenhang daarmee, tor grotere cliëntrevredenheid. Daartoe wordt gebruik gemaakt van een empirisch model van Hartine en Ferrell. Na een kritische beschouwing over het meten van cliënttevredenheid, worden de in hoofdstuk 5 geselecteerde factoren binnen een theoretisch kader geplaatst. Dit kader is congruent met zowel de sociale-ecologie als de marketingtheorie en is daarmee zowel inhoudelijk als organisatorisch relevant. Tot slot worden zes definitieve onderzoekswragen mer bijbehorende deelvragen geformuleerd. De eerste drie onderzoeksvragen betreffen het verband tussen personedswisselingen en (1) woongroepkenmerken, (2) teameffectiviteit en (3) door familie ervaren kwaliteit van begeleiding. Onderzoeksvraag 4 betreft het verband 
tussen teameffectiviteit en door familie ervaren kwaliteit van begeleiding. Onderzoeksvraag 5 betreft het effect van personeelswisselingen op het verband tussen teameffectiviteit en ervaren kwaliteit van begeleiding. Tot slot wordt in onderzoeksvraag 6 gezocht naar een model waarin de samenhang van woongroepkenmetken, personeelswisselingen en teameffectiviteit als voorspellers van ervaten kwaliteit van begeleiding worden gebruikt.

De deelvragen betreffen telkens de hierboven genoemde deelfactoren van woongroepkenmerken, teameffectiviteit en ervaren kwaliteit.

In boofdstuk 7 staat de opzet van het onderzoek beschreven. Het gaat om een crosssectioneel onderzoek met een exploratief katakter warbij gebruik wordt gemaakt van vragenlijsten. Het onderzoek vindt plaats bij vijf residentiele instellingen woor mensen met verstandelijke beperkingen; het totaal aantal cliènten in deze groep is representatief voor de populatie bewoners van Nederlandse algemene residentiële instellingen. Het betreft in onze onderzoeksgroep 1.813 bewoners. In dit hoofdstuk wordt de operationalisering van de onderzoeksvragen en de deelwragen toegelicht. Personeelswisselingen worden gemeten met drie maten die elk een modaliteit van de teamwisselingen meten: Stabiliteit, Instroomfrequentie en Tijd op woongroep. De teameffectiviteit wordt geoperationaliseetd door middel van vier vragenlijsten (één voor elke deelfactor). De door familie ervaren kwaliteit van begeleiding wordt geoperationaliseerd aan de hand van twee vragenlijsten (één voor elke deelfactor). De keuze voor de vragenlijsten, hun validiteit en betrouwbararheid worden verantwoord. Het hoofdstuk sluit af met de formulering van de geoperationaliseerde onderzoeksdeelvragen.

In boofdstuk 8 worden de resultaten gepresenteerd van het empirisch onderzoek waaraan 1.151 groepsleiders en 1.021 familieleden door terugsturen van hun vragenlijsten deelnamen. Data werden verzameld over personeelswisselingen en woongroepkenmerken van 188 woongroepen en woongroepteams. De omvang van de personeelswisselingen bedraagt in de gehele groep voor de Stabiliteitmaat gemiddeld 66,5 procent; voor de Instroomfrequentie-maat gemiddeld 64,5 procent; en voor de 'Tijd op woongroep'-maat 43,4 maanden. Vervolgens worden per onderzoeksdeelvraag afzondetlijk de uitkomsten gepresenteed. Bij elke declvraag wordt eerst een beschrijving van de uitkomsten van de betreffende variabelen gegeven. Dan volgt het antwoord op de onderzoeksvraag door het rapporteren van de correlaties tussen de variabelen in elke deelvraag (waar het om verbanden gaat) of van de uitkomsten van een variantieanalyse (waar het verschillen betreft). Omdat er drie maten voor personeelswisselingen worden gebruikt, wordt bij elke deelvraag het verband of het verschil getapporteerd voor elke maat afzonderlijk.

De verschillen tussen de instellingen zijn alleen significant voor de Instroomfrequentie en voor de 'Tijd op woongroep'-maat (deelvtaag 1.1). Er is een negatieve correlatie tussen de grootte van clusters en de omvang van de Instroomfrequentic en de "Tijd op woongtoep-'maat. Er is een positief verband tussen de grootte van clusters en de Stabiliteit (deelvraag 1.2). Het antwoord op deelvraag 1.3 luidt dat woongroepen op het terrein verschillen van sociowoningen op de Stabiliteit maat (ten gunste van de sociowoningen) en van de "Tijd op woongroep-'maat (ten gunste 
van de woongropen op het terrein). Verder werd een positieve correlatie gevonden tussen de woongroepgrootte en de "Tijd op woongroep-'maat (deelvraag 1.4). Er is een negatief verband tussen zotgzwaarte en Instroomfrequentie (deelvaag 1.5).

Er blikt geen werband tussen arbeidssatisfactie en personeelswisselingen: geen enkele maat leidt tot significante correlaties (deelvraag 2.1). Er is een kleine positiveve correlatie tussen rolduidelijkheid en de Instroomfrequentie van nieuwe teamleden en ook met de gemiddelde Tijd op woongroep (deelvraag 2.2). Er wordt cen positieve correlatie aragetroffen tussen de wariabele 'vertrouwen in eigen doelmatigheid' en de Stabiliteit maat respectievelijk met de 'Tijd op woongroep'-mat (deelvraag 2.3). Ook worden positieve correlaties gevonden tussen de variabele 'ervaren autonomie' en de Stabiliteit respectievelijk de 'Tijd op woongroep'-maat (declvraag 2.4).

Bij onderzoeksvraag 3 wordt het verband tussen personeelswisselingen en de door familie ervaren kwaliteit van begeleiding onderzocht. De erwaren inhoudelijk kwaliteit vertoont een kleine positieve correlatie met de 'Tijd op woongroep'-maat. De ervaren relationele kwaliteit vertoont een positieve cortelatie met de Stabiliteit mant en met de "Tijd op woongroep'-maat (deelvragen 3.1 en 3.2).

In antwoord op onderzoeksvraag 4 blijkt er een positieve correlatie te bestaan tussen arbeidssatisfactie en zowel de ervaren inhoudelijke als relationele kwaliteit van begeleiding (deelvaag 4.1). Hetzelfde beeld geldt voor de variabele rolduidelijkheid (deelvraag 4.2). De variabele vertrowwen in eigen doelmatigheid correleert alleen met de ervaren relationele kwaliteit (deelwraag 4.3). Er blijken kleine positieve correlaties tussen de variabele 'ervaren autonomie' en de ervaren inhoudelijke zowel als relationele kwaliteit (deelvraag 4.4).

Bij onderzoekswraag 5 wordt gekeken naar het effect van personeelswisselingen op de correlaties tussen de teameffectiviteit en de door familie ervaren kwaliteit van begeleiding. De tesultaten van de regressieanalyses naar interactie-effecten laten zien dat de omrang wan de stabiliteit wan het team een effect heeft op de grootte wan de correlatie tussen arbeidssatisfactie respectievelijk roldwidelijkheid en de door familie ervaten relationele kwaliteit van begeleiding. We noemen dit een sensibiliseringseffect: bij ongunstige stabiliteit is er een hogere correlatie tussen arbeidssatisfactic respectievelijk rolchidelijkheid en door familie ervaren relationele kwaliteit van begeleiding.

Bij onderzoeksvraag 6 wordt gezocht naar een model van samenhang tussen alle variabelen van de factoren woongroepkenmerken, personeelswisselingen, teameffectiviteit als voospellers van doot familie ervaten relationele kwaliteit van begeleving. Hierbij blikken directe significante paden te worden gevonden met arbeidssatisfactie en 'Tijd op woongroep'. 'Tijd op woongroep' vertoont een significant positief verband net arbeidssatisfactie. Woongtoepgrootte, zorgzwaarte en clustergrootte blijken voorspellers te zijn van 'Tijd op woongroep'. Er wordt een marginaal significant rechtstreeks pad aangetroffen van clustergrootte naar ervaren relationele kwaliteit van begeleiding. 
In hoofdstuk 9 worden de conclusies geformuleerd. Algemeen kunnen personeelswisselingen worden beschouwd als belemmerende factoren voor zowel teameffectiviteit als door familie ervaren kwaliteit van begeleiding. Dit effect is echter sterk afhankelijk van de beschouwde modaliteit van personeelswisselingen die op hun beurt afhankelijk zijn van organisatorische kenmerken.

$\mathrm{Na}$ een aantal kritische methodologische kanttekeningen volgen drie inhoudelijke beschouwingen. In de eerste plaats wordt - in het belang van teameffectiviteit en kwaliteit van begeleiding - het belang onderstreept van het monitoren van de teamstabiliteit en het nemen van maatregelen wanneer deze bedreigd wordt: deze matregelen dienen de vertrouwensrelatie tussen organisatie en familie te ondersteunen. In de tweede plaats dienen door de organisatie zelf geïnduceerde wisselingen in relatie tot tijdelijke vervanging van teamleden klein te wotden gehouden; dit kan door vervanging zo dicht mogelijk bij het team te organiseren met medewerkers die met cliënten, collega's en werkwijzen van het team bekend zijn. In de derde plaats blijkt de 'gemiddelde tijd op woongroep' de belangrijkste continuïteitsmaat, en in het kader van door familie ervaren kwaliteit van zorg, een relevante kwaliteitsindicator te zijn.

Het hoofdstuk sluit af met aanbevelingen voor het kwaliteitsbeleid, voor de beheersing van incidenten (discontinuiteit) van woongroepteams en voor het strategisch beleid van residentiële instellingen. 

Summary 



\section{Continuity of Care}

A study of the relations between direct service staff continuity, organizational characteristics, team efficacy and family perceived service quality in Dutch residential facilities for persons with intellectual disability.

Chapter 1 introduces the central problem of the present research ptoject: the continuity of residential care for persons with ID in the Netherlands. The reason for the project are the repeatedly expressed concerns and complaints by clients, clients' families and professionals about frequent changes of direct service staff (DSS) in residential service teams. A residential service team is a group of direct care employees that offers practical and daily face-to-face support to a group of dients sharing the same residential setting (e.g. a group home or a living unit). The stability and continuity of these DSS teams are pivotal to the quality of care that clients actually are receiving.

Although research projects on DSS rurnoter in residential facilities for persons with intellectual disability (ID) are well documented in the literature, research on changes of DSS tean membership within the primary residential service teams is hardly available. Although DSS turnover of course is reflected in DSS team membership changes, the latter are subject to additional pressures and should be seen as the result of the combined effects of turnover as well as of transfers, temporary assignments, internships, relief of staff within the same company and changes for reasons of human resources management. Some authors suggest that the rates of DSS changes at the level of direct service teams might be substantially higher than turnover rates at the level of the organization as a whole (the usual level for turnover studies). However, hardly any empirical evidence exists as to the size and impact of these team membership changes (Baumeister et al., 1987; Braddock et al., 1992).

This study aims at clarifying the size and the impact of DSS team membership changes in Dutch residential facilities. The central question of the study is the relation between DSS team membership change rates and $(A)$ the organizational context of the residential living group, (B) DSS team efficacy and (C) quality of care from the client perspective. To answer this central question, a study of the literature is first conducted to describe the context of the problem, to identify relevant correlates of DSS changes in residential service teams and to explore relevant theoretical frames for the study of this problem (part I). Second, an empirical study is conducted to investigate the relations between DSS changes and three groups of variables: organizational characteristics, team effectiveness and perceived quality of care (part II).

\section{Part I Context and relevance}

Chapter 2 offers an historical review of organizational characteristics and DSS rurnover in residential facilities for persons with ID. It is demonstrated that 
turnover has been a problematic feature of professional residential care ever since its origins in the last 25 years of the nineteenth century. The organizational structure of these facilities in the Netherlands varies as a funcion of to the changing bureaucratic environment moving from 'simple" organizations (1875 1950) to full "professional bureaucracies" $(1950$ - 1990) and recently showing a tendency towards 'network organizations' (1990 - present). However, the basic arrangement of the residential 'service encounter' - despite changes in group size reduction and team functions (e.g. the introduction of case management based DSS tasks) - has always been the linkage of one specific DSS team to one specific setting of clients. When in time average residential group size dropped (from $15-$ 20 before 1968 to $8-9$ in 2001), team size consequently was also reduced. This led to smaller DSS teams that became more vulnerable to changes due to turnover, but also to DSS replacements (whether or not temporarily) and transfers within the same organization. Historical studies relate turnover to the social status of the profession, labor market circumstances and also to cultural factors such as the custom of Dutch women to stop working when they married (first half of the $20^{\text {th }}$ century) or the vast and stable workforce of religious nuns and brothers in the residential care for persons with ID, particularly in the South of the Netherlands between 1879 and 1950 . There are no historical studies of DSS team membership changes.

The present Dutch residential care for persons with ID comprises 133 different facilities serving 33,694 clients and employing a workforce of 54,020 individuals (of which 45,219 DSS). The average age of the residents is 38 years ( $8 \%$ older than 65 ); in terms of the traditional 'levels of functioning', the residential population of persons with ID can be characterized as having mild (12\%), moderate $(33 \%)$, severe (31\%) and profound (24\%) intellectual disability. Although Dutch residential care up till the 1990 's could largely be labeled as congregate on campus institutional care, a significant proportion (over $35 \%$ ) of the clients is now living 'off campus' in community based group homes and apartments. Both on and off campus groups still function under the same administration and governance body. This shift should therefore be seen as a process of institutional transformation and deconcentration tather than de-institutionalization.

Chapter 3 offers a systematic review of the professional as well as of the scientific research literature to (1) document the relevance of the phenomenon of frequent DSS team membership changes, (2) to identify correlates of DSS turnover and team membership changes and (3) to identify operationalizations of 'DSS team membership changes'.

(1) The relevance of DSS changes is overwhelmingly documented in the professionall literature. Clients, families of clients as well as professionals complain about both the extent of DSS team membership changes in practice and about the persistency of the problem despite repeated calls for attention by parents associations. All televant stakeholders consider frequent. DSS changes as a serious quality of care risk and even as a bartier for the quality of life of persons with ID in 
long term care and especially in residential care. Frequent. DSS changes are believed to have a negative impact on the client's attachment to significant persons in his immediate environment and to the client-DSS communication. Frequent DSS changes are seen as a hindrance to getting familiar with the client's needs, to developing adequate responsiveness of care workers and to building the necessary trust for personal support. For the organization, frequent DSS team changes negatively affect the client's and families' consumer trust. For care and support companies, DSS changes therefore are both a strategic and quality issue.

(2) Although the 'theory of membership dynamics' of Arrow and McGrath (1995) includes 'temporal patterning of member changes' as a variable, there are no empirical studies on team dynamics and member changes available that are relevant to long term care situations. On the other hand, there are several international studies on DSS turnover. A review of these studies lead to the identification of 41 relewant otganizational correlates (Table 3.1). Because DSS changes in residential teams appear to be significantly affected by intra-organizational factors, a selection of such correlates was made on the basis of empirical research evidence. This eventually resulted in five characteristics of the organizational team context (factors: facility, living group size, on versus off campus living group, cluster size (number of teams congregated in the same higher otganizational grouping) and intensity of clients supports needs in the living group) and four team characteristics (factors: DSS job satisfaction, perceived autonomy, work stress and role clarity).

(3) Exploration of empirical literature unveiled fourteen different approaches to the measurement of turnover. Analysis and transposition of these measures into DSS team membership change measures resulted in three distinctive measurement types: team stability (STAB) reflecting team continuity based on the proportion of team membets than are still on the team after a period of one year; admission rate of new members (INFR) reflecting team discontinuity based on the number of new team members that strcam into team over a one year period, regardless of the purpose or length of their membership (temporary relief or replacement); and

average length of team membership reflecting the average length of service of all members of a particular team (TOWG).

Since continuity, discontinuity and length of team membership represent different dimensions of team changes (Arrow et all, 2000) and because of Braddock and Mitchell's recommendation (1992) to using mote than one measure (in turnover studies), the three types of measures will be retained for further operationalizations and use in this study.

Chapter 4 is an exploration of relevant contexts for the study of DSS team membership changes. The first section of this chapter deals with tesidential care for persons with ID as 'services'. The purpose of the service is to satisfy client needs. The DSS team is at the centre of the service encounter between the facility and its clients. DSS team efficacy and client perceived service cuality ate closely linked and can be seen as two sides of the same coin. Therefore, it would be relevant to sndy 
the impact of DSS team membership changes on both team efficacy factors and client percerved quality of the serwice.

It is argued that service matketing offers a relevant frame for the study of DSS changes impact on both team efficacy and quality output. Hartine and Ferrell's ampirical model for the management of customer-contact service employees (1996) presents an organizing frame for DSS team efficacy characteristics as explored in chapter 3. Gröntoos' model of customer perceived quality (1990) presents a frame for the conceptualization of client perceived quality in two dimensions: technical quality (content related) and functional quality (related to the DSS - client relationship). It is argued that in services for persons with (severe) ID, the client system (person with ID and his or her family and social network) should be conceived as the extended client. Family perceptions of quality of care therefore are relevant indicators of the organizational outcome.

In the second section of this chapter, the service marketing approach is situated within quality management models that are frequently used in the Dutch residential services industry (1.e. the Eutopean EFQM Excellence model and the MKG quality system of the Dutch association of JD service providers).

Chapter 5 summarizes the results of the three previous chapters and offers a preliminary organization of rellevant correlates of DSS membership changes within a general theoretical model (figure S1).

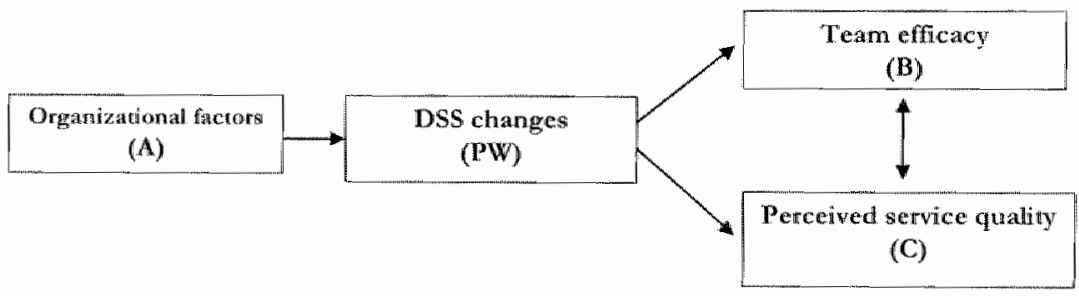

Figure \$1. Gereral theoretical model

Organzational fators (A): facility in general, size of DSS team cluster, on / off campus living group, living group size, and living group intensity of supports 5 factors).

DSS toan wewbership banges (PV): team stability (STAB), admission rate of new nembers (INFR) and average length of ream membershp (TOWG) (3 measures). Team efforg (B): job satisfaction, role clatity, self-efficacy rating and empowerment as four tean efficacy conditional factors (4 factors).

Family peroined service qualib (C): technical quality and functional quality (2 factors).

Chapter 5 also formulates the preliminaty research questions. 


\section{Part II Empirical study}

Chapter 6 deals with the underpinning of the preliminary theotetical model. First, intellectual disability is explained as the expression of limitations in individual functioning within a social context. The contextual nature of human functioning offers the theoretical basis of supports. Characteristics of the person's environment are closely related to the quality and impact of supports. Continuity of the microcontext and especially of the relarionship between the disabled person and his support providers are defined as critical to the quality of supports and hence of the funcrioning of persons with ID. The social-ecological theory of Bruno Bronfenbrenner offers a number of statements that are directly relevant to the continuity of micro-context supports and apply to both the living group and the family context as well as to their mutual relations. Social-ecology therefore serves as a basis for the theoretical underpinning of the research model. Within this theory, discontinuity of DSS membership is a batrier to the functioning of persons with ID, both directly (through relationships of residents and DSS) and indirectly (through relationships between DSS and residents' family). Second, the empirical model of Hartline and Ferrell is further explored. It is argued that this model is compatible with Bronfenbrenner's social-ecological statements. Hartline and Ferrel's model explains the relations between efficacy conditions for service teams and customer perceived quality of the service. DSS changes can be conceived as impeding factors for both team efficacy and client system quality perceptions.

Third, to validate the method for measurement of quality perceptions some theoretical problems of conceptualizing and measuring customer satisfaction and family quality perceptions in residential care are discussed. Finally, the specific research questions ate articulated and situated within the validated research model. Each research question will be answered separately for each of the three DSS measures.

What is the relation between organizational characteristics (5 factors) of residential services and DSS team membership changes?

What is the relation between DSS team membership changes and ream efficacy ( 4 factors)?

What is the relation between DSS team membership changes and family perceived service quality (2 factors)?

What is the relation between team efficacy and family perceived service quality?

Do DSS team membership changes affect the relation between team efficacy and family perceived service quality?

Can an empirical model be constructed of the 5 organizational factors, the 3 DSS team membership changes measures and the 4 efficacy factors to predict family perceived service quality ( 2 factors)?

Chapter 7 describes the research design (explorative cross-sectional) and the operationalizations of all factors and DSS change measurements into researchable 
variables. The validity and reliability (Table 7.2) of scales and measurements are discussed. Two questionnaires were conceived: one for a DSS survey (comprising 4 team efficacy measures) and one for a clients family survey (comprising 2 quality measurements). Data on organizational characteristics and of DSS changes were retrieved from the facilities administrative databases. Research questions are analysed either in terms of variations (ANOVA) or correlations and multiple (hierarchical) regression (after a test for hierarchical structure of the data). Research question 6 is answered through path analysis (following an analogous procedure as used by Hatton et al., 1999 \& 2001). The research population consists of five Dutch residential facilities ( 1,813 clients); their characteristics in relation to the characteristics of the national population of residential facilities are described (Table 7.1). This chapter concludes with reformulating the six reseatch questions and their subquestions (considering specific factors) in their operationalized formars.

Chapter 8 presents the results based on 1,151 returned DSS surveys (65 percent) and 1,021 returned family surveys ( 60 percent). Results are based on clata from 188 living groups and 188 DSS teams respectively. Before the research questions are answered, an overview of DSS team membership changes is presented according to the three measurement types (Table 8.1). Over all team stabitity (STAB) in the 188 DSS teams is 66.5 percent of actual team size ( $S D=21.5$ ); reversibly, this means an average instability of 34.5 percent. Over all num admissions (INFR) as a measure of team discontinuity ate 64.5 percent of actual team size $(S D=48.8)$, meaning that in a team of 10 DSS on the average 6.4 new 'faces' are introduced to the residents within a one year period. It should be noticed that the average DSS turnover in all five facilities is 1.4 .1 percent. Over all length of serwice for DSS in their present teams is 43.4 months ( $S D=28.3$ ). Results show considerable variation and a wide range for all measures. Multilevel analysis showed that 92 percent respectively 86 percent of the variance of the perceived quality variables is accounted for on the team level; cluster and facility level yield no significant proportion of the variance. It was therefore decided to apply ANOVA, correlation and regression techniques. The results can be summarized as follows (Table $\mathrm{S} 1 \mathrm{a}, \mathrm{b}, \mathrm{c}$ ): 
Table Sla Summary of results for research questions $1,2,3$, for each DSS change mexsure (STAB, INFR TOWGI. $\mathrm{N}=188$ DSs teams.

\section{Rescarch question \\ and subquestion}

1. Relation berween organizational characterstics and PW
1.1. Faciling
1.2. Ouster size

1.3 On/off campus

1. Al Iiving group size

1.5 Intensity of supports

DSS team membership changes $(P W)$
measures

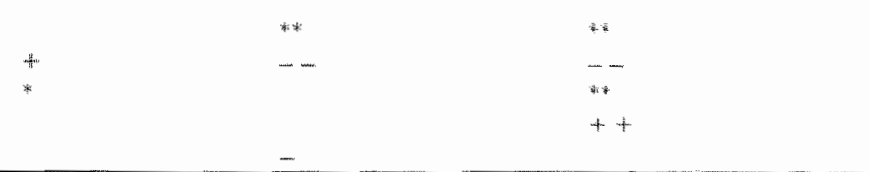

2. Relation between effrcacy
2. Iob sacisfaction
2.2 Role dariry
2.3 self efficacy rating
2.4 Empowerment

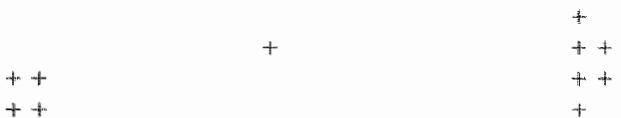

3. Rebation beween PW and family

percenwed strvice quality

5. 1 technichl qualing (conment)

32 functional qualicy (relations)

$+$

+1

"Tabulle S1b Summary of results for research questions 4 \& 5, for each DSS change measure (STAB, INFR \& TOW $\mathrm{G}$ ) $\mathrm{N}=188 \mathrm{OSS}$ reams.

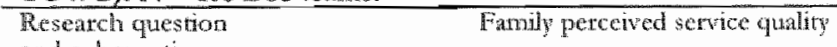

and subquestion

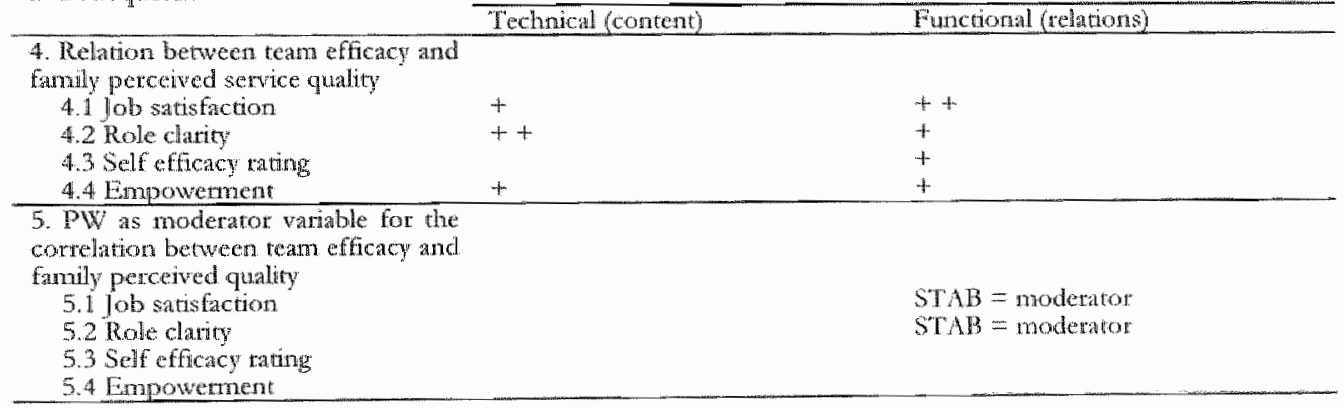




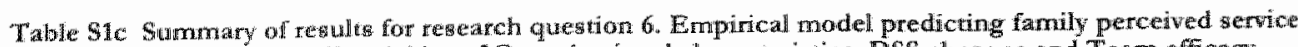
quality (functional) from all wariables of Organizational characteristics, DSS changes and team efficacy. $N=180$ DSS

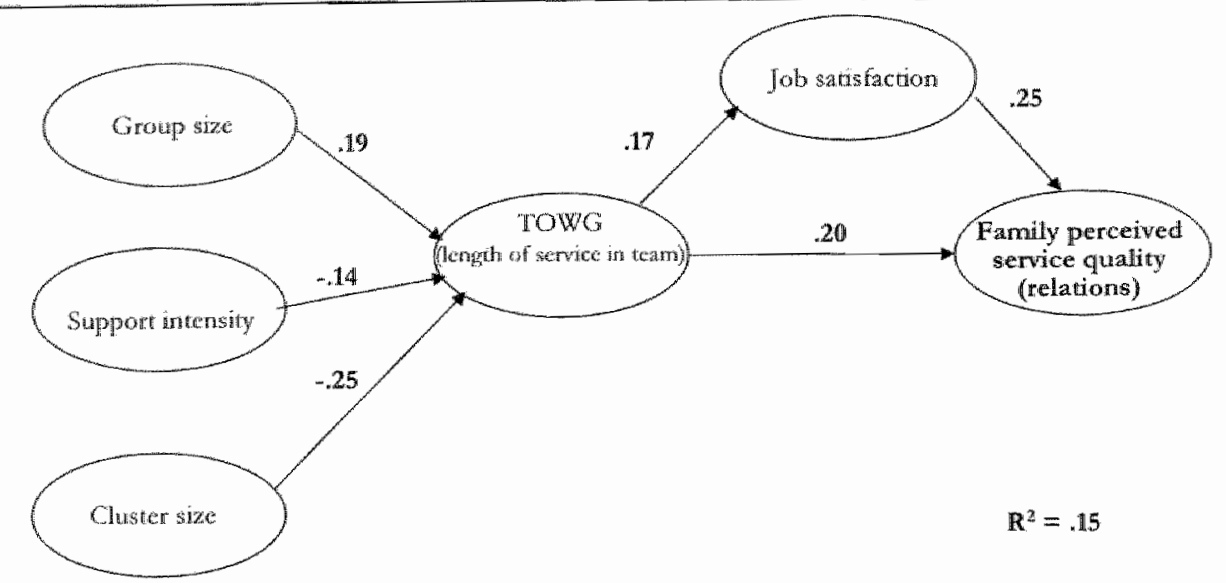

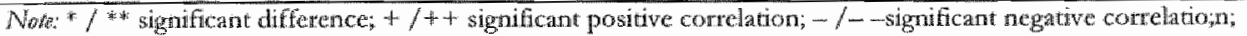
$* /+1-=p>05 * * /+1 /-\ldots-p>01$

Chapter 9 offers the conclusions and a discussion of the results. It is concluded that in all facilities the size of DSS team membership changes is considerably higher than the turnover at the general facility level. For quality of care studies as well as for management practices this is an important outcome since tumover measures clearly underestimate the actual amount of DSS changes at the level of the service encounter and consequently its impact on quality of care.

Facilities do not differ on the STAB measure. Stability seems closely associated with turnover. They do differ though on the INFR measure that more reflects inrernal staff replacement and transfer practices as well as on the TOWG measure representing the average length of service in the team. Larger living group size and larger cluster contexts appear favorable conditions with respect to DSS changes; small living groups and small clusters (i.e. of relatively few teams) are associated with higher DSS changes.

TOWG or length of service in the team is clearly positively correlated with the efficacy measures of job satisfaction, role clarity, self-efficacy rating and empowerment of the team. Stability is positively correlated with self-efficacy rating and perceived empowerment of team members.

The same positive correlation is found between TOWG and both the technical and functional family perceived quality of care. Team continuity is positively associated with family quality perceptions. The same association is found between all fout team efficacy factors and family perceived functional quality. This result reflects a 'mirror effect' between staff job satisfaction and clients satisfaction with services: high job satisfaction is associated with high customer satisfaction, although no causal effect can be concluded from our data and - in the perspective of the literature (Schneider et al., 1998) - an interactive effect is more probable. 
Team stability (STAB) is a moderator of the relation between the effrcacy factors job satisfaction and role clarity on the one hand, and functional perceived quality on the other. This implies that team stability is a sensitizing factor for the relation between team efficacy and perceived quality: low stability is associated with high correlation between team efficacy measures (job satisfaction and role clarity) and perceived functional quality; high stability is associated with low correlation between these factors. In instable teams or relatively new teams, the mirror effect seems to be stronger.

Path analysis shows that the best prediction of family perceived functional quality is obtained by a combination of job satisfaction, length of service in team (TOWG) living group size, cluster size and intensity of supports as shown in Table S1c. It should be noticed that a direct positive path between cluster size and family perceived service quality appears also highly probable $(p=.067$; see Table B8.11). This is consistent with the conclusion that larger team and cluster size are associated with favorable (lower) DSS team membership changes.

The discussion of the results starts with the limitations of this specific research project. There are several critical remarks that should be considered. (1) Only five Dutch facilities out of 133 were included in this project; this was not an ad random selection although the population characteristics (level of functioning and age) of the five facilities are representative for the national population of resiclential clients. (2) Although relations between DSS changes and other variables were studied, no causal effects can be concluded from this cross-sectional study. (3) All analyses were conducted at the team level, meaning that all individual data were aggregated to the team level. This accounts for a loss of variability at the individual level. However, DSS is a team phenomenon and a combined study of DSS team efficacy factors and client system outcome necessitates the aggregation of data. Nevertheless, the same data are open to separate analyses within the scope of DSS efficacy factors or the family quality perception factors.

The discussion concludes with recommendations for research and practice.

The following recommendations are made:

\section{Research}

Research with respect to the impact of staff turnover on organizational processes (such as team efficacy and efficiency) and outcome (such as team petformance measures and benchmarking) should also pay attention to actual team membership changes as a separate factor.

There is a remarkable compatibility between social-ecological theory of human functioning and service marketing theory and models. This compatibility is rooted in the service dyads of staff-client interactions at the level of the service encounter. Reseatch on quality performance of professional support services in health care should benefit from this compatibility to enhance validity and relevance. 
Research on efficacy and quality outcome of DSS teams in services for persons with ID should benefit from the body of theoretical and empirical knowledge of the service marketing discipline.

\section{Practice}

DSS team membership stability and discontinuity are quality indicators and should be addressed in health cate quality policy and practice.

Replacement of DSS (e.g. to relieve colleagues on sick leave, vacation et cetera) should be organized as close to the primary team as possible (and not from remote pools of relief staff).

If frequent or substantial DSS changes in a particular team can not be avoided, special attention should be given to maintaining positive relations with the client families (e.g. more frequent meetings or special information about measures that ate being taken to guatantee the quality of support). Under the same citcumstances, special attention should be given to enhancing the staff's job satisfaction since low job satisfaction in association with low team stability is likely to be correlated with low perceived service quality.

The policy of enhancing individualization of supports for persons with ID are associated with a decrease of living group size and correspondingly of DSS team size. Since size appears to be negatively associated with the amount of team membership changes and therefore with team efficacy conditions and perceived quality, this presents a paradox. Ways should be found to maintaining highly individualized support in indiviclual or very small tesidential settings (apartments and houses for 2,3 or 4 ) in combination with larger team configurations. It is suggested that the micro-unit concept of Donaldson et al. (1998) - that includes larger and interdisciplinary teams (including all relevant support professionals and facilitators) - might offer an altemative way for the organization of residential support to persons with ID. 
Bijlagen 

Bijlagen bij hoofdstuk 2 
Tabel 32.1 Onwhkeling wan de capacieit van fesidertele instelingen voor verstardelik gethandicapteri in Wederand an de. Werenigde Staten

\begin{tabular}{|c|c|c|c|c|c|c|}
\hline Jas & 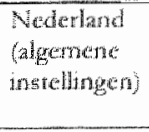 & menses & $\begin{array}{l}\text { Verengde Staten } \\
\text { (state ingerumons) }\end{array}$ & Index & 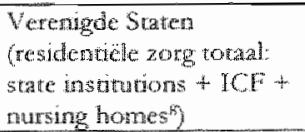 & $\begin{array}{l}\text { Inders (nual } \\
1985)\end{array}$ \\
\hline 1065 & 109341 & 100 & $194.650^{\circ}$ & 100 & & \\
\hline 1070 & 17.2751 & 158 & 173.775 & 89 & & \\
\hline 1075 & 259081 & 237 & $149.169^{\circ}$ & 7 & & \\
\hline 1980 & 290111 & 265 & 119.2290 & 61 & & \\
\hline 1945 & 30.4311 & 278 & 100.522 & 52 & 163.503 & 100 \\
\hline 1900 & 30.902 & 282 & 84818 & 44 & $176.037^{7}$ & 108 \\
\hline 1905 & 32.6982 & 299 & 64.187 & 33 & $145.442^{\prime}$ & 89 \\
\hline 2000 & 33.6943 & 308 & 47.374 & 24 & $116.527^{\circ}$ & 71 \\
\hline 2002 & $34.051^{1,5}$ & 311 & & & & \\
\hline \multicolumn{2}{|c|}{ i. Bij de Vate, $190 \%$} & \multicolumn{2}{|c|}{$5 \times$} & alige & nvomen in de samonleving & \\
\hline \multicolumn{2}{|c|}{ 2. COrG, 1997} & \multicolumn{2}{|c|}{ 6. Bunตrix, $1997 \mathrm{~b}$} & & & \\
\hline \multicolumn{2}{|c|}{ 3. 0,2002} & \multicolumn{2}{|c|}{ 7. Braddock (Fd), 2002} & & & \\
\hline \multicolumn{2}{|c|}{ 4. VW/S } & \multicolumn{3}{|c|}{ 8. insuthrionele serting , } & & \\
\hline
\end{tabular}

Trabel B2.2 Aantal rechtspersonen in de zorg woor mensen met een verstandelijke handicap per provincie en landelijk in $1999,2000,2001$ en 20020 .

\begin{tabular}{|c|c|c|c|c|}
\hline Pnowincie & 1999 & 2000 & 2001 & 2002 \\
\hline Grentingen & 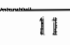 & 9 & 9 & 9 \\
\hline dutesland & 7 & 7 & 6 & 4 \\
\hline Durnthe & $\$$ & 8 & 8 & 8 \\
\hline Oworijsel & 16 & 15 & 13 & 13 \\
\hline File rolutind & 2 & 2 & 2 & 2 \\
\hline Ge dealand & 41 & 41 & 36 & 34 \\
\hline Uruedat & 21 & 22 & 19 & 17 \\
\hline Woord Folland & 27 & 25 & 27 & 25 \\
\hline zuid Holland & 30 & 29 & 29 & 27 \\
\hline Lecland & 12 & 12 & 12 & 7 \\
\hline Noord Brabant & 43 & 39 & 33 & 29 \\
\hline Jimburg & 13 & 13 & 13 & $\| 1$ \\
\hline Laradelijk & 231 & 222 & 207 & $18 \%$ \\
\hline
\end{tabular}

(1) petdentum junt 2092

Noast Aframe aussern $\| 999$ en $20012: 19.5 \%$ 
Tabel B2.3 Total aantal plaatsen in residentiële instellingen woer mensen met een versitandelijke handicap, aantal plaatsen op hoofdlocatie en percentage plaatsen gerealiseerd buiten hoofdlocaties, per provincie (1 juni 2002).

\begin{tabular}{|c|c|c|c|}
\hline Provincie & AN toralal & $\begin{array}{l}\text { ATV platsen op } \\
\text { hoofdocatie }\end{array}$ & \%o buiten hoofdlocunice \\
\hline Groningen & 999 & 849 & $15,0 \%$ \\
\hline Friesland & 1164 & 779 & $33,1 \%$ \\
\hline Drenthe & 1442 & 1000 & $30,7 \%$ \\
\hline Oretifsel & 1733 & 893 & $48,5 \%$ \\
\hline Flewoland & 328 & 99 & $69,8 \%$ \\
\hline Gelderland & 5205 & 3581 & $31,2 \%$ \\
\hline Utrechur & 3024 & 2147 & $28,00 \%$ \\
\hline Noord Holland & 3981 & 2573 & $35,4 \%$ \\
\hline Zuid Hollland & 6070 & 4142 & $31,8 \%$ \\
\hline Zeeland & 786 & 322 & $59,0 \%$ \\
\hline Noond Brabant & 5613 & 3704 & $34,0 \%$ \\
\hline Limburing & 3706 & 2120 & $42,8 \%$ \\
\hline
\end{tabular}

Gebaseerd op VWS gegevens; met dank aan dilt. E. Tjeenk Willink.

Tabel B2.4. Gemiddelde capaciteit per pand (postadres) in de Nederlandse residentiële zotgr voor mensen met een werstandelijke handicap per prowincie en landeli $\mathrm{k}$ ( 1 jumi 2002)

\begin{tabular}{|c|c|c|c|}
\hline Provincic & Asntal panden & Capaciteit & $\begin{array}{l}\text { Geniddeldx capacineit per } \\
\text { pand }\end{array}$ \\
\hline Groningen & 16 & 999 & 62 \\
\hline Friesland & 35 & 11.64 & $3 \hat{\mathbf{k}}$ \\
\hline Drenthe & 28 & 1442 & 52 \\
\hline Operijissel & 65 & 1733 & 27 \\
\hline Flexroland & 23 & 328 & 14 \\
\hline Gelderland & 123 & 5205 & 42 \\
\hline Uerecht & 84 & 3024 & 36 \\
\hline Noord Holland & 116 & 3981 & 34 \\
\hline Zuid Holland & 180 & 6070 & 34 \\
\hline Zeeland & 64 & 780 & 12 \\
\hline Nootd Brabant & 198 & 5613 & 28 \\
\hline Limburg: & 100 & 3706 & 37 \\
\hline Iandelijk & 1032 & 34051 & 33 \\
\hline
\end{tabular}

Gebaseerd op VW gege wens; met dank ann dhr. E. Thenk Willink. 
Bijlagen bij hoofdstuk 3 
Tabel B3.1. Wetenschappelike tijdschriften op het terrein van "verstandelijke beperkingen" opgenomen, in database "Kwalliteit van zorg" W. Buntinx (1976-2004)

\begin{tabular}{|c|c|c|}
\hline \multicolumn{2}{|l|}{ Tydechirift } & Uitgever \\
\hline \multicolumn{2}{|c|}{ 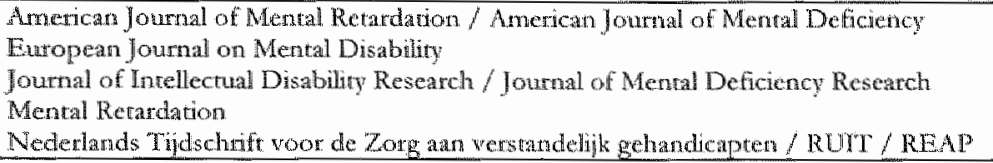 } & $\begin{array}{l}\text { AAMR } \\
\text { UNAPEI } \\
\text { IASSID } \\
\text { AAMR } \\
\text { BBI / VMn Gorcum } \\
\end{array}$ \\
\hline \multicolumn{3}{|c|}{$\begin{array}{l}\text { Tabell } 3.2 \text { Zoektermen van de literatuur search ('no limits') in PsycrNFO } \\
\text { Catiegoric_ Zoektermen }\end{array}$} \\
\hline 1 & $\begin{array}{l}\text { Mental retardation } \\
\text { Intellectual disability } \\
\text { Learning difficulty (difficultics) }\end{array}$ & \\
\hline 2 & $\begin{array}{l}\text { Sarf } \\
\text { Employee } \\
\text { Workers }\end{array}$ & \\
\hline 3 & $\begin{array}{l}\text { Turnover } \\
\text { Changes } \\
\text { Discontinuity } \\
\text { Conainuity } \\
\text { Stability } \\
\end{array}$ & \\
\hline
\end{tabular}


Minlagen

Bijlagen bij hoofdstuk 6 


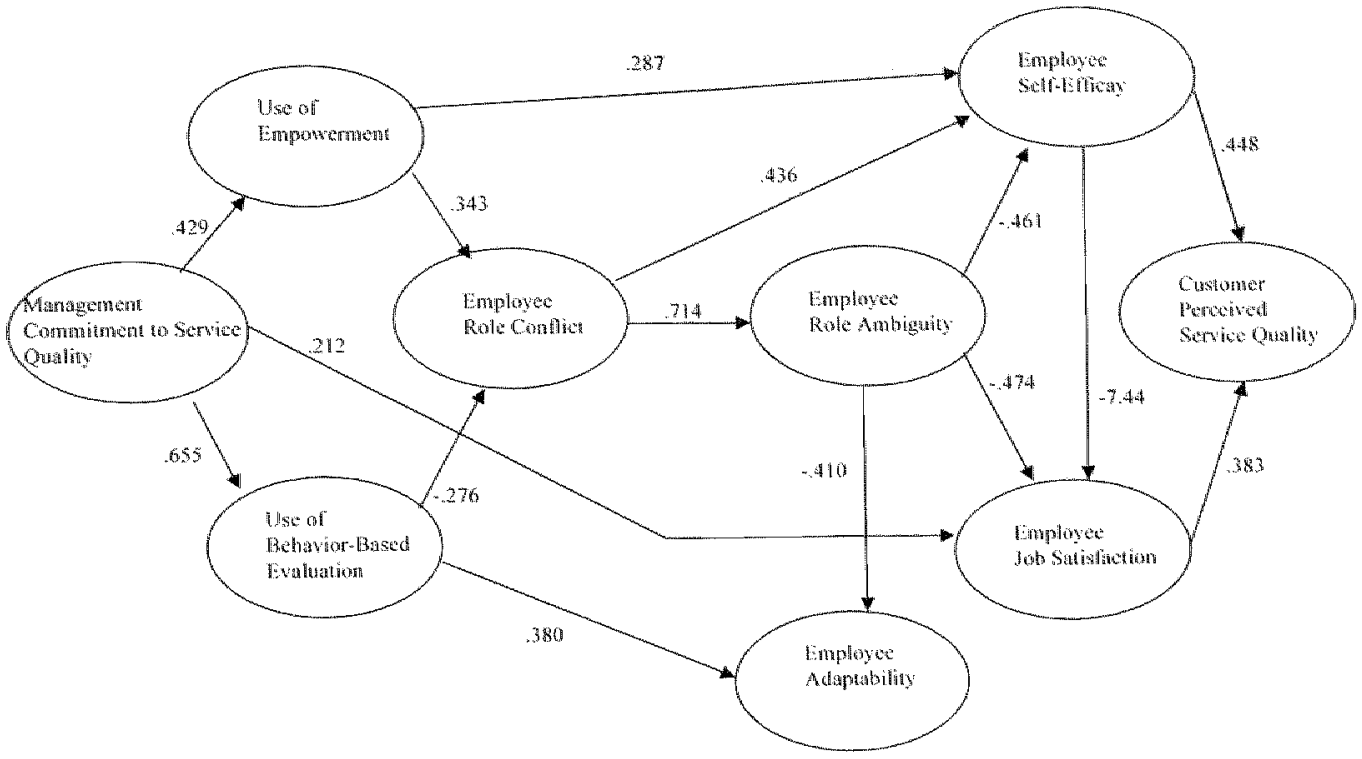

Figuur B6.1 Pad analyse van de empirische relaties tussen antecedenten van erwaren (functionele) kwalleitvan dienstwer lening (Hartline \& Ferrell, 1996, p. 66) 
Bingtiget

Bijlagen bij hoofdstuk 7 


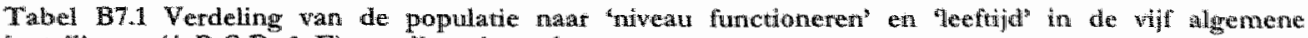
instellingen $(A, B, C, D, \&$ E) van dit onderzoek

\begin{tabular}{|c|c|c|c|c|c|c|}
\hline $\begin{array}{l}\text { Instelling A } \\
\text { Lectudid/Nw. }\end{array}$ & Licht & Mard & Emstig & Zuer wartig & Total & $\%$ \\
\hline$<20$ & 2 & 10 & 8 & 10 & 30 & 8,6 \\
\hline $20+<40$ & 0 & 33 & 36 & 27 & 96 & 27.7 \\
\hline $40<60$ & 6 & 38 & 53 & 30 & 127 & 36,6 \\
\hline $60<80$ & 14 & 39 & 24 & 5 & 82 & 23,6 \\
\hline $80+$ & 4 & 5 & 3 & 0 & 12 & 3,5 \\
\hline Totmal & 26 & 125 & 124 & 72 & 347 & \\
\hline it/ $/$ ia & 7,5 & 36,0 & 35,7 & 20,8 & & 100 \\
\hline \multicolumn{6}{|l|}{ Instelling $\mathbf{B}$} & $y$ \\
\hline$<20$ & 6 & 17 & 6 & 16 & 45 & 13,3 \\
\hline $20-<40$ & 4 & 22 & 38 & 89 & 153 & 45.1 \\
\hline $40<60$ & 3 & 27 & 36 & 48 & 114 & 3.6 \\
\hline $60-<80$ & 3 & 5 & 8 & 7 & 23 & 68 \\
\hline $80+$ & 0 & 1 & 0 & 3 & 4 & 1,2 \\
\hline Total & 16 & 72 & 88 & 163 & 339 & \\
\hline $8 / 9$ & 4,7 & 21,2 & 26,0 & 48,1 & & 100 \\
\hline \multicolumn{6}{|l|}{ Instelling $C$} & $y / 6$ \\
\hline$<20$ & 1 & 5 & 7 & 10 & 23 & 7.2 \\
\hline $20-<40$ & 8 & 27 & 34 & 24 & 93 & 20,2 \\
\hline $40-<60$ & 1. & 26 & 60 & 37 & 130 & 40,8 \\
\hline $60-<80$ & 0 & 30 & 29 & 3 & 62 & 194 \\
\hline $80+$ & 2 & 2 & 7 & 0 & 11 & 3,4 \\
\hline Totanal & 12 & 90 & 143 & 74 & 319 & \\
\hline 8 & 3,8 & 28,2 & 44,8 & 23,2 & & 100 \\
\hline $\begin{array}{l}\text { Instelling D } \\
\text { Lenftidd/Nw. }\end{array}$ & \multicolumn{5}{|c|}{ Instelling D } & $10 / 0$ \\
\hline$<20$ & 0 & 4 & 5 & 3 & 12 & 28 \\
\hline $201<40$ & 14 & 61 & 47 & 21 & 143 & 33,1 \\
\hline $40-<60$ & 20 & 137 & 54 & 14 & 225 & 52,1 \\
\hline $60 \ldots<80$ & 7 & 26 & 15 & 1 & 49 & 11,3 \\
\hline $80+$ & 1 & 2 & 0 & 0 & 3 & 0,7 \\
\hline "Totaal & 42 & 230 & 121 & 39 & 432 & \\
\hline 10 & 9,7 & 53,3 & 28,0 & 9,0 & & 100 \\
\hline $\begin{array}{l}\text { Instelling } \mathbf{E} \\
\text { Lectijal/Niv. }\end{array}$ & Licht & Matig & Errasrig & Zecr ennstig & Toranl & $8 / 6$ \\
\hline$<20$ & 10 & 6 & 0 & 3 & 19 & 5,1 \\
\hline $20<40$ & 27 & 37 & 30 & 35 & 129 & 34.3 \\
\hline $40-<60$ & 27 & 68 & 41 & 43 & 179 & 47,6 \\
\hline $60<80$ & 2 & 22 & 13 & y & 46 & 12,2 \\
\hline $80+$ & 0 & 1 & 1 & 1 & 3 & 10,8 \\
\hline Totadil & 60 & 134 & 85 & 91 & 376 & \\
\hline$a_{10}$ & 17.6 & 35,6 & 22,6 & 24,2 & & 100 \\
\hline
\end{tabular}




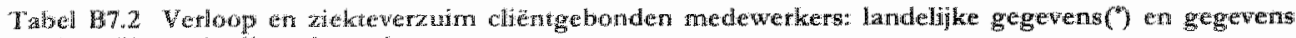

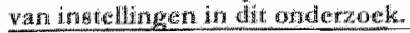

\begin{tabular}{|c|c|c|c|c|c|}
\hline Eetood & 1907 & 1998 & 1999 & 2000 & 2004 \\
\hline landelink & 12,7 & $16 ?$ & 19,6 & 21,3 & \\
\hline A & & & 150 & 14,0 & 20,9 \\
\hline $\mathbb{H}$ & & & 16,3 & 12,0 & 15,1 \\
\hline C. & & & 15.5 & 17,5 & 22,9 \\
\hline$D$ & $6 y_{i} 4$ & 80 & 8.9 & 11,5 & 11,5 \\
\hline $\mathrm{g}$ & 0,8 & 3,0 & 3,0 & 5,0 & $10 \%$ \\
\hline \multicolumn{6}{|c|}{ Ziekteverzuim } \\
\hline l.mindalik & 72 & 7,2 & 7,5 & 77 & \\
\hline A & & & 9,2 & 8,8 & 7,8 \\
\hline$B$ & & & 7,8 & 8,9 & 10,0 \\
\hline $\mathrm{C}$ & & & 9,0 & 11.5 & 12,5 \\
\hline $\mathrm{D}$ & 3,6 & 8,0 & 6,0 & 6,7 & 70 \\
\hline F & 82 & 8,9 & 7,5 & $\gamma_{0} 7$ & 6,6 \\
\hline
\end{tabular}

Kolk 2002

Tabel B7.3. Factorladingen van de items van de "Hester Adrian Research Center Family Questionnaire"

\begin{tabular}{ll}
\hline Itrem & Component 1 \\
\hline 1 & .757 \\
2 & .721 \\
3 & .697 \\
4 & .844 \\
5 & .829 \\
6 & .707 \\
7 & .670 \\
8 & .829 \\
9 & .792 \\
\hline
\end{tabular}

Extraction Method: Principal Component Anglysis.

1 component cxtracted. $N=965$. 


\section{Bijlage B7.4 Model brief aan medewerkers}

Geache $\mathbb{N}$,

In billage bij deze brief treft u een vragenlijst an met betrekking tor ecn onderzock nata de Kkwaliteit van zorg in instellingen vor mensen met een verstandeligke handicap. Het berreft een onderzoek dat wordt uitgevoerd bij de Gouverneur J. Kremersleerstoel. Dit is de bijzondere leerstoel op het terrein van verstandelijke handicap bij de Universiteit Mastricht. Het onderack wordt uitgevoerd door drs. Buntinx in samenwerking met prof. dr. A. van Gennep.

In dit onderzoek wordt in verschillende Nederlandse instellingen voor mensen met cen verstandelijke handicap, een aantal belangrijke factoren onderzocht die wan belang zijn voor de kwaliceit van de geboden zorg. De mening van medewerkers in de woning over een antal aspecten wan deze zorg is daarbij van groot belang. Aan de hand wan de uitkomsten van dit onderzock kunnen effectieve maatregelen worden voorgesteld om de kwaliteit wan de geboden zotg te verbeteren.

Aan de directie wan [instelling] werd gevraagd om medewerking te verlenen an dit onderzock. Omdat het een onderzoek betreft dat belangrijke informatic kan opleveren woor het verbeteren van de kwaliteit van zorg, én omdat het onderzoek de anonimiteit wan cliènten, medewarkers en familie volstrekt respecteert, hebben we daarmee ingestend. Met de onderzocker is overeengekomen dat de resultaten van het onderzoek nok met onze cigen instelling afzonderlijk zullen worden besproken zodat onze organisatie hiermee haar woordeel kan doen. Uw medewerking via het invulien van de bijgevoegde vagenlijst is dan ook erg belangrijk.

De toelichting bij de vragen is opgenomen op pagina 2 van de vagenlijst. Bij de vagenlijst is een antwoordenveloppe gewoegd die rechtstreeks is geadresseerd aan de. Universiteit Maastricht. U kunt de ingevulde vragenlijst hiermee zonder postzegel roezenden aan de unwersiteti. Mor het oog op de verwerking van de resultaten verzoeken wij u de ingevulde vragenlijisten zo spocdig mogelijk, en in ieder geval binnen twee weken, te retoumeren.

Met vriendelijke groeten,

[directeur instelling] 


\section{Bijlage B7.5 Model brief aan familie}

Geachere

In bijlage bij deze bricf treft u een vragentist aan met betrekking tot een onderzoek naar de kwaliteit wan zorg in instellingen voor mensen met een verstandelije handicap. Het becreft een onderzoelk dat wordt uitgevoerd bij de Gouverneur J. Kremers leerstoel. Dit is de bijzondere leerstoel op thet terrein van verstandelijke handlicap bij de Universiteit Maastricht. Her onderzoek wordt uitgevoerd door dts. W. Buntinx in samenwerking met prof. dr. A. van Gennep.

In dit onderzoek wordt in verschillende Nederlandse instellingen voor mensen met cen verstandelijke handicap cen aantal factoren onderzocht die van belang zijn voor de kwaliteit van de geboden zorg. De mening van familie, vertegenwoordigers en contactpersonen van clièten over een aantal aspecten van deze zorg is daarbij van groot belang. Aan de hand van de uitkonsten van dit onderzoek kunnen matregelen worden voorgesteld om de kwaliteir van de geboden zorg te verbeteren.

Aan de directie van [instellingl werd gevraggd om medewerking te verlenen an dit onderzoek. Ondat het een onderzock betreft dat belangrijke informatic kan opleveren woor het verbeteren van de kwaliteit wan zorg, én omdat het onderzock de anonimiteit van cliënten, medewerkers en familie strikt respecteert, hebben we daarmee ingestemd. Met de onderzoeker is overeengekomen dat de resultaten wan het onder'zoek ook met onze eigen instelling afzonderllijk zullen worden besproken zodat onze organisatie hiermee haar voordecl kan doen. Uw medewerking wordt via het invullen van de bijgevoegde vragenlijst zeet op prijs gesteld.

De toelichting bij de vagen is opgenomen op pagina 2 van de vragenlijst. Bij de vragenlijst is een antwoord enveloppe gevoegd die rechtstreeks is geadressectd aan de Universiteit Maastricht. U kunt de ingevulde vragenlijst hiermee zonder postzegel toezenden aan de universiteit.

Met het oog op de verwerking van de resultaten verzoeken wij u de ingevulde vragenlijsten $z o$ snel mogelijk in te vullen en binnen twee weken te retourneren.

Met vtiendelijke groeten,

|direcreur instelling| 


\section{Bijlage B7.6 Model rappelbrief medewerkers}

\section{Geachte medewerker,}

Enige tijd geleden ontving u een vragenlijst met betrekking tot een onderzock natat de kwalteit van zorg in instellingen voor mensen met een verstandelijke handicap (Unversiteir Maastricht).

Er zịn al veel vragenlijsten retour ontwangen. Als u de enquêtte reeds heeft geretoumeerd, danken wiij u hierbil hartelijk voor uw medewerking. Mocht u nog niet in de gelegenheid zijn geweest het vagen formulier in te vulten, dan verzocken wij u dit alsnog te doen en deze zo spoedig mogelijk in te sturen. Uw bijdrage aan het onderzoek kan dan nog meegenomen worden. Mocht uw vagenlijst of enveloppe zoek zijn gerakt, dan kunt u telefonisch een nieuwe opvagen bij $N$. Zij is op maandag, dinsdag en donderdag bereikbaar op telefoonnummer [tel....].

Uit enkele reacties van medewerkers die hun vagenlijst al instuurden bijkt dat sommige mensen vragen hebben over de cijfercode onderaan de vragenlijst. Dit cijfer verwijst naat instelling en woongroep. Uit deze code kan absoluue niet worden afgeleid wie de invuller van her formulier is. De invullers van de vragen blijven volstrekt anoniem. Bij de verwerking wordt de code gebruikt om de resultaten te kunnen bekijken op woongroepniveau.

Nogmaals onze dank voor uw medewerking.

Met wriendelijke groeten,

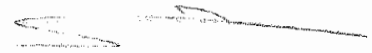

drs. W.H.E. Buntinx

Manager onderzoek en ontwikkeling 


\section{Bijlage B7.7 Model rappelbrief familie}

\section{Geache $\mathbb{N}$,}

Enige tijd geleden ontving u een vragenlijst met betrekking tot een onderzock naar de kwaliteit wan zorg in instellingen woot mensen met een verstandelike handicap (Universiteit Maastricht).

Er zijn al weel wragenlijsten retour ontwangen. Als u de enquête reeds heefi geretoumeerd, danken wij u hierbij hartijk voor uw medewerking. Mocht u nog niet in de gelegenheid zijn geweest het vragenformulier in te vullen, dan verzoelken wij u dit alsnog te doen en deze zo spoedig mogelijk. in te sturen. Uw bijdrage aan het onderzoek kan dan nog meegenomen worden. Mocht ww wragenlijst of enveloppe zoek zijn gerakt, dan kunt u telefonisch een nieuwe opvagen bij $\mathrm{N}$. Zij is op maandag, dinsdag en donderdag bereikbaar op telefoonnummer [ $[\mathrm{el} . . .$.$] .$

Uit cnkele teacties blikt dat sommige mensen vagen hebben over de cijfercode achterop de vragenlijst. Dit cijfer verwijse naar instelling en woongroep. Uit deze code kan absoluut nict worden afgeleid wie de invuller van het formulier is. De invullers wan de vragen blijven volstrekt anoniem. Bij de verwerking wordt de code gebruikt on de resultaten te kunnen bekijken op woongroepniveat.

Nogmals onze dank voor uw medewerking.

Met vriendelijke groeten,

drs. W.H.E. Buntinx

Manager onderzoek en ontwrikkeling 
Bijlage B7.8

\section{Vragenlijst}

\section{medewerkers}

Kwaliteit van zorg in residentiële instellingen voor mensen met een verstandelijke handicap 
Biplugen

Mastrichise Arberdssatisfactie Schaal: J. Landeweerd, N. Boumans, J. Nissen (1996) Role Ambiguiny: Hartine M.D. and Ferrell O.C. (1996)

Vertrouwen in team: Alper S. (1998)

Intiatief: Hartline M.D. and Ferrell O.C. (1996) 


\section{Toelichting bij de vragenlijst}

Woor u ligt een vragenlijst met betrekking tot de wijze watrop groepsleiders in de woonzorg voor mensen met een verstandelijke handicap hun werk erwaren.

In deze vragenlijst wordt naar uw eigen mening en nar uw eigen ervaringen gevraagd. Er zijn dus geen goede of slechte antwoorden.

Van belang is dat u met uw antwoord zo goed mogelijk uw eigen mening weergeeft over het desbetreffende aspect. Het is belangrijk om te weten dat alle informatie volstrekt anoniem wordt verwerkt.

Het doel van deze vragenlijst is om informatie te verzamelen die kan helpen om beter inzicht to krijgen in enkele belangrijke aspecten van kwaliteit van zorg in Nederlandse instellingen voot mensen met een verstandelijke handicap. Met name gat het bij deze vtagenlijst over ervaringen wan medewerkers in de woonsituatie (woongroep, leefgroep, woning...) van mensen met ean verstandelijke handicap Dit inzicht kan bijdragen tot verbetering van de zorg in het algemeen.

De vragenlijst bestaat uit vier delen. Bij elk deel stat een korte toelichting yoor het beantwoorden. Meestal betreft het vragen die u eenvoudig kunt beantwoorden door het aanknisen van cen hokje.

\section{YOORBEEL:}

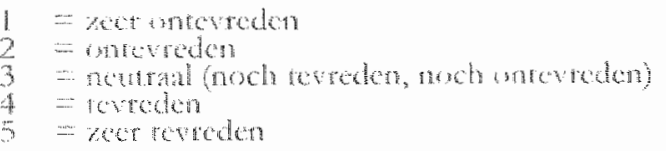

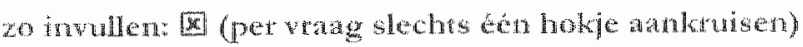

Hoe teveden bewt une:

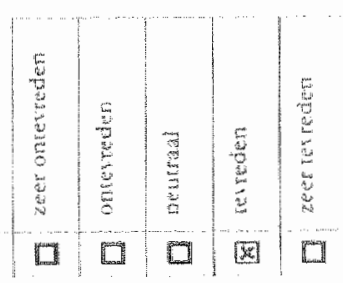

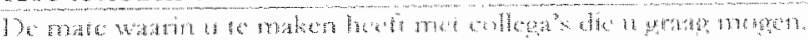

Ten slotte: de antwoorden op deze vragenlijst worden automatisch verwerkt. Dat betckent dat slechts éen antwoord per vtaag kan worden gegeven. Indien meetdere antwoorden wonden gegewen telt die vraag niet mee.

Indien u zich heeft vergist met het plattsen van een kruisje in een hokje, kunt u dit antwootel duidelijk doorstrepen en vetwolgens het juiste hokje anankruisen. U doet dit dan zo:

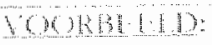

min

Cartectic

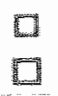

ind

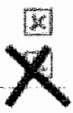


pintagen

\section{Vragen vooraf:}

Deze vragen hebben betrekking op de invulter van deze vragenlijst.

1. Uw functie

Omcirkel uw antwoord

1 Hoofd (afdelingshoofd)

2 Groepshoofd (groepsoudste)

3 Groepsbegeleider

4. Medewerker groepsbegeleiding

5 Huishoudelijk medewerker (civiel assistent)

6 Anders (omschriig):

2. Bent u 'persoonlijk begeleider' van één of meerdere cliënten wan uw instelling?

Oncirkel uw antwoord

Ja $/ \operatorname{Nan}$

3. Uw geslacht:

Omcirkel uw antwoord

Man / Vrouw

4. Uw leeftijd

Vul in: ...... jat

5. Hoe lang werkt $u$ in uw huidige woongroep?

Aantal maanden:

6. Hoe lang werkt $\mathrm{u}$ bij uw huidige werkgever?

Aantal maanden: 


\section{Deel 1}

De wolgende vragen hebben betrekking op bepaalde aspecten wan uw eigen werksituatie. Wilt u per waag angeven hoe tevreden u bent met het desbeteffende aspect?

1 zeer ontevreden

$\frac{2}{3}=$ ontevreden

3 = neutraal (noch tevteden, noch ontevtreden)

4 = nevreden

5 zeer tevreden

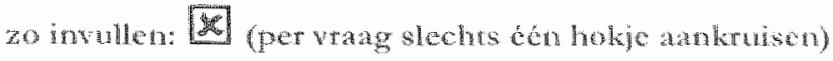

\section{Hoe tevreden bent $u$ met:}

1 De mate warin u van tevoren weet wat voor werk u opgedragen krijgt.

2 De mate warin u over het algemeen tijd hebt on uw diënten goed te verzorgen.

3 De mate warin u als groepsleider goede promotiemogelijkbeden the bt in deze zorgorganisatue.

4 De mate waarin het werk u her gevoel geeft dat u werkelijk tets kunt.

5 De mate waarin a unw collega's graag mag.

6 De mate waarin u individuele zorg an uw clienten kunt geven.

7 De mate watin u mogelijkheden hebt om wooruit te komen in deze zorgotganisatie.

8 De mate waarin in uw cliènten graag mag.

9 De mate waarin u uw kundigheden en mogelijkheden kunt gebruiken.

10 De mate warin $u$ in uw werk kunt laten merken dat u uw collega's sympathiek windt.

11 De mate warin de leidinggevende op de hoogte is van de gang wan zaken in de woongroep.

12. De mate waarin er vaste en duidelijk omschreven regels zijn waaraan u zich kunt houden.

13. De mate warin a het gevoel hebe dat de leiding van de woongroep good verloopt.

14 De mate warin er cen rechtvaardig promotebeleid in dese organisatic wordt gevoerd.

15 De nate warin het werk het beste uit uhath watroe $\mathrm{u}$ in stat bent.

16 De mate warin u verteld wordt wat er van u verwache wordt

17 De mate watin a het gevoel hebt dat clienten us een geschikte "meid" of "kerel" vinden

18 De mate warin u te maken hebt met collegra's die u graag moger.

19 De nate waarin de leidinggevende zjin wak goed werstat.

20 De mate waarin a het gevoel hobe psycho-sociale begeleiding an uw dienten te geven.

21 De mate waarin u te maken hebt met cliênten die u gragg mogen.

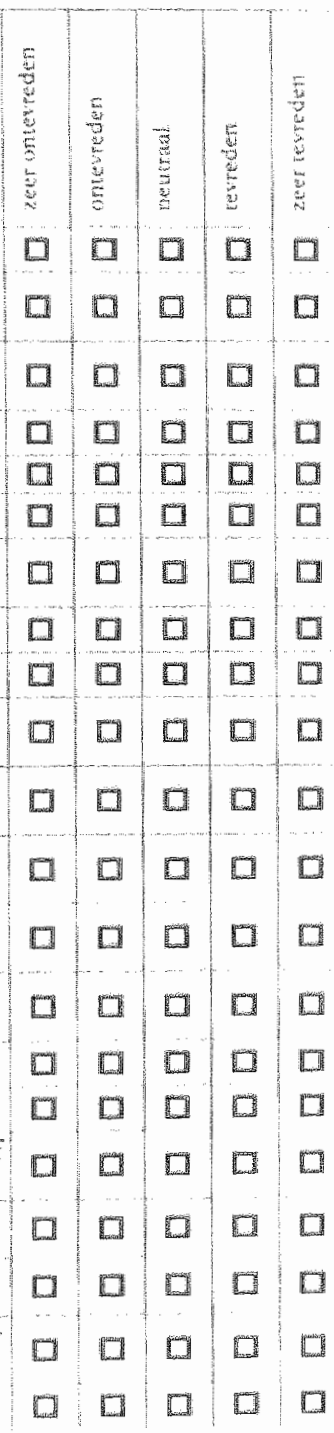




\section{Deel 2}

De volgende vragen hebben betrekking op uw wijze van werken. Will u per vraag angeven hot zeer u het ecens of oneens bent met het desbetreffende aspece?

Uheeft telkens de keuze uit de wolgende alternatieven:

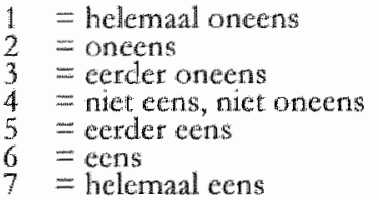

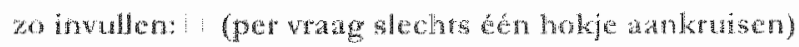

Hoe eens bent u het met:

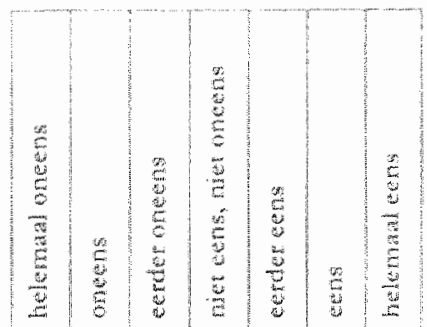

1 Th ben er zeker van dat mijn wijze van werken de beste maner onze bewoners te ondersteunen

2 Ik weet goed hoe ik mijn tijd moet verdelen over de verschillende aspecten wan mijn werk

3. Ik weet prima hoe ilk moct omgilan met Lachten van ouders of verwanten

Ik weet hoe

Ik weet hoe ak mijn dagelijks werk moet plannen en organise ren

6 Th weet hoe ik met ongewone siruaties moet omgan

7 Ik weet wave ik hulp kan krigen wanneer $\mathrm{k}$ ondersteuning bij min werk nodig heb

8 Ik weet hoe ik soepel met regels moct omgatan zodat de clienten twreden zign over de zorg

9 Hk weet precies wat ik zelf kan beslissen zonder toestemming te hoeven vagen san mijn leidinggevende

10 Ik ken de regels en voorschrifren van mijn organisatie

11 Ik wet polgens welke matstaven mijn leidinggewende mijn werk beoordeelt

12 Ik weet hoe reveden mijn leidinggevende is over mijn werk

13 Ik weet precigs voor welke onderdelen wan mijn werk ik meer stholing zou willen

14 Ik weet welke zaken van belang zijn om in deze organisacie roornit te komen en promotic te maken

15 Ik weet precies hoe mijn leidingzerende verwache dat ik mijn tijd indect

16 Ik heb een goed beeld van de tevredenheid wan mijn clienten met mijon week

17 Ik weet wat de clienten van mij werwachten biy het uitoefenen wh mijn functic 


\section{Deel 3}

De volgende vragen hebben betrekking op het team. Wilt u per vraag aangeven hoe zeer a het eens of oneens bent met het desbetreffende aspect?

Uheeft telkens de keuze uit de volgende alternatieven:

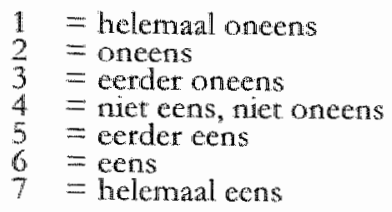

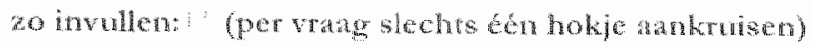

\section{Hoe eens bent o het met:}

1 Het contact met de collega's in ons team inspirert mij tot her leveren van betere prestatices in mijn werk

2 Het contact met onze teamleden vermindert ming zin om hat te wretken

3 Het contace met de collega's in het team maakt dat ik mijn functie wil blipven uitoefenen

4 Het contact met de collega's in mijn team doet me ernstig overwegen om overplaarsing aan te vragen

5 Ik heb een groot vertrouwen in de functievatudigheden van min collega's in her rearm

6 Ik heb een groot vertrouwen in de motieven en de platunen van mijn collega's in het team

7 It heb een sterke mate van vertrouwen in de sociale vardigheden wan de collegal"s in ons team 


\section{Deel 4}

De volgende wrigen hebben betrekking op het nemen van initatief in het team. Wilt u per vrag angeven hoe zeer u het eens of oneens bent met het desbetreffende aspect?

U heeft telkens de keuze uit de volgende alternatieven:

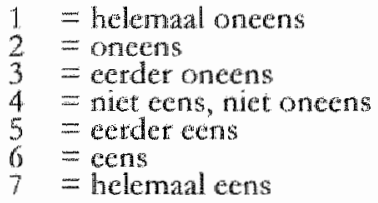

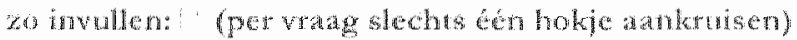

\section{Hoe eens bent u het met:}

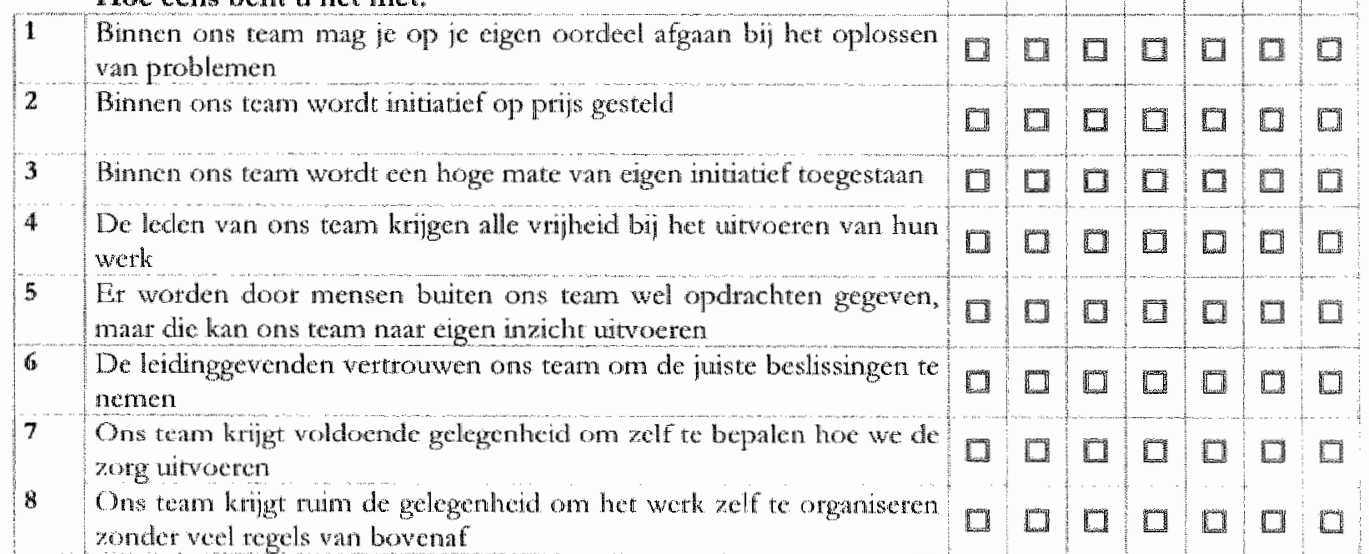

Wij danken u hartelijk voor uw medewerking.

Wilt u nog opmerkingen kwijt nat. aanleiding van het invullen van deze vagenlijst, dan kunt u deze hier noteren:

U kunt nu de volledige yeagenlijst dubbelgevouwen in de bijgestoten enveloppe per post inzenden. Een postzegel is niet nodig. 
Bijlage B7.9

\section{Vragenlijst}

\section{Kwaliteit van zorg}

vanuit het perspectief wan familie van bewoners wan residentiele instellingen voor mensen met een verstandelijke handicap 
Biflagen

Fomily Questionnate: Hester Adrian Research Centre (Manchester) Customer"s Percerved Service Quality: Hartine \& Ferrell (1996) 


\section{Toelichting bij de vragenlijst}

Voor u ligt een vragenlijst met betrekking tot de kwaliteit van de zorg in de woonsiruarie wan mensen met een verstandelike handicap in Nederlandse instellingen. Onder "woonsiturtie" verstatan we de 'woongroep' of 'leefgroep' of de woning wat uw tamilielid met een antal medebewoners woont. Als we in deze vagenlijst spreken wan 'begeleiders" bedoclen we de "groepsleiders", "zorgkundigen", "groepsbegeleiders" maar altijd medewerkers van de instelling dic dagelijkse zorg bieden binnen de woonsituatie van uw Eamilielid.

In deze vragenlijst wordt nat uw eigen mening en uw eigen ervaringen gevraagd. Er zijo dus geen goede of slechte antwoorden. Het is belangrijk om te weten dat alle informatie anoniem word verwerkt.

Het doel ervan is om informatie te verzamelen die kan helpen om beter zicht te kriggen op enkele belangrijke aspecten wan kwaliteit van zorg in Nederlandse instellingen voor mensen met een. verstandelijke handicap. Dit inzicht kan bijdragen tot verbetering van de zorg in het algemeen.

De vragenlijst bestaat uit vier onderdelen. Bij elk onderdeel staat een kotte toelichting voot het beantwoorden. Meestal betreft het vragen die u kunt beantwoorden door het aankruisen van een hokje. Bij elk onderdeel staat een woorbeld hoe u dit kunt doen. Bij het laatste onderdeel kunt u bij enkele vragen in uw eigen wootden een antwoord geven.

De vragenlijst is bedoeld voor de persoon die ervaring heeft met de woonsituatic van uw familiclid en de medewerkers in die woonsituatie.

Het kan voorkomen dat u sommige vragen moeilijk te beantwoorden vindt omdat uw familiclid (zeer) ernstige beperkingen heeft en claardoor de vaag minder van toepassing lijkt. U wordt gevraagd in die situaties toch zo veel mogelijk het antwoord te geven dat met uw mening of ervaring overeenkomt.

Tien slotte: de antwoorden op deze vagenlijst worden automatisch verwerkt. Dat betekent dat slechts één antwoord per vraag kan worden gegeven. Indien meerdere antwoorden worden gegeven telt die vrang niet mee. Indien $u$ zich heeft vergist met het platsen van een kruisje in een hokje, kunt u dit antwoord duidelijk doorstrepen en vervolgens het juiste bokjo aankruisen. U doet dit dan zo:

\section{Visteid}

Four?

Horecitan?

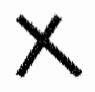


Bingen

\section{Deel 1}

Enkele wagen over de invuller van deze vragenligse

1. Wat is uw relatie met de bewoner?

Omcirkel het cijet van her antwoord dat wan toepassing is.

Bent w:

1. oudew wan de bewonet

2. broet of zus van de bewoner

3. wel familie mangeen ouder, broer of zus

4. geen familic, maar wel een relatie als kennis of contactpersoon

$2 \quad$ Wat is uw geslacht?

Omcirkel uw antwoord.

$\operatorname{man} /$ vrouw

3. Wat is uw leeftijd?

jaar 


\section{Deel 2}

Dit deel bestaat wit een serie vragen over:

A. aspecten van de zorg in de woonsituatie van uw familielid dic u belangrijk vindt, en en tweede serie vragen over:

B. uw ervaringen met de zorg in de woonsituatie van uw tamilielid

\section{A. Wel of niet belangrijk?}

Familieleden van werschillende bewoners vinden niet aldjd dezelfde dingen even belangrijk. Daatom wordt eerst aan u gewraagd hoe belangrijk u een bepaald aspect van de zorg in de woonsituatie vindt. Her gat telkens over de woonsituatie warun uw eigen fanilielid verblijt. Hieronder staan elf zinnen die telkens beginnen mot "Hoe belangrijk vindr u dat..." en vervolgens een aspect van de zorg noemen. Wij vragen u onder iedere zin aan te kruisen hoe belangrijk u datgene vind dat hierin wordt genoemd.

\section{VOORBEELD:}

Howe belangrible vind a hed dat ...

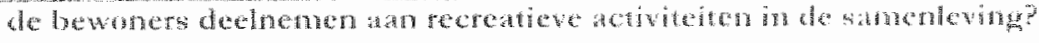

\begin{tabular}{|c|c|c|c|}
\hline Wo hotungah & 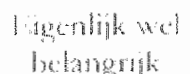 & Hed & 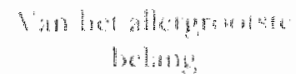 \\
\hline
\end{tabular}




\section{VRAGEN:}

\section{Hoe belangrijk vind $u$ het dat...}

1. de instelling geschikte, regelmatige en voldoende dagactiviteiten aanbiedt woor de bewoners (bijvorbeld: werk, angepaste bezigheden, on wikkelingsactiviteiten)?

\begin{tabular}{|c|c|c|c|}
\hline Niet belangrik & $\begin{array}{l}\text { Eigenlijk wo } \\
\text { belangrijk }\end{array}$ & Belangrij & Wan het allergrootste \\
\hline
\end{tabular}

2. de instelling de bewoners onderstewnt bij het onderhouden, verder ontwikkelen of opnieuw opbouwen van contacten met hun gezinsleden en serwarten?
Niet belangrijk
Eigenlijk wel
belangrij $k$
Belangrijk
Van het allergrootste belang

3. de instelling de bewoners bescheming biedt tegen uitbuiting of misbruik doot medewerkers, doot andere bewoners of door mensen uit de samenleving?
Niet belangrijk
Eigenlifk wel
Belangrijk
Van her allergrootste belangrijk belang

4. de bewoners voldoende ondersteuning en hulp krigen om aan dagelijkse activiteiten deel te nemen en plezierig bezig te zipn?
Niet belangripk
Eigenlijk wel
belangrijk
Belangrijk
Van het allergrootste belang

5 de bewoners een actieve en gezonde levenswijze hebben?
Niet belangritk
Eigenlijk wel
Belangrijk
Van bet alletgrootste belangrijk belang:

6. de bewoners er goed gekleed en gezond witzien?

Nier belangrijk Eigenlijk wel
belangrijk Belangrijk Van het allergrootste belang 
7. de bewoners zelf zoveel als mogelijk kunnen kiezen met betrekkng tor dagelijke dingen zoals biprootbeeld welke kleren ze aandoen, wat ze willen eten en wat ze mer hur geld willen doen?

Nier belangrijk

$$
\begin{gathered}
\text { Eigenlijk wel } \\
\text { belangrijk }
\end{gathered}
$$

Belangrijk

Van het allergrootse beling

8. de bewonets emotionele ondersteuning krigen en allijd iemand hebben om op terug te vallen als ze ergens boos of verdrietig om zijn?

Ner belangrijk

$$
\begin{gathered}
\text { Eigenlijk wel } \\
\text { belangrijk }
\end{gathered}
$$

Van het allergrootste belang

9. de bewoners gelukkig en tevreden zijo?
Niet belangrijk
Eigenlijk wel
belangrijk
Belangtijk
Van het allergrooste belang

10.

u zich betrokken voelt bij beslissingen met betrekking tot uw familiclid in zijn of haar woonsinatie?
Niet belangrijk
Eigenlijk wel belangrijk
Belangrijk
Van thet allergrootste belang

11.

u goed wordt geinformeerd over het wel en wee van uw familielid?

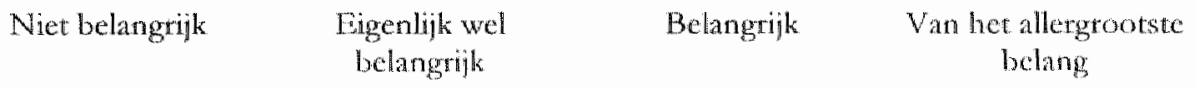


B. Uw ervaringen

U wordt nu gevaragd om an te geven wat uw eigen ervaringen zijn met deze elf aspecten wan zorg in de wonnsituatife van uw familielid. Deze aspecten staan nu in elf zinnen verwoord. Elke xin is geformuleerd als een bewering ower de zorg in de woonsicuatie van uw familielid. Wilt u heronder angewen hoc goed dexe bewering overenkomt met ww eigen ervaringen.

U kunt uw antwootd geven op ecri zewen puntsschaal.

U zet een kruisje in het meest linkse vakje als u craring op dit gebied zeer slecht is en whet met de\%e bewering helemaal oneens bent. U zet een kruisje in het meest rechtse vakje als uw ervaring zeer positief is en u het dus met de bewering hetemaal eens bent. Daartussen heeft a de mogeljikheid om aan te geven of uw ervaringen eerder positief of eerder negatief aijn en dus of u het meet of minder eens bent met de bewering. Als uw ervaring met dit aspect nict positief en niet negatief is of $u$ geen mening heeft, zet u een krusje in het middelste vakje.

U mag slechts ến vakje atankruisen.

VOORELED:

\section{De bewoners hebben regelmatig recreatieve activiteiten in de samenleving?}

\begin{tabular}{|c|c|c|c|c|c|}
\hline 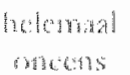 & ancens & 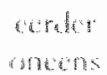 & 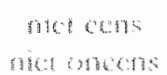 & moner ons & $\cos t s$ \\
\hline
\end{tabular}




\section{VRAGEN:}

Hoe eens bent u het met de volgende witspraken?

1. De instelling biedt geschikte, regelmatige en voldoende dagactiviteiten wan voor de bewoners (bijwoorbeeld: werk, aangepaste bezigheden, ontwikkelingsactiviteiten).

helemanl oneens eerder nietens ecrder eens eens helcmal oneens oneens niet oncens cens

2. De instelling ondersteunt de bewoners bij het onderhouden, verder ontwikkelen of opnieuw opbouwen van contacten met hun gezinsleden en verwanten.

thelemal oneens cerder nict cens cerder eens cens hetemaal
oneens

3. De instelling biedt de bewoners bescherming tegen uitbuiting of misbruik door medewerkers, door andere bewoners of door mensen uit de samenleving.

helemal oneens eerder niet eens exder eens cens
oncens

4. De bewoners krijgen voldoende ondersteuning en hulp om aan dagelijkse activiteiten deel te nemen en plezierig bezig te zijn.

helemal oneens cerder niet cens eerder eens cens helemal
oneens

5. De bewoners hebben een actieve en gezonde levenswijze.

helemal oneens ecrder nieteens cerdereens cens holumal
oneens

6. De bewoners zien er goed gekleed en gezond wit.

helemal oneens corder nictoons cordercons eens helemal
oncens


7. De bewoners kunnen zoveel als mogelijk zelf kiezen met betrekking tot dagelijkse dingen zoals bijwoorbeeld welke keren ze aandoen, wat ze willen eten en wat ze met hun geld willen doen.

helemal oncens eerder niet eens eerder eens eens helemal
oncens

8. De bewoners krijgen volop emotionele ondersteuning en hebben altijd iemand om op terug te wallen als ze ergens boos of verdtietig om zijn.

hclemal oneens eetder nieteens eerdereens eens helemal
oneens

9. De bewoners liiken gelukkig en tevreden.

helemal oneens eerder niet eens eerder eens eens helemaal
oneens

10. U voelt zich betrokken bij beslissingen met betrekking tot uw familielid in zijn of haar woonsituatie.

helemal oncens cerder mieteens eerder eens eens helemant
oneens

11. U wordt goed geïnformeerd over het wel en wee van uw familielid.

helemal oneens cerder nieteens eerdereens eens helemall
oncens




\section{Dieel 3}

Het volgen tien vragen die betrekking hebben op uw ervaringen met de begeleiders wan uw familielid in zijn of haar woonsituatie.

Natuurligk kunt u verschillende ervaringen hebben met verschillende begeleiders. Wia vragen u echter een algemeen oordeel te geven op basis van uw cigen enaringen met de gropsleiders van de woongroep van uw familielid.

De wijze van antwoorden is hetzelfde zoals bij het worige onderdeel: u geeft ann door middel van het plaatsen van een kruisje in welke mate u het eens of oneens bent met de uitspraken.

U mag slechts één vakje aankruisen.

In hoeverte bent w het eens of oneens met de volgende witspraken?

1. Wanneer ik de woning bezoek besteden de groepsleiders meteen aandacht aan mij.

helemal oneens eerder niet eens eerder cens eens helemal
oneens $\quad \begin{gathered}\text { oneens niet oneens } \\ \text { cens }\end{gathered}$

2. De groepsleiders reageren op een vraag of verzoek van mij, ook al hebben ze het druk.

helemal oneens eerder niet eens eerder eens eens helemanl
oneens

3. Ik merk dat de groepsleiders vertrouwen in mij hebben.

helemal oneens eerder nieteens eetdercens eens helemal
oncens

4. De groepsleiders zijn vriendelijk.

helemal oncens eerder nieteens eerdereens cens helemal
oneens

5. Wanneer ik iets met groepsleiders bespreek merk ik dat ze vertrouwen in mij hebben.

helemal oneens cerder nieteens cerder eens cens helemal
oneens


6. De groepsleiders zipri goed in statat om mij te woord te staan.

helemal oneens cerder niet eens eerdereens cens helemal
oneens

7. De instelling geeft voldoende aandacht aan individuele familieleden van de bewoners.

$\begin{gathered}\text { helemal oneens cerder nier eens cerder eens eens helemal } \\ \text { oneens }\end{gathered}$
oneens niet oneens

8. Ik ontvang voldoende aandacht van de groepsleiders.

helemal oneens cerder niet eens eerder eens eens helemaal
oneens

9. Ik merk dat de groepsleiders hart woor de zorg van mijn familielid hebben.

helemal oneens eerder nieteens eerder eens eens
oneens $\quad \begin{gathered}\text { helemal } \\ \text { oneens nict oneens }\end{gathered}$

10. De groepsleiders zijn goed in staat om te begrijpen wat mij bezighoudt met betrekking tot de zorg voor mijn familielid.

helemal oneens $\begin{gathered}\text { eerder niet eens eerder eens eens helemal } \\ \text { oncens }\end{gathered}$
oneens niet oneens




\section{Deel 4}

In dit latste deel wordt uw mening gevraagd ower vier aspecten van de zorg woor uw familielid. In de eerste twee vagen kunt u een ciffer geven door dit te omcirkelen.

In de twee laatste vagen kunt u antwoorden in uw eigen woorden.

\section{Hoe gelukkig is volgens $u$, uw familielid?}

Omcirkel uw antwoord:

7: zeer gelukkig

6: gelukkig

5: eerder gelukkig

4: niet gelukkig / niet ongelukkig

3: eerder ongelukkig

2. ongelukkig

1: zeer ongelukkig

2 Hoe tevreden bent $u$ in het algemeen over de zorg die door de zorgorganisatic van uw familielid wordt geboden?

Omcirkel uw antwoord:

7: zeer tevreden

6: tevreden

5: cender teveden

4: niet tevreden / niet onterteden

3: cerder ontevreden

2: ontevreden

1: zeer ontevreden 
3 Welke drie dingen wardeert $\mathrm{u}$ het meest bij de instelling waar uw familielid woont. Geef dit an in uw eigen woorden:

4 Welke drie dingen zon u het liefst verbeterd willen zien? Geef dit aan in uw eigen woorden:

Wilt u nog opmerkingen kwijt naar aanleiding van het invullen van deze vragenlijst, dan kunt u deze hier noteren:

Hartelijk bedankt voor het inwallen wan deze vagenlijst

U kunt nu de volledige vragenlijst dubbelgevouwen in de bijgeslaten enveloppe terugsturen. Een postzegel is niet nodig. 
Bijlagen bij hoofdstuk 8 


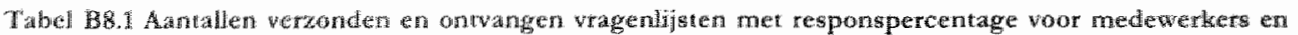
familte per instelling

\begin{tabular}{|c|c|c|c|}
\hline & 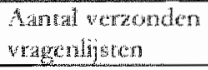 & $\begin{array}{l}\text { Aamial ontrangen } \\
\text { yragenlifster: }\end{array}$ & Fueponsperentage \\
\hline \multicolumn{4}{|l|}{ Medrwerbera } \\
\hline Instelling & 367 & 273 & 74,39 \\
\hline Instelling & 321 & 214 & 66,67 \\
\hline Instelling $\mathrm{C}$ & 340 & 218 & 64,12 \\
\hline Ineteling $D$ & 346 & 243 & 70,23 \\
\hline \multirow[t]{2}{*}{ Inetelling E } & 394 & 194 & 49,24 \\
\hline & 1768 & $1151^{\%}$ & $65,10 \%$ \\
\hline \multicolumn{4}{|l|}{ Fanmilie } \\
\hline Instelling $A$ & 336 & 204 & 60,71 \\
\hline Instelling 13 & 334 & 170 & 50,90 \\
\hline Instelling $C$ & 315 & 167 & 53,02 \\
\hline Instelling D & 415 & 316 & 76,14 \\
\hline \multirow[t]{2}{*}{ Irsiteling $\mathrm{E}$} & 303 & 159 & 52,48 \\
\hline & 1703 & $1021 \%$ & 6000 \\
\hline
\end{tabular}

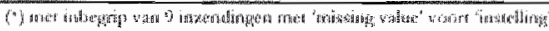

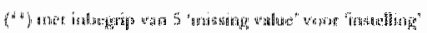

"Tabe1 138,2 Procentuele vetdeling van functies van de respondenten medewerkers, per instelling(1)

\begin{tabular}{|c|c|c|c|}
\hline \multicolumn{2}{|l|}{ Jnstrallingen $A, \bar{B}, \overline{C D}$} & \multicolumn{2}{|l|}{ Instelling $E$} \\
\hline Functies & $\%$ & Functios & $y_{0}$ \\
\hline Afdrlingshoofd & 0,5 & Zorgmedewerker & 60,3 \\
\hline Grocpsinoofd & 8,6 & Persoonlije assistent & 7.8 \\
\hline Guopstuegelcider & 44,0 & Ondetstemend zorgmedewerker & 6,7 \\
\hline Medewerker gropepsegeleiding & 36,4 & Gastrroun/-heer & $\left\|\gamma_{n}\right\|$ \\
\hline Husshoudelik medewerker & 3,8 & Werkend medewerker & 1,6 \\
\hline Anders & 6,7 & Anders & 0,5 \\
\hline Total & 100,0 & Total & 100,0 \\
\hline
\end{tabular}

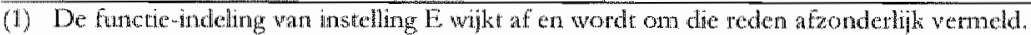

T'thel B8.3 Relatic to bewoner bij de tespondenten / familie per instelling en natar relatie tot do bewonter (petcentages)

\begin{tabular}{|c|c|c|c|c|}
\hline lnsiclling & oulat ers & broen of $x$ us & Gamilic & gecen frmilita \\
\hline$A$ & 328 & 56,3 & 5,2 & 5.7 \\
\hline$\nabla \$$ & 540 & 32,3 & 6,8 & 6,8 \\
\hline C & 35,4 & 53.4 & 7,5 & 37 \\
\hline 10 & 46,9 & 48,5 & 3,0 & 1,6 \\
\hline$\because$ & 560 & 30.7 & 67 & 67 \\
\hline lomal & 4,8 & 45,4 & 5,4 & 4.4 \\
\hline
\end{tabular}

(1) Vort de gehancerde omschrijving, zie bijlage B7.9 (wagenligst bamilie) 
Tabel B8.4 Rangcorrelaties (Spearman's g) tussen personeelswiselingmaten STAB, MNF en TOWO wn verloop respectievelijk ziekteverzuim in de vije instellingen wan dit onderzoek

\begin{tabular}{|c|c|c|c|c|c|}
\hline & $S T A B$ & NMPR & Towis & VERL & $212 \mathrm{Km}$ \\
\hline$\$ T A B$ & 1.00 & 30 & & & \\
\hline TWR & .30 & 1.00 & & & \\
\hline $\operatorname{Tona}$ & -.30 & .70 & 1.00 & & \\
\hline VERLOOP & -90 & -.10 & .40 & $\$ .00$ & \\
\hline ZIEKTE & -70 & -.20 & .30 & $.90^{*}$ & 1.00 \\
\hline
\end{tabular}

* significant op her $\mathrm{p}=05$ niveau (wwezind (dig)

Now verloop en ziekteqerzum gebaseerd op tabel B7.2 (fan 200y)

Tabel B8.5 Intercorrelaties tussen $\mathrm{STAB}$, INFR, TOWG en de woongroepkenmerken NBEW, $2 O \mathrm{OW}$, SOC, CLUS, de effectiviteitaspecten wan teamfunctioneren MAS, ROL, VER, AUT, en de door fanilie ervaren kwaliteit van begeleiding HARQ EN CPSQ $(\mathrm{N}=180)$

\begin{tabular}{|c|c|c|c|c|c|c|c|c|c|c|c|c|c|}
\hline & STEB & LNIR & TOMNe: & CLUS & 806 & N1DIX & 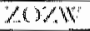 & M1S & $R()$ & Mla & ALI" & HARC & 61050 \\
\hline $5 \mathrm{MB}$ & 1 & & & & & & & & & & & & \\
\hline MSIR & $-33^{2}$ & 1 & & & & & & & & & & & \\
\hline Th & $.19^{\mathrm{k}}$ & .96 & 1 & & & & & & & & & & \\
\hline Clutgin & . $16^{-5}$ & $-3 g \times x$ & 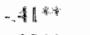 & 1 & & & & & & & & & \\
\hline 50$)$ & $.17 \%$ & .1 & $-30^{\mathrm{t} / \mathrm{x}}$ & $63^{x}$ & $\mathrm{i}$ & & & & & & & & \\
\hline NHel一 & -.03 & .33 & $.35 \%$ & $48 \%$ & $-.5 \%$ & 1 & & & & & & & \\
\hline$Z \triangle X Z \times$ & 04 & -177 & .11 & 03 & $-34^{2}$ & .10 & 1. & & & & & & \\
\hline MHS & .03 & -02 & $.118^{+2}$ & -1.5 &. .13 & 00 & -62 & l & & & & & \\
\hline $\mathrm{ROH}$ & -01 & .15 & .94 & -354 & $-.20 * *$ & (1) & -.14 & $.58 \%$ & 1 & & & & \\
\hline Wax & $24^{* * *}$ & $\cdots, 110$ & 25 ; & -.16 & -.13 & .06 & $.0 \%$ & $.56^{\text {* }}$ & 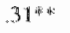 & 1 & & & \\
\hline ALI & $23^{2 \times}$ & -.98 & $16^{*}$ & .010 & .92 & -07 & -.10 & $6 \|^{* 4}$ & $360^{6 *}$ & $53^{n-8}$ & 1 & & \\
\hline $\mathrm{HARC}$ & $1 \%$ & -.04 & $19^{* k}$ & -87 & .03 & .08 & .13 & $.18^{*}$ & 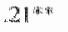 & $n$ & $15 \%$ & $\forall$ & \\
\hline CHDS & $1166^{*}$ & 12 & 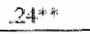 & -.00 & $\cdots 11$ & .68 & -.100 & 270 & $\| f^{*}$ & $.17^{6}$ & dor & $66^{* 16}$ & $!$ \\
\hline
\end{tabular}

* singnifican op $\mathrm{p}<0.01$ niveau (weezid dig)

* significan op $p<0.05$ nivean (tweezijdig). 


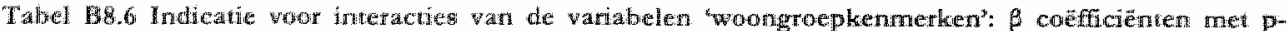
watrden uir de theresterandysen op de criteriunvariabelen personeelswisselingen (STAB, INFR en TOWG) met als woowpellers de woongroepkenmetken clustergrootte (CLUS), sociowoningen (SOC), groepwgrowte (NDEW) en zorgzwarte (ZOZW) en de interacties tussen de wrongroepkenmerhen (N) = $180 \mathrm{y}$.

\begin{tabular}{|c|c|c|c|}
\hline Voorepiatlers & critegiurs & $\beta$ & $p$ \\
\hline CHUS & \multirow[t]{4}{*}{$S T A B$} & -306 & .590 \\
\hline $8 O C$ & & .008 & .960 \\
\hline CLLSXSOC & & .473 & .473 \\
\hline$R^{2}=.0 d$ & & & \\
\hline CLUS & \multirow[t]{4}{*}{$S T^{*} A B$} & .179 & .479 \\
\hline NBEW & & .060 & .656 \\
\hline CLUSXMBIEW & & .018 & 933 \\
\hline$R^{2}=.03$ & & & \\
\hline CLUS & \multirow[t]{4}{*}{$S T A$} & .083 & .572 \\
\hline $202 W$ & & -102 & .388 \\
\hline CLUSN20ZW & & .113 & .519 \\
\hline$R^{2}=.03$ & & & \\
\hline $\mathrm{SOC}$ & \multirow[t]{4}{*}{ STAB } & .457 & .094 \\
\hline NBBEW & & .318 & .230 \\
\hline SOCXNBEW & & -.256 & .327 \\
\hline$R^{2}=.04$ & & & \\
\hline$S O C$ & \multirow[t]{4}{*}{$\$ T A B$} & .153 & .295 \\
\hline $202 W$ & & -019 & 939 \\
\hline $50 C \times 202 W$ & & .038 & .874 \\
\hline$R^{2}=03$ & & & \\
\hline NBEW & \multirow[t]{4}{*}{$S T A B$} & -114 & .400 \\
\hline ZOZW & & -866 & .388 \\
\hline NBGWX2OZW & & .750 & .454 \\
\hline$R^{2}=01$ & & & \\
\hline CLUS & \multirow[t]{4}{*}{ INI:R } & -1.323 & .014 \\
\hline $\mathrm{SOC}$ & & .125 & .423 \\
\hline CLUS $\times \$ O C$ & & 984 & .113 \\
\hline $\mathrm{R}^{2}=.15$ & & & \\
\hline CLUS & \multirow[t]{4}{*}{ INFR } & -.097 & .690 \\
\hline NBEW & & -.042 & .746 \\
\hline CLUSRNBEW & & -1.130 & .260 \\
\hline$R^{2}=.10$ & & & \\
\hline CLUS & \multirow[t]{4}{*}{ INFR } & $-n^{4} 44$ & .002 \\
\hline ZOZW & & -.284 & .013 \\
\hline CLUSX2OZW & & .237 & .158 \\
\hline$R^{2}=.11$ & & & \\
\hline $\mathrm{SOC}$ & \multirow[t]{4}{*}{ INFR } & -1.152 & .000 \\
\hline NBIE & & -1.104 & .000 \\
\hline SOCXNBEW & & 1.195 & .000 \\
\hline$R^{2}=.12$ & & & \\
\hline$\$ 00$ & \multirow[t]{4}{*}{ INFR } & .064 & .659 \\
\hline$\angle O Z \mathrm{WW}$ & & .044 & .861 \\
\hline$\$ 00 \times 2024$ & & -231 & .333 \\
\hline $1 k^{2}=.04$ & & & \\
\hline NBCW & \multirow[t]{4}{*}{ INFK } & .256 & .048 \\
\hline $702 \mathrm{~W}$ & & .272 & .246 \\
\hline NBEW $\times \angle O Z W$ & & -.527 & .048 \\
\hline $\mathbb{R}^{-6}=.05$ & & & \\
\hline ClLSS & \multirow[t]{4}{*}{ TOWG } & -.182 & .731 \\
\hline 500 & & -.019 & .904 \\
\hline CLSSSOC & & -215 & .725 \\
\hline$R^{3}=. L^{57}$ & & & \\
\hline CLOS & \multirow[t]{4}{*}{ TOWG } & -.055 & .812 \\
\hline NaEW & & .304 & .014 \\
\hline CLUSXNBEX & & -211 & .246 \\
\hline$R^{n}=.20$ & & & \\
\hline
\end{tabular}




\begin{tabular}{|c|c|c|c|}
\hline CLUS & \multirow[t]{4}{*}{ TOWG } & -.314 & 023 \\
\hline $20 Z W$ & & -.034 & .750 \\
\hline CLUSXZOZW & & -121 & .455 \\
\hline $\mathbb{R}^{2}=.18$ & & & \\
\hline soc & \multirow[t]{4}{*}{ TOWG } & -.888 & .000 \\
\hline NBEW & & -.440 & .072 \\
\hline SOCXNBEW & & .736 & .002 \\
\hline $\mathbb{R}^{2}=.19$ & & & \\
\hline soc & \multirow[t]{4}{*}{ TOWG } & -077 & .571 \\
\hline $202 W$ & & 336 & .145 \\
\hline SOCxzOZW & & -.577 & .010 \\
\hline$R^{2}=17$ & & & \\
\hline NBEW & \multirow[t]{4}{*}{ TOWG } & .311 & .014 \\
\hline ZOZW & & -.236 & .287 \\
\hline NBEWXZOZW & & .120 & .633 \\
\hline $\mathrm{R}^{2}=.14$ & & & \\
\hline
\end{tabular}

Noot De significante interactie-effecten zhjo vet gedrukt weergegeven. 


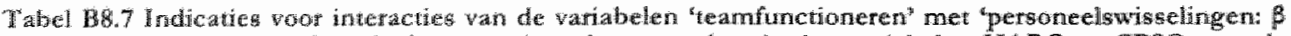

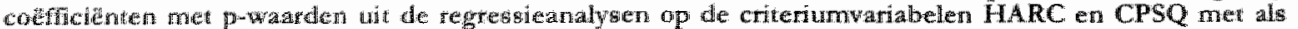
woorspeliers de teanvariabelen MAS. ROL, VER, AUT, de personeelswisselingmaten STAB, INFR en

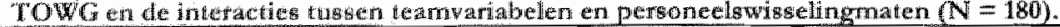

\begin{tabular}{|c|c|c|c|}
\hline Voonspellers & crientum & $\beta$ & $\mathrm{p}$ \\
\hline MAS & \multirow[t]{4}{*}{ HARC } & 0,25 & .326 \\
\hline $\mathrm{SU} A$ & & 0,46 & .657 \\
\hline MASxUIAB & & $-0,34$ & .750 \\
\hline $\mathrm{R}^{2}=.65$ & & & \\
\hline MASS & \multirow[t]{4}{*}{$\mathrm{CPSQ}$} & 0,79 & .001 \\
\hline$S T A B$ & & 2,37 & .018 \\
\hline MASXSTAB & & $-2,31$ & .026 \\
\hline$R^{2}=.12$ & & & \\
\hline MAS & \multirow[t]{4}{*}{ HARC } & 2,32 & .021 \\
\hline $\mathbb{N N} / \mathrm{K}$ & & $-0,05$ & .800 \\
\hline MASXNVR & & $0,0 \%$ & 946 \\
\hline $\mathrm{R}^{2}=.03$ & & & \\
\hline MAS & \multirow[t]{4}{*}{$\mathrm{CPSQ}$} & 0,26 & .000 \\
\hline SWR & & $\cdots, 0,07$ & .679 \\
\hline MASXINOR & & $-0,05$ & .793 \\
\hline $\mathbb{R}^{2}=.09$ & & & \\
\hline MAS & \multirow[t]{4}{*}{ HARC } & 0,14 & .078 \\
\hline "row & & 0,08 & .714 \\
\hline MASXJOWO & & 0,09 & .684 \\
\hline$R^{2}=.00$ & & & \\
\hline MAS & \multirow[t]{4}{*}{ CPSQ } & 0,24 & .002 \\
\hline TOWWG & & 0,29 & .180 \\
\hline MASXIOOWG & & $-0,10$ & .633 \\
\hline$k^{2}=.11$ & & & \\
\hline ROL & \multirow[t]{4}{*}{ HARC } & 0,51 & .022 \\
\hline STAB & & 1,64 & .124 \\
\hline $\mathrm{RO} \| \times \mathrm{ST}$ & & $-1,53$ & .158 \\
\hline $\mathrm{R}^{2}=.08$ & & & \\
\hline $\mathrm{ROL}$ & \multirow[t]{4}{*}{$\operatorname{CPSQ}$} & 0,66 & .004 \\
\hline$S 1 \mathrm{NB}$ & & 2,58 & .016 \\
\hline ROLXSTAB & & $-2,46$ & .023 \\
\hline $\mathrm{R}^{3}=.08$ & & & \\
\hline ROL & \multirow[t]{4}{*}{ HARC } & 0,18 & .186 \\
\hline INRR & & $-0,65$ & .677 \\
\hline ROLXINPR & & 0,59 & .712 \\
\hline $\mathbb{R}^{2}=.05$ & & & \\
\hline 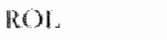 & \multirow[t]{4}{*}{ CPSQ } & 0,01 & .964 \\
\hline Mindil & & $-2,72$ & .080 \\
\hline RQHALIMGR & & $2,6 !$ & .098 \\
\hline$R^{2}=07$ & & & \\
\hline RQD & \multirow[t]{4}{*}{$\mathrm{HARC}$} & 0,01 & .566 \\
\hline $10 W 0$ & & $-1,02$ & .396 \\
\hline ROLXTONG & & 1,20 & .336 \\
\hline$x^{2}=.17$ & & & \\
\hline Rol. & \multirow[t]{4}{*}{ CPSQ } & 0,08 & 541 \\
\hline "Mowk. & & $-0,10$ & .931 \\
\hline ROI xONG & & 0,32 & .790 \\
\hline $\mathrm{R}^{2}=07$ & & & \\
\hline VGR & \multirow[t]{4}{*}{ HARC } & 0.10 & .615 \\
\hline STA & & 0,32 & .549 \\
\hline VERXSIAB & & -0.21 & .718 \\
\hline $\mathrm{R}^{2}=02$ & & & \\
\hline$V E R$ & \multirow[t]{4}{*}{ CPSQ } & 0,12 & .525 \\
\hline $51 \div \mathrm{MB}$ & & 0,05 & .903 \\
\hline VERxSTAB & & 0,7 & .905 \\
\hline$R=.014$ & & & \\
\hline TIR & HARC & 0,02 & .887 \\
\hline
\end{tabular}




\begin{tabular}{|c|c|c|c|}
\hline $\begin{array}{l}\text { TNER } \\
\text { VERXINER } \\
\mathrm{R}^{2}=.01\end{array}$ & & $\begin{array}{r}-0,27 \\
0,24\end{array}$ & $\begin{array}{l}.726 \\
.756\end{array}$ \\
\hline VER & $\mathrm{CPSQ}$ & 0,22 & 131 \\
\hline INER & & 0,29 & .706 \\
\hline $\begin{array}{l}\text { VERWMFR } \\
\mathbb{R}^{2}=.04\end{array}$ & & $-0,39$ & .605 \\
\hline VER & MARC & 0,03 & .845 \\
\hline Towo & & 0,28 & .709 \\
\hline $\begin{array}{l}\text { VERTTOWO } \\
R^{2}=.04\end{array}$ & & $-0,09$ & .906 \\
\hline WER & cesa & 0.11 & 391 \\
\hline TOWG & & 0,21 & .770 \\
\hline $\begin{array}{l}\text { VERTIOWG } \\
\mathrm{R}^{2}=07\end{array}$ & & $-0,01$ & .994 \\
\hline $\mathrm{ABT}$ & $\mathrm{H}_{\mathrm{ARC}} \mathrm{RC}$ & 0,28 & .182 \\
\hline $\operatorname{STAB}$ & & 0,64 & 343 \\
\hline AUTXSTAB & & $-0,59$ & .428 \\
\hline $\mathrm{R}^{2}=.04$ & & & \\
\hline AUT & CPSQ & 0,42 & 046 \\
\hline STAB & & 1,01 & .28 \\
\hline $\begin{array}{l}\text { AUTxSTAB } \\
R^{2}=.06\end{array}$ & & $-0,99$ & .178 \\
\hline AUT & HARC & 0,02 & .903 \\
\hline NNF & & $-1,06$ & .196 \\
\hline AUTKINTR & & 1.03 & .206 \\
\hline$R^{2}=.03$ & & & \\
\hline AUT" & CPSQ & 0,22 & .131 \\
\hline MNER & & 0,29 & .706 \\
\hline AUTXINER & & -0.39 & .605 \\
\hline $\mathbb{R}^{2}=.04$ & & & \\
\hline AUT & HARC & $0,1.3$ & .287 \\
\hline TOWG & & 0,23 & .746 \\
\hline AUTXTOWG & & $-0,54$ & 940 \\
\hline$R^{2}=.04$ & & & \\
\hline AUT & CPSQ & 0,17 & .140 \\
\hline TOWG & & 0,42 & .540 \\
\hline AUTXTOWG & & $-2,17$ & 760 \\
\hline $\mathrm{k}=.08$ & & & \\
\hline
\end{tabular}

Now. De significante moderatoneffecten zijo ver gedruke weorgegeven. 


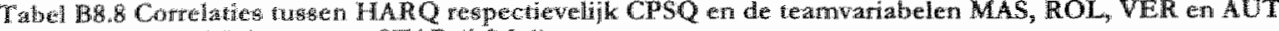
binnen wat quartielniveans van $S \mathrm{~T}^{\prime} \mathrm{AB}(1,2,3,4)$

\begin{tabular}{|c|c|c|c|c|c|c|c|c|}
\hline & \multicolumn{2}{|c|}{ 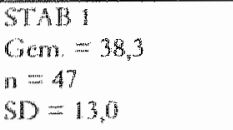 } & \multicolumn{2}{|c|}{$\begin{array}{l}5 T A B 2 \\
\operatorname{Gcm}=60,3 \\
\operatorname{si}=43 \\
\mathrm{SD}=4,2\end{array}$} & \multicolumn{2}{|c|}{$\begin{array}{l}5 \mathrm{SAB} 3 \\
\mathrm{Sem}=75,9 \\
\mathrm{n}=46 \\
\mathrm{SD}=4,4\end{array}$} & \multicolumn{2}{|c|}{$\begin{array}{l}\text { STAB } 4 \\
\text { Gem. }=92,3 \\
n=44 \\
\mathrm{SD}=6,8\end{array}$} \\
\hline & HAPQ & CPSO & $\mathrm{HARQ}$ & CPSQ & HARQ & CPSQ & HARQ & CPSQ \\
\hline$M A s$ & .23 & $.45^{m-6}$ & 12 & .24 & 19 & 20 & .17 & .03 \\
\hline ROI. & .29 & $31 \%$ & .20 & 14 & $.33^{\text {nt }}$ & .23 & .03 & -.06 \\
\hline VER & .15 & .20 & -.11 & .14 & .07 & .08 & -03 & .15 \\
\hline AUT" & 24 & 26 & .17 & .18 & .01 & .01 & .20 & 26 \\
\hline
\end{tabular}

Tubel 18.9 Correlaties tussen HARQ respectievelijk CPSQ en de teamvariabelen MAS, FOL, VER en AUT binnen vier quarticlniveaus van. INTR $(1,2,3,4)$

\begin{tabular}{|c|c|c|c|c|c|c|c|c|}
\hline & \multicolumn{2}{|c|}{$\begin{array}{l}\text { MWR I } \\
G \mathrm{~m}=17.9 \\
\mathrm{n}=43 \\
\mathrm{SD}=10,3\end{array}$} & \multicolumn{2}{|c|}{$\begin{array}{l}\text { INFI } 2 \\
\text { Gem }=43,3 \\
\mathrm{n}=47 \\
\mathrm{SD}=7,4\end{array}$} & \multicolumn{2}{|c|}{$\begin{array}{l}\mathrm{NFR} \\
\mathrm{Gem}=68,1 \\
\mathrm{n}=46 \\
\mathrm{SD}=7,9\end{array}$} & \multicolumn{2}{|c|}{$\begin{array}{l}\text { TNFR } 4 \\
\text { Gem. }=128,9 \\
\mathrm{n}=44 \\
\mathrm{SD}=52,3\end{array}$} \\
\hline & HARQ & $\cos 2$ & HARQ & CPSQ & HARQ & CPSQ & MARQ & CPSQ \\
\hline $\mathrm{MAS}$ & .11 & 14 & .27 & $.34^{\pi}$ & .26 & .15 & .13 & .40 \\
\hline $\mathrm{ROI}$ & .20 & .17 & .09 & .08 & .17 & .09 & $.37 \%$ & $46^{*: a}$ \\
\hline$V \ln R$ & .00 & .26 & .13 & .16 & .06 & .07 & .04 & 17 \\
\hline AUT & .12 & 20 & .17 & .21 & 01 & -1.12 & 27 & $40 \%$ \\
\hline
\end{tabular}

Tabeil B8.10 Correlaties nusen HARQ respectievelijk CPSQ en de teamvariabelen MAS, ROL, VER en AUT binnen vier guartielniweaus wan TOWG $(1,2,3,4)$

\begin{tabular}{|c|c|c|c|c|c|c|c|c|}
\hline & \multicolumn{2}{|c|}{$\begin{array}{l}\text { TOWG } 1 \\
\text { Gem }=13.7 \\
\mathbb{N}=44 \\
\mathrm{SD}=4.5\end{array}$} & \multicolumn{2}{|c|}{$\begin{array}{l}\text { HOWG } 2 \\
\text { Genn. }=29,0 \\
N=45 \\
S D=4,3\end{array}$} & \multicolumn{2}{|c|}{$\begin{array}{l}\text { TOWG } \\
\text { Gem. }=47,2 \\
N=45 \\
S D=7,2\end{array}$} & \multicolumn{2}{|c|}{$\begin{array}{l}\text { TON/G } \\
\text { Gem }=83,1 \\
N=45 \\
S D=20,9\end{array}$} \\
\hline & HARQ & CPSQ & HARQ & $\operatorname{cPs} Q$ & HARQ & CPSQ & $\mathrm{HARQ}$ & $\operatorname{CPSQ}$ \\
\hline $\mathrm{MAS}$ & $32^{k}$ & $.36^{*}$ & .03 & .12 & -01 & 17 & .26 & 20 \\
\hline $\mathrm{ROH}^{\circ}$ & .10 & .03 & .19 & 18 & .03 & 10 & $.36^{*}$ & .18 \\
\hline VER & .69 & .16 & -.08 & -.03 & .03 & 15 & .08 & 27 \\
\hline AUT & .26 & .22 & -.03 & .03 & .04 & 20 & .25 & .18 \\
\hline
\end{tabular}

Tabel B8.LI Decompositie van de variantie in HARC en CPSQ: percentage variantie op het niveau vath ceants chusters en instellingen met bijhorende $\mathrm{p}$-watarde.

Varibiliotion

$1 \mathrm{ARC}$

Percontage varinncic op nivenu van:
Team:
Clusters
$9210.009 *$
$03(0.71)$
Instellingen
$05(0.10)$

\begin{tabular}{|c|c|}
\hline \multicolumn{2}{|c|}{$\cos$} \\
\hline Percentage varian & \\
\hline Teams & $86(0.00) \times$ \\
\hline Clusters & $09(0.22)$ \\
\hline Instellingen & $05 \quad(0.16)$ \\
\hline
\end{tabular}


Tabel B8.12 Regressie analyse ten behoeve van de pax analyse op criterium MARC $(\mathrm{N}=180)$

\begin{tabular}{|c|c|c|c|}
\hline Vonospelleti & Criterium & $B(\mathrm{p}$ & $\mathrm{R}^{2}$ \\
\hline $\mathrm{MAS}$ & HARC & $.132(256)$ & \\
\hline $\mathrm{ROL}$ & & $.117(.246)$ & \\
\hline MER & & $-122(.216)$ & \\
\hline AUT & & $.044(.660)$ & \\
\hline STAB & & $.098(.259)$ & \\
\hline INFR & & $-.044(.006)$ & \\
\hline TOWG & & $.124(168)$ & \\
\hline CLUS & & $.046(.695)$ & \\
\hline $\mathrm{SOC}$ & & $.051(665)$ & \\
\hline NBEXW & & $.097(294)$ & \\
\hline $2 O Z W$ & & $-092(283)$ & \\
\hline R: Totaal & & & 107 \\
\hline
\end{tabular}

Tabel B8.13 Regressic analyses ten behoeve van de pad analyse op criterium CPSQ (N = 180)

\begin{tabular}{|c|c|c|c|}
\hline Voorspeller & Criterium & $\beta(p)$ & $\mathrm{R}^{2}$ \\
\hline$M A S^{*}$ & \multirow[t]{12}{*}{ CPSQ } & $.251(.028)$ & \\
\hline $\mathrm{ROL}$ & & $.000(927)$ & \\
\hline$V E R$ & & $-.050(.604)$ & \\
\hline AUT & & $-005(961)$ & \\
\hline STAB & & $.101(235)$ & \\
\hline TNPR & & $-.049(.562)$ & \\
\hline TOWO* & & $.197(.026)$ & \\
\hline CLUS: & & $.213(.067)$ & \\
\hline 500 & & $-185(110)$ & \\
\hline NBEW & & $028(758)$ & \\
\hline $207 W$ & & $-055(509)$ & \\
\hline $\mathrm{R}^{2}$ Totalal & & & 152 \\
\hline $5 \Gamma A B$ & \multirow[t]{7}{*}{ MAS } & $.012(.890)$ & \\
\hline TNFR & & $-045(600)$ & \\
\hline $\mathrm{TOWG}^{*}$ & & $.67(056)$ & \\
\hline CLUS & & $-177(.532)$ & \\
\hline $50 \mathrm{c}$ & & $-.125(200)$ & \\
\hline NBEE W & & $-155(093)$ & \\
\hline$\angle 0, W$ & & $.036(672)$ & \\
\hline CLUS & \multirow[t]{4}{*}{$\mathrm{TOWO}$} & $-.247(012)$ & \\
\hline 500 & & $-087(399)$ & \\
\hline NBEW & & $.190(1021)$ & \\
\hline ZOZW & & $-.144(055)$ & \\
\hline
\end{tabular}

(1) matginad sgyngificant 
Binagen

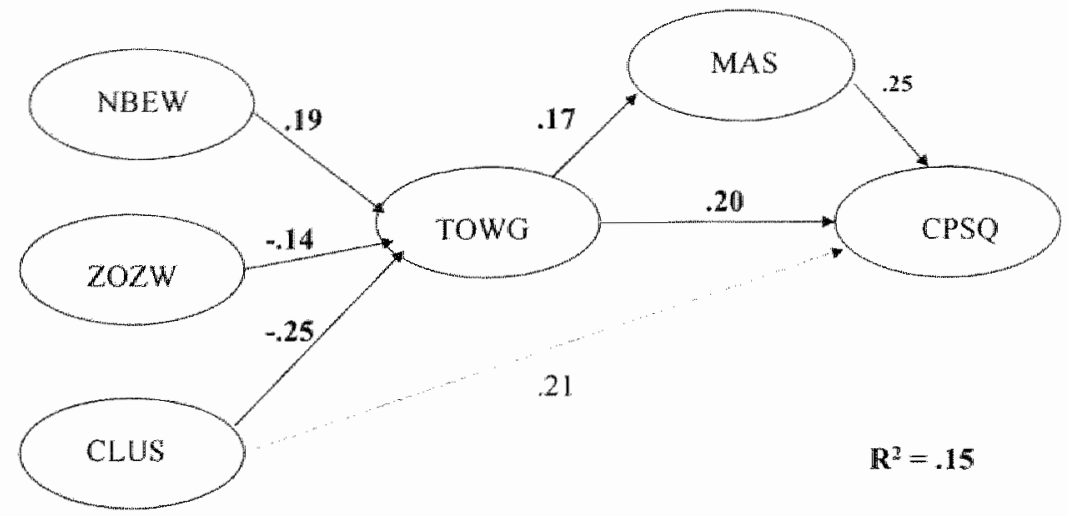

Figuur B8.4 Pad diagram met voorspellers van door familie ervaren relationele kwaliteit wan begeleiding (CPSQ) met vermelding valn het marginaal signifante pad CLUS-CPSQ 
Dankwoord 

Ook het maken van een proefschrift kan niet anders worden begrepen dan wanuit de interactie van de promovendus met zijn omgeving. Die levert daarbij niet alleen uitdagingen en obstakels, maar ook de voorwaarden en de steun om dit intensieve leetproces - want zo het ik het ervaren - tot een goed einde te brengen. Het inhoudelijke verslag van dit leerproces wordt uitgebreid in dit boekwerk beschreven. Het persoonlijke verslag is minstens zo boeiend, maar beperk ik hier tor de essentie: mijn respect on dankbaarheid voor de mensen in mijn ongeving zonder wie dit proefschrift niet mogelijk was geweest.

Van Ad van Gennep heb ik geleetd - en na veel discussie ook ruiterlijk toegegeven - dat het gelijk van de manager niet van dezelfde orde is als het gelijk van de onderzoeker. Van probleemstelling naar vraagstelling, naar onderzoeksvragen binnen een theoretisch kader, naar dataverzameling en uiteindelijk naar interptetatie van resultaten in functie van al het voorafgaande en in de goede volgorde, is een discipline die ik me met veel herschrijven en herwerken heb moeten eigen maken. Tijdens dat proces ben ik enthousiast vele zijpaden ingestagen - want in de praktijk etvaart de manager dagelijks hoe 'alles met alles' samenhangt, en dat wil hij ook bij een wetenschappelijk werkstuk demonstreren - maar ik ben ook weer op mijn stappen moeten terugketen, om tot een coherente behandeling van de probleemstelling te komen. Ad is daarbij een didactisch leidsman geweest die mij met het geduld van een goed onderwijzer heeft begeleid. Ik ben hem zeer erkentelijk voor deze 'opleiding'. Vanwege zijn brede eruditie heb ik het als een voorrecht beschouwd met Ad als promotor te mogen werken. Daarmee kon ik het onderzoek in een rumer kader situeren en mede daardoor zijn toch enkele zijpaden in deze studie behouden gebleven.

Het doen van onderzoek is voot iemand die in de praktijk van een zorginstelling werkt alleen mogelijk als daartoe goede voorwaarden aanwezig zijn. Bij de stichring Sint Anna heb ik van meet af aan deze voorwaarden aangetroffen. $1 \mathrm{k}$ wil in dit verband drie personen met name noemen. In de eerst plaats dhr. Getard Heiligers. Hij heeft reeds in het begin van de jaren zeventig het belang van reflectie en van wetenschappelijk onderzoek voor de ontwikkeling van de zorg aan mensen met verstandelijke beperkingen beklemtoond en heeft daartoc binnen de organisatic kansen geschapen. De vroege samenwerking met de 'Rijksuniversiteit Limburg' was daarvan één element. Een ander element was het publiceren van de vruchten van bezinning en van studies van medewerkers in de door hem in het leven geroepen reeks Anna-Cahiers. Het is ook zijn verdienste dat de SWIHC en de bijzondere leerstoel - de Gouverneur Kremers Leerstoel - bij de Universiteit Maastricht tot stand zijn gekomen. Ik beschouw het als een voorrecht om daaraan samen met hem te hebben mogen werken. Ik noem in de tweede plaats drs. Gerard van der Velde. Vanuit zijn eerdere functies als faculteitsdirecteur in Nijmegen en later als directeur van het Academisch Ziekenhuis Maastrich had hij grote affiniteit met onderzoek. Hij heeft binnen de stichting Sint Anna de onderzoeksmogelijkheden verdet uitgebouwd, met name door het in het leven roepen van cen stafgroep 'Onderzoek en Ontwikkeling'. Ook heeft hiy de samenwerking met universiteiten 
uitgebreid waardoor in de jaren negentig meerder afstudeerscripties maar ook een zestal proefschriften - waaronder mijn eigen promotieonderzoek - hun oorsprong hebben gevonden in de zorgpraktijk van de stichting Sint Anna. Ik noem in de derde plaats dhr. Chrik Diemel, MPH, die vanaf 2000 deze lijn heeft doorgezet en een structurele verankering van de samenwerking tussen zorgveld en universiteit ondersteunde. Daardoor participeent de stichting Sint Anna in het Gouverneur Kremers Centrum (GKC) waatin ook de zorgorganisaties Pepijn en Paulus, Vizier, Daelzicht, Radar en de Plaatse deelnemen. Er is met het GKC een succesvolle formule gevonden die thans onder leiding wan prof. dr. P. Curfs verder wordt ontwikkeld in de tichting van volwaardige academisering van de zorg voor mensen met verstandelijke beperkingen. Mijn participatie in het GKC en vooral de samenwerking met en wriendschap wan collega's zoals dr. Henny van Schrojenstein Lantman-de Valk, dr. Marian Maaskant en dr. Brenda Frederiks ervaar ik als positief en stimulerend.

Mijn 'omschakeling' van managementwerk naar wetenschappelijk werk werd vanaf 2000 zeer vergemakkelijkt cloor het wetenschappelijke èn het collegiale klimaat dat ik aantrof bij BEOZ. Ik ben prof. dr. Wim Groot en het bestuur van de capaciteitsgroep zeer erkentelijk voor de kans die mij werd geboden mijn onderzoek binnen deze groep uit te voeren. Aan deze positieve ervaring hebben alle BEOZ collega's zonder uitzondering bijgedtagen maar ik noem hier toch in het bijzonder drs. André Meijer die mij in her UM onderwijs introduceerde en mij de weg wees naat wat de wetenschap te bieden heeft op het tertein van strategisch management en zorgmarketing. Tk noem ook dr. Gladys Tummers bij wie ik op de meest onmogelijke momenten kon binnenvallen om mijn kennis van statistiek op te frissen of bij te spijkeren; menige statistische procedure hebben wij in de wandelgangen peripatetisch doorgeëxerceerd.

Er zijn vele mensen die hebben bijgedragen aan het tot stand komen van mijn promotieonderzoek. Ik ben de méér dan tweeduizend respondenten van mijn vragenlijsten dankbaar voor hun vettrouwen en hun medewerking; medewerkers en familie van bewoners van de betrokken instellingen. De directies van deze instellingen ben ik zeer erkentelijk voor hun bereidheid en belangstelling om te participeren in mijn onderzoek, temeer ondat de dataverzameling platsvond in een tijd dat ook Zon-Mw onderzoekers valk grote moeite hadden medewerking van instellingen te verktrigen en te behouden. In het bijzonder waardeer ik het dat de instellingen de dataverzameling hebben ondersteund door het verzorgen van mailings en het beschikbaar stellen van tijd van medewerkers voor het leveren van de interne gegevens.

Tk ben mevr. Marianne Werts en mevr. Annemick Vogels van de Bibliotheek en Documentatievoorziening van de stichting Sint Anna dankbaar voor hun intensieve speurwerk en het opvragen van boeken en artikelen ten behoeve van de literatuurstudie. Dankzij hun ervating en hun uitgebreide netwerk (in binnen-en buitenland) bleck hun slaagkans daarbij verrassend hoog. De dataverwerking van 
mijn promotieonderzoek is vlot kunnen verlopen dank zij de Office-skills wan mevr. Eveline Briels-Timmer. Zij verzorgde de lay-out en de productie van de vragenlijsten en bouwde de Access invoermodule waamee alle ruwe data met een hoge betrouwbaar konden worden ingevoerd. Ook assisteerde ziij met de voorbereidingen van de SPSS-bestanden. Dr. Math Candel ben ik erkentelijk voor zijn statistische adviezen, evenals dr. Hans Bosma voor zijn hulp bij de multilevel analyse waarmee de significantie van de hiërarchische datastructuur werd onderzocht. Mevr. Isel van Noppen wil ik graag bedanken voor de secretariële ondersteuning en de werzorging van de opmaak van het manuscript. Haar praktische instelling, ervaring en kennis van het universitaire bedrijf hebben mij veel tijd bespaatd en het vertrouwen gegeren dat ik het manuscript met een gerust hart uit handen kon geven.

Ik ben de leden van de beoordelingscommissie zeer erkentelijk voor hun bereidheid mijn manuscript te bestuderen en voor hun betrokkenheid bij de beoordeling: prof. dr. Wim Groot, prof. dr. Bert Aldenkamp en itk noem in het bijzonder prof. dr. Bea Maes omdat zij in deze commissie 'mijn' Alma Mater te Leuven vertegenwoordigde.

Ten slotte bedank ik collega's en familie voor hun morele steun en ook voor het geduld dat zij opbrachten tijdens de vele jaren die dit promotieproject duurde. $1 \mathrm{k}$ realiseet mij dat het inderdaad moeite moet hebben gekost om te begrijpen hoe de 'bijna klaar' fase van dit proefschrift zo lang kon duren. Ik realiseer me ook dat het spreekwoord 'men is nooit te oud om te leren' tot bedenkingen moet hebben geleid bij mijn kinderen, Monique en Eric, die nu in hun eigen levensfase juist proberen het leren zo snel mogelijk achter zich te krijgen. Een $50+$ vader die nog steeds met de neus in de boeken zit en voortdurend met huiswerk bezig is baart vanuit dat perspectief enige zorg. Heel in het bijzonder dank ik mijn vrouw Corrie voor de ruimte en de ondersteuning die ik al die jaren van haar heb mogen ervaren. Zij heeft al die tijd veel begrip en geduld opgebracht voor de onderneming die ik me had voorgenomen en daaraan haar eigen bijdrage geleverd. Zaken waarvoor ik thuis minder tijd nam of minder oog had bleven daardoor toch op de rails dank zij haar continue zorg. 



\section{Curriculum Vitae}



Wil Buntinx werd geboren op 21 juni 1947 te Hasselt (België). Hij beliaalde het diploma 'Latijn-Griekse Humaniora' in 1965 aan het Sint Josefscollege te Hasselt waarna hij Psychologie ging studeren aan de Katholieke Universiteit (K.U.) te Leuven. Hier behaalde hij in 1970 het diploma 'met onderscheiding'. Van 1975 tot 1977 volgde hij de postdoctorale opleiding gedragstherapie an de Faculteit der Geneeskunde van de K.U. te Leuven. Hij is ingeschreven in het $\mathbb{B I G}$-register Gezondheidszorgpsycholoog.

Na zijn militaire dienst als officier bij het Selectie- en Rekruteringscentrum te Brussel kwam hij in 1972 in dienst bij de stichting Sint Anna te Heel. Hier werkte hij als begeleidend psycholoog van de "kinderpaviljoens" en als docent psychopathologie aan de Z-opleiding. Van 1975 tot 1979 was hij daarnaast deeltijds in detachering werkzaam als wetenschappelijk medewerker bij de 'Rijksuniversiteit Limburg' (capaciteitsgroep Sociale Psychiatrie, prof. Dr. M. Romme) belast met onderzoek op het gebied van kwaliteit van zorg, ter woorbereiding van de voorziening Maasveld te Maastricht. In 1978 werd hij als coördinerend staflid voor de geplande Maastrichtse vootziening opgenomen in de directie van de stichting Sint Anna. In 1980 werd hij benoemd tot directeur zorgverlening bij Huize Op de Bies te Schimmert. Van 1984 tot 1991 was hij directeur zorgverlening van Maasveld te Maastricht en vervolgens vervulde hij dezelfde functie van 1991 tot 1994 in Sint Anna te Heel. Van 1994 tot 2000 coördineerde hij als directeur onderroek en ontwikkeling het onderzoeks- en kwaliteitsbeleid van de stichting Sint Anna alsmede de implementatie van nieuwe wetgeving. Van 1991 tot 2000 was hij eveneens plaatsvervangend algemeen directeur van de stichting Sint Anna.

In 2001 volgden een honoraire aanstelling als onderzoeker bij de Faculteit der Gezondheidswetenschappen van de Universiteit Maastricht en detachering als universitair docent bij de capaciteitsgroep Beleid, Economie en Organisatie van de Zorg. Hij is eveneens verbonden aan het Gouventneur Kieners Centrum, een samenwerkingsverband tussen Limburgse zorginstellingen en universitaire capaciteitsgroepen.

Wil Buntinx is lid van het NGBZ (Vereniging voor deskundigheidsbevordering in de zorg voor mensen met verstandelijke beperkingen) waarvan hij van 1991 tot 1998 voorzitter was. Sedert 1992 is hij lid van de American Association on Menal Retardation (AAMR) waar hij als voorzitter van de Itoremational Activities Committee de Europese inbreng in AAMR-conferenties organisecte. Sedert 1997 makt hij deel uit van het AAMR Committee on Terminology and Classification dat in 2002 onder leiding van prof. dr. R. Luckasson de $10^{\text {lk }}$ editie van het internationale handboek 'Mental Retardation' publiceerde. Hij is lid van de International Association for the Scientific Study of Intellectual Disability (IASSID). Wil Buntinx is medeoprichter (1988) en secretaris van de Sticlring Wetenschappelijk Instituut voor mensen met een verstandelijke handicap (SW/HC) die als rechtsdrager optreedt van bijzondere leerstoelen op het gebied van zorg aan mensen met verstandelijke beperkingen. In de periode 1995-2004 makte hij deel 
Lit van de programmacommissie 'Kwaliteit van Zorgonderzoek' (NWO) respectievelijk van de werkgroep 'Innovatie zorg voor mensen met een verstandelike handicap' (Zon-Mw). Hij maakt thans deel uit van de stuurgroep van het Landelijk Kennisnetwerk Gehandicaptenzorg (LKNG) en is sedert 1999 lid van de Provinciale Raad voor de Volksgezondheid Limburg.

Wil Buntinx is actief in de organisatie van symposia en conferenties in NGBZ-, AAMR-en IASSID-werband en geeft bij die gelegenheden ook presentaties en workshops, in het bijzonder over het AAMR ondersteuningsmodel voor mensen met verstandelijke beperkingen, de 'Support Intensity Scale' en kwaliteitszorg. In 2003 en 2004 werden op uitnodiging ook workshops gegeven aan de Université de Lille-1 (Frankrijk) en cle Université de Québec à Rimouski (Canada).

Hij is (mede)redacteur van diverse vakboeken en auteur van een groot aantal artikelen in zowel vak- als wetenschappelijke tijdschriften. Wil Buntinx is hoofdredacteur van het Nederlands Tijdschrift voor de Zorg aan mensen met verstandelijke beperkingen en lid van de redactieraad van Markant en het Handboek Mogelijiktheden (Elsevier).

In mei 2004 werd hij doot de AAMR benoemd tot 'Fellow of the American Association on Mental Retardation'. 
Si quis, tota dies carrens, penvenit ad wesperam, satis est.

Francesco Petrarca 